Andrews University

Digital Commons @ Andrews University

\title{
A Critical Evaluation of John Hick's Religious Pluralism in Light of His Eschatological Model
}

Haejong Je

Andrews University

Follow this and additional works at: https://digitalcommons.andrews.edu/dissertations

Part of the Philosophy Commons, and the Religious Thought, Theology and Philosophy of Religion Commons

\section{Recommended Citation}

Je, Haejong, "A Critical Evaluation of John Hick's Religious Pluralism in Light of His Eschatological Model" (2009). Dissertations. 70.

https://digitalcommons.andrews.edu/dissertations/70

https://dx.doi.org/10.32597/dissertations/70

This Dissertation is brought to you for free and open access by the Graduate Research at Digital Commons @ Andrews University. It has been accepted for inclusion in Dissertations by an authorized administrator of Digital Commons@ Andrews University. For more information, please contact repository@andrews.edu. 


\section{ABSTRACT}

\section{A CRITICAL EVALUATION OF JOHN HICK'S \\ RELIGIOUS PLURALISM IN LIGHT OF HIS ESCHATOLOGICAL \\ MODEL}

by

Haejong Je

Adviser: John T. Baldwin 


\title{
ABSTRACT OF GRADUATE STUDENT RESEARCH
}

\author{
Dissertation
}

\author{
Andrews University
}

Seventh-day Adventist Theological Seminary

\section{Title: A CRITICAL EVALUATION OF JOHN HICK’S RELIGIOUS PLURALISM IN LIGHT OF HIS ESCHATOLOGICAL MODEL}

Name of researcher: Haejong Je

Name and degree of faculty adviser: John T. Baldwin, Ph.D.

Date approved: April 2009

Introduction to the Problem

The philosophy of John Hick, who is famous for his religious pluralism, has received vigorous study in terms of its epistemology, authority, the concept of God, and Christology. However, less attention has been given to his pareschatology. As explained below, initial investigation shows that there is a need for in-depth study of Hick's religious philosophy in this area.

\section{The Problem}

Based upon preliminary research, Hick’s religious pluralism seems to reveal a critical problem with external correspondency, as follows. His pareschatology, which is an attempt to accept all eschatologies of major world religions as valid, may as a consequence tend to invalidate them all in the end. Moreover, other factors may indicate 
the presence of inconsistencies in Hick's pareschatological model, which may reflect upon the adequacy of his overall model of religious pluralism.

The Purpose

The purpose of this dissertation is to address and critically evaluate the external correspondency and internal consistency of Hick's eschatological model, which may provide the basis for a critical evaluation of his religious pluralism as a whole. The evaluation of John Hick's religious pluralism in light of his pareschatology will be accomplished through the lenses of the correspondence and coherence theories of truth.

\section{Conclusions}

Hick's pareschatology, as discussed in detail in chapters 4 and 5, and summarized in chapter 6, is open to various criticisms when judged by correspondence and coherence theories of truth. From my research of Hick's pareschatology, I uncover and present reasons which back twenty criticisms of Hick’s concept of pareschatology. Based upon these twenty criticisms, the first general conclusion of my dissertation is that Hick's notion of pareschatology does not show sufficient internal coherence, and it is also not fully coherent with his pluralistic model of world religions. The second general conclusion is that there is lack of external correspondence with the noumenal Real and with the phenomenal pareschatological manifestations of religious experiences in particular religions. As a result, questions may be raised whether his pareschatological model can be regarded as a convincing theological philosophical scientific construct. These considerations also have important implications for Hick’s religious pluralism, which lead to the final conclusion of my dissertation. I find Hick's religious pluralism as a whole to be weakened by the problematic condition of his pareschatology. 


\title{
Andrews University
}

Seventh-day Adventist Theological Seminary

\section{A CRITICAL EVALUATION OF JOHN HICK'S RELIGIOUS PLURALISM IN LIGHT OF HIS ESCHATOLOGICAL MODEL}

\author{
A Dissertation \\ Presented in Partial Fulfillment \\ of the Requirements for the Degree \\ Doctor of Philosophy
}

by

Haejong Je

April 2009 
(C) Copyright by Haejong Je 2009

All Rights Reserved 


\title{
A CRITICAL EVALUATION OF JOHN HICK'S RELIGIOUS PLURALISM IN LIGHT OF HIS ESCHATOLOGICAL MODEL
}

\author{
A dissertation \\ presented in partial fulfillment \\ of the requirements for the degree \\ Doctor of Philosophy
}

by

Haejong Je

APPROVAL BY THE COMMITTEE:

Faculty Adviser, John T. Baldwin

Professor of Systematic Theology

Fernando L. Canale

Professor of Theology and Philosophy

Miroslav M. Kiš

Professor of Ethics

Chair, Theology and Christian Philosophy
Director of Ph.D./Th.D. Program Roy E. Gane

Dean, SDA Theological Seminary

Denis Fortin 


\section{TABLE OF CONTENTS}

\section{Chapter}

I. INTRODUCTION

Background of the Problem

Statement of the Problem ……................................................................... 7

Purpose of the Research …….............................................................. 8

Justification for the Research ………................................................. 8

Scope and Delimitations

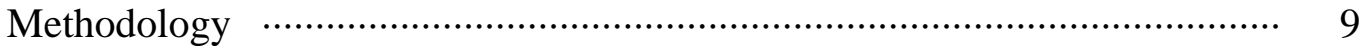

II. JOHN HICK, THEOLOGIAN AND PHILOSOPHER ……....................... 12

Introduction

Biographical Background of Hick

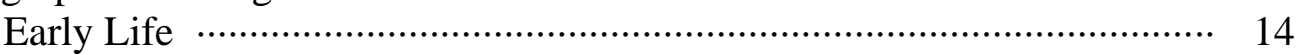

Family Background and Childhood ………............................... 14

Education …........................................................................... 15

Religious Experiences

Publications ………............................................................ 21

Teaching Career ………...................................................... 25

Cornell University (1956-1959) …………………………….... 26

Princeton Theological Seminary (1959-1964) ……......................... 28

Cambridge University (1963-1967) ………................................... 31

Birmingham University (1967-1982) …….................................... 32

Claremont Graduate University (1978-1992) ……..................... 37

Personal Journey: From Theologian to Philosopher …............................. 40

Early Hick: The Theologian

The Evangelical Period (to 1940s) ……........................................... 41

Philosophical Turn to Pluralistic Thinking (1950-1960s) …........... 43

Later Hick: The Philosopher ………………................................ 47

Pluralist from Christian Perspective (1970s) ................................ 48

Pluralist from Philosophical Perspective (1980s-Present) …............ 50

Hick’s Starting Point: Views of Scripture …….................................... 53

Theological Presuppositions …………….................................. 53

Some Examples of Interpretation …………................................. 57

The Creation Story of Genesis ……............................................ 57 
Accounts of Jesus in the Four Gospels …………………………… 58

Mythological Understanding of the Bible ………………..................... 60

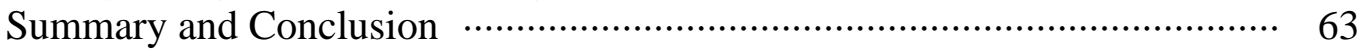

Life Experience …………………………………………………. 63

Mythological Interpretation of the Bible ……………………………. 64

III. AN ANALYSIS OF HICK’S PLURALISTIC HYPOTHESIS …………….... 66

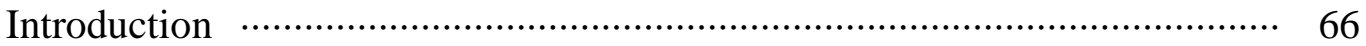

Hick’s “Copernican Revolution” and Subsequent Kantian Shift ……….... 67

Hick's Early Theocentric Model of Religions ………………………...... 69

Hick's Later Shift to Kantian Model of Religions ………...................... 72

Implications for Christology ………............................................... 75

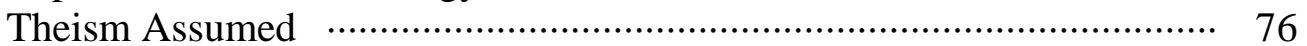

Truth Claims ………………………………………………………. 7

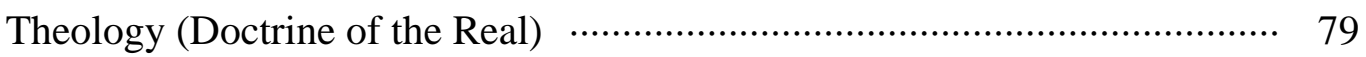

The Concept of the Real ………………………............................ 80

The Distinction between Noumenon and Phenomenon ……………....... 83

The Possibility of Knowledge of the Real …………............................... 90

The Linkage between the Noumenal Real and the Phenomenal Real ….. 95

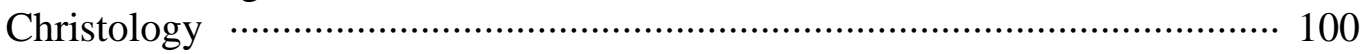

From Christocentrism to Theocentrism ……………............................ 101

An Inspirational Christology ……………………………………..... 106

Mythological Understanding of Christ …………………..................... 110

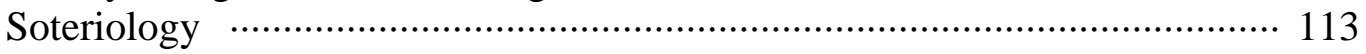

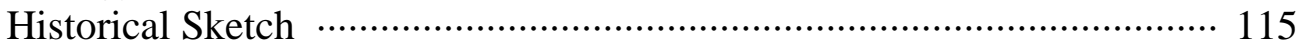

Salvation as Human Transformation …………….............................. 117

Universal Salvation ………………………………………………... 120

Soteriology and Ethics ……………………………………………… 122

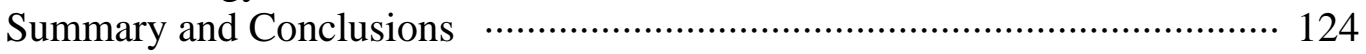

IV. HICK'S ESCHATOLOGICAL MODEL_PARESCHATOLOGY …………... 129

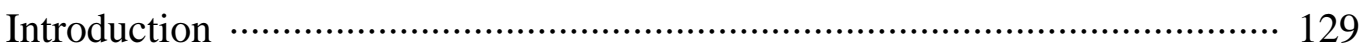

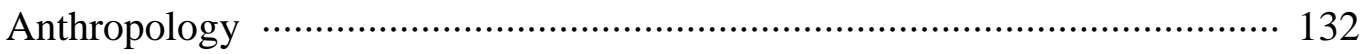

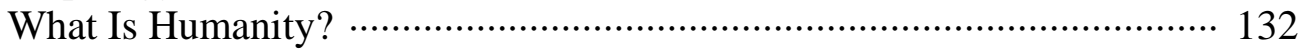

Dichotomous View of Mind and Body ………………......................... 136

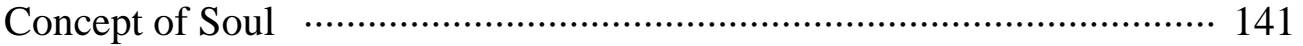

Death ……………………………………………………………… 145

Death and Eternal Life ……………………………………………... 146

A New Look on Death …………………………………………... 148

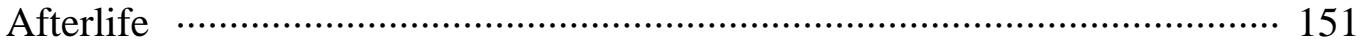

Pareschatology as a Product of Pluralism ……………………………..... 156

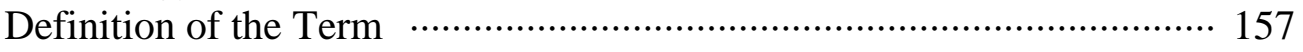

The Survival of the Disembodied Mind …………………………….... 159 
The Resurrection of the Person …………………………........................ 165

Reincarnation …………………………………………………. 172

Basic Conception of Reincarnation ……………………............... 174

Rebirth in Buddhism ……………………………….................... 176

Christianity and Reincarnation …………………………………..... 179

Memories and Reincarnaion …………………………………... 181

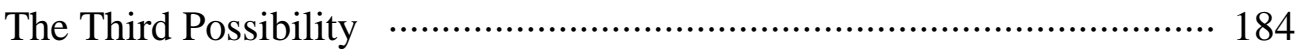

The Bardo World ...................................................................... 185

The "Next World" in Western Spiritualism ……………………..... 186

Critique of the Idea of the Immortal Ego ………………………….... 187

Hick's Pareschatology Model: Many Lives in Many Worlds ……… 190

A Possible Eschatology …………………………………………….... 195

Summary and Conclusions

V. CRITICAL EVALUATION OF HICK'S PLURALISM IN LIGHT OF

PARESCHATOLOGY ………………………………............................... 210

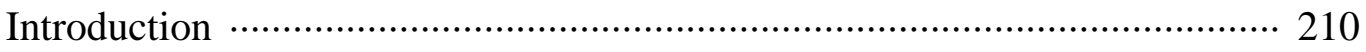

Pareschatology Criticized in Light of Correspondence Theory ……………. 212

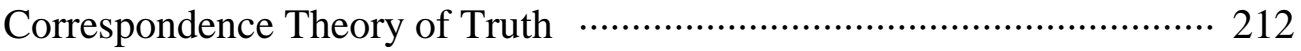

Pareschatology and Criticisms from Correspodence Theory …………….. 214

One: The Real, Pareschatology and Correspondence Theory ……….. 214

Two: Anthropology, Pareschatology and Correspondence Theory … 217

Three: Death, Pareschatology and Correspondence Theory ……….... 219

Four: Afterlife, Pareschatology and Correspondence Theory …….... 221

Pareschatology Criticized in Light of Coherence Theory ………………...... 223

Coherence Theory of Truth ……..................................................... 223

Pareschatology and Criticisms from Coherence Theory …….................. 224

One: Principles of Method, Pareschatology and Coherence Theory $\cdot 225$

Two: Anthropology, Pareschatology and Coherence Theory ………... 229

Three: Theology of Death, Pareschatology and Coherence Theory $\cdots 233$

Four: Afterlife, Pareschatology and Coherence Theory …………... 236

Five: Soul-Making, Pareschatology and Coherence Theory ………... 238

Six: Universal Salvation, Pareschatology and Coherence Theory …... 242

Conclusion: Criticism of Hick's Religious Pluralism as a Whole …………... 247

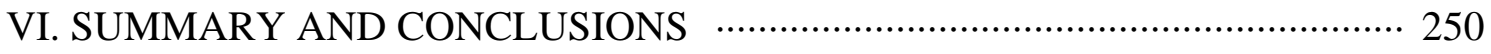

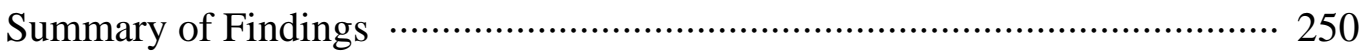

Hick's Life and Religious Pluralism ……………………………….. 250

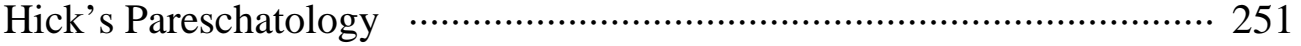

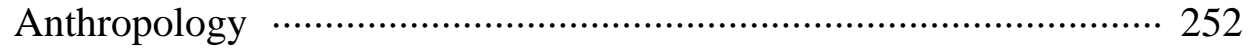

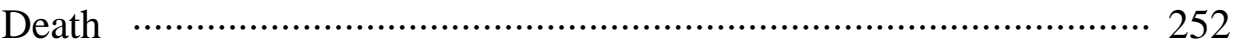

Afterlife ………………………………………………… 253

Pareschatology as a Product of Pluralism ……………………..... 253 
Criticisms of Hick's Pareschatology ………………............................. 254

Principles of Method: Two Criticisms ……………...................... 254

The Real: Two Criticisms ………………………………………... 255

Anthropology: Three Criticisms …………………………………... 257

Death: Three Criticisms ………………………………………… 257

Afterlife: Three Criticisms ………………………………………. 258

Soul-making: Three Criticisms ………………………………....... 260

Universal Salvation: Four Criticisms ……………………………... 261

Conclusions …………………………………………………………. 262

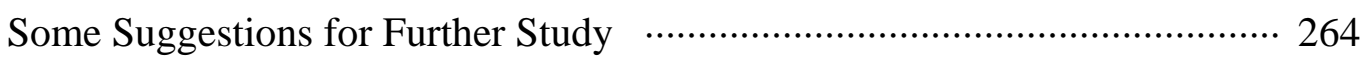

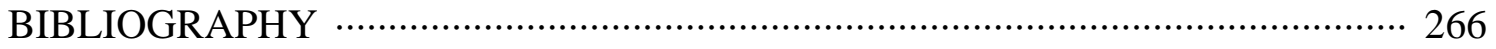




\section{CHAPTER I}

\section{INTRODUCTION}

\section{Background of the Problem}

Religious pluralism is one of the most influential philosophical approaches in the postmodern world. It is to be understood in the light of philosophical pluralism, which is “a philosophical perspective on the world that emphasizes diversity rather than homogeneity, multiplicity rather than unity, difference rather than sameness.” ${ }^{1}$ Religious pluralism, ${ }^{2}$ according to John Hick, is "the view that the transformation of human existence from self-centredness to Reality-centredness is taking place in different ways within the contexts of all the great religious traditions. There is not merely one way but a plurality of ways of salvation or liberation.”3 Along with many other theologians and philosophers, a contemporary British philosopher of religion and theologian, John Hick (1922-) $)^{4}$ has offered "one of the most sophisticated and influential pluralistic

${ }^{1}$ Calvin O. Schrag, “Pluralism,” The Cambridge Dictionary of Philosophy, ed. Robert Audi (New York: Cambridge University Press, 1999), 714. mentioned.

${ }^{2}$ From now on "pluralism” refers to religious pluralism unless otherwise

${ }^{3}$ John Hick, Problems of Religious Pluralism (New York: St. Martin’s, 1985), 34.

${ }^{4}$ See John Hick, John Hick: Philosopher of Religion and Theologian, http://www.johnhick.org.uk/, 2007 (accessed September 24, 2007). He currently holds the following titles and positions: "an Emeritus Professor of Claremont Graduate University, California; University of Birmingham, UK; Fellow of the Institute for Advanced Research in Arts \& Social Sciences, University of Birmingham, a Vice- 
philosophies of world religions." ${ }^{5}$ The research of this dissertation concerns Hick's pluralistic model of world religions, what he frequently calls "religious pluralism," or "the pluralistic hypothesis"- “The idea that each of the great world religions is response to the ultimately real, and that each is a context of human salvation.” ${ }^{6}$ More particularly, the focus will be on Hick's eschatological model within the entire system of religious pluralism.

According to the modern and postmodern mind-set, a person's religion is no longer the true religion but only one of many equally valid alternatives. While the diversity of world religions was an undeniable phenomenon in the past, as Gordon D. Kaufman notes, in the present the diversity of world religions has been more fully recognized, experienced, and sometimes even positively evaluated by adherents of all

President of British Society for the Philosophy of Religion and of the World Congress of Faiths" (ibid.).

${ }^{5}$ Paul Eddy, "Religious Pluralism and the Divine: Another Look at John Hick's Neo-Kantian Proposal," Religious Studies 30, no. 4 (Dec. 1994): 467. Many admit that John Hick is one of the most influential thinkers on religious pluralism. See Yong Huang, "Religious Pluralism and Interfaith Dialogue: Beyond Universalism and Particularism," International Journal for Philosophy of Religion 37, no. 3 (June 1995): 128; William L. Rowe, “Religious Pluralism,” Religious Studies 35, no. 2 (June 1999): 139.

${ }^{6}$ John Hick, A Christian Theology of Religions: The Rainbow of Faiths (Louisville, KY: Westminster John Knox, 1995), 41. See John Hick, "The New Map of the Universe of Faiths," in Contemporary Philosophy of Religion, ed. Steven M. Cahn and David Shatz (New York: Oxford University Press, 1982); idem, Problems of Religious Pluralism, 47; idem, An Interpretation of Religion: Human Responses to the Transcendent (New Haven: Yale University Press, 1989), 231, 233; idem, A Christian Theology of Religions: The Rainbow of Faiths, 11, 31, 34, 41, 42, 43. 
world religions. "'What is questionable is the 'pluralistic theology' that is proposed by many of the writers”8 in the postmodern world, according to Gavin D’Costa.

From the Christian point of view, for example, there have been several approaches toward understanding other religions. These approaches are summarized by Alan Race in three categories: exclusivism, inclusivism, and pluralism. ${ }^{9}$ This threefold typology was more fully developed by Gavin D’Costa, who defined the terms more precisely from the Christian perspective: (1) exclusivism ${ }^{10}$ — “only those who hear the Gospel proclaimed and explicitly confess Christ are saved”; (2) inclusivism—“Christ is the normative revelation of God, although salvation is possible outside of the explicit Christian church, but this salvation is always from Christ”; (3) pluralism ${ }^{11}$ — “all religions are equal and valid paths to the one divine reality and Christ is one revelation among

${ }^{7}$ Gordon D. Kaufman, God-Mystery-Diversity: Christian Theology in a Pluralistic World (Minneapolis: Fortress, 1996), xii.

${ }^{8}$ Gavin D’Costa, ed., Christian Uniqueness Reconsidered (Maryknoll, NY: Orbis Books, 2004), iii, iv.

${ }^{9}$ Alan Race, Christians and Religious Pluralism: Patterns in the Christian Theology of Religions, 2nd ed. (London: SCM, 1993). These same attitudes can be applied to any religious tradition toward others.

10 The basic attitude of exclusivism is expressed well at the Fourth Lateran Council (1215) when it repeated "the Cyprianic maxim: 'Extra ecclesiam nulla salus' (outside the church there is no salvation) (Carl E. Braaten, "The Problem of the Absoluteness of Christianity,” Interpretation 40, no. 4 [Oct. 1986]: 342). This attitude is also seen in Hegel's philosophy of religion which refers to Christianity as the "absolute religion” (ibid.). It is clearly repeated in Parson Thwackum's word as he said, "When I mention religion, I mean the Christian religion; and not only the Christian religion, but the Protestant religion; and not only the Prostestant religion, but the Church of England" (John Hick, The Center of Christianity [San Francisco: Harper \& Row, 1978], 70, 71).

${ }^{11}$ Hick prefers the term "pluralism," to "relativism” to describe the view that all religions are only different responses to the same divine Real and thus salvific as totalities. John Hick, "Pluralism and the Reality of the Transcendent," in Theologians in Transition, ed. James M. Wall (New York: Crossroad, 1981), 61-62. 
many equally important revelations.”12 Hick has responded to this threefold typology with regard to "both truth-claims and salvation-claims."13 He argues for pluralism, ${ }^{14}$ listing the reasons that exlusivism is problematic, ${ }^{15}$ and that inclusivism is not sufficient and inevitably leans toward pluralism. ${ }^{16}$

Hick's influential and sophisticated pluralistic model of religions is well described in A Christian Theology of Religions: The Rainbow of Faiths. He says: "Christianity is only one among several great world religions. Judaism, Islam, Hinduism, and Buddhism now appear to many as different but, judging by their fruits in human life, equally authentic responses to . . . the Real."17 The basic thesis of Hick’s pluralism is centered

${ }^{12}$ Gavin D’Costa, “Christian Theology and Other Faiths,” in Companion Encyclopedia of Theology, ed. Peter Byrne and Leslie Houlden (New York: Routledge, 1995), 292.

${ }^{13}$ Hick, A Christian Theology of Religions: The Rainbow of Faiths, 18.

${ }^{14}$ As Edward G. Schied notes, "For Hick the Christian forms of exclusivism and inclusivism are inappropriate and insufficient to correctly interpret the plurality of religions because they leave finite, historical Christianity at the center of the universe of religious expressions as normative judge over all” (Edward G. Scheid, "Scripture and Theology of the Religions: On the Theological Interpretation of Sacred Scripture in Christian Attitudes toward World Religions” [Pittsburgh, PA: Duquesne University, 1992], 152).

${ }^{15}$ Hick, A Christian Theology of Religions: The Rainbow of Faiths, 19. He says that "exlusivism asserts that salvation is confined to Christians, or . . . outside the church there is no salvation” (ibid.).

${ }^{16}$ Ibid., 20, 21. According to Hick, inclusivism acknowledges that "the salvific process is taking place throughout the world, within each of the great world faiths ... but insists that wherever it occurs it is the work of Christ” (ibid.). Here he uses Karl Rahner's famous concept of "anonymous Christians.” For more information, see Karl Rahner, "Christianity and Other Religions," in Christianity and Other Religions, ed. John Hick and Brian Hebblethwaite (London: William Collins Sons, 1980), 75-79.

${ }^{17}$ Hick, A Christian Theology of Religions: The Rainbow of Faiths, iv. 
upon the concept of the Real, ${ }^{18}$ which has a complex definition in Hick's pluralistic hypothesis. The Real, which he calls "the ultimate Reality, not one among others," is "an unknown and unknowable Ding an sich." ${ }^{\prime 19}$ The Real in itself as the ultimate noumenon is only known through multiple phenomenal appearances. ${ }^{20}$ His explanation of the Real relies on a Kantian analysis of differences between the noumenal and phenomenal. ${ }^{21}$ The former, the Real as it is in itself, is never the direct object of religious experience, while the latter is perceived and experienced differently in every religion. ${ }^{22}$ Hick, however, proposes some ideas about the Real and its salvific act on the lives of every religion's adherents. $^{23}$

Two important elements—-theocentric and eschatological—must not be overlooked in Hick's pluralistic hypothesis of world religions, because the first is a theoretical basis upon which other elements are built and the latter an inevitable result of

${ }^{18}$ John Hick, God Has Many Names (Philadelphia: Westminster, 1982), 36. See also idem, An Interpretation of Religion: Human Responses to the Transcendent, 10, 11.

${ }^{19}$ Hick, An Interpretation of Religion: Human Responses to the Transcendent, 249. Ding an sich is a Kantian term that signifies the "Real in itself" in Hick's argument.

${ }^{20}$ See ibid., 247.

${ }^{21}$ Samuel Enoch Stumpf, Socrates to Sartre: A History of Philosophy (New York: McGraw-Hill, 1966), 314, 315. 241, 242.

${ }^{22}$ Hick, An Interpretation of Religion: Human Responses to the Transcendent,

${ }^{23}$ Though admitting the impossibility of knowing the Real in itself, he claims that "the great world faiths embody different perceptions and conceptions of, and correspondingly different responses to the Real from within the major variant ways of being human; and that within each of them the transformation of human existence from self-centeredness to Reality-centeredness is taking place” (ibid., 240). 
his theocentrism. First, Hick's thoughts on the theocentric model ${ }^{24}$ of world religions play a key role in his pluralism. In his book God and the Universe of Faiths, he offers his proposal for a "Copernican revolution" as applied to Christianity and the world religions, according to which "God takes the place of Christ (or church) that becomes the center of religions.”25 Great world religions are, according to this model, seen as their own responses to the Real, which may be different depending on time and culture. ${ }^{26}$

The second important aspect in Hick's proposal of religious pluralism is eschatology or pareschatology, ${ }^{27}$ which is a result of his theocentric model of world religions. Eschatology must be dealt with in light of his soteriology, which Hick considers one of the common elements of major world religions. ${ }^{28}$ To him, all major world religions are their own responses to the Real and salvific, and provide eschatologies of their own in different forms as a result of their own theologies. Hick examines the survival of man, the resurrection of the person, and the reincarnation after death in his Death and Eternal Life. He describes, explains, and compares the various

\footnotetext{
24 The concept of the Real is one of the major examples of the theocentric model of world religions.

${ }^{25}$ John Hick, God and the Universe of Faiths: Essays in the Philosophy of Religion (New York: St. Martin’s, 1973), 131.

${ }^{26}$ Ibid., 120-147. As Paul Knitter points out, some questions are raised: "Why are there so many different religions? If God is one, should there not be one religion?” (Paul Knitter, Theologies of Religions [Maryknoll, NY: Orbis Books, 2004], 1).

${ }^{27}$ John Hick, Death and Eternal Life (London: Collins, 1976), 22. Using a combination of two Greek words, para and eschata, Hick defines pareschatology as the doctrine of "next-to-last things" (ibid.). Hick uses this term to signify "the human future between the present life and man's ultimate state" (ibid.). Thus, his pareschatology is the doctrine of human experience from death to the ultimate state.

${ }^{28}$ Hick, An Interpretation of Religion: Human Responses to the Transcendent, 32, 33, 36. For more details about Hick's eschatology, see Hick, Death and Eternal Life.
} 
eschatologies held by each major religion and insists that all major world faiths point toward a common belief in the final and eternal state. However, he is not satisfied with this task of simply discussing and comparing various eschatologies from East (e.g., reincarnation of Hinduism or Buddhism) and West (e.g., heaven or hell of Christianity) and integrating them. Rather, he tries to introduce something new, which he calls "a third possibility, other than eternal-heaven-or-hell or repeated earthly reincarnations.” ${ }^{29} \mathrm{He}$ suggests a new idea that there are "a series of lives ... lived in other worlds in spaces other than that in which we now are.”30 According to Hick, there will be several afterlives in many different worlds before all will ultimately be saved. ${ }^{31}$

Some questions may be raised: Does Hick’s eschatological model provide a real solution, as perceived by critics, for all apparent dilemmas consequent upon mutual exclusivity in eschatological claims? Does an inconsistency exist in Hick’s theology when he endorses all eschatologies while not accepting any one of them? These questions lead to the problem statement.

\section{Statement of the Problem}

Based upon preliminary research, Hick’s religious pluralism seems to reveal a critical problem with external correspondency, as follows. His pareschatology, which is an attempt to accept all eschatologies ${ }^{32}$ of major world religions as valid, may as a

${ }^{29}$ Hick, Death and Eternal Life, 456.

30 Ibid.

${ }^{31}$ Ibid., 47, 209, 210, 419. Hick claims that the number of afterlives will be different for people depending on their closeness to the Real.

32 Though he claims to consider all possible options for eschatologies or pareschatologies from world religions, Hick finally ends up with only two models from East and West. 
consequence tend to invalidate them all in the end. Moreover, other factors may indicate the presence of inconsistencies in Hick's pareschatological model, which may reflect upon the adequacy of his overall model of religious pluralism.

\section{Purpose of the Research}

The purpose of this dissertation is to address and critically evaluate the external correspondency and internal consistency of Hick's eschatological model, which may provide the basis for a critical evaluation of his religious pluralism as a whole.

\section{Justification for the Research}

Though it is true that Hick's pluralism attracts great attention from scholars of both liberal and conservative circles, ${ }^{33}$ his eschatological model has been largely overlooked. Hick's eschatological model cannot, however, simply be ignored, because it is an inevitable result of his pluralistic hypothesis of world religions.

Hick's eschatological model may function as a yardstick in evaluating the validity of his religious pluralism, because his eschatological model has theological ramifications relating to religious beliefs about the existence of God, life after death, and the experience of salvation. Therefore, studying Hick's model of eschatology is one of the effective ways for evaluating the validity of his pluralistic model of world religions.

\section{Scope and Delimitations}

Hick’s pluralistic model has been examined, evaluated, and criticized by numerous theologians, scholars, and philosophers of many different perspectives around

${ }^{33}$ Many scholars from conservative circles have challenged his pluralism, while many others from liberal circles have been in agreement with his view, as will be discussed. 
the world. For example, several dissertations have been written on Hick’s religious pluralism in areas such as epistemology, authority, the concept of God, and

Christology, ${ }^{34}$ but not on his eschatological model. Therefore, this study will focus on the eschatological model of Hick’s religious pluralism, namely his pareschatology.

Most of John Hick’s published works will be used for the discussion, while a special emphasis will be given to works such as An Interpretation of Religions: Human Responses to the Transcendent; and Death and Eternal Life.

\section{Methodology}

Hick has written and edited many books and produced numerous articles, advocating and defending religious pluralism over thirty years. He has tried to avoid apparent dilemmas and contradictions of each religion in its encounter with others in truth claims by developing his own first theocentric and later realocentric model of world religions. His eschatological model is one of the crucial components that should not be overlooked, because it is a natural product of his pluralistic hypothesis. His goal in all of his theories of pluralism and its eschatological model is to create internal coherence. The fundamental difficulty in evaluating Hick's proposed eschatological model, however, is that theologically it has no parallel theological system or model to compare with.

Thus, Hick’s eschatological model will be evaluated within his own system of

\footnotetext{
${ }^{34}$ For more on these subjects see the following dissertations: Gavin D'Costa, John Hick's Theology of Religions: A Critical Evaluation (Lanham, MD: University Press of America, 1987); Paul R. Eddy, "John Hick’s Pluralist Philosophy of World Religions: An Exposition and Response” (Ph.D. diss., Marquette University, 1999); Terry R. Mathis, "The Place of Eschatological Verification in John Hick's System of Thought" (Ph.D. diss., Claremont Graduate University, 1984); David S. Nah, "A Critical Evaluation of John Hick’s Theology of Religious Pluralism” (Ph.D. diss., Claremont Graduate University, 2005).
} 
thought, whether he is coherent to himself. Two basic theories of $\operatorname{truth}^{35}$ will be used to evaluate Hick’s eschatological model, because Hick himself employs them in his argument for his theory of world religions. An obvious example is that when Hick encounters the different and sometimes mutually contradictory concepts of God and experiences of salvation in religions (e.g., theism with atheism and heavenly kingdom with nirvana), he tries to resolve the dilemma of being mutually contradictory by employing the concept of the Kantian distinction between the noumenal and phenomenal. ${ }^{36}$ In other words, he does not want to be contradictory to himself by accepting mutually exclusive claims of two different religions.

The following will be the design of the rest of this dissertation. Chapter 2 will be biographical, including Hick’s personal and theological journey. This chapter will serve as a preliminary work for the study, because it will show his presuppositions and what kind of personal burdens he has.

Chapter 3 will be the investigation of Hick's pluralistic hypothesis, which is a necessary prerequisite to a discussion of Hick’s eschatological model. His pluralistic

35 Two major theories of truth include the correspondence theory of truth and the coherence theory of truth. The former is perhaps the most widely held and employed account of truth by numerous thinkers throughout history. The theory holds that a belief is true when there exists a fact corresponding to it. See Paul Horwich, "Truth," The Cambridge Dictionary of Philosophy, ed. Robert Audi (Cambridge; New York: Cambridge University Press, 1999), 929-931. The latter claims that the more our beliefs hang together in a system, the truer they are. Thus, it would claim "the beliefs of a given individual are true to the extent that the set of all their beliefs is coherent" (Richard L. Kirkham, "Coherence Theory of Truth,” Routledge Encyclopedia of Philosophy, ed. Edward Craig [London; New York: Routledge, 1998], 9:470). Every claim that Hick makes, for example, must be consistent with other claims that he makes somewhere else in order to be truthful. Unless one of Hick's claims is consistent with his other claims, the validity of his entire system is in question.

${ }^{36}$ See Hick, An Interpretation of Religion: Human Responses to the Transcendent, 241, 242. 
hypothesis, particularly his theocentric model of world religion, is the basis of other parts of his theoretical system, and must be dealt with as a theoretical framework in order to understand his eschatology.

Chapter 4 will address in detail Hick's proposal for a new model of eschatology, which is a natural consequence of his pluralistic hypothesis of world religions. This chapter will focus on the eschatological claims of Hick's religious pluralism, along with related issues essential for a proper understanding of the nature and destiny of human beings. These include the origin of man, the soul, afterlife, death, reincarnation, and resurrection as discussed in Death and Eternal Life. This discussion will set the stage for an evaluation of Hick's pareschatology, which is one of the crucial components of his entire pluralistic hypothesis.

In chapter 5, using his own logical principles, Hick’s pluralism will be evaluated in light of his own eschatological model, pareschatology. This evaluation will be done by assuming the correspondence and coherence theories of truth. Accordingly, this chapter will address the issue of internal consistency and inconsistency of his eschatological model, which will give a critical evaluation of Hick’s religious pluralism.

Chapter 6 will present the summary and conclusions of the dissertation along with some suggestions for further study. 


\section{CHAPTER II}

\section{JOHN HICK, THEOLOGIAN AND PHILOSOPHER}

\section{Introduction}

Looking at the life of John Hick is key to understanding his belief in religious pluralism. A person's theology does not arise from a vacuum but from one's lifelong theological journey and experience as a theologian. John Hick’s own theological understanding has gone through many transformations from an evangelical Christianity to a liberal one, and finally to religious pluralism—- “from exclusivism, to inclusivism, to pluralism"1 — throughout several periods of his life. Thus, it is crucial to look at Hick's life journey in order to gain a better understanding of his religious pluralism. In this chapter I will take a closer look at Hick's life from his earliest childhood to the present to see how he was brought up as a person and a theologian as well as a philosopher.

Being a shipping family in Scarborough, England, and having never been either noble or notable, John Hick’s family tree goes back to "before the registration of births, deaths and marriages in England in 1837.”2 Hick’s ancestors were leading shipping men in the late nineteenth century in Scarborough. Hick's mention of a group picture of his grandfather's generation in his dining room, taken probably in the 1880 s or ' 90 s "when

\footnotetext{
${ }^{1}$ Veli-Matti Kärkkäinen, An Introduction to the Theology of Religions (Downers Grove, IL: InterVarsity, 2003), 283.

${ }^{2}$ John Hick, John Hick: An Autobiography (Oxford: Oneworld, 2002), 1.
} 
they were the leading shipping family in Scarborough,”3 shows Hick’s view of his ancestors. He must have been proud of his ancestors who appeared in the picture, "most of whom have been at sea for many years, have faced dangers and hardships, and who have been successful in life." ${ }^{4}$ However, Hick’s own grandfather, Albert Edwin, in his generation was the only one who did not go into the shipping business among his siblings, and instead became a solicitor, "setting up on his own in Scarborough at the age of twenty-three or four."5 Hick’s grandfather was a public figure and was actively involved in many public services in the town. This great involvement in public service must have been possible through the wealth that his wife inherited from her father. Hick's father, Mark, was also a solicitor, but his real interest was tennis. ${ }^{6}$ As a matter of fact, Mark was one of the British seeded players at Wimbledon (1912-1925), and won several regional championships big and small. ${ }^{7}$ In his short descriptions of his ancestors, Hick shows that his ancestors were successful people in their own areas.

\section{Biographical Background of Hick}

John Harwood Hick was born and raised in a conservative Christian family in Scarborough, England. His autobiography, John Hick: An Autobiography, describes his life journey well and will be the main source of this biographical sketch. The way in

\footnotetext{
${ }^{3}$ Ibid., 9.

${ }^{4}$ Ibid.

${ }^{5}$ Ibid., 8.

${ }^{6}$ Ibid., 12.

${ }^{7}$ Ibid., 20.
} 
which he describes his life is very precise and detailed, perhaps because he had a habit of keeping records of his life events that stemmed from teenage years.

\section{Early Life}

\section{Family Background and Childhood}

"John Harwood Hick was born in Scarborough, England in 1922, the son of a solicitor,"8 Mark Hick, who himself was a second-generation solicitor. Due to a considerable amount of inheritance from his grandmother Maria, and his father's successful investment in the stock market which would have increased his inheritance, his early childhood was spent in what "seemed to be a well enough off middle class family, employing a cook and a maid, an occasional handyman, at one time a nanny and later a tutor." ${ }^{9}$ However, Hick’s family went through a major financial disaster when his father's big investment in the east did not turn out to be successful in $1939 .^{10}$

John Hick’s relationship with his father was not always very good, maybe because of their different views on issues such as politics and war. Hick specifically described and listed the differences between him and his father and said: “On his side, he was politically conservative whilst I was a socialist, he was disappointed that I switched from the Law to the Presbyterian ministry, and during the war he was a conventional patriot whilst I was a conscientious objector." ${ }^{11}$ Continuous tension existed between them, particularly when World War II approached, because of their drastically different views

${ }^{8}$ Ibid., 323.

${ }^{9}$ Ibid., 12.

${ }^{10}$ Ibid. Hick was not sure of what it was, but he thought that his father invested in a rubber business that was promising in the east, and it failed.

${ }^{11}$ Ibid., 19. 
on war. For example, Hick’s diary, kept in July 1939, shows the tension that existed between them: “[I] had a bad quarrel with Dad at dinner today. I do not know how it began, and I myself was more of a spectator than a combatant, but Dad was very annoyed over my lack of patriotic bias in viewing history! M. [Mark] appeared in tears afterwards asking me not to let it happen again.”12 The gap between father and son became even greater when Hick became an actual conscientious objector after the war broke out. Mark’s genuine patriotism must have been damaged by his son whose idea of war was totally different from his. Hick was against the idea of violence and became a conscientious objector due to the conviction that "the teachings of Jesus were utterly incompatible with the mass violence of war.”"13 Mark must have thought that he lost his reputation in the town with his “conchie” son. This was only one of many reasons why they were in constant conflict. Though Mark appeared to be irrationally attached to his own ideas, he was not at all unintelligent. He was a man of great talent in many areas such as chess and bridge, playing both for Yorkshire.

\section{Education}

Hick had a bad experience in grade school in Lisvane, which was just around the corner from his home. This was a private school that he attended, and Hick remarked that his experience there was awful. Afterwards he was homeschooled for a while by a tutor with his brother Pentland, who was two years older; and then at the age of fifteen Hick went to Bootham school in York for two years, where he finally enjoyed his time. He read many books, particularly the Penguin Classics that dealt with philosophical writings,

12 Ibid., 20.

13 John Hick, “A Pluralist View,” in More Than One Way? ed. Dennis L. Okholm and Timothy R. Phillips (Grand Rapids, MI: Zondervan, 1995), 30. 
in $1935,{ }^{14}$ and also began to enjoy writing and even published some of his works in the school magazine.

As the son of a solicitor, regardless of his philosophical bent, Hick, after he left Bootham, began to work as an articled clerk at Hick \& Hands (his father's law office). While he was there, he took some special tutoring at home and passed the Law Prelim and attended law lectures at the University College (now the University of Hull) to be a solicitor like his father and grandfather.

From age seventeen, Hick began to read philosophers such as Nietzsche, Leibniz, Mill, Schopenhauer, Whitehead, Freud, and Russell. He thought that he had a natural bent for philosophy. ${ }^{15}$ In the diary that he kept when he was seventeen, he said: "I wonder whether thinking is necessary. I think it is for some people and not for others. It is for me!”16 He even wrote, "Real philosophers in my opinion are born, not made, and I think that I was born one.”17 Hick began to show his strong interest in philosophy from his early college years. "It was a revelation to read about Plato, Descartes, Locke, Berkeley and Hume, and above all Kant,"18 said Hick.

About this time, Hick had a chance to meet with Edward W. Hirst, his mother Aileen’s uncle, who had been “a Lecturer in Christian Ethics at Manchester University and in the United Methodist and Harley Colleges.”19 After reading Hick’s essay called

\footnotetext{
${ }^{14}$ Hick, John Hick: An Autobiography, 18.

${ }^{15}$ He even claimed that he was a born philosopher rather than a made one.

${ }^{16}$ Hick, John Hick: An Autobiography, 15.

17 Ibid., 70.

18 Ibid., 15.

${ }^{19}$ Ibid., 16.
} 
'The Dreamer's Vision,' Hirst suggested that he should go to a university and study philosophy and could teach at a university in the future. Hick, however, thought that the Law was a safer prospect and began to take law classes at the University of Hull to be a solicitor while also taking philosophy classes. ${ }^{20}$ He must have thought that he could maintain his life through his profession as a solicitor, and at the same time enjoy philosophy as his hobby.

\section{Religious Experiences}

As an average Englishman of the time, Hick was brought up in a Christian family. He was baptized as a baby in the Church of England and attended services as a child and teenager. To him Christianity seemed to be "utterly lifeless and uninteresting," its services “a matter of infinite boredom.. ${ }^{21}$ Hick’s early exposure to Christianity was through his Granny (Aileen's mother), who was very much involved in all sorts of religious activities. She took him to religious activities during his early teenage years. One specific event that left a big impression on his early years was when a well-known evangelist, George Jefferys, laid his hands on his head in a farewell prayer meeting. Hick had this unique experience when he was twelve. He described his experience in the event as follows: "I was kneeling at a chair when Jeffreys, coming round the circle, laid his hands on my head. I immediately felt a strong physical effect, like an electric shock except that it was not a sharp jolt but a pervasive sensation spreading down through my

\footnotetext{
${ }^{20}$ Ibid.

${ }^{21}$ Hick, “A Pluralist View,” 29.
} 
body. I was in floods of tears_-not of sadness or fright but, I suppose, a tremendous emotional impact."22

Apart from his Granny's influence, there was his mother, Aileen, who was also a very religious person whose spiritual interest took a different form than her mother's and must have made a considerable impact on his life. She believed in Spiritualism, which flourished during World War I. She was also thought to be psychic and frequently saw apparitions. Hick had some chances to observe spiritualists performing spiritualism, but he found them unconvincing. He had "a strong rationalist streak" which came out quite often in his diaries. ${ }^{23}$ He however had no doubt about the reality of extrasensory perception, or telepathy, which seemed to be a result of his mother’s influence. He had a chance to encounter publications by the Society for Psychical Research and was impressed by them. He was “a member of the Society for many years, reading its regular publications, ${ }^{24}$ having joined at the suggestion of his Oxford doctoral supervisor, H. H. Price, who was an author of philosophical discussions of psychical research, or parapsychology.

Hick also read some theosophical literature through one of Aileen's friends who was a Theosophist. ${ }^{25}$ At the age of eighteen, when he was an articled clerk, he was “attracted by theosophy as the first coherent religious philosophy that I had met-much

${ }^{22}$ Hick, John Hick: An Autobiography, 27.

23 Ibid., 29.

24 Ibid.

25 Theosophy is a nineteenth-century Western philosophy created out of elements of Hinduism and Buddhism by Madam Blavatsky, founder of the Theosophical Society in 1875 (ibid.). 
more so than the Christianity I knew." ${ }^{26}$ Not long after Hick developed a strong interest in it, he consciously dismissed it. However, he professed that he gained a strong interest in the Eastern religions, which was not active during his evangelical Christian experience, but then came back at a later period in his life. At this time, though Hick did not believe in the God of traditional Christianity, he had a strong conviction during this time that there was some sort of divine reality. This belief in a divine reality played a major role in his pluralistic hypothesis of world religions, because this reality was the center upon which all other elements of religions are focused. This idea of divine being is the basic concept for his "Copernican revolution.”

At the age of eighteen, when he was studying law at University College, Hull, Hick had a strong conversion experience into traditional and evangelical Christianity. "The converting power" that he experienced was, he recalls, "the New Testament picture of Jesus Christ." ${ }^{27}$ He described his unforgettable conversion story as follows:

For several days I was in a state of intense mental and emotional turmoil, during which I became increasingly aware of a higher truth and greater reality pressing in upon me and claiming my recognition and response. At first this was highly unwelcome, a disturbing and challenging demand for nothing less than a revolution in personal identity. But then the disturbing claim became a liberating invitation. The reality that was pressing in upon me was not only awesomely demanding but also irresistibly attractive, and I entered with great joy and excitement into the world of Christian faith. Some of my fellow students were members of the InterVarsity Fellowship, the evangelical campus organization; and throwing in my lot with them, I accepted as a whole and without question the entire evangelical package of theology - the verbal inspiration of the Bible; Creation and Fall; Jesus as God the Son incarnate, born of a virgin, conscious of his divine nature, and performing miracles of divine power; redemption by his

${ }^{26}$ Ibid., 31.

${ }^{27}$ John Hick, Disputed Questions in Theology and the Philosophy of Religion (New Haven: Yale University Press, 1993), 139. 
blood from sin and guilt; Jesus’ bodily resurrection, ascension, and future return in glory; heaven and hell. ${ }^{28}$

Hick likes to refer to this experience as “a fundamentalist conversion,” 29 which accepts "the entire evangelical package of theology" that he later considered as intellectually unacceptable.

This conversion experience into traditional Christianity completely changed his life. Planning to serve as a minister of the Presbyterian Church of England that his InterVarsity Fellowship friends belonged to, he transferred to Edinburgh University, switching from the Law to the Christian ministry. He remained an evangelical fundamentalist in his college years as well as during his time in the Friends Ambulance Unit. $^{30}$ He claimed that he was "highly orthodox" during his time as a student at Westminster College, and even after college at Belford church as a minister, at Cornell, and Princeton Theological Seminary as a professor.

During this period after the war, Hick’s theology began to be open to more liberal thought. For instance, he began raising some questions of intellectual doubts: "Could one understand the sun standing still for about a day as recounted in Joshua 10:13?”; “Can biological evolution responsibly be rejected just because it is contrary to the book of Genesis?”; “And could it really be an expression of infinite love to send the majority of the human race to eternal torment in hell?"31 Confronted with these questions, Hick seemed to feel that "they were dangerous and ought not to be raised, and that they

${ }^{28}$ Hick, “A Pluralist View,” 29, 30.

${ }^{29}$ Ibid., 33.

${ }^{30}$ Hick, John Hick: An Autobiography, 34, 35.

${ }^{31}$ Hick, “A Pluralist View,” 31. 
constituted a temptation to backsliding." ${ }^{32}$ Though he did not disregard all of his former faith, Hick was starting to stray from his fundamentalist view of Christianity.

\section{Publications}

The pilgrimage of Hick from a conservative Christian theologian to a pluralist philosopher is well revealed in his writings and publications. They are one of the barometers by which to see his theological development throughout his lifetime. It is almost impossible to include all his writings and publications over sixty years of his writing career ever since he began to write his diary at the age of seventeen. He has been quite actively involved in writing and publishing many books and numerous articles on the scholarly world in the past several decades. Today in his late eighties, Hick still writes and publishes books. For example, even after publishing his autobiography, John Hick: An Autobiography (2002), Hick did not stop writing. Two new books recently came out: The New Frontier of Religion and Science: Religious Experience, Neuroscience and the Transcendent (2006), and Who or What Is God? And Other Investigations (2008).

In this section, I will examine a few of Hick's major works that were monumental to his development of ideas in the theology of world religions. In order to see his change of theological presuppositions, some of his major books will be listed and described in chronological order. His first book, a revision of his doctoral thesis at Oxford, Faith and Knowledge (1957), ${ }^{33}$ came out while he was teaching as an assistant professor of

32 Ibid.

33 John Hick, Faith and Knowledge, 2nd ed. (Ithaca, NY: Cornell University Press 1966). This was a revision of his D.Phil. degree thesis in 1953 at Oriel College, Oxford, entitled "Faith and Belief." 
philosophy at Cornell University. During this period he was still a conservative theologian who held onto the Chalcedonian orthodoxy, which is particularly concerned with the complete divinity of Jesus Christ.

While he was at Princeton Theological Seminary, Hick was asked to be featured in a special project commissioned by Prentice-Hall to write "a new series of short books on all aspects of philosophy, the Foundations of Philosophy series. ${ }^{34}$ Hick was asked to write on the area of philosophy of religion. This is how his most widely sold and read book until then, Philosophy of Religion (1963), came out. There we can find some open discussions about common elements of religions which would lead to the philosophical turn to pluralism later on, yet no hint of religious pluralism was evident.

Hick published his third book, Evil and the God of Love (1966), which has become one of the classic books in the area of theodicy. In this book he tries to prove that the classical understanding of the problem of evil that Augustine and his followers advocated is not valid anymore. Instead, he tries to show that the validity of an Irenaean understanding of the problem of evil is more appropriate than the Augustinian. Hick claims that Irenaeus distinguished two stages of the creation of people. In the first stage, human beings are created in God's image, that is, into existence as intellectual beings who are still immature creatures. In the second stage, they are created in God's "likeness," into existence transformed from human animals to God's children. This book builds a theoretical basis for the future development of religious pluralism.

In 1973, Hick published a monumental book entitled God and the Universe of Faiths, which is a fresh and shocking book on religious pluralism, composed of a series of essays that he had written previously. Here Hick suggests a new idea called the

${ }^{34}$ Hick, John Hick: An Autobiography, 122. 
“Copernican revolution”35 in regard to our understanding of world religions. Hick’s selfdescribed Copernican revolution in theology involves "a radical transformation in our conception of the universe of faiths and the place of our own religion within it." ${ }^{36}$ In other words, it involves a shift from a Christian-centeredness or church-centeredness to God-centeredness in the view of the universe of faiths. Thus, the great world religions are essentially the same, but are different human responses or perceptions to the one divine Reality due to the different historical and cultural circumstances.

Having launched his pluralistic theology of world religions and particularly of God in God and the Universe of Faiths (1973), Hick must have felt the need to explore an eschatology that fits his theory of world religions. As a result he published his new book, Death and Eternal Life, in 1976, which tries to present a global doctrine of death and afterlife. It is in this book that he introduced and explored his own eschatological model, namely pareschatology. This work was one of the concluding parts of his theoretical framework of religious pluralism, which inevitably has to show the end result for his pluralistic hypothesis. What Hick tried to do was to present an eschatology which embraced the models both from East (Buddhism and Hinduism) and West (Christianity). In other words, he suggested a new idea that there will be a series of lives in other worlds before we all will be saved ultimately.

In 1987, Hick edited with Paul Knitter Myth of Christian Uniqueness, which is composed of essays presented by the twelve contributors at the Claremont Graduate School in the previous year. Hick found other theologians and philosophers who were in

${ }^{35}$ For more about the "Copernican revolution" see Hick, God and the Universe of Faiths, 120-133.

${ }^{36}$ Ibid., 131. 
general agreement with his pluralistic theology of world religions. In the Preface, Knitter claims that the pluralist approach is "a move from the insistence on the superiority or finality of Christ and Christianity toward the recognition of the independent validity of other ways." 37 The contributors describe this kind of approach as "the crossing of a theological Rubicon” through three bridges: The Historical Cultural Bridge; The Theological Mystical Bridge; and The Ethico-Practical Bridge.

It was also during this period when Hick was at the Claremont Graduate University that he published his well-known book An Interpretation of Religion (1989), which is an expanded version of his 1986-7 Gifford Lectures, delivered at the University of Edinburgh. ${ }^{38}$ This volume is undoubtedly one of the most comprehensive and most influential books advocating religious pluralism. Hick's pluralistic hypothesis that the great world religions are different yet valid responses to the one Real is most extensively presented in this book. Hick even claims that "An Interpretation of Religion has been widely discussed, and indeed almost every treatment of the problem of religious diversity since has had something to say about it. It has helped to stir up a number-at the moment nearly thirty—books about my work, mostly by conservative Christian theologians and philosophers, a few of them making useful critical points.”39 This was no doubt his magnum opus, which received the 1991 Grawemeyer Award for the most significant new thinking in religion. However, Hick never stopped writing and publishing books and

${ }^{37}$ John Hick, ed., The Myth of God Incarnate (London: SCM, 1977), viii.

${ }^{38}$ Hick, An Interpretation of Religion: Human Responses to the Transcendent, xiii.

${ }^{39}$ Hick, John Hick: An Autobiography, 261. 
articles until very recently. I end my descriptions of his publication here for now, which will be further expanded later.

\section{Teaching Career}

Hick's pilgrimage as a theologian and philosopher is also reflected in his teaching career. In this section, I look at his teaching career, going from a minister of a local congregation to a university professor in the States and Great Britain over three decades. His life journey in his career clearly shows his change of theological and philosophical position.

Hick started his career as a minister of the Belford Presbyterian church, which is located "in Northumberland about fifteen miles south of Berwick-on-Tweed on the Scottish border." ${ }^{40}$ Hick started his ministry early in August 1953 and at the end of the month he married Hazel in the church. The Belford church had 296 members, which was "then the largest rural congregation in the denomination." 41

Hick's main job was to preach two sermons on Sunday and to go out visiting in the cottages and farms during the weekdays. He spent his mornings preparing two sermons, and when he was done with his sermons, he took the rest of his mornings revising his Oxford thesis into a book. His sermons were "biblically based and directed to a rural congregation few of whom had much education.”42 There was no vestige of religious pluralism during this time in his career as the minister of Belford Presbyterian church.
40 Ibid., 88.
${ }^{41}$ Ibid., 92.
42 Ibid. 
On Christmas day of 1954, Hick received a letter of invitation from Cornell University to teach philosophy of religion as an assistant professor. Wanting to accept the job offer and at the same time not to leave Belford so precipitately, he asked to postpone it until January 1956. He says that he really enjoyed Belford and felt in many ways sorry to leave there. Yet he did not want to miss the opportunity to go into the academic world.

\section{Cornell University (1956-1959)}

Hick’s teaching career as a university professor started at Cornell University in New York in January $1956 .{ }^{43}$ Cornell University was one of the prestigious Ivy League schools and was in general an academically liberal institution. During that time "Cornell had one of the strongest philosophy departments in the country, with a distinctive character as the leading US centre for the study of Wittgenstein, who had visited there not long before his death in 1951." 44 Though he learned a lot about Wittgenstein, he "was never drawn into the Wittgensteinian thought world, and retained a kind of independence from the dominant school of thought and the wider range of interests.”45

Hick’s first philosophy of religion lecture was an overwhelming one because of its size. There were over three hundred students waiting for his lecture, which he realized later was the legacy of Burtt whom he was replacing. Hick then considered Burtt as half a Buddhist, whom he thought to be too liberal, while seeing himself then as "a conservative

\footnotetext{
${ }^{43}$ For more about his stay at Cornell see ibid., 102-119.

${ }^{44}$ Ibid., 104.

${ }^{45}$ Ibid., 106.
} 
Christian." ${ }^{46}$ He says in his autobiography that his mind was closed to Burtt's wider vision during that time. ${ }^{47}$

His three-and-a-half-year stay at Cornell was a good opportunity to have many different experiences as a scholar and theologian. He not only had a chance to have an indepth study about philosophers such as Wittgenstein and Moore, but also learned how to teach while he was there. He was able to meet some prominent theologians and philosophers who came to visit Cornell, which later had a big impact on him. Among them were Paul Tillich, Reinhold Niebuhr, and Robert Calhoun. During the later period at Cornell, Hick was invited to McGill University to give a lecture; there he first met Wilfred Cantwell Smith, who later became a mentor and friend. They became lifelong supporters of each other on the study of world religions, particularly religious pluralism.

It was also during this period that Hick published his first book, Faith and Knowledge (1957), that he had already prepared to publish in Great Britain but had not been successful. Hick also published a significant article on Christology, “The Christology of D. M. Ballie,"48 in the Scottish Journal of Theology while he was at Cornell. What Hick did in this article was to criticize the Scottish theologian Donald Baillie’s Christology. ${ }^{49}$ Hick admits that at the time he expressed his orthodox version of

${ }^{46}$ Ibid., 104.

47 Ibid.

48 John Hick, “The Christology of D. M. Baillie,” Scottish Journal of Theology 11, no. 1 (Mar. 1958): 1-12.

49 Douglas McCready, “The Disintegration of John Hick’s Christology,” Journal of the Evangelical Theological Socieity 39, no. 2 (June 1996): 259. In McCready's words, "He said that while Baillie sought to remain orthodox, he tended to understate Christ's deity. Hick accused Baillie of teaching a degree Christology and adoptionist Christology. ... Hick emphasized that Jesus is different in kind, not merely in degree, from other humans” (ibid.). 
Christian faith in his article. Hick began departing from Chalcedonian orthodoxy in his criticisms on Donald Baillie's famous book, God Was in Christ. ${ }^{50}$ There was not a big change in his view of Christianity while teaching at Cornell.

\section{Princeton Theological Seminary (1959-1964)}

After Hick’s three years at Cornell ended, both McGill and Princeton Theological Seminary were interested in calling him. He accepted the call to teach at Princeton Theological Seminary beginning in the summer of 1959. At that time he considered himself to be a conservative theologian who could teach in a seminary where ministers were being trained. However, as the chapter title of his autobiography_- "Heretic at Princeton Seminary"-implies, his experience there turned out to be rather unpleasant. With some regrets Hick recalls his experience then and expresses his mixed feelings as follows:

The Seminary regarded me as soundly conservative in my theology, as indeed I thought I was - otherwise I would have opted without hesitation for Union or McGill, both of which were much better environments for free thinkers. However it turned out before long that I was not conservative enough. But this was the largest and leading Presbyterian seminary in the country with a number of firstrate scholars on its faculty; Princeton was a very attractive town with a great university and excellent schools, the Seminary's offer was generous - and we went there. ${ }^{51}$

With its almost one-and-a-half-century history, Princeton Theological Seminary then was the largest theological school in the American Presbyterian Church, with over five hundred students. Hick's position was professor of Christian philosophy. From the first lecture Hick argued that there is no Christian philosophy while there are Christian

\footnotetext{
${ }^{50}$ Hick, John Hick: An Autobiography, 116.

${ }^{51}$ Ibid., 119.
} 
philosophers. Hick basically taught the philosophy of religion in his class, along with some seminars on the issue of evil, God's love, and Paul Tillich's ideas. ${ }^{52}$

As is the custom in the Presbyterian Church, Hick as a Presbyterian minister applied to join the Presbytery of New Brunswick. ${ }^{53}$ Interestingly, the chair of the committee which made the final decision about the applications was Clyde Henry, "a disciple of J. Gresham Machen, author of The Virgin Birth of Christ (1930)"54 whose theological position was very conservative. Of course Henry's theological position was in agreement with his mentor's, and he asked Hick's opinion about the Westminster Confession (1647). Hick's opinion about it was that though theologically conservative, it was completely out of date. He describes how he answered as follows: "I mentioned the literal interpretation of the first two chapters of Genesis-the six days creation of the world, and Adam and Eve's eating of the forbidden fruit in the Garden of Eden,- -and then the doctrine of double predestination to heaven and hell, and eventually arrived at the virgin birth of Jesus, which I did not deny but did not affirm and did not regard as essential to the central doctrine of incarnation, which I did affirm." ${ }^{55}$ Hick shows his distinction between the several teachings that he did not affirm and one that he did affirm in this answer.

52 Ibid., 122.

${ }^{53}$ Unless he was accepted by the Presbytery, he would be stripped of his professorship, for all professors in the Seminary must be ministers of the United Presbyterian Church.

${ }^{54}$ Hick, John Hick: An Autobiography, 124. Machen’s position was much more conservative than Princeton itself, so that he founded his own Westminster Seminary in 1929. See ibid., 125.

55 Ibid. 
Though Hick did not deny them, there was a sign of departure from the traditional teachings of Christianity. He still showed his conviction in regard to the doctrine of incarnation because he calls it "the central doctrine of incarnation.” What Hick was not sure of and did not affirm was only one aspect of Christian theology, according to him, namely the virgin birth of Jesus. He expressed his view on the issue of the virgin birth of Jesus in the second of two presbytery meetings at which this subject was discussed. He made himself clear on the virgin birth of Jesus while generally accepting other traditional Christian doctrines. He described it as follows:

Now a word specifically about the virgin birth of our Lord. Left to myself I do not have anything to say about this at all—and in this, as the ministers here will certainly know, I am following the example of the majority of the New Testament writers: Paul, John; Mark, Peter, James and Jude all believe in Christ as the Word Incarnate, but none of them mentions the idea of a virgin birth; and I am content to follow them in this. However, if I am specifically challenged to say something about it, I have to say simply that I do not affirm it; it plays no part in my personal faith. I do not assert that it is impossible, or that it may not be true; and I have no quarrel with those who do affirm it; but I am not myself able to affirm it. ${ }^{56}$

Though his answer was satisfactory to most members of the Presbytery and he was received as a member of the Presbytery at that meeting, his reception by the Presbytery was rescinded later through the influence of Henry and others who were against him. However, after a long period of debate between both parties, ${ }^{57}$ even getting the attention of the press, the Judicial Commission of the General Assembly (Denver, May 1962) finally made the decision that the designating of specific doctrines as essential and necessary was discountenanced. Hick and his supporters won the controversy. His theological position on the issue of the virgin birth, whether it was an essential and

${ }^{56}$ Ibid.

${ }^{57}$ People were divided into two groups: there were those who supported Hick and his view on the issue; there were others who thought Hick was against the traditional doctrines of Christianity. 
necessary doctrine to the system of Presbyterian doctrine, particularly to the Incarnation, was "the first noticeable departure" ${ }^{\text {58 }}$ from traditional Christian doctrine. He even claimed that he made some contributions to his mother church in her doctrinal development and said: "The Presbyterian church had taken a tiny step in the direction of credibility in the modern world." 59

\section{Cambridge University (1963-1967)}

Hick’s move to Cambridge happened through a Guggenheim Fellowship during the 1963-64 academic year to write his new book on the philosophical problem of evil. As a result, his Evil and the God of Love was published by Macmillan in London and Harper \& Row in the States in 1966, revised in 1977, and reprinted in 1978, 1979, 1985, and 2001. This book became one of the classics on the problem of evil and the issue of theodicy, and caused a great amount of discussion.

In this book, Hick tried to compare the traditional Augustinian answer to the problem of evil with that of the Irenaean model. Hick argued that the idea that evil is a privation of good rather than some kind of reality was a concept Augustine received from the Neo-Platonists. ${ }^{60}$ According to the Augustinian model, Hick states, "Evil was not a reality in its own right but the going wrong of something good—as blindness is not anything positive but something negative, a lack of the proper functioning of the eye, which in itself is good. Thus evil has not been created by God who is therefore not

\footnotetext{
${ }^{58}$ Hick, “A Pluralist View,” 32.

${ }^{59}$ Hick, John Hick: An Autobiography, 130.

${ }^{60}$ Ibid., 133.
} 
responsible for it.”61 To Hick the idea of evil as a privation of good was logically invalid as well as incoherent. The basic argument was that a wholly good creation going wrong would be a self-contradiction. The creator of the entire universe would be ultimately responsible for his creation and its outcome whatever they are, including evil itself.

As a better alternative, Hick chose the Irenaean model of the problem of evil. According to Irenaeus, there were two stages in the creation of human beings. Irenaeus distinguished the concepts between "image” and "likeness" of God in the creation of humans in Gen 1:26. God created humans in the "image” of God at first, but not in the "likeness" of God yet. In the first stage of creation, humans were created as intelligent and ethical beings, but it was in the second stage of creation that they would be created into his likeness as children of God through their own choice. Stretching this understanding of Irenaeus to its furthest extent, Hick developed his own hypothesis that the ideal state of humans is not found in the Garden of Eden in the past but it is found in the future when they reach an ultimate good. The publication of Evil and the God of Love was the major event during Hick’s stay at Cambridge; there was no noticeable move toward pluralistic thought during his stay at Cambridge.

\section{Birmingham University (1967-1982)}

During the third year at Cambridge, which was the last year for the initial appointment before a tenure appointment until retirement, Ninian Smart moved from the H. G. Wood chair at Birmingham to start the new Religious Studies department at Lancaster, and Hick applied for the vacant chair. In 1967, Hick moved to Birmingham

61 Ibid. 
University and was appointed as a chair, which would gave him a greater freedom. ${ }^{62}$ It was during his fifteen years at Birmingham that Hick began to develop his theory of religious pluralism. The city of Birmingham was the perfect soil for religious pluralism because it had been "a multicultural, multiracial and multireligious city." ${ }^{63}$ Briefly describing the city of Birmingham, he said:

This city, in the middle of England, is an industrial center, which was one of the main receivers of immigration during the 1950s and 1960s from the Caribbean islands and from the Indian subcontinent. There was thus a sizable presence of several non-Christian traditions, consisting of the new Muslim, Sikh, and Hindu communities, as well as a small but long-established Jewish community; subsequently there have come to be several Buddhist groups. Immigration was then a hotly debated issue, and the neo-Nazi National Front was active in the area, generating prejudice and hatred and promoting violence against black and brown people and against Jews. It was a challenging time and place in which to find oneself. ${ }^{64}$

As a city with many cultures, races, and religions, Birmingham provided him with an open view in regard to other religious faiths. Particularly Hick's encounters with other religious groups such as Muslims, Sikhs, Hindus, and Jews convinced him that his Christianity-centered view of religion was narrow-minded and he needed to have a pluralistic view of religions. In 1969, having met with them and even attended their worship services as chair of the religious education panel in the Community Relations Committee (CRC), Hick expressed his feelings about them and said:

As I spent time in the mosques, synagogues, gurudwaras and temples as well as churches something very important dawned on me. On the one hand all the externals were different. In a Hindu temple, for example, the sights, the sounds, the smells, the colours were those of India and I could imagine myself (after I had been in India) back there. And not only the externals, but also the languages, the concepts, the scriptures, the traditions are all different and distinctive. But at a

${ }^{62}$ Ibid., 141, 142.

${ }^{63}$ Hick, Problems of Religious Pluralism, 1-4; Nah, "A Critical Evaluation of John Hick’s Theology of Religious Pluralism,” 35.

${ }^{64}$ Hick, “A Pluralist View,” 37. 
deeper level it seemed evident to me that essentially the same thing was going on in all these different places of worship, namely men and women were coming together under the auspices of some ancient, highly developed tradition which enables them to open their minds and hearts 'upwards' towards a higher divine reality which makes a claim on the living of their lives. They are called, in the words of a Hebrew prophet, 'to do justly, to love mercy, and to walk humbly before their God.' At this basic level the religions are at one. ${ }^{65}$

Hick, on a practical level, must have already been moving in the direction of religious pluralism, which he began to develop in the later period. I am not sure whether this was what he felt then, because the description of the experience there was written about three decades later. It was during this early period of his stay at Birmingham when he had active encounters with other religious groups that the religious pluralism was being conceived on a practical level.

He was strongly interested in interreligious dialogues as well as in establishing community relations organizations that would act against social injustice and cultural and religious conflicts between religions. For example, he was involved in establishing "All Faiths for One Race” (AFFOR), which was originally formed to protest against the allWhite South African Cricket team planning to arrive in England, and continued as an organization to deal with the injustices of racism due to racial, cultural, and religious misunderstanding. "All Faiths for One Race" ${ }^{, 66}$ was an independent activist organization, of which he was one of the founders and the first chair, ${ }^{67}$ while the Birmingham Community Relations Committee was government-sponsored. Another time, Hick's activist spirit made him propose "the creation of a Birmingham Inter-Faiths Council, and

${ }^{65}$ Hick, John Hick: An Autobiography, 160, 161.

${ }^{66}$ By “One Race” Hick means "the human race.”

${ }^{67}$ Hick, John Hick: An Autobiography, 171. 
this was created in January 1975." ${ }^{68}$ Hick was chosen as its first chairman, and five religious groups, Hinduism, Chrisitianity, Islam, Judaism, and Sikhism were included. ${ }^{69}$ While Hick was at the University of Birmingham for fifteen years, he not only had several opportunities to meet with other religious groups and to be exposed to their faiths, but he also had chances to visit India (Hinduism), ${ }^{70}$ Punjab (Sikhism), ${ }^{71}$ and Sri Lanka (Buddhism), ${ }^{72}$ where he was able to encounter their faiths in their historic context. During this period Hick was deeply involved in the interreligious activities which made him not only conceive the thoughts in regard to religious pluralism, but give birth to the theology of world religions and mature religious pluralism in his later period there.

Though being deeply active in various interreligious dialogues and activities, Hick was not at all unproductive in his academic activities. During his stay at Birmingham, Hick never stopped writing and publishing books and articles. ${ }^{73}$ It was during this period that his coedited book with Michael Goulder The Myth of God Incarnate $^{74}$ came out. By the time Hick edited this book he had been exposed enough to

${ }^{68}$ Ibid., 168.

${ }^{69}$ Hick, “A Pluralist View,” 37; idem, John Hick: An Autobiography, 168.

${ }^{70}$ Hick, John Hick: An Autobiography, 193-205.

${ }^{71}$ Ibid., 206-216.

${ }^{72}$ Ibid., 217-226.

${ }^{73}$ He lists the books that he wrote and published as follows: "During the fifteen years at Birmingham I published Christianity at the Centre (in later versions The Centre of Christianity and then The Second Christianity), Arguments for the Existence of God, God and the Universe of Faiths, Death and Eternal Life, God Has Many Names, Problems of Religious Pluralism, Why Believe in God?. . a as well as numerous articles and book reviews" (ibid., 158).

${ }^{74}$ Hick, ed., The Myth of God Incarnate. See also Michael Green, ed., The Truth of God Incarnate (London: Hodder \& Stoughton, 1977); John A. T. Robinson, review of 
other faiths that they made a great impact on his journey as a philosopher who viewed the world from the Christian perspective. Hick came to see that the central problem between Christianity and other religions hinged on the doctrine of the incarnation. If Jesus was God the son, Christianity must be superior to all other religions and be the only route for salvation. Investigating this central doctrine of the incarnation, Hick tried to take a closer look at the traditional doctrine and its history. The basic thesis of his argument was that "the Jesus of history" is not the same as "the Christ of faith.",75 There was a gradual deification of Jesus going on in the history of the Church. Hick claimed that "it was not the Jesus of history but the Christ of the faith as officially defined at Nicea (325 CE) and Chalcedon (451 CE) who proclaimed himself as sole savior of the world.”76

In "Jesus and the World Religions,” the concluding chapter of The Myth of God Incarnate, Hick insisted that since the dogma of the incarnation is only "poetry . . . hardened into prose” and “a metaphorical son of God” escalated to “a metaphysical God the Son." 77 Hick's basic thesis in the book was that "the language of divine incarnation, in which we speak of Jesus as God incarnate, God the Son, Son of God, Second Person of the Trinity living a human life, is symbolic, mythological, or poetic language.»78

The Myth of God Incarnate-The Truth of God Incarnate, by John Hick and Michael Green, Journal of Theology for Southern Africa 21 (Dec. 1977): 67-71.

${ }^{75}$ Hick, John Hick: An Autobiography, 228.

76 Ibid.

${ }^{77}$ Hick, ed., The Myth of God Incarnate, 177.

${ }^{78}$ Hick, John Hick: An Autobiography, 231. The meaning of myth in the entire book is not clear enough. Wiles never defines it, while borrowing from Strauss's Life of Jesus (1835): "a doctrine expressed in a narrative form, an abstract moral or spiritual truth dramatized in action and personification" (Hick and Goulder, eds., The Myth of God Incarnate, 153). Myth is, thus, as George H. Tavard suggests, "not to be believed, although it may at times help to confess the faith" (George H. Tavard, "The Myth of God Incarnate,” Theological Studies 39, no. 1 [Mar. 1978]: 164). 
Therefore, Hick argues, Christians should not insist that Christ is the only way for salvation, and thus Christianity is only one among many religions.

\section{Claremont Graduate University (1978-1992)}

In 1978 while he was attending a conference held in San Francisco, Hick was asked to give a lecture at the Claremont Graduate School near Los Angeles. After that, he was invited to occupy the position of Danford Professor of the Philosophy of Religion, which was going to be vacant. He accepted this offer, and in the following three years he taught only in the spring semesters and returned to Birmingham for the rest of the year until he and his wife moved to Claremont in $1982 .{ }^{79}$ Hick was attracted by Claremont Graduate University for two reasons. First, he was delighted that he could teach only graduate students at CGU, whereas he had to teach mostly undergraduate students before. Second, he liked the academic climate in the United States, which was "much more open and enquiring than in Britain.” ${ }^{80}$ Another reason that he enjoyed CGU is that while Birmingham was a secular university where the philosophy of religion occupied a marginal place, the religion program at CGU took a central position.

Hick was deeply involved in organizing numerous "philosophy of religion conferences” nationwide as well as internationally. Through being involved and arranging these conferences he was able to meet several leading authorities in their areas, such as Wilfred Cantwell Smith from Harvard, Muhammed Arkoun from the Sorbonne,

${ }^{79}$ Hick, John Hick: An Autobiography, 250.

${ }^{80}$ Ibid., 259. 
Takeuchi Yoshinori from Kyoto, and Zwi Werblowsky from the Hebrew University, Jerusalem. $^{81}$

The Claremont Graduate University was one of the best soils for his still growing idea of a pluralistic hypothesis in religions to be fully matured to its maximum potential. His seminars, teachings, and life at CGU were all melded together in his most comprehensive book on the study of religion, An Interpretation of Religion, ${ }^{82}$ which was published in 1989 by Macmillian and Yale University Press and won the Grawemeyer Award in Religion in $1991 .^{83}$ He sums up his book as follows:

This is a fairly comprehensive book, arguing for the rationality of basing beliefs on religious as well as sense experience; noting the subjective contribution to all conscious experience, so that religious experience takes different forms within different religio-cultural traditions; and suggesting that in order to make sense of this variety, we have to postulate an ultimate ineffable (or transcategorial) Real whose universal presence is humanly experienced in these different ways. This is my "pluralistic hypothesis.” 84

Hick remarked that his presence there made it possible for him to write his book An Interpretation of Religion and said: "I am not sure that I would have been able to write this if I had not gone to Claremont with its pervasive spirit of openness to the global reality of religion. At any rate it was here that I developed my 'pluralistic hypothesis'

${ }^{81}$ Ibid., 253.

${ }^{82}$ His An Interpretation of Religion is a summary of his academic life there at CGU; he said: "During my time at Claremont I offered seminars on the epistemology of religion; the problem of evil; death and eternal life; contemporary philosophies of religion; Locke, Berkeley and Hume; Christianity and other religions; Buddhism and Christianity (with Masao Abe); and the entire draft of what became my book $A n$ Interpretation of Religion" (ibid., 259).

${ }^{83}$ Ibid., 269. He received an award of $\$ 150,000$ then.

${ }^{84}$ Ibid., 283. 
about the relation between the religions.” ${ }^{85}$ As a matter of fact, his presence at CGU had a major impact on his career as a philosopher of religion.

Along with several other scholars whom he met, Wilfred Cantwell Smith was a major influence in his career and became a good friend and mentor. Smith was a leading scholar in comparative religion whose specialization was in Islam. ${ }^{86}$ His contribution particularly in the history of religions was deeply influential, because it rejected the idea that Christianity was the only true religion and way of salvation, which has been proposed and widely recognized. In that sense, as Hick calls him, Smith was "the father of contemporary religious pluralism.”,87

It was also due to his influence that Hick saw the religious traditions as "not static entities but living movements.” And he adds, "they are not tightly homogeneous but have each become in the course of time internally highly various." 88 That is why, he insists, as there are large differences between Christianity in the first century and Christianity today, so are Buddhism, Islam, and Hinduism in their early stage and in the later stage. As Hick observes, Smith "traces the development of the concept of a religion as a distinct and bounded historical phenomenon." ${ }^{89}$ It is from this idea that Hick must have drawn the concept of "religious traditions," which shows the movement and ongoing progress rather than static “religions.”

${ }^{85}$ Ibid., 259.

${ }^{86}$ Ibid., 259-260.

${ }^{87}$ Ibid., 261.

${ }^{88}$ Frank Whaling, ed., The World's Religious Traditions (New York: Crossroad, 1986), 149.

${ }^{89}$ John Hick, "The Reconstruction of Christian Belief for Today and Tomorrow: 2,” Theology 73, no. 603 (Sept. 1970): 400. 
Since his retirement in 1992 at the age of seventy, Hick has been still deeply productive in writing books and articles and giving lectures. He not only teaches as "an emeritus professor of both Birmingham University UK and the Claremont Graduate University, California,” but is actively involved in other activities under titles such as "a Fellow of the Institute for Advanced Research in Arts and Social Sciences, University of Birmingham UK, and a Vice-President of the British Society for the Philosophy of Religion and of the World Congress of Faiths.” 90 Though he is retired officially from the University, he never stops being a teacher, philosopher, and social activist.

\section{Personal Journey: From Theologian to Philosopher}

Having looked at John Hick’s biographical background diachronically, it is time to look at him from a slightly different angle. In the previous sections Hick’s life has been examined and described in three dimensions on the basis of historical development. From here on, I will look at Hick’s life and analyze and synthesize it in two aspects, mostly on the basis of the biographical background that has been covered. First, in this section, Hick's personal pilgrimage from a theologian to a philosopher will be the focus, discussed in two parts. Second, in the next section, Hick's view of Scripture, which he presupposes as a theologian, will be discussed.

\section{Early Hick: The Theologian}

For practical reasons, I have divided Hick’s life into two parts: (1) an early Hick - the theologian; and (2) a later Hick — the philosopher. On the basis of information provided in the previous sections, in this section I will see how his life pilgrimage

${ }^{90}$ Hick, John Hick: Philosopher of Religion and Theologian. 
progressed and changed decade by decade as a theologian from the right (the evangelical) to the left (the liberal). This section will include the period from the 1940s to the 1960s.

\section{The Evangelical Period (to 1940s)}

Hick was born and raised in a traditional Anglican Church like average English children of the time. During his childhood, including his early teen years, though he was not very excited about the religious activities in the church, as he recalled his life he said that he had "a rather strong sense of the reality of God as the personal and loving lord of the universe, and of life as having a meaning within God's purpose." ${ }^{91}$ In other words, even before his conversion he believed in "absolutely some sort of divine reality, though not the God of Christian orthodoxy." ${ }^{92}$ This sense of God's presence in life must have been a prevailing experience throughout his life as a theologian as well as a philosopher, which would be a theological foundation for his religious pluralism.

At the age of eighteen, while studying law at University College, Hull, Hick had a strong evangelical conversion experience that happened forty-two years before 1982 and he still remembered clearly. ${ }^{93}$ Hick described the excitement of that experience which happened "on the top deck of a bus in the middle of the city of Hull" as follows: "It was as though the skies opened up and light poured down and filled me with a sense of overflowing joy, in response to an immense transcendent goodness and love. I remember that I couldn't help smiling broadly—smiling back, as it were, at God.”94 This experience

${ }^{91}$ Hick, God Has Many Names, 14.

${ }^{92}$ Hick, John Hick: An Autobiography, 33.

${ }^{93}$ Ibid., 34.

${ }^{94}$ Michael Goulder and John Hick, Why Believe in God? (London: SCM, 1983), 40-41. 
of the ultimate divine Reality and an "evangelical conversion under the impact of the New Testament figure of Jesus,"95 Hick insists, became possible through the circumstances available to him at that time. According to him, he happened to have this conversion experience into Christianity because his "closest friends at Hull were members of the InterVarsity Fellowship, the evangelical campus organization.”96

In this context, Hick came to accept what he calls "the entire fundamentalist theological package” without hesitation, as mentioned earlier. To him, the Bible was true and its teachings were literal and historical. I would call this period "the evangelical period” because during this time Hick was almost a fundamentalist who accepted all the claims of the Bible as true, just as other evangelical Christians believed.

This dramatic conversion experience completely changed his life direction from law to Christian ministry. Of course, since he was a member of the InterVarsity Fellowship, which then had a strong affiliation with the Presbyterian Church of England, Hick intended to do Presbyterian ministry. Hick remained as what he loved to call an “evangelical fundamentalist” for the rest of his time at Hull and the first year at Edinburgh. ${ }^{97}$ During that first year, Hick was deeply involved in the activities of the Christian Union, “attending virtually all its Bible studies, prayer meetings, and talks.”98

When war broke out, he served in the Friends Ambulance Unit as a conscientious objector on the basis of Christian conviction that Jesus was against the mass violence of war. This evangelical type of Christianity in Hick’s life must have been dominant even

${ }^{95}$ Hick, “A Pluralist View,” 29-30.

${ }^{96}$ Hick, John Hick: An Autobiography, 34.

97 Ibid.

${ }^{98}$ Hick, God Has Many Names, 15. 
after the war, though there was a sign of departure from the "biblical fundamentalism." When he returned from the war, at Edinburgh he stayed away from the Christian Union, but he still continued to be theologically conservative. His experience in war and philosophical training must have made some major impact on his life to raise "awkward questions"99 as follows: "Could one understand the sun standing still for about a day as recounted in Joshua 10:13?” “Can biological evolution responsibly be rejected just because it is contrary to the book of Genesis?" "Does the infinite love of God go well with eternal torment in hell?" "Are there," he insisted, "not innumerable contradictions between this biblical text and that?” ${ }^{100}$ Though there were some signs of change in his theological position, he did remain "a very conservative Christian"101 during his school years at Edinburgh and Oxford.

\section{Philosophical Turn to the Pluralistic Thinking (1950-1960s)}

In the beginning of the 1950s, Hick started his theological training to be a minister at Westminster Theological College, Cambridge. During this period at Cambridge, Hick still showed his orthodox views in Christian theology. For example, there he remembers "being profoundly shocked by a graduate student who argued that Jesus was not God incarnate but a remarkable human being." ${ }^{102}$ This experience shows that his Christology, in general, must have been still conservative and orthodox.

\footnotetext{
${ }^{99}$ Hick, John Hick: An Autobiography, 70.

100 Ibid.

101 Ibid.

102 Hick, “A Pluralist View,” 32.
} 
After a strong fundamentalist Christian period, Hick’s pilgrimage as a theologian and philosopher really began to take place during his teaching career. As noted above, Hick started his career as a minister of a local Presbyterian church in Northumberland, near Scotland. Hick began his ministry along with his married life there in Belford Church. He stayed there two and a half years, preaching two sermons every week. His sermons, he insists, “are biblically based." ${ }^{103}$ Nothing particular on his theological view is noticed during this period.

Hick began his teaching career at Cornell University as a professor of the philosophy of religion. During his Cornell years, Hick remained a conservative theologian and published an article criticizing the Scottish theologian Donald Baillie’s Christology in Scottish Journal of Theology, showing his still conservative views on Christology.

However, as the title of the chapter in his autobiography "Heretic at Princeton Seminary” implies, Hick had a bitter experience while he was at the Princeton Theological Seminary, which shows a minor but sure turn toward pluralistic thinking. As a professor of the Seminary, he needed to have his ministerial credentials transferred from England to the United States. He was asked if there was anything in the Westmister Confession of 1647 to which he took exception. He admitted that some articles he did not affirm and did not regard as essential to the central doctrine of incarnation, including "the literal interpretation of the first two chapters of Genesis,"104 “the predestination of many to eternal hell, the verbal inspiration of the Bible, and the virgin birth of Jesus.” ${ }^{205}$ The

\footnotetext{
${ }^{103}$ Hick, John Hick: An Autobiography, 92.

${ }^{104}$ Ibid., 125.

${ }^{105}$ Hick, Problems of Religious Pluralism, 2.
} 
majority of the New Testament writers, he insists, admit that Christ was the Word Incarnate, but "none of them mentions the idea of a virgin birth.”" ${ }^{106}$ His agnosticism centered upon the last point: “The virgin birth of Jesus” was a beginning sign of his drift from evangelical Christianity. His point was that his agnosticism in regard to the doctrine of the virgin birth of Jesus did not hurt the affirmation of the "central Christian faith in the incarnation.”107

Having taught in universities in the United States for over eight years, Hick returned to England, teaching as Lecturer in Divinity at Cambridge University. He remained as a Lecturer there for three years from 1964 to 1967. There he published his Evil and the God of Love (1966), which became one of the classics in that area of study. He advocated the "Irenaean theodicy" (soul-making theodicy), while arguing against the traditional Augustinian model with its emphasis on the doctrine of the original sin that humans inherited from the first parents after the fall. The Irenaean theodicy laid a foundation for the later development of an eschatological model, ${ }^{108}$ which will be dealt with in depth in following chapters.

One noticeable beginning of Hick's shift toward the left, though it was not a theological one yet, was observed in his article "Christology at the Cross Roads" published in Prospect for Theology in 1966. Discussing the nature of Christ and his uniqueness, Hick was inclined to say that Christ's uniqueness is “a uniqueness of

${ }^{106}$ Hick, John Hick: An Autobiography, 125.

${ }^{107}$ Hick, Problems of Religious Pluralism, 3.

${ }^{108}$ According to Hick's eschatological model, human life is not limited to this earth but will be continued over and over again in other worlds depending on their soulmaking status. 
degree”"109 rather than of kind as the traditional Christology claims. "He had one nature," he also insisted, "and this nature was wholly and unqualifiedly human." ${ }^{110}$ In other words, Jesus must be fully human yet different "in degree of human possibility, such as faith, obedience to God, or openness to divine grace.”111 This was a sign that Hick was taking another step toward an end to his identification with orthodox Christianity.

In 1967, Hick moved from Cambridge to Birmingham University to acquire the chair of H. G. Wood Professor in the Theology Department. He preferred a position with more academic freedom to a university with a high reputation. This move to Birmingham made a dramatic change in Hick's career as a theologian and philosopher. During this period, Hick’s pluralistic theology of religions, as Hick himself remarks, did come as a result of many interrelated factors that he encountered. First, based on his Irenaean theodicy proposed in his recent book Evil and the God of Love (1966), the idea that the good God would not destroy the majority of human beings but rather save them all eventually paved the way to arrive at his pluralism in the near future. Second, as Hick himself said, his move to the multicultural, multiracial, and multi-religious city of Birmingham as well as what he calls "race relations" and "community relations" contributed to his pluralistic hypothesis of world religions. ${ }^{112}$ Third, Wilfred Cantwell Smith's book, The Meaning and End of Religions (1962), which presents the "convincing

109 John Hick, "Christology at the Cross Roads," in Prospect for Theology, ed. F. G. Healey (London: James Nisbet, 1966), 140. Here Hick called it a "Degree or NeoArian Christology.” As Eddy noted, Hick presented the "agape incarnational Christology” (Eddy, “John Hick’s Pluralist Philosophy of World Religions,” 112).

${ }^{110}$ Hick, "Christology at the Cross Roads," 164.

${ }^{111}$ Ibid., 140.

${ }^{112}$ Hick, God Has Many Names, 17. 
critique of the concept of a religion and of the notion of religions as contraposed sociotheological communities," ${ }^{, 13}$ made a big impact on his development of religious pluralism. According to Smith, "A true relationship to God may occur in the lives of people in each of the great religious traditions." ${ }^{114}$ The final sign of his move to pluralistic theology is observed in his Christianity at the Center (1968), which rejects the orthodox system of belief such as "the infallible inspiration of the scriptures, or the fall of man, or the virgin birth, or the bodily resurrection, or contra-natural miracles, or the sanctity of the church.”115

During this period Hick showed major changes from Orthodox Christianity to a more liberal one, and even to the beginning stage of the pluralist mode. However, he was not yet fully pluralistic in his theological approach, as will be discussed in the following section. John Hick, in this period, could be seen as a theologian or Christian philosopher rather than a philosopher or pluralist.

\section{Later Hick: The Philosopher}

John Hick was no longer a Christian theologian in a traditional sense, but a philosopher or religious pluralist, from the 1970s and onward. He was fully converted to religious pluralism and became a passionate advocate of it. In this section, I will divide Hick's life into two periods: (1) Pluralist from a Christian perspective (1970s); and (2) Pluralist from a Philosophical perspective (1980s-present).

\footnotetext{
113 Ibid., 18.

114 Ibid.

115 John Hick, Christianity at the Center (London: SCM, 1968), 16.
} 


\section{Pluralist from a Christian Perspective (1970s)}

On top of the three influences noted above that paved the way for Hick to advocate religious pluralism, in 1970 Hick was planning to "write a major work on eschatology," as D’Costa observed, "based on eschatological thought” on the major world religions. ${ }^{116}$ This project was reinforced by his trips to India (1974 and 19751976) and to Sri Lanka (1974), where he had real encounters with Hinduism and Buddhism and their doctrine of reincarnation. As a result, six years later Hick’s magnum opus in the global theology of eschatology, Death and Eternal Life (1976), was published and made available to all adherents of religion. In this book, the concept of his eschatological model called "pareschatology," which is a combination of the eschatologies from the Eastern and the Western religions, was proposed finally as a result of his theology of the "God" who is center of all.

However, in 1973, while he was still working on his global theology of eschatology, Hick published his first full-fledged pluralist book, God and the Universe of Faiths (1973), which was a compilation of articles. Also, for the first time, he presented the idea of a "Copernican revolution”117 in the theology of religions. Hick's selfdescribed Copernican revolution consisted of "a paradigm shift from a Christianitycentered or Jesus-centered model to a God-centered model of the universe of faiths.”118 The great world religions, he insisted, are different human perceptions of the same divine Reality due to the different historical circumstances. Hick, as Paul R. Eddy observes, tries to relegate "any theological position — from any religious tradition—-that attempts to

${ }^{116}$ D’Costa, John Hick's Theology of Religions: A Critical Evaluation, 13.

${ }^{117}$ Hick, God and the Universe of Faiths, 120-133.

${ }^{118}$ Hick, God Has Many Names, 18. 
maintain the superiority or normativity of its belief system over against those of other religions to the category of Ptolemaic theology." 119

Having launched a new paradigm shift from Church-centeredness or Christcenteredness to God-centeredness in regard to the world religions, Hick now faced some Christological questions. If Jesus, Hick argued, was literally God incarnate (the Son of God and one of the Trinity) and Christianity was founded by him, "it is then very hard to escape from the traditional view” that salvation is only available through Christianity because Jesus is the only way for it. ${ }^{120}$ Then, as he used to affirm, "the whole human race ought to be converted to Christianity.”121 The solution for this dilemma was well presented in his newly edited book Myth of God Incarnate (1977). As D’Costa suggests, "Hick argued that biblical criticism (and here he relied heavily on his co-contributors) and the evidence from other religions required a mythological, rather than literal, understanding of incarnational language.”122 As expected, this book caused major controversies among scholars as well as conservative Christians. The book argues that the historical Jesus did not claim to be divine, that incarnational doctrine is a result of the church's theologization, and that the incarnation story of Jesus is not to be taken literally, but rather mythologically. "If Jesus was literally God incarnate,” Hick argues, “and if it is by his death alone that men can be saved . . . then the only doorway to eternal life is

${ }^{119}$ Eddy, “John Hick’s Pluralist Philosophy of World Religions,” 56.

${ }^{120}$ Hick, God Has Many Names, 19.

${ }^{121}$ Hick, Disputed Questions in Theology and the Philosophy of Religion, 140.

122 D’Costa, John Hick's Theology of Religions: A Critical Evaluation, 15. As David S. Nah observes, "the metaphorical or mythic language of divine incarnation allows for a genuine acceptance of religious pluralism” (Nah, "A Critical Evaluation of John Hick’s Theology of Religious Pluralism,” 36). 
Christian faith.”"123 Therefore, Hick argues, "the Christian pluralist should see the idea of divine incarnation as a metaphorical rather than a literal idea.”124

During the 1970s, Hick still appeared to be developing the theology of pluralism from the Christian perspective. In other words, though developing the radical views of religions and religious pluralism, he was doing it as a Christian philosopher. His heavy use of Christian vocabulary—God, Jesus, Incarnation — was one of the sure evidences that his starting point was still Christianity.

\section{Pluralist from a Philosophical Perspective (1980s-Present)}

However, from the 1980s, Hick the philosopher began presenting his theory of world religions from a completely different perspective. As Eddy observes, whereas “prior to this, Hick had primarily ... defended his pluralist perspective from the vantagepoint of a Christian theology of religions," now, "Hick made the conscious attempt to develop a (tradition-independent) pluralist philosophy of religions.” ${ }^{125}$ As noted above, though the original move toward pluralism had started much earlier, his move to a radical pluralism began to take place in the 1980s.

For example, in 1980, Hick published his new book God Has Many Names, composed of several essays directed to a new approach of religious pluralism. Here, our own religion, he claimed, is not the only one but only "one of several—Buddhism, Islam, Hinduism, Judaism, Christianity, and so on.”126 Thus, Hick added, “we have been like a

${ }^{123}$ Hick, God Has Many Names, 180.

${ }^{124}$ Hick, Disputed Questions in Theology and the Philosophy of Religion, 144.

${ }^{125}$ Eddy, “John Hick’s Pluralist Philosophy of World Religions,” 60.

${ }^{126}$ Hick, God Has Many Names, 41. 
company of people marching down a long valley ... unaware that over the hill there is another valley, with another great company of people marching in the same direction ... ; and over another hill yet another marching group-each ignorant of the existence of the others.”127 This metaphor implies that every religion is in illusion that each one is the only group going to the final destination, yet everyone is on the right track.

On answering to the commonly asked question on the phenomenal multiplicity of God, Hick presents his own solution by adopting Kant's distinction between noumenon and phenomenon. There are, Hick suggests, "the single divine noumenon, the Eternal One in itself" and "the plurality of divine phenomena, the divine personae of the theistic religions and ... of the Absolute in the nontheistic religions.” ${ }^{228}$ This distinction between noumenal God and phenomenal God is a philosophical answer to the multiplicity of god. Therefore, Hick insists, as his book title God Has Many Names suggests, God has not only many names but many faces as perceived by the different religions. He concludes the article "God Has Many Names” as follows: “I mean that the Eternal One is perceived within different human cultures under different forms, both personal and nonpersonal, and that from these different perceptions arise the religious ways of life which we call the great world faiths." ${ }^{129}$ According to him, the great world religions are basically the finite “different human perceptions” of the infinite Eternal One, or the Real. ${ }^{130}$

Hick’s move to Claremont in 1982 made him even more devoted to his already growing religious pluralism and helped it mature into the pluralistic hypothesis.
${ }^{127}$ Ibid.
${ }^{128}$ Ibid., 53.
129 Ibid., 59.
130 Ibid., 114. 
Claremont was the perfect place where he could interact with other religions in the context of the East and West interaction. As Danforth Professor of the Philosophy of Religion at Claremont Graduate University, Hick did have the opportunity to organize numerous conferences and lectures. Also, two of his colleagues, the process theologian John Cobb Jr. and the Buddhist scholar Masao Abe, gave him a chance to refine and clarify his pluralistic hypothesis.

In 1987, Hick published Myth of Christian Uniqueness, another monumental contribution to his pluralistic hypothesis, as a result of a conference held under the auspices of the Blaisdell Lecture Series at Claremont planned by Hick and Paul Knitter. It was a compilation of twelve essays which showed its strength, getting a consensus from other Christian theologians_- "Protestant and Catholic, female and male, East and West, First and Third World.”131 The principal gain of this publication was that Hick found strong fellow scholars and advocates of religious pluralism from all over.

The year 1989 saw the publication of Hick’s magnum opus on the pluralistic hypothesis: An Interpretation of Religion, an expanded version of his prestigious 1986-87 Gifford Lectures at the University of Edinburgh. This book no doubt is one of the most comprehensive and most refined volumes among Hick’s books on religious pluralism. As Eddy notes, “the major philosophical and religious issues to which Hick has devoted himself over the years” are available in this “comprehensive interpretation of religion."132

131 John H. Hick and Paul F. Knitter, eds., The Myth of Christian Uniqueness: Toward a Pluralistic Theology of Religions (Maryknoll, NY: Orbis Books, 1987), viii.

132 Eddy, “John Hick’s Pluralist Philosophy of World Religions,” 64. 
Though he was officially retired from full-time professorship at Claremont in 1993, Hick has never retired from his rigorous writing and lecturing. He has published a number of books since then, clarifying and refining his theory of world religions. Now in his late eighties, Hick is still refining his thoughts through writings and lectures.

In this section, I have sketched Hick’s personal pilgrimage from a theologian to a philosopher, from an evangelical Christian to a pluralist religionist. The question is: What made this dramatic change in his life from a fundamentalist Christian to a pluralist philosopher of religion? The issues related to this question will be discussed in the following section, because a theologian's change in theological position relies, in part, on how he or she views the Scripture.

\section{Hick's Starting Point: Views of Scripture}

Here I examine Hick’s views of Scripture, which reveal his theological presuppositions. How he viewed the Scripture made the whole difference in his theology and theories of world religions. Thus it is crucial to look at his views of Scripture to understand his theological starting point. For example, his interpretation of the first two chapters of Genesis formed his view of man and his destiny, ${ }^{133}$ so that it made a great impact on his whole system of theology.

\section{Theological Presuppositions}

The religious pluralism of John Hick must be seen and analyzed in his life-long struggle with Christian theology and its relationship with other world religions. As noted earlier, he began his theological journey as an extremely conservative-what Hick calls fundamentalist—Christian following his powerful conversion experience. During his

${ }^{133}$ Hick, Death and Eternal Life, 46-48. 
early teaching career, some theological changes began to take place gradually. First of all, while Hick was at Princeton Theological Seminary, he began to question some Christian doctrines such as "the six days creation of the world, and Adam and Eve's eating of the forbidden fruit" in Gen 2, and "the doctrine of double predestination" and "the virgin birth of Jesus." ${ }^{134}$ Even before Hick published his radical book on religious pluralism, God and the Universe of Faiths (1973), he already showed his list of Christian doctrines that were "either quite untenable or open to serious doubt" ${ }^{135}$ as follows: divine revelation, creation ex nihilo, original sin, atonement, virgin birth, miracles of the Bible, resurrection, regeneration, heaven and hell. However, these were only a beginning compared with his complete rejection of the historicity of the Bible through mythological interpretation.

What are the factors that caused those gradual and eventually dramatic changes in his theological position? Hick's major concern in doing his theology seemed to focus on two factors: (1) His concern for "contemporary scientific knowledge”; (2) another concern for "the newly encountered fact of the other religions." ${ }^{136}$ Hick insists that theology is "an on-going activity in which the Church continually adjusts or (in times of rapid change) reconstructs”137 its doctrines. According to this principle, the theological

${ }^{134}$ Hick, John Hick: An Autobiography, 125. Particularly, as a Calvinist who emphasizes God's ultimate authority in the work of salvation, Hick's doubt of "the doctrine of double predestination" calls our attention. 339.

${ }^{135}$ Hick, “The Reconstruction of Christian Belief for Today and Tomorrow: 2,”
${ }^{136}$ Ibid., 341.
137 Ibid., 340. 
system can anytime be modified or reconstructed on the basis of the new discoveries of science or other religions.

First of all, though he seems to reject the naturalistic theory of the universe, namely naturalism, ${ }^{138}$ by claiming that "the naturalistic theory is incompatible with Christian belief,” ${ }^{139}$ Hick cannot escape being accused of founding his theological system on the basis of naturalism. For example, he adopted the basic presupposition of the liberal theology that "there is no conflict between science and religion." 140 Then Hick added, "There is in fact no point at which the theological claim clashes with scientific descriptions." 141 Problems, however, arise when they seem to clash with each other. For instance, when the six-day creation story seems to clash with modern scientific knowledge, ${ }^{142}$ it is interpreted as a myth rather than a historical and literal event. Thus,

${ }^{138}$ Hick mentions it briefly: “The accepted terms today are 'naturalism' and 'physicalism,' meaning the belief that the physical universe constitutes the totality of reality, no trans- or meta- or supra-physical or suprasensory reality such as the religions affirm. And so the entirety of reality is, at least in principle, fully describable and understandable by the empirical sciences” (John Hick, Science and Religion, http://www.johnhick.org.uk/article5.html, 2002 [accessed February 4, 2008]). See also Hick, “The Reconstruction of Christian Belief for Today and Tomorrow: 2,” 343. 343.

${ }^{139}$ Hick, “The Reconstruction of Christian Belief for Today and Tomorrow: 2,”

${ }^{140}$ Ibid. The presupposition of theological liberalism, Pierard insists, claims that "there is no inherent contradiction between the kingdoms of faith and natural law, revelation and science, the sacred and the secular, or religion and culture" (Richard V. Pierard, “Theological Liberalism,” Evangelical Dictionary of Theology, ed. Walter A. Elwell [Grand Rapids, MI: Baker Academic, 2001], 683). For more about theological liberalism, see Pierard, “Theological Liberalism,” 682-686. 343.

${ }^{141}$ Hick, “The Reconstruction of Christian Belief for Today and Tomorrow: 2,”

${ }^{142}$ For more about conflict between science and religion, see John W. Draper, History of the Conflict between Science and Religion (New York: Appleton, 1874); Andrew D. White, A History of the Warfare of Science with Theology in Christendom, 2 vols. (New York: Appleton, 1896). 
according to his reasoning, all Christian doctrines "must pass the tests of reason and experience, and one's mind must be open to new facts.” ${ }^{\prime 14}$ As a result, science or reason takes the place of revelation.

There is another concern that contributed in shaping Hick's theological system, "coming from the wider religious world." ${ }^{144}$ As a Christian theologian his gradual exposure to other religions such as Islam, Hinduism, Buddhism, and many others made continuous and eventually dramatic changes in his view of Christianity and other religions. Through his lifelong teaching career and experiences with other religions, he came to the conclusion that "Christianity represents one major historical strand among others." 145 "What we call a religion,” Hick insists, "as an empirical entity that can be traced historically and mapped geographically, is a human phenomenon.” Thus great world religions are human responses to the Divine, and are human creations.

These two factors radically reshaped Hick's Christian theology and its relationship with other religions. Thus, to Hick, theology is not "a body of divinely revealed truths" anymore, but "a continuing process of human reflection and theorizing aiming to clarify the meaning of man's religious experience." ${ }^{146}$ In this theological system the restriction to the religious data of a single tradition (an exclusive revelation) is not allowed. On the basis of these theological presuppositions, I now look at his views on certain issues of Christian doctrines.

${ }^{143}$ Pierard, “Theological Liberalism,” 683.

${ }^{144}$ Hick, "The Reconstruction of Christian Belief for Today and Tomorrow: 2," ${ }^{145}$ Ibid.
${ }^{146}$ Ibid., 402. 
Some Examples of Interpretation

On the basis of theological presuppositions mentioned above, I take a closer look at his views on certain issues of Christian doctrines. Among many other texts, two examplary cases that are crucial to traditional Christianity are included for discussion: the creation story of Genesis, and accounts of Jesus in the four Gospels.

\section{The Creation Story of Genesis}

As noted above, Hick already in 1970 included the doctrine of creation ex nihilo in the list of Christian doctrines that is "either quite untenable or open to serious doubt" in his article "The Reconstruction of Christian Belief for Today and Tomorrow."147 The literal understanding of the creation of the universe and humanity seems to have some obvious conflicts with modern scientific knowledge. Adopting the claims of natural science, in his Death and Eternal Life (1976), Hick affirmed the doctrine of a long-agecreation of life by God rather than the six-day creation of the Bible. He said:

We must assume that the picture being built up by the natural sciences of the origin of man, both individually and as a species, is basically correct and is progressively becoming more adequate and accurate as research continues. According to this picture, life on this planet began with natural chemical reactions occurring under the influence of radiations falling upon the earth's surface. Thus began the long, slow evolution of the forms of life, a process which has eventually produced man. And each human individual comes about through the partially random selection of a specific genetic code out of the virtually infinite range of possibilities contained even in the portion of genetic material lodged in his parents. ... And Christianity does not offer a different or rival account of our human origins. $^{148}$

${ }^{147}$ He began to question the probability of "the literal interpretation of the first two chapters of Genesis" while at Princeton Theological Seminary in the early 1960s (Hick, John Hick: An Autobiography, 125).

${ }^{148}$ Hick, Death and Eternal Life, 47. 
Hick calls the literal understanding of man’s creation in Gen 2 the “Hebraic myth of man’s genesis," ${ }^{149}$ which shows a spirit of contempt for the literal understanding of the Bible. Thus regarding the creation of human beings, he insists, "It has taken many hundreds of millions of years of biological evolution to produce him.”150 To Hick, the origin of life is not through God's supernatural act of creation as recorded in Genesis, but through the natural process called evolution. Yet, Hick considers himself "a creationist” in the sense that he believes that "the universe is God's creation,” and he believes that “God's creative work is progressive and continuous and that biological evolution is a part of it.”151 Accepting both creationism and evolutionism that God created the universe through the process of evolution, Hick can be called a theistic evolutionist. This is only one of many examples of how Hick views the teachings of the Bible.

\section{Accounts of Jesus in the Four Gospels}

As discussed earlier, Hick began doubting the literal and historical understanding of many accounts of Jesus in the four Gospels from the early stage of his teaching career. For example, he showed his doubt of the doctrine of the virgin birth of Jesus while affirming his incarnation, which he called "the central doctrine" ${ }^{152}$ during his stay at Princeton Theological Seminary. His view on Jesus' accounts became more liberal in his later article, “The Reconstruction of Christian Belief for Today and Tomorrow” (1970).

149 Ibid., 46, 47.

150 Ibid., 47-48.

151 John Hick, “A Remonstrance in Concluding,” in Jesus in History and Myth, ed. R. Joseph Hoffmann and Gerald A. Larue (New York: Prometheus Books, 1986), 212.

152 Hick, John Hick: An Autobiography, 125. 
Here Hick included three major Christological issues that seemed to him quite doubtful: atonement, virgin birth, and resurrection. These were put in the list because their literal interpretation is in serious conflict with modern science and does not pass the test of reason. Hick's agnosticism on these issues was only a beginning step to opposing the central doctrine of incarnation. Hick went on further because as long as the doctrine of incarnation is retained, his pluralistic hypothesis would not be able to stand. For if Jesus was literally God, and Christianity was founded by this Jesus, it is necessary that everyone must be Christian in order to be saved. The doctrine of incarnation must have been one of the major obstacles that must be disregarded or at least must be reinterpreted in his then-developing pluralistic hypothesis.

Thus, finally in Hick’s edited volume The Myth of God Incarnate (1977) he had to conclude that Jesus was “a metaphorical son of God” rather than "a metaphysical God the Son" as Christians claimed. ${ }^{153}$ His conclusion was drawn from his liberal hermeneutics with respect to the four Gospels. According to the "consensus," Hick insists, that is common to at least the most of university scholars, "none of them was in fact written by an eye witness." ${ }^{154}$ The Synoptic Gospels, Hick argues, must have been written as late as A.D. 70 and A.D. 80, while the Gospel of John was written in the 90s or even later. He also claims that "Jesus himself did not teach that he was God incarnate, or God the Son” ${ }^{\prime 55}$ on the basis of the scholarly consensus. The Synoptic Gospels, he insists, never taught that Jesus taught his divinity, while John's Jesus claims that he is God

\footnotetext{
${ }^{153}$ Hick, ed., The Myth of God Incarnate, 176.

154 John Hick, What Does the Bible Really Say? http://www.johnhick.org.uk/articles13,html, 2005 (accessed February 5, 2008). ${ }^{155}$ Ibid.
} 
incarnate. On the basis of this information, Hick seems to make the distinction between "the Jesus of history," and "the Christ of faith" to solve the dilemma of being contradictory to each other. He argues that "the Jesus of history" mainly depicted in the Synoptic Gospels, in which Jesus never taught that he was God, was changed by the church’s theologizing Jesus’ life, which happened in the Gospel of John and in the history of the Christian church, making him God incarnate.

Therefore all the hard-to-believe events of the Gospels, Hick argues, required reinterpretation through the glasses of modern science. If accounts concerning Jesus in the four Gospels do not pass the tests of reason, Hick reinterprets them as myth. As a result, insists Hick, in the course of church history the Jesus of history was transformed into the Christ of faith; the metaphorical son of God became the metaphysical God the Son. Though it is not my main goal here to criticize his biblical hermeneutics, it must be addressed that his hermeneutics are very much biased. His selection of biblical scholars was not balanced, but one-sided. Most of them, if not all, were from the liberal circle who shared the same hermeneutical principle of testing the Bible by human reason alone.

\section{Mythological Understanding of the Bible}

Traditional Christians believe that the Bible is the special and supernatural revelation of God. To them the stories of the Bible such as creation, fall, virgin birth, resurrection, and numerous miracles, must be understood literally, thus historically. This literal and historical interpretation of the Bible was one of the traditional ways of looking at biblical texts, seeking “to discover the author’s intent by focusing on the author's words in their plain, most obvious sense.”156 The Reformers of the sixteenth century,

\footnotetext{
156 J. Julius Scott, “Literalism,” Evangelical Dictionary of Theology, ed. Walter
} A. Elwell (Grand Rapids, MI: Baker Academic, 2001), 694. 
rejecting the fourfold meaning ${ }^{157}$ of Medieval theologians, argued for the single sense. Luther insisted that this is "the very simplest, . . . the literal, ordinary, natural sense."158 Hick's mythological interpretation of the Bible, though not on every text, may have been similar to the allegorical interpretation. Though myth ${ }^{159}$ to Hick is not exactly the same as allegory, they share one thing in common: They are neither literal nor historical.

What does he mean by myth then? He describes myth as follows:

I mean by a myth a story that is not literally true but that has the power to evoke in its hearers a practical response to the myth's referent-a true myth being of course one that evokes an appropriate response. The truthfulness of a myth is thus a practical truthfulness, consisting in its capacity to orient us rightly in our lives. In so far as the heavenly Parent is an authentic manifestation of the Real, to think of the Real as an ideal parent is to think in a way that can orient us rightly to the Real, evoking in us a trust which can pervade our lives and free us to love our neighbor. $^{160}$

We cannot claim that all elements in the Bible must be interpreted literally, because, for instance, as Hick illustrates, God the father cannot be our father in a literal sense, but in an analogy. God is described by Scripture in many ways such as Creator, Father, King, Lord, Shepherd, Rock, Commander, and so on. These obviously must be seen figuratively rather than literally. However, Hick’s mythological interpretation sees

${ }^{157}$ Medieval interpreters could interpret every text in four different ways: literal, moral, allegorical, and anagogical.

158 Scott, “Literalism,” 694.

${ }^{159}$ Hick says that myth and metaphor are similar but they are not the same. He argues, “A myth is an expanded metaphor." While a metaphor is composed in a single sentence, a myth is a more complicated story based on a metaphor. Hick, A Christian Theology of Religions: The Rainbow of Faiths, 102.

160 Ibid., 51. 
almost all events as well as teachings in the Bible are not literal ${ }^{161}$ and therefore as not true. For example, Hick considered "the stories of the creation of the world in seven days, and of the fall of Adam and Eve and their expulsion from the Garden of Eden" as "wellknown religious myths," ${ }^{162}$ thus they must not be literally true. His distinction between literal truths and mythological truths ${ }^{163}$ of the Bible are his way of getting rid of being in conflict with science in his theological interpretation.

Furthermore, the story of Jesus being the Son of God (incarnation) and coming down from heaven to save sinners as a human baby is "not literally true," Hick argues, "because it cannot be given an acceptable literal meaning, but is on the other hand mythologically true in that it tends to evoke in us an appropriate attitude to the Divine, the Real, as the ultimate source of all salvific transformation.” 164 The mythological understanding of incarnation is not only one of many rejections of biblical teaching, but it is a rejection of everything in Christian theology because Christianity itself is founded on Jesus’ being God, or God the Son, or the Second Person of a divine Trinity. As it is the main thesis of Hick's edited book Myth of God Incarnate, if the incarnation of Jesus is not literally true, Christianity will lose the foundation on which it is built.

${ }^{161}$ On the basis of his distinction between literal and mythological truth, Hick insists, "mythological truth is practical or ... existential" rather than factual. Hick, An Interpretation of Religion: Human Responses to the Transcendent, 348.

162 John Hick, The Fifth Dimension: An Exploration of the Spiritual Realm (Oxford: Oneworld, 1999), 236.

163 Though he does not want to deny the truthfulness of claims made by Christianity through mythological interpretations, Hick cannot avoid being accused of opposing the teachings of Scripture. Unless one starts reading the Bible with the basic, simple, literal meaning, nothing will be left from it but some precepts.

${ }^{164}$ Hick, A Christian Theology of Religions: The Rainbow of Faiths, 101-102. 


\section{Summary and Conclusion}

John Hick's life journey as a theologian and philosopher of religions is a lifelong pilgrimage from an exclusivist to an inclusivist, and eventually to a pluralist who not only approves other religions as true and genuine responses to the Real, but as a result, denies the essence of Christianity by rejecting its fundamental doctrine of incarnation. Hick's theology of religions, as discussed above, was a result of his lifelong experience of multidimensional aspects throughout his life: religious, academic, and social. ${ }^{165}$ Though the biographical sketch of Hick is not exhaustive, the background of his theological pluralism has been adequately addressed in the present chapter.

In concluding, it is worth reiterating some aspects presented earlier in this chapter: that Hick’s personal experiences as a Christian, professor, and social activist led him to doubt some Christian doctrines and to open the door for pluralistic ideas; that his mythological interpretation of the Bible was his solution for conflicts with science; that this mythological interpretation of biblical accounts led him to reinterpret and then ultimately to reject the Christian doctrine of incarnation; that this whole process led him to the eventual rejection of the Bible and eventually changed his life direction to become “the leading spokesperson for an extremely pluralistic theology of religions.”166

\section{Life Experience}

The leading spokesperson of religious pluralism, John Hick, was born out of multidimensional aspects—religious experience as Christian, academic experience as a

${ }^{165}$ Hick’s pilgrimage was a multidimensional experience of religious, academic, and social life. He had a strong conversion experience into orthodox Christianity, and throughout his teaching career he had academic as well as social exposures to the religions of the world, which had tremendous influences on his thought.

${ }^{166}$ Kärkkäinen, An Introduction to the Theology of Religions, 282. 
professor of many universities, and social relations in different cities and universities—of a lifelong pilgrimage. There were, in his lifelong pilgrimage, two main factors that shaped his theological framework. First, being the foundation of the latter, was the scientific knowledge that had a big impact on his theological thinking, because his starting point in theology was the presupposition of liberal theology that there was no inherent contradiction between theology and science. All theological truths must pass the tests of reason. Second, it was his exposure to the religions of world that shaped his theological system. Hick was not merely a theoretician who did research in a study, but an activist who continuously had interactions with other thinkers and religious groups. Throughout his lifetime, he has been involved in numerous conferences, seminars, and committees for religious, academic, and social matters. Through these, he began to reach the realization that there are many pious religions seeking the common goal of liberation or salvation. Thus, he insists, Christianity is only one of many different yet equally valid religions or one of many "different perceptions and conceptions of, and correspondingly different responses to, the real or the ultimate.”167

\section{Mythological Interpretation of the Bible}

Since the doctrines of Christianity must pass the tests of human reason, and must have no conflict with science, Hick inevitably had to reinterpret biblical texts. When the teachings of the Bible are in conflict with scientific knowledge of today, Hick must treat them as myth.

${ }^{167}$ John Hick, "Religious Pluralism and Absolute Claims,” in Religious Pluralism, ed. Leroy S. Rouner (Notre Dame, IN: University of Notre Dame Press, 1984), 194. 
For example, the story of the sun standing still for twenty-four hours recorded in Josh 10:12-14 is regarded as untrue by the modern mind of science, so he could not see it as a literal and historical event. When this same principle of mythological interpretation is applied to the great teachings of Jesus' incarnation, it eventually leads people to the denial of Jesus' divinity. According to Hick’s mythological interpretation, Jesus is not God the Son but merely a human like us. As discussed earlier, the Christ of the church is a result of the Church's confession of faith. The Christ figure of Christianity, argues Hick, possibly is “a creation of the human religious imagination."168 Thus, to Hick, Jesus boils down to "someone whom we try to follow as our model." 169 The human Jesus of Nazareth was just as sinful, frail, and imperfect as other humans are. This rejection of Jesus' incarnation and thus divinity must lead Hick to the denial of biblical authority as well as Christianity itself, because Jesus Christ being our Savior God is the foundation of Christianity. Thus the way for religious pluralism is wide open.

\footnotetext{
${ }^{168}$ Hick, What Does the Bible Really Say? para. 8.

${ }^{169}$ Hick, Science and Religion. para. 5.
} 


\section{CHAPTER III}

\section{AN ANALYSIS OF HICK'S PLURALISTIC HYPOTHESIS}

\section{Introduction}

The biographical sketch of John Hick shows that Hick’s theology of world religions was not a result of his theological studies or reflections alone, but of his lifelong struggle with his own religious, academic, and social life experiences. While chapter 2 shows how Hick developed his theology of world religion throughout his lifetime, chapter 3 will investigate Hick’s pluralistic hypothesis per se at a deeper level. It is necessary to examine Hick’s pluralism before entering into the discussion of his eschatological model of world religion. In other words, Hick’s pluralistic hypothesis, particularly the theocentric model of world religion, is the basis of other parts of his system. Thus, it is necessary to discuss Hick’s pluralistic hypothesis in depth as a prerequisite in order to understand his eschatological model of world religion.

While the main purpose of this chapter is to focus on the overall picture of Hick's religious pluralism, the major elements of his religious pluralism will be included in this study. Apart from the introduction and the conclusion, there will be four sections describing some key concepts of Hick’s pluralistic hypothesis in this chapter. First, Hick’s self-described “Copernican Revolution” will be discussed as a general picture of his theocentrism, which became the foundation of his theoretical framework. Second, Hick's concept of "the Real," which is the basis of his pluralistic hypothesis, will be included in discussion. Hick’s interpretation of the real plays a key role in the further 
discussion of his pluralism. Third, Christology, Hick’s biggest obstacle for his pluralistic hypothesis, will be discussed. It is included because it shows how he views Christ, who is the foundation of Christianity and, according to the historic Christian faith, is the only way of salvation. Finally, soteriology, which is the common denominator of all religions and closely related with eschatology, will be discussed as an opening door for the eschatology in the following chapter.

\section{Hick’s “Copernican Revolution” and Subsequent Kantian Shift}

The theological foundation of Hick's religious pluralism is based upon his theocentric model of world religion. This theocentrism is Hick's answer to the problem of plurality of religions and their conflicting truth claims and salvation claims. ${ }^{1}$ It is clearly seen in his self-described “Copernican revolution.” Hick adopted the term “Copernican revolution" from astronomy, in which it "involved a shift from the dogma that the earth is the centre of the revolving universe to the realization that it is the sun that is at the centre, with all the planets, including our own earth, moving around it."2 Thus, the essence of Hick’s Copernican revolution in Christian theology “must involve an equally radical transformation of our conception of the universe of faiths and the place of our own religion within it,"3 and must involve "a shift from the dogma that Christianity is at the

${ }^{1}$ The background of the Copernican revolution in theology is that orthodox Christianity claims that there is no salvation outside the church, or outside Christianity. If this is true, Hick argues, those who are not Christian are not saved but damned or lost.

${ }^{2}$ Hick, God and the Universe of Faiths, 131. As Yandall Woodfin notes, "Explaining that the copernican revolution in astronomy occurred when men no longer considered the earth the center of the universe but developed a larger solar perspective, Hick calls for a copernican revolution in the study of world religions" (Woodfin Yandall, review of Death and Eternal Life, by John Hick, Southwestern Journal of Theology 20 [Spr. 1978]: 95).

${ }^{3}$ Hick, God Has Many Names, 36. 
centre to the realization that it is God who is at the centre, and that all the religions of mankind, including our own, serve and revolve around him." ${ }^{4}$ As a result, the concept of God takes the place of church or Christ in Christianity as the central doctrine upon which all other doctrines are built. This involves "a parallel abandonment of the Christianitycentred assumption through recognition that Christianity is one of several religious traditions." ${ }^{5}$ As D’Costa says, “the Copernican revolution marked a shift from ecclesiocentrism and Christocentrism to one of theocentrism." ${ }^{6}$

Therefore, as Philip Almond notes, “the revolutionary aspect” of Hick’s view sees that "other religions are not assessed in the light of a theology constructed independently of them (so-called Ptolemaic epi-cycle theologies), but rather are a part, and crucially so, of the act of doing theology in a global context."7 Hick, unlike Hans Küng who argued for a "theocentric view" and whose God is the God of the Bible, seems to view all specific ideas of God as "culturally determined" ${ }^{8}$ and thus as appearing in different cultures differently as Jahweh, Allah, Vishnu, Shiva, Brahman, Nirvana, Sunyata, Tao,

${ }^{4}$ Hick, God and the Universe of Faiths, 131.

${ }^{5}$ Colin Grant, "The Threat and Prospect in Religious Pluralism,” The Ecumenical Review 41, no. 1 (Jan. 1989): 57.

${ }^{6}$ Gavin D’Costa, “John Hick and Religious Pluralism," in Problems in the Philosophy of Religion: Critical Studies of the Work of John Hick, ed. Harold Hewitt (New York: St. Martin’s 1991), 4.

${ }^{7}$ Philip Almond, “John Hick’s Copernican Revolution,” Theology 86, no. 709 (Jan. 1983): 36.

${ }^{8}$ Duncan Forrester, "Professor Hick and the Universe of Faiths," Scottish Journal of Theology 29 (Feb. 1976): 69. 
and so on. ${ }^{9}$ Hick's Copernican revolution leads to the idea that all religions have access and are in contact with the Real, but that the differences between religions are the result of their historical, cultural, and geographical differences. The theocentric model of religion is the fundamental basis for Hick's religious pluralism, which has some direct implications. First, it has crucial implications for Christology, because Hick’s theocentrism inevitably clashes with the foundational doctrine of Christianity, the doctrine of incarnation. Second, Hick's concept of the Real is very close to the God of the Bible. Theism is assumed in his system no matter what terminology he uses for the Ultimate Reality. Finally, there are apparently conflicting truth claims of different religious traditions in his pluralistic hypothesis.

\section{Hick’s Early Theocentric Model of Religions}

The theocentric model ${ }^{10}$ of world religions is Hick's early pre-Kantian way of solving the inevitable problem and dilemma that he faced in truth claims ${ }^{11}$ and salvation

${ }^{9}$ Hick, An Interpretation of Religion: Human Responses to the Transcendent, 271, 278. Hick argues that the Real is perceived differently, depending on various cultures, as personal beings or impersonal absolutes.

${ }^{10}$ As will be noted in the following subsection, there is a Kantian shift in Hick's model of religions. This shift is a further development, which D'Costa calls "Realocentrism" in Hick's thought after his transition from Christocentrism to theocentrism, which Hick calls his Copernican revolution. However, Hick’s Realocentrism replacing theocentrism does not mark as radical a shift as happened in his Copernican revolution. Rather it marks a change of terminologies or broadening of the theistically colored Christian name of God to "the idea of an ultimate Reality" (John Hick, "Straightening the Record: Some Response to Critics," Modern Theology 6, no. 2 [Jan. 1991], 189). Therefore, in my dissertation, I consider Hick’s Realocentrism as a broadening or further development of theocentrism.

${ }^{11}$ Hick's basic thesis, as David Basinger notes, is not "that different religions make no conflicting truth claims ... rather, is that such differences are best seen as different ways of conceiving and experiencing” the same divine Reality (David Basinger, “Hick’s Religious Pluralism and 'Reformed Epistemology’: A Middle Ground,” in The 
claims among different religions. The biggest obstacle that Hick encountered in his thinking toward a pluralistic hypothesis from the Christian perspective was "a central Christian position that salvation is through Christ alone," 12 that is, "outside the church, or outside Christianity, there is no salvation.”13 Hick’s proposal of theocentrism was his reconciling answer to the exclusive attitude of Christianity toward other religions, and at the same time was a sign of the denial of the fundamental Christian doctrine of incarnation. Hick’s theological argument that the concept of God or the divine is a common denominator of world religion is foundational to his religious pluralism.

There are two factors that led Hick the theocentric view of world religion: (1) the theological and moral argument — the concept of God's “universal love”; ${ }^{14}$ (2) the phenomenological argument- the cultural relativity of religions. ${ }^{15}$ The first factor that led Hick to his theocentric model of world religion is his idea of God who is "the God of universal love.”16 Hick’s idea of God must have been borrowed from the Christian concept of God whose dominant attribute is love. The concept of God's universal love, Hick argues, is not compatible with the real world where there are numerous people,

Philosophical Challenge of Religious Diversity, ed. Philip L. Quinn and Kevin Meeker [New York: Oxford University Press, 2000], 162).

${ }^{12}$ Hick, God and the Universe of Faiths, 121.

13 Ibid.

14 Ibid., 122.

${ }^{15}$ See Hick, An Interpretation of Religion: Human Responses to the Transcendent, 2; idem, A Christian Theology of Religions: The Rainbow of Faiths, 8.

${ }^{16}$ Hick, God and the Universe of Faiths, 122. As McCready argues, "He prefers what he calls the Irenaean understanding in which evil was an original part of creation and where humans are victims of that evil, victims who will be liberated in the consummation of God's purpose. This understanding presumes a universal salvation. Behind this universal salvation Hick sees a God of love” (McCready, "The Disintegration of John Hick’s Christology,” 261). 
maybe the majority of human beings, who are "outside the historical influence of Jesus of Nazareth" ${ }^{17}$ and are damned or lost. He adds, "Thus the doctrine that there is no salvation outside historic Christianity would in effect deny the universal love and redeeming activity of God.”18 This concept of God's universal love was a dominant attribute of God which led Hick to the initial development toward pluralistic thinking. As expressed in his book, Evil and God of Love (1966), God's universal love was presupposed in Hick’s theological framework. Hick argues, if "God is the God of universal love” who wants to save all, he must save at least the large majority of the human race if not all rather than “only a small minority” as Christians claim. ${ }^{19}$ It is this moral contradiction, in part, that led Hick to theocentrism.

The second factor that led Hick to theocentrism was phenomenological in nature: the cultural relativity of religions. ${ }^{20}$ This view, as Eddy observed it, is founded in the phenomenon that “one’s membership within one of the world's religions is generally a factor of parentage and birth place.”21 For instance, Hick argues, “when someone, anyone, is born to Muslim parents in Egypt or Pakistan or Indonesia, that person is very likely to become a Muslim; when to Buddhist parents in Tibet or Sri Lanka or Japan, to become a Buddhist; when to Hindu parents in India, to become a Hindu; when to Christian parents 1971), 119.

${ }^{17}$ John Hick, Arguments for the Existence of God (New York: Herder and Herder, 18 Ibid.

${ }^{19}$ Hick, God and the Universe of Faiths, 122.

${ }^{20}$ In favor of Smith's theory of religion, as Eddy observes, Hick presents the world religions as "a dynamic continuum" rather than as "mutually exclusive entities" or "rival ideological communities” (Eddy, “John Hick’s Pluralist Philosophy of World Religions,” 137-138.).

${ }^{21}$ Ibid., 152. 
in Mexico or Poland or Italy to become a Catholic Christian; and so on.”22 The idea that religion is an accident of birth led Hick to theocentrism, because it poses a problem in the traditional Christian exclusivism that there is no salvation outside the church or Christianity. In other words, if one's religion is based on one's ethnic, cultural, or geographic background, it is not fair to say that anybody's religion is better than somebody else's because they are all relative. The only fair answer is, Hick would argue, that everybody has slightly different views of the same God from his or her different backgrounds. $^{23}$

\section{Hick’s Later Shift to a Kantian Model of Religions}

Under the influence of Kantian philosophy, Hick proposed his “own contribution ... to the epistemology of religion," 24 which became the main solution to the conflicting truth claims particularly in regard to the different views of the Ultimate

${ }^{22}$ Hick, A Christian Theology of Religions: The Rainbow of Faiths, 8. He even claimed that "it is a fact evident to ordinary people (even though not always taken into account by theologians) that in the great majority of cases-say 98 or 99 percent- the religion in which a person believes and to which he adheres depends upon where he was born” (Hick, God Has Many Names, 61).

${ }^{23}$ Hick says: "It suggests to us that the same divine reality has always been selfrevealingly active towards mankind, and that the differences of human response are related to different human circumstances. These circumstances - ethnic, geographical, climatic, economic, sociological, historical-have produced the existing differentiations of human culture, and within each main cultural region the response to the divine has taken its own characteristic forms" (Hick, God and the Universe of Faiths, 138). Hick uses the parable of the blind men and the elephant, believed to be told by Buddha. The fact that all had different views of the same elephant, by having limited and different experiences of it, leads Hick to consider that "many different accounts of the divine reality may be true.” Hick adds that "the different encounters with the divine” are due to "encounters from different historical and cultural standpoints with the same infinite divine reality" rather than to "different parts of the divine" (ibid., 141).

261.

${ }^{24}$ Hick, An Interpretation of Religion: Human Responses to the Transcendent, 
Reality. With an appeal to Kant's distinction between "phenomena” and “noumena,”25 or between a "Ding an sich and that thing as it appears to human consciousness," ${ }^{26}$ Hick, applying this insight to the awareness of the Real, distinguishes "between the noumenal Real, the Real an sich, and the Real as humanly perceived in different ways as range of divine phenomena.” ${ }^{27}$ Thus, as Eddy rightly observes, "Hick began to experiment with a variety of terms"28 for "God"29 such as "the Eternal One,"30 "the Divine, the Transcendent, the Ultimate, the Real”31 in search of a more religiously neutral term, before he finally settled on his favorite one, "the Real.”

${ }^{25}$ Immanuel Kant, Critique of Pure Reason (London: Dent \& Sons, 1959), 186. Kant argues, "when we designate certain objects as phenomena or sensuous existences, thus distinguishing our mode of intuiting them from their own nature as things in themselves, it is evident that by this very distinction we as it were place the latter, considered opposition to the former, or, on the other hand, we do so place other possible things, which are not objects of our senses, but are cogitated by the understanding alone, and call them intelligible existences (noumena)” (ibid.). 241.

${ }^{26}$ Hick, An Interpretation of Religion: Human Responses to the Transcendent,

${ }^{27}$ Hick, A Christian Theology of Religions: The Rainbow of Faiths, 29. Hick explains his Kantian proposal in a highly generalized manner, arguing that "perception is not a passive registering of what is there but is always an active process of selecting, grouping, relating, extrapolating, and endowing with meaning by means of our human concepts” (ibid.).

${ }^{28}$ Eddy, “John Hick’s Pluralist Philosophy of World Religions,” 173.

${ }^{29}$ In God and the Universe of Faiths, where Hick presented his original selfclaimed "Copernican revolution," he almost exclusively used the title "God" as he mentions in his index. Hick, God and the Universe of Faiths, 199.

${ }^{30}$ Hick, God Has Many Names, 41-59. Here Hick's favorite title for God was "the Eternal One."

${ }^{31}$ Hick, A Christian Theology of Religions: The Rainbow of Faiths, 23. 
This whole process of changing terminologies for this Ultimate Reality occurred over a period of time, ${ }^{32}$ from the 70 s to the late 80 s and onward, and particularly in his An Interpretation of Religion (1989). This, however, does not mean that Hick has changed his idea concerning "an ultimate Reality,” but rather shows his change in terminology to have "the more tradition-neutral term 'the Real,",33 which may include theistic and nontheistic, personal and impersonal Ultimate Reality. Thus, Hick's use of the pre-Kantian term God up to the 70s is replaced by his new Kantian terminology "the Real.” In so doing, Hick seems not to have relinquished the basic theistic structure of the Ultimate Reality, but he wants to remove the theistic color in his use of it, broadening his previous views on that Reality. ${ }^{34}$

Hick claims that the great world religions are "different human responses to the one divine Reality, embodying different perceptions which have been formed in different historical and cultural circumstances. ${ }^{\text {} 35}$ In other words, what the religions of the world perceive in regard to the Real are different only phenomenologically, but they are their different yet authentic responses to the noumenal Real, which is beyond human cognition. All human perceptions of the Real are in a sense approximations of the Real as it is in itself.

${ }^{32}$ Hick, A Christian Theology of Religions: The Rainbow of Faiths, 65.

${ }^{33}$ Hick, “Straightening the Record: Some Response to Critics,” 189.

${ }^{34}$ John Hick, Who or What Is God? And Other Investigations (London: SCM Press, 2008), 4. Hick claims that some views of his critics such as D'Costa and Gillis are "obsolete" in their criticisms because they do not recognize Hick's continuing intellectual development (Hick, "Straightening the Record: Some Response to Critics," 194).

${ }^{35}$ Hick, God Has Many Names, 19. Also see idem, A Christian Theology of Religions: The Rainbow of Faiths, ix, 177. 


\section{Implications for Christology}

When Hick began to apply his Kantian distinction between noumenon and phenomenon to the doctrine of God, as McCready observes, "he could relativize the person and work of Christ as he sought for a way to reject the salvific claims of Christianity without giving up his claim to be a Christian.” 36 The paradigm shift from a Christ-centered model to a God-centered model of the universe of faiths, as Hick argues, must involve “a reopening of the Christological question.” ${ }^{37}$ Hick insists, if Jesus was not literally God incarnate as the paradigm shift implies, "the idea of divine incarnation is to be understood metaphorically rather than literally, as an essentially poetic expression of the Christian’s devotion to his Lord.” ${ }^{38}$ In other words, as Paul Knitter observes, Hick’s main thrust to "a theocentric, non-normative Christology is his insistence that Christian belief in the incarnation and in the divinity of Jesus is mythic and therefore not only allows but demands reinterpretation." 39 If this doctrine of incarnation is to be treated as a myth $^{40}$ rather than a literal truth, Jesus is not literally God the Son and the Second Person of the Trinity. This means that Christianity is without its foundation, the person Jesus Christ, on whom the entire Christianity is founded. This approach has further

${ }^{36}$ McCready, “The Disintegration of John Hick’s Christology,” 258.

${ }^{37}$ Hick, God Has Many Names, 19.

38 Ibid. 132.

${ }^{39}$ Paul Knitter, “Theocentric Christology,” Theology Today 40, no. 2 (July 1983):

${ }^{40}$ Hick's definition of myth which is something literally true but "invites a particular attitude in its hearers” is slightly different from Bultmann's understanding of mythology as expressed in Kerygma and Myth: "the use of imagery to express the other world in terms of this world and the divine in terms of human life” (Hick, God and the Universe of Faiths, 166). 
implications on the view of Scripture, whether it is God's special revelation for human beings, and on Christian soteriology, that salvation is through Christ alone.

\section{Theism Assumed}

As noted above, Hick’s pre-Kantian theocentric model of world religion was formulated from the Christian idea of $\mathrm{God}^{41}$ whose primary attribute is agape love. Hick's pre-Kantian God as loving creator is “formed and informed by Christian scripture and tradition,” said Chester Gillis, because "other traditions (for example, Buddhism, Hinduism) do not conceive of the divine (the Real) as a loving creator., ${ }^{\text {,2 }}$ The concept of God as the ultimate reality that is universal in every religion, as Hick assumes, is the basis of Hick’s religious pluralism. This means that Hick’s system of thought must presuppose the existence of the divine reality who is perceived differently in various cultures, times, and geographical places. As Eddy observes, "absolutely nothing can be said or known about the divine in and of itself., ${ }^{, 43}$ Hick is sure of the presence of the divine Reality, who can be experienced phenomenologically. Affirming the divine Reality, Hick argues, "the noumenal Real is experienced and thought by different human mentalities, forming and formed by different religious traditions, as the range of gods and absolutes which the phenomenology of religion reports. And these divine personae and metaphysical impersonae, as I shall call them, are not illusory but are empirically, that is

${ }^{41}$ At the beginning stage of Hick's Copernican revolution, the central figure that is the center of the universe of faiths was "a covert Christian God," as D'Costa observes. See D’Costa, “John Hick and Religious Pluralism,” 5.

${ }^{42}$ Chester Gillis, A Question of Final Belief: John Hick's Pluralistic Theory of Salvation (New York: St. Martin's, 1989), 170. This concept of God as loving creator is not consistent with Hick's own theory of the Ultimate Reality as unknowable as we will see later in this chapter.

${ }^{43}$ Eddy, “John Hick’s Pluralist Philosophy of World Religions,” 171. 
experientially, real as authentic manifestations of the Real." ${ }^{44}$ In this sense Hick is a critical realist who assumes the actual existence of the divine Reality in his interpretation of religion, no matter how he tries to describe that Reality either as personal being or impersonal reality.

\section{Truth Claims}

According to Hick, one of the major difficulties that religious pluralism faces in the world religions and their theologies is the problem of truth claims. That Hick recognizes “the 'conflicting truth-claims' of the different religious traditions” ${ }^{45}$ is obvious in his pluralistic hypothesis. Within all religious traditions, there are unique theologies that deal with some fundamental theological issues ${ }^{46}$ such as God (the Real), humans, salvation or life after death, and so on. Among many different types of truthclaims, ${ }^{47}$ at the center are the truth-claims about God or the Real. One of the most obvious examples is God or the Real as personal in Judeo-Christian traditions and

\footnotetext{
${ }^{44}$ Hick, An Interpretation of Religion: Human Responses to the Transcendent,
} 242. As will be shown, it is a contradiction that the Real is experienced and thought by the human mind. The issue of experience of the Real by human mentality will be dealt with in the following section.

${ }^{45}$ Ibid., 362.

${ }^{46}$ Harold A. Netland put these issues into "three questions" as follows: (1) What is the nature of the religious ultimate?; (2) What is the nature of the human predicament?; (3) What is the nature of salvation/enlightenment/liberation? Harold A. Netland, Dissonant Vocies: Religious Pluralism and the Question of Truth (Grand Rapids, MI: Eerdmans, 1991), 36.

${ }^{47}$ Hick lists disagreements among different religions in three different categories: (1) conflicting historical truth-claims; (2) conflicting trans-historical truth-claims; (3) conflicting truth-claims about the ultimate questions. Hick, An Interpretation of Religion: Human Responses to the Transcendent, 363-376. 
impersonal in Buddhism, particularly Theravada Buddhism. ${ }^{48}$ It is hard to see not only different but conflicting claims as the result of looking at the same Real, because they are not only disagreeing with each other but stand in contradiction to each other. This is one of the main dilemmas that Hick's pluralistic hypothesis of world religion deals with.

Though admitting them as “the apparently rival conceptions of the Real,” Hick shows the genius of his pluralistic hypothesis by adopting the Kantian distinction between noumenon and phenomenon and further appealing to "the principle of complementarity: those whose religious practice is as prescribed by the theistic traditions experience it[the Real] as a personal reality, whilst those who act in relation to it in the ways prescribed by the non-theistic traditions experience it as a non-personal reality."49 Therefore, Hick applies his pluralistic hypothesis_- "the great world traditions constitute different conceptions and perceptions of, and responses to, the Real from within the different cultural ways of being human" of apparently conflicting truth-claims. As will be discussed in more detail later, all the descriptions of world religions’ Ultimate Reality are on the phenomenal level, that is, not literally true. As Brian Hebblethwaite observes, if "they refer beyond the phenomenal to

${ }^{48}$ According to Hick, the Real is thought of in both "personal and non-personal terms" on the basis of Eastern and Western traditions (Hick, Death and Eternal Life, 453). However, as William J. Wainwright notes, "it is difficult to find an eastern tradition which regards ultimate reality as both personal and non-personal. Some eastern traditions view ultimate reality as personal while others do not" (William J. Wainwright, review of Death and Eternal Life, by John Hick, Anglican Theological Review 63, no. 3 [July 1981]: 346). 374-375.

${ }^{49}$ Hick, An Interpretation of Religion: Human Responses to the Transcendent, ${ }^{50}$ Ibid., 376. 
the noumenal Real, they function mythologically."51 The mythological understanding of the truth-claims in turn makes Hick’s hypothesis “less optimistic about cognitive complementarity."52 In other words, the descriptions of the Real become more and more vague as Hick’s system develops.

Moreover, Hick’s claim that "the broad differences between . . . [religions'] different images of the Eternal One arise from the broad differences between human cultures” ${ }^{53}$ does not give any satisfactory answer to their mutually exclusive claims of the same Reality. If they are their own perceptions or responses of the same Reality, why are they so different from one another? How do we know that their own conceptions originated from the Real? More fundamentally, how do we know whether the Real exists at all? A more detailed account of the language of the Real will be discussed in the following section.

\section{Theology (Doctrine of the Real)}

As clearly noted above, Hick's model of world religion is centered upon the concept of the Real or the divine Being. Whatever it is called, this divine Reality is the central focus of Hick's theology of world religion. Though taking a lot of time to explore the meaning of this Reality, Hick has difficulties doing so due to its inaccessibility in direct ways. If this Ultimate Reality ${ }^{54}$ is a key to the understanding of Hick's model of

${ }^{51}$ Brian Hebblethwaite, “John Hick and the Question of Truth in Religion,” in God, Truth and Reality, ed. Arvind Sharma (New York: St. Martin’s, 1993), 129.

52 Ibid., 130.

${ }^{53}$ Hick, God Has Many Names, 86-87.

${ }^{54}$ According to Hick, this Being can be called "God," "the Divine," "the Transcendent," "the Ultimate," "the Supreme Principle," "the Eternal One," and "the 
world religion, it is necessary to clarify first of all what Hick means by the Real. Then I will discuss other related issues such as the distinction between noumenal and phenomenal, the possibility of the knowledge of God, and finally, the linkage between the noumenal Real and the phenomenal Real.

\section{The Concept of the Real}

The concept of the Real which is at the center of the universe of faiths in Hick's religious pluralism is a very difficult concept to define. Hick’s central figure in the universe of faiths was acquired from conceptions related to the Christian Deity whose generic name is known as God to English-speaking people. As a matter of fact, up to the point when Hick proposed the Copernican revolution in the early 1980s he exclusively limited his use of the title God to describe the Being. For instance, in his book God and the Universe of Faiths (1973), as the title suggests, Hick used the title God throughout the book. Hick's use of the title God is natural because he, though proposing the pluralistic theology of religion, still did so from a Christian perspective. ${ }^{55}$

Struggling to find the best title for that reality, Hick showed a wide range of the use of titles in his writings throughout time as he was developing his theory. He said, "We therefore have such options as the Transcendent, the Ultimate, Ultimate Reality, the Supreme Principle, the Divine, the One, the Eternal, the Eternal One, the Real." ${ }^{56}$ The reason why he was struggling to find the right word is that once he chose one title, the concept of the reality would be limited and confined in the terminology itself, which

Real.” Hick, An Interpretation of Religion: Human Responses to the Transcendent, 10; idem, A Christian Theology of Religions: The Rainbow of Faiths, ix.

${ }^{55}$ As noted earlier, Hick was a religious pluralist in Christian perspective during the 1970s.

${ }^{56}$ Hick, An Interpretation of Religion: Human Responses to the Transcendent, 10. 
hardly contains that Reality. As can be observed in his writings, Hick did not want to limit himself to any one tradition by choosing the title of the Reality in favor of it. He must choose a title as neutral as possible that can satisfy all major world religions. In his struggle to find the most appropriate word, he chose some such as "the Transcendent, the Divine, and the Eternal One," among which he thinks the latter two would be "too theistically coloured."57 Finally, he was between two choices- “the Transcendent” and "the Real"-and chose the latter. This does not mean that Hick exclusively uses this term (the Real) to describe Ultimate Reality. ${ }^{58}$ Hick lists his reasons why he chose this title instead of others to describe Ultimate Reality as follows:

This term has the advantage that without being the exclusive property of any one tradition it is nevertheless familiar within all of them. In Christian terms it gives rise to no difficulty to identify God, the sole self-existent reality, as the Real. Within Islam the Real, al Haqq, is one of the names of Allah. Within the Hindu family of faiths it is natural to think of the ultimate reality, Brahman, as sat or satya, the Real. Within Mahayana Buddhism the Dharmakaya or sunyata is also spoken of as tattva, the Real. In Chinese religious thought the ultimate is zhen, the Real. 'The Real' is then, I suggest, as good a generic name as we have for that which is affirmed in the varying forms of transcendent religious belief. For it is used within the major theistic and non-theistic traditions and yet is neutral as between their very different ways of conceiving, experiencing and responding to that which they affirm in these diverse ways. ${ }^{59}$

Though Hick proposes using the words "the Real” to describe Ultimate Reality,

he does not use this term because he considers it adequate. According to him, "there is no adequate term” to describe Ultimate Reality. However, probably coming from a Christian

57 Ibid.

${ }^{58}$ He says, "I . . . for the sake of stylistic variety, sometimes use as synonyms 'the Ultimate Real' and 'ultimate Reality' or even simply 'the Ultimate' or 'Reality”” (ibid., 11).

${ }^{59}$ Ibid. In regard to the unknowable nature of God that is discussed by great theologians such as Augustine, Anselm, and Aquinas, see John K. Mozley, The Impassibility of God (Cambridge: University Press, 1926), 104-117. 
background, Hick argues, "it is customary in Christian language to think of God as that which is alone finally real, ${ }^{, 60}$ and this term does not offend other religious traditions.

Thus, I now have reached Hick's favorite term “the Real,” which is central to Hick's universe of faiths yet cannot be defined because the Real is beyond human cognitive ability. Hick's description of the Real is still confusing. As mentioned above, following Kantian insight Hick made a distinction between the Real as it is in itself and the Real as it is experienced in different religions. In his own words,

This distinction between the Real as it is in itself and as it is thought and experienced through our human religious concepts entails that we cannot apply to the Real an sich the characteristics encountered in its personae and impersonae. Thus it cannot be said to be one or many, person or thing, conscious or unconscious, purposive or non-purposive, substance or process, good or evil, loving or hating. None of the descriptive terms that apply within the realm of human experience can apply literally to the unexperienceable reality that underlies that realm. ${ }^{61}$

If nothing can be described about the Real itself, how can we know anything about it? Hick, however, does say something about the Real. He says, “All that we can say is that we postulate the Real an sich as the ultimate ground of the intentional objects of the different forms of religious thought-and-experience., ${ }^{, 62}$ Hick appeals to a "necessary postulate",63 argument, which is based on his epistemological rule that "the

${ }^{60}$ Hick, A Christian Theology of Religions: The Rainbow of Faiths, 18.

${ }^{61}$ Hick, An Interpretation of Religion: Human Responses to the Transcendent, 350. As Ninian Smart notes, Hick's system suggests that "there is a single something which lies in back of all the noumenal deities and so forth.... All these phenomenal deities and the like are so many representations of the one Real" (Ninian Smart, "A Contemplation of Absolutes," in God, Truth and Reality: Essays in Honour of John Hick, ed. Arvind Sharma [New York: St. Martin’s, 1993], 177).

${ }^{62}$ Hick, An Interpretation of Religion: Human Responses to the Transcendent, 350.

${ }^{63}$ Ibid., 249. 
phenomenal world is that same noumenal world as it appears to our human consciousness.” ${ }^{\prime 4}$ Though we have no direct access, Hick argues, we must postulate "such an unknown and unknowable Ding an sich," because without it "we should be left with a plurality of personae and impersonae each of which is claimed to be the Ultimate, but no one of which alone can be." 65 Thus, Hick's conception of the noumenal Real is the product of his postulate, based upon various phenomenal religious experiences. Hick's conception of the Real is not a direct knowledge of the Real itself, but a mere conjecture that is based on various religious experiences. We still have a question unanswered: Is real knowledge of the Real possible? Before inquiring about this question, I will discuss Hick's distinction between noumenon and phenomenon, the epistemological insights he adopted from Kant to deal with the dilemma of knowing the Real that is beyond our cognitive ability.

The Distinction between Noumenon and Phenomenon

As John C. Lyden observes, "Hick is not suggesting that all religions say the 'same thing,' or that there are no real differences among their concepts of the Real and the salvation it offers." ${ }^{, 6}$ Rather, what he is proposing is that every religion perceives the

${ }^{64}$ Ibid., 241. The fact that the Real appears is in a sheer contradiction to Hick's own statement that noumenon is unknowable.

${ }^{65}$ Ibid., 249. In agreement with Hick, Masao Abe insists that "both the Christian notion of God and the Buddhist notion of sunyata can be (or should be) understood equally to be absolute nothingness" (Masao Abe, "God and Absolute Nothingness," in God, Truth and Reality: Essays in Honour of John Hick, ed. Arvind Sharma [New York: St. Martin’s, 1993], 33).

${ }^{66}$ John C. Lyden, “Why Only ‘One’ Divine Reality?: A Critique of Religious 'Pluralism',” Dialogue \& Alliance 8, no. 1 (Spr./Sum. 1994): 61. 
Real differently in their own cultural, historical, and geographical backgrounds. ${ }^{67}$ Thus, "at the center of Hick's pluralistic hypothesis" ${ }^{68}$ is the distinction between noumenon and phenomenon, with which Hick tries to make ineffable noumenal Real available to human conceptuality phenomenologically. This distinction between noumenon and phenomenon is originally acquired from Kant's epistemological model in order to solve the apparent problem of contradictory notions of the Real. Unlike the realist who claims that knowledge is knowledge of the things, and the idealist who says that knowledge is knowledge of my own idea, Kant claims that "knowledge is transcendental.",69 It only knows the phenomenon (thing in me), not the noumenon (thing-in-itself). The noumenon (the thing-in-itself) is inaccessible, because it is not in me, "affected by my subjectivity." ${ }^{70}$ However, it must be noted that though Hick adopts basic Kantian epistemological insights, he is not strictly Kantian because he extends the noumenalphenomenal insight beyond sense experience to religious experience. ${ }^{71}$ Hick's adoption

${ }^{67}$ Hick says: "The same divine reality has always been self-revealingly active towards mankind, and . . . the differences of human response are related to different human circumstances. These circumstances_ethnic, geographical, climatic, economic, sociological, historical-have produced the existing differentiations of human culture, and within each main cultural region the response to the divine has taken its own characteristic forms” (Hick, “The New Map of the Universe of Faiths,” 282-283).

${ }^{68}$ Brad Seeman, "What If the Elephant Speaks? Kant’s Critique of Judgment and an Ubergang Problem in John Hick's Philosophy of Religious Pluralism,” International Journal for Philosophy of Religion 54, no. 3 (Dec. 2003): 162. 286.

69 Julian Marias, History of Philosophy (New York: Dover Publications, 1967),

70 Ibid.

${ }^{71}$ Hick, An Interpretation of Religion: Human Responses to the Transcendent, 244. He says, "Kant's own epistemology of religion was quite unrelated to his understanding of sense perception. But this fact does not bar others, inspired by his basic insights, from seeing religious and sense experience as continuous in kind, thereby 
of the Kantian distinction between noumenon and phenomenon not only made his pluralistic hypothesis work in the face of the dilemma of problems of conflicting conceptions, but also became his major tool for his perennial support for the pluralistic hypothesis.

Hick starts with one of Kant’s most fundamental “epistemological insights, namely that the mind actively interprets sensory information in terms of concepts.”72 Hick uses Kant's basic insight that “everything I know is made up of two elements: that which is given ${ }^{73}$ and that which I posit." ${ }^{74}$ The basic principle that Hick adopts from Kant’s epistemology had been already stated before by Thomas Aquinas: “Things known are in the knower according to the mode of the knower." ${ }^{75}$ This means the way we know things depends on our perception of them, which allows a major role of human subjectivity in epistemology. Hick applies this same principle "to argue that in relation to the divine the 'mode of the knower' differs within different religio-cultural systems so that the Real is thought-and-experienced in a wide variety of ways." ${ }^{\text {76 }}$ If the world we experience is partly our own construction, Hick argues, we must differentiate "between the world an sich, unperceived by anyone, and the world as it appears to, that is as it is extending Kant's analysis of the one, in an appropriately adapted form, to the other” (ibid.).

72 Ibid., 240.

${ }^{73}$ Russell observed inconsistency in Kant's system: Kant regards "thing in itself" which is inaccessible "as cause of sensations," that is, "what is given.” Bertrand Russell, A History of Western Philosophy (New York: A Touchstone Book, 1972), 708.

${ }^{74}$ Marias, History of Philosophy, 289.

${ }^{75}$ Hick, An Interpretation of Religion: Human Responses to the Transcendent, 241.

${ }^{76}$ Ibid. 
perceived by, us."77 This dichotomy between noumenon and phenomenon plays a major role in Hick's thought. By taking this basic insight of Kant's epistemology and applying it to our religious experience as Kant never did, ${ }^{78}$ Hick arrives at his own "Kantian revolution” ${ }^{79}$ as D’Costa calls it—“a synthesis that forms the foundation for his response to the problem of conflicting conceptions.” ${ }^{80}$ Thus, according to Hick's system, as Eddy notes, "conflicting images of the divine are not merely understandable, but are even to be expected." ${ }^{81}$ This line of argument could solve the central problem of Hick's pluralistic hypothesis, namely the problem of conflicting views of the Real. In other words, by applying his own "Kantian revolution" (dichotomy between noumenon and phenomenon)

${ }^{77}$ Ibid. Though the world an sich is not knowable to human mind because it does not appear thus is not perceived by us, there is the world as it appears to us, which is not literally same as the world an sich.

${ }^{78}$ As Hick notices, Kant's own epistemology of religion is "unrelated to his understanding of sense perception." Yet Hick, applying Kant's basic insights while not being strictly Kantian, sees "religious and sense experience as continuous in kind" (ibid., 244).

${ }^{79}$ D’Costa, “John Hick and Religious Pluralism,” 4. Gavin D’Costa calls this neoKantian insight a "Kantian revolution" which eventually becomes Hick's most favorite argument for the problem of conflicting conceptions. However, this Kantian revolution is not Kantian anymore, because it departed from his original thought that the noumenal Real is unknowable. See also Hick, An Interpretation of Religion: Human Responses to the Transcendent, 243.

${ }^{80}$ Eddy, "Religious Pluralism and the Divine: Another Look at John Hick’s NeoKantian Proposal," 468. Though Hick adopted Kant's epistemological insight that we cannot have direct knowledge of God, he goes beyond Kant by applying it to the realm of religious experience.

${ }^{81}$ Ibid. Hick insists that the noumenal Real is perceived differently by various religious traditions "as the range of gods and absolutes. ... And these divine personae and metaphysical impersonae ... are not illusory but are empirically ... real as authentic manifestations of the Real" (Hick, An Interpretation of Religion: Human Responses to the Transcendent, 242). Unlike Hick's phenomena that are different to everyone, Kant's categories are "a priori" and "universal.” In this sense, Hick is not in agreement with Kant on the noumenal Real. See ibid., 243. 
Hick is able to catch two rabbits at a time: he can affirm the existence of the single noumenal Real while maintaining the radically different conceptions of it in various world religions.

Responding to what Alston calls the "level distinction" between "the one ultimate reality" and its “pictures," “images,” or "representations", 82 — between the ultimate divine Reality and the different human conceptions and perceptions of that Reality—Hick presents his pluralistic hypothesis through the Kantian system of thought as follows:

Instead of giving rival accounts of a common intended referent, the religious belief-systems each give an account of a different referent, namely their own culturally influenced communal perception of the ultimately Real. On this view, we postulate the transcendent divine Reality which lies (as each of the great traditions at some point asserts) beyond our networks of human concepts; which is the ground of all existence and the source of all salvific power; which is conceptualized in a variety of ways in terms of the two basic religious categories of personal deity and non-personal absolute, and under each category in a variety of concrete forms as Adonai, the heavenly Father, Allah, Vishnu, etc., and as Brahman, the Dharmakaya, the Tao, etc. ${ }^{83}$

In this manner the Real is conceived differently in each tradition "through the complex lens of a human tradition, consisting of modes of thought, spiritual practices, sacred writings, theological and philosophical systems, great exemplars, and a web of historical contingencies of various kinds.” ${ }^{84}$ Thus the conception of the Real in each

${ }^{82}$ William P. Alston, "Religious Diversity and Perceptual Knowledge of God,” in The Philosophical Challenge of Religious Diversity, ed. Philip L. Quinn and Kevin Meeker (New York: Oxford University Press, 2000), 194.

83 John Hick, "Religious Pluralism and the Rationality of Religious Belief," Faith and Philosophy 10, no. 2 (1993): 248.

${ }^{84}$ Ibid. 
religion can be different, because "every human concept of God ... is a finite image, or mental picture, of the infinite divine reality that exceeds all human thought.”85

Though what produced Hick's system to deal with plurality of religious phenomena is Kant's epistemological insight, which is mainly for the realm of sensory epistemology, Hick made a shift in that he applied the Kantian insight to "the realm of religious epistemology,” as Eddy noted. ${ }^{86}$ Another divergence from Kant, Eddy insists, "involves the nature of Hick’s category-analogues." ${ }^{\text {" } 77}$ Whereas Kantian forms and categories are a priori, universal, necessary, and invariable, Hick's “categories of religious experience are not universal and invariable but are on the contrary culturerelative.”88 Being aware of the problems associated with Kantian epistemological interpretation, Hick does not want to enter into a Kantian dilemma of potential solipsism in the realm of religious matter. ${ }^{89}$ Like Kant who used the term "noumenon" in the negative sense- - we understand a thing so far as it is not an object of our sensuous intuition, thus making abstraction of our mode of intuiting it" ${ }^{\text {90 }}$ - Hick uses it in a negative way, as Eddy noted. Eddy writes, "he does not mean to make any positive

${ }^{85}$ Hick, God and the Universe of Faiths, 178. Thus, as Hick argues, "indeed all our concepts of God are 'images' of the infinite divine reality: Christ is the Christian's image of God” (ibid.).

${ }^{86}$ Eddy, “John Hick’s Pluralist Philosophy of World Religions,” 180.

${ }^{87}$ Ibid., 181.

${ }^{88}$ Hick, An Interpretation of Religion: Human Responses to the Transcendent, 243-244; Kant, Critique of Pure Reason, 26-27.

${ }^{89}$ Tony Bellotti, Does Kant's Theory of Knowledge Lead to Solipsism? http://www.philosophypathways.com/essays/bellotti3.html, 2006 (accessed March 21, 2008).

${ }^{90}$ Kant, Critique of Pure Reason, 186. 
claims regarding the unknowable divine noumenon.... Rather, he wants to refer to it only as a necessary postulate." ${ }^{91}$ None of the concrete descriptions about the Real in itself is proposed or affirmed by Hick because it is not within the realm of our conceptual frameworks. ${ }^{92}$ As D’Costa observes, "Hick is led into agnosticism”93 by his dichotomy between noumenon and phenomenon that he originally adopted to deal with the conflicting truth claims of world religions. Hick insists, "It cannot be said to be one or many, person or thing, substance or process, good or evil, purposive or non-purposive.”94 Nevertheless, Hick affirms that "the phenomenal world is that same noumenal world as it appears to our human consciousness" 95 while the unknowable noumenon exists regardless of our perceptions of it. Thus, though Hick admits that there is no access to the noumenal world, and claims that human religious experience is "not purely imaginary projection," ${ }^{96}$ he must posit "an element of human projection,"

${ }^{91}$ Eddy, “John Hick’s Pluralist Philosophy of World Religions,” 178.

${ }^{92}$ As Clarke noted, Hick's hypothesis implies that "none of the immediate objects of worship in the world's religions is real, while there is one, unknown Real-in-itself of which they are the humanly based images” (Peter B. Clarke and Peter Byrne, Religion Defined and Explained [New York: St. Martin's, 1993], 85).

${ }^{93}$ D’Costa, “John Hick and Religious Pluralism,” 6. D’Costa claims, “Hick is led into agnosticism when he presses the distinction between the Real in itself and its various phenomenal manifestations in relation to humankind. Agnosticism is the inevitable outcome of the trajectory of his flight from particularity, first from the particularity of the incarnation, then from the particularity of a theistic God, and then from the particularity of any religious claim, be it Christian or non-Christian" (Gavin D'Costa, "The New Missionary: John Hick and Religious Plurality," International Bulletin of Missionary Research 15, no. 2 [Apr. 1991]: 68). 246.

${ }^{94}$ Hick, An Interpretation of Religion: Human Responses to the Transcendent,

${ }^{95}$ Ibid., 241.

${ }^{96}$ Hick, A Christian Theology of Religions: The Rainbow of Faiths, 68; idem, Who or What Is God? And Other Investigations, 11. 
observe. Hick does not want to fall into the trap of either agnosticism that we know nothing about the noumenal world, or the conclusion that religions are the product of human delusion or imagination.

The Possibility of Knowledge of the Real

As John K. Roth notes, “Central to Hick’s analysis is the idea that no religious tradition describes 'the Ultimate as it is in itself." "98 As noted above the basic thesis of Hick in regard to the Real is that the Real is ineffable ${ }^{99}$ because it is "lying beyond the range of our human conceptual systems.”100 As observed by Kenneth T. Rose, this ineffability of the Real is "the central flaw of the hypothesis." ${ }^{101}$ Rose summed the essential problem succinctly as follows: “The central flaw of the hypothesis- the claim that the noumenal Real utterly transcends all human experience and knowledge-can never be overcome by any conceptual machinery. ... If the Real an sich is, as Hick contends, beyond speech, knowledge, and experience, then one has no choice but to remain silent about it.”102 If Hick is consistent in his system, he must admit that his attempt to explore the Real is useless because the Ultimate or Real is "utterly beyond our

${ }^{97}$ Clarke and Byrne, Religion Defined and Explained, 87.

98 John K. Roth, “Reply: Can John Hick Say What He Said?” in Concepts of the Ultimate, ed. Linda J. Tessier (New York: St. Martin’s, 1989), 160.

${ }^{99}$ Clarke and Byrne, Religion Defined and Explained, 94. As Clarke and Byrne note, "The Real in itself is literally indescribable. The only method of verification in religion relates to the practical effectiveness of the stories and myths we relate about the Real” (ibid.).

${ }^{100}$ Hick, A Christian Theology of Religions: The Rainbow of Faiths, 57.

${ }^{101}$ Kenneth T. Rose, "Knowing the Real: John Hick on the Cognitivity of Religions and Religious Pluralism” (Ph.D. diss., Harvard University, 1992), 12.

102 Ibid. 
comprehension." ${ }^{\prime 103}$ Thus, according to Hick's system, the Real remains utterly incomprehensible, as he responded to Joseph Prabhu: "Strictly speaking we do not know anything (in the strong sense of 'know') about the Real." ${ }^{104}$ Stephen T. Davis's suggestion is well taken: "All the religions are mistaken in what they say about the Ultimate. Hick simply rejects the way most religions understand themselves (to the extent that they make truth claims about the Ultimate)."105

However, Hick does not stop there with the ineffability of the Real itself by emphasizing "the utter transcendence of the Divine nature to any human thought" ${ }^{106}$ and developing his own epistemological principle based on Kantian epistemological insights. He lists several great church fathers to show "a strong tradition in Christianity of the ineffability of God.”107 Thus, Ward claims that "Hick's use of the noumenal/phenomenal distinction simply restates the classical Christian doctrine of the Divine ineffability.”108

${ }^{103}$ Hick, A Christian Theology of Religions: The Rainbow of Faiths, 58.

${ }^{104}$ In his response to Joseph Prabhu's "Response to John Hick" in regard to the Real, Hick affirmed that we know nothing about the Real, yet we can "postulate it in order to make sense from a religious point of view of the plurality of forms of religious experience-and-thought" (John Hick, "Response," in Concepts of the Ultimate, ed. Linda J. Tessier [New York: St. Martin’s, 1989], 172).

${ }^{105}$ Stephen T. Davis, "Comment on John Hick," in Concepts of the Ultimate, ed. Linda J. Tessier (New York: St. Martin’s, 1989), 164.

${ }^{106}$ Keith Ward, "Divine Ineffability," in God, Truth and Reality: Essays in Honour of John Hick, ed. Arvind Sharma (New York: St. Martin’s, 1993), 210.

${ }^{107}$ Ibid. Great names such as Gregory of Nyssa, Augustine, Aquinas, and St. John of the Cross are included. See Hick, An Interpretation of Religion: Human Responses to the Transcendent, 238.

${ }^{108}$ Ward, “Divine Ineffability,” 210. The traditional awareness of God's transcendence or infinity cannot be compared with the ultimate ineffability of the Real an sich in Hick's system. The former simply emphasizes God's nature of infinity or transcendence, not this notion of divine ineffability. Thus, as Eddy notes, "the classical notion of divine infinity entails nothing like the type of radical epistemological rift 
Adopting Kant's distinction between noumenon and phenomenon, Hick made a distinction between the Real an sich and the Real as phenomenally expressed in the different cultures and religions, which is the most basic thesis of Hick's pluralistic hypothesis.

The knowledge that is available to human beings is not the firsthand knowledge of the Real as it is in itself, but the secondhand one, if it is anything about the Real at all. Some questions are raised regarding the knowledge of the Real as it is in itself: If the Real as it is itself is known through the Real as thought and experienced, that is, only phenomenally, what is the kind of the knowledge of the Real as thought and experienced? How do we know that it is any knowledge of the Real itself?

Hick is positive on the question of the possibility of the knowledge of the Real. Hick argues that the only condition is, "we always perceive the transcendent through the lens of a particular religious culture." ${ }^{\prime 109}$ This means people have the knowledge of the Real within their own religion. However, Hick's claims, that the infinite Real which is beyond human cognitive ability is known through human thought and experience, are contrary to his fundamental thesis that the Real is utterly ineffable. Based on the distinction between "the Real in itself and the Real as humanly thought and experienced," Hick proposes "the hypothesis that the infinite Real, in itself beyond the scope of other than purely formal concepts, is differently conceived, experienced and responded to from

embodied in Hick's model” (Eddy, "Religious Pluralism and the Divine: Another Look at John Hick’s Neo-Kantian Proposal,” 470).

${ }^{109}$ Hick, An Interpretation of Religion: Human Responses to the Transcendent, 8. There is contradiction in Hick's thought about the noumenal Real, as Heim notes, "The epistemic validity of religious belief within varying traditions was taken by Hick to imply a unity or agreement of the religions in their core referent, which transcended the historical forms within which it was conceived" (S. Mark Heim, "The Pluralistic Hypothesis, Realism, and Post-Eschatology,” Religious Studies 28, no. 2 [Jan. 1992]: 214). 
within the different cultural ways of being human.”110 Thus, as S. Mark Heim notes, “Hick’s hypothesis implies there are some conditions in which it would be verified by an experience of the noumenal Real, i.e. experience of what cannot be experienced.»111

According to Hick's arguments, though the knowledge of the Real in itself, the noumenal Real, is not within the range of human consciousness, which exists independently of our perception of it, the knowledge of the Real as perceived, the phenomenal Real, is the same Real as it appears to us. Thus, Hick insists that the Real as it appears is "entirely real."112 This leads Hick to affirm that "the noumenal Real is experienced and thought by different human mentalities . . . and . . . by different religious traditions.” ${ }^{113}$ The distinction between the noumenal and phenomenal produces Hick’s conviction that the noumenal Real can be known through the phenomenal Real, because while the former remains beyond our human conceptuality, the latter reveals phenomenal representations of the former. The great religious traditions are "different ways of conceiving and experiencing the one ultimate divine Reality, and correspondingly 14.

${ }^{110}$ Hick, An Interpretation of Religion: Human Responses to the Transcendent,

${ }^{111}$ Heim, “The Pluralistic Hypothesis, Realism, and Post-Eschatology,” 213.

${ }^{112}$ Hick, An Interpretation of Religion: Human Responses to the Transcendent, 242. Hick's conviction that religious faith is “experiencing-as,"-developed from Wittgenstein's concept of 'seeing-as' but not merely seeing-as_-can be seen as a phenomenological interpretation of knowledge. He argues, "To recognize or identify is to be experiencing-as in terms of a concept; and our concepts are social products having their life within a particular linguistic environment” (Hick, God and the Universe of Faiths, 41-42). Thus, according to Hick, faith, along with every act of cognitionrecognition, presupposes an element of interpretation. See Gillis, A Question of Final Belief: John Hick's Pluralistic Theory of Salvation, 53; Hick, Faith and Knowledge, 151; idem, God and the Universe of Faiths, 37-52. 242.

${ }^{113}$ Hick, An Interpretation of Religion: Human Responses to the Transcendent, 
different ways of responding to that Reality."114 Even though the religions are responses to the same divine Reality, their conceptions of that same Reality are different to Hick. Understanding this “mixture of commonality and difference,” Hick adds, “in Christian terms it is the distinction between God in himself, in his eternal self-existent being, independently of creation, and God-for-us or God as revealed to us. In more universal language it is the distinction between the Real an sich and the Real as humanly experienced and thought.”115 This brings us to the basic dilemma of Hick’s pluralistic philosophy of religion, the cognitivity of the Real an sich. Unwilling to deny the cognitivity of religious language, Hick argues, “the core religious statements are true or false in a sense that is ultimately factual.”116

Assuming that everybody is exposed to the same Real as Hick suggestes, though it is natural to expect some variations due to the different historical, cultural, and geographical backgrounds, it is unnatural to expect them to be utterly contradictory to each other. As Eddy observes, the main dilemma of Hick’s pluralistic hypothesis is as follows: “Given Hick’s pluralistic model, one would prima facie expect human perceptions of the single divine Reality to be relatively similar, or at least not mutually exclusive, in nature. Phenomenologically, of course, this is anything but the case." ${ }^{117}$ One of the most obvious and problematic dilemmas is the problem of evidently contradictory notions of the divine between a personal Being and a non-personal reality. These two

114 John Hick, “The Philosophy of World Religions,” Scottish Journal of Theology 37, no. 2 (1984): 229.

115 Ibid.

${ }^{116}$ Hick, God and the Universe of Faiths, xvii.

${ }^{117}$ Eddy, "Religious Pluralism and the Divine: Another Look at John Hick's NeoKantian Proposal,” 467. 
responses are too different from each other to be from the single divine Reality. We are not sure whether they are responses to the same divine Reality. Accordingly, as Firestone observes, "Hick would not want to say ... that we must think that God as-He-appears is the same God as-He-is-in-himself.”118 Therefore, we can assume that the Real an sich represented in the work of Hick is knowable, but only in a phenomenological way at most, as he argues, "we speak mythologically about the noumenal Real by speaking literally or analogically about its phenomenal manifestations." 119 This brings us to a question of the circular relationship between the Real as it is in itself and the Real as experienced and thought.

The Linkage between the Noumenal Real and the Phenomenal Real

Though it is beyond the limit of human conceptuality, Hick wants to make certain formal statements about the noumenal Real without giving any concrete characteristics. For example, Hick, without giving any positive statement, offers “Anselm’s definition of God as that than which no greater can be conceived." ${ }^{120}$ If Hick cannot make any affirmative statement about the Real an sich, Hick's religious pluralism which is based upon his dichotomy between noumenon and phenomenon will not work. Thus, adopting Anselm’s definition of God, by “the Ultimate” or "the Real” Hick proposes to mean that "putative reality which transcends everything other than itself but is not transcended by

${ }^{118}$ Chris L. Firestone, “Kant and Religion: Conflict or Compromise?” Religious Studies 35, no. 2 (June 1999): 161. Firestone adds, "Hick rejects any theology which attempts to say that we are made in God's image and therefore have access (either potentially or actually) to a personal or direct relationship with God” (ibid.). 351.

${ }^{119}$ Hick, An Interpretation of Religion: Human Responses to the Transcendent, ${ }^{120}$ Ibid., 246. 
anything other than itself." ${ }^{\prime 21}$ The Real an sich in Hick’s thought is not the reality that human beings can directly experience, but some kind of putative reality that Hick proposed as "a necessary postulate of the pluralistic religious life of humanity."122 Regarding this necessary postulate, Hick says;

For within each tradition we regard real the object of our worship or contemplation. If, as I have already argued, it is also proper to regard as real the objects of worship or contemplation within the other traditions, we are led to postulate the Real an sich as the presupposition of the veridical character of this range of forms of religious experience. Without this postulate we should be left with a plurality of personae and impersonae each of which is claimed to be the Ultimate, but no one of which alone can be. ${ }^{123}$

This postulated noumenal Real, Hick insists, is the basis of "the encountered gods and experienced absolutes witnessed to by the religious traditions." ${ }^{124}$ Hick's arguments regarding the dichotomy between the postulated noumenal Real and "the encountered gods and experienced absolutes” still do not give a clear answer to the question whether they have a direct connection between them. Unless the linkage between the noumenal Real and the phenomenal Real in Hick's argument is seen, he could not make certain statements about the Real an sich because of its inaccessibility. It is hard to find the necessary linkage between this postulated noumenal Real and the conceptions of the Real in each world religion because we have no direct access to the noumenal Real in Hick's system. Without any knowledge of the Real an sich, there is no way for us to see the connection between them.

${ }^{121}$ John Hick, "The Real and Its Personae and Impersonae," in Concepts of the Ultimate, ed. Linda J. Tessier (New York: St. Martin’s, 1989), 143. 249.

${ }^{122}$ Hick, An Interpretation of Religion: Human Responses to the Transcendent,

${ }^{123}$ Ibid.

${ }^{124}$ Ibid., 246. 
Even if there is connection between them, it is hard to understand why Hick's range of phenomenological manifestations, that is, the multiple phenomenal appearances is so wide that we can hardly accept that they are manifestations of the same Real: They are not only different but some of them are contradictory to each other. ${ }^{125}$ Is there any relationship between the noumenal Real and the phenomenal Real at all? If there is any, what kind of relationship is there between them? Hick's answer is that there is no direct or literal relationship between them. As noted above, though Hick’s “noumenal world exists independently of our perception of it and the phenomenal world is that same world as it appears to our human consciousness,"126 the relationship between them is not clearly defined.

However, he insists, "this relationship between the ultimate noumenon and its multiple phenomenal appearances, or between the limitless transcendent reality and our many partial human images of it, makes possible mythological speech about the Real [emphasis added].”" 227 The best he could say about the relationship between them is that it is mythological rather than literal. This means the multiple phenomenal appearances are not literally true manifestations of the ultimate noumenon, but rather they are mythological truth which "tends to evoke an appropriate dispositional attitude to its subject matter.”128 Therefore, Hick claims, “Analogously, I want to say that the noumenal

${ }^{125}$ For example, conflicting truth claims regarding the Real are countless: theism with atheism, monotheism with polytheism, and most significantly the Real as personae and impersonae and so on. 241.

${ }^{126}$ Hick, An Interpretation of Religion: Human Responses to the Transcendent,

${ }^{127}$ Ibid., 247-248.

${ }^{128}$ Ibid., 248. 
Real is experienced and thought by different human mentalities, forming and formed by different religious traditions [emphasis added]." ${ }^{129}$ One thing is certain from his descriptions of the noumenal Real: They are not literal. Though Hick tries to avoid the problem of internal coherence between his claims about the Real as unknowable and several conceptions of it by using such words as "mythological speech," "analogously," and "phenomena" and so on, he has to make some positive statements about the Real which are literal, as he does in order to make his system of thought work. For instance, Hick says, the noumenal Real that is experienced and thought by different human minds and its manifestations "are not illusory but are empirically, that is experientially, real as authentic manifestations of the Real [emphasis added]." ${ }^{130}$ It seems that the Real manifests itself to us through something like a divine supernatural revelation of Christianity within each religion. This self-manifestation of the Real is even clearer in Hick's description of Henry H. Price's personal openness to the universal presence of the Real that he heard from Henry himself. Hick describes it as follows:

One Sunday morning, after a late breakfast, Henry found himself in an unusually tranquil and peaceful frame of mind. He felt moved to go into the drawing-room, where there was a writing-chair in the middle of the room, facing the empty fireplace. Then in a gentle and gradual way it began to dawn on him that there was someone else in the room, located fairly precisely about two yards away to his right front. There was no kind of sensory hallucination, either visual or auditory, nothing seen or heard. He was not in the least alarmed, and the experience itself was so absolving that he did not even feel any surprise at the time. It was just as if he had received a visit from someone he had never met

${ }^{129}$ Ibid., 242.

${ }^{130}$ Ibid. The descriptions of the Real that is experienced and thought by different religions are not only diverse but also contradictory according to Hick. Thus as Heim observes, Hick suggests that "regardless of the specific error or truth of their beliefs on things historical or trans-historical they are equally correct by virtue of being particular affirmations of the generic truth that there is a transcendent Real and that salvation/liberation comes by centring on it” (Heim, "The Pluralistic Hypothesis, Realism, and Post-Eschatology,” 215-216). 
before. They proceeded to have a conversation, though one conducted entirely by exchange of thoughts, about God's love for human beings, including himself. ${ }^{13}$

Hick claims that Henry went through a strong impression of the unknown visitor's presence at this moment. Hick says that Henry described this religious experience "as an experience of the sense of presence." ${ }^{132}$ Hick considers it to be "a moment of unusual openness to the universal presence of the Real, the Ultimate.”"133 Thus, it seems that Hick admits the idea of divine manifestation to the individual who is ready for it, which is exactly against his own understanding of the noumenal Real that is unknowable and beyond human conceptuality.

Though Hick does claim that the human religious experience is a "response to reality” as humans were originally structured, he cannot avoid people's accusation that his own suggestion is "imaginative projection"134 due to the inaccessibility of the noumenal Real. Hick's concept of the Real an sich is not based on the direct knowledge of the Real, but is the product of his own hypothesis on the basis of his own understanding of the world religions. Therefore, it must be noted that the linkage between the noumenal Real and the phenomenal Real is not clearly seen, as Hick assumes in his claims of religious pluralism. The conceptions of the Real an sich that Hick presents on the basis of his knowledge of the world religions seem to be at most mere postulate or imagination rather than real responses to the Real. There is no way to prove any direct connections between them. This failure to prove the necessary linkage between the

\footnotetext{
${ }^{131}$ Hick, John Hick: An Autobiography, 74.

${ }^{132}$ Ibid.

${ }^{133}$ Ibid., 75.

${ }^{134}$ Ibid., 153.
} 
noumenal Real and the phenomenal Real weakens Hick's theocentric model of the world religions.

\section{Christology}

Hick's main thrust in his pluralistic hypothesis, namely theocentrism, opened the way for not only a new but a radical interpretation of Christ the God incarnate. In his theocentric model of world religions, which is not in agreement with the orthodox doctrine of the divinity of Christ, "the incarnation continues to be the principal target of Hick’s doctrinal reinterpretation project." ${ }^{135}$ In other words, as Keith E. Eitel notes, "The net result of Hick’s model is a denial of the Incarnation.”136 The reinterpretation and denial of the incarnation, in turn, led him to reinterpret the Bible and understand its teachings as myth rather than historical and literal truth.

This section will include the following aspects of Hick’s Christology. First, though having briefly touched the issue earlier, I will look at how Hick’s Christology developed throughout time. In a sense, Hick’s Christological transformations over periods of time serve as one of the barometers to understanding his pluralism. Second, I will look at Hick’s own suggestion on Christology, namely “An Inspiration Christology,” which shows one of the obvious results of his theocentric model of world religions. Third, I will deal with Hick’s mythological understanding of biblical teachings including the doctrine of incarnation.

\section{From Christocentrism to Theocentrism}

${ }^{135}$ Eddy, “John Hick’s Pluralist Philosophy of World Religions,” 216.

${ }^{136}$ Keith E. Eitel, “'The Way’: Christ’s Uniqueness and Its Bearing on Modern Missions,” Criswell Theological Review 4, no. 2 (Spr. 1990): 283. 
Hick's own development of the theology of incarnation can well be summed up as a transformation “from Christocentrism to Theocentrism.” A major shift in Hick’s Christology occurred with his publication of “Christology at the Cross Roads” (1966). Here Hick assumed the central issue of Christology to be "the uniqueness of Christ," which he thought to "stand today at the cross roads."137 The central concern of Hick's Christology in regard to his uniqueness rests on the issue whether it is "a uniqueness of kind or of degree."138 Arguing for and against the Christology of the two writersNorman Pittenger in The Word Incarnate (1959), ${ }^{139}$ and Nels Ferre in Christ and the Christian (1958) ${ }^{140}$ — Hick found himself in favor of the degree Christology, yet argued against weaknesses of that model. ${ }^{141}$ The basic thesis of these two writers was, as Hick observed, that "God has been at work in essentially the same way in all men in all ages, but incomparably more fully and effectively at work in Jesus Christ than in anyone else.”142 He claimed, “the Degree Christology holds that Jesus Christ is unique in fact but not in principle.” ${ }^{143}$ The main point of Hick here, though not accepting their basic thesis

${ }^{137}$ Hick, "Christology at the Cross Roads,” 139.

138 Ibid., 140.

${ }^{139}$ Norman Pittenger, The Word Incarnate: A Study of the Doctrine of the Person of Christ (New York: Harper, 1959).

${ }^{140}$ Nels Fredrick S. Ferre, Christ and the Christian (New York: Harper, 1958).

${ }^{141}$ According to Eddy's observation, "the majority of the article is given to arguing against” the degree Christology. However, Hick's position is in agreement with the basic thesis of the degree Christology that the incarnation of Jesus is only one among many. See Paul R. Eddy, "John Hick and the Historical Jesus," in The Convergence of Theology, ed. Daniel Kendall and Stephen T. Davis (New York: Paulist Press, 2001), 306.

${ }^{142}$ Hick, “Christology at the Cross Roads,” 141.

143 Ibid., 144. 
that Christ is unique among all others, is that the incarnation is taking place all the time in different degrees everywhere.

Here Hick introduced his own Christological presentation, namely agape Christology—a neo-Chalcedonian Christology—as follows:

The neo-Chalcedonian claim is that the eternal divine agape towards mankind 'caused' Jesus' agape towards the men and women whom he met, in a sense analogous to that in which the radiating energy of the sun 'causes' the falling of its rays upon the earth's surface. That is to say, the sun radiating forth its light, and that light illuminating and warming the surface of the globe, form one continuous complex event; and likewise the divine agape exerting itself in relation to mankind, and operating on earth as the agape of Jesus, form one continuous event in virtue of which we can say that Jesus was God's attitude to mankind incarnate. ${ }^{144}$

Thus Hick made certain conclusions from this Christological hypothesis. First, Jesus had only one nature, which is "wholly and unqualifiedly human." 145 But this human nature was directed by God's agape. Second, Jesus had “one will, that of the man Jesus of Nazareth,” motivated by God's agape. Third, Jesus was conscious of God's agape "from the time of his baptism by John." ${ }^{146}$ However, Hick claims, "this does not mean that he was conscious of being God, or the Son of God, or the eternal Logos made flesh.” ${ }^{147}$ This article, as Gillis observes, “does set the groundwork for more radical proposals to follow," ${ }^{148}$ while not rejecting traditional Christology as a whole.

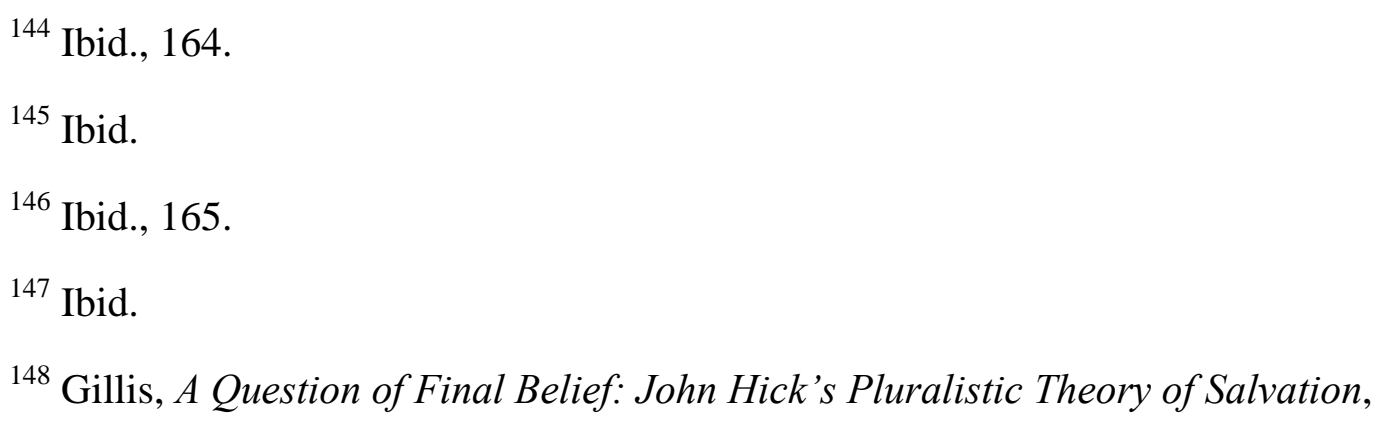
76. 
In his "The Reconstruction of Christian Belief for Today and Tomorrow," ${ }^{149}$ Hick shows his own starting point in his liberal and pluralistic understanding of Christianity by rejecting some fundamental Christian teachings (e.g., virgin birth, atonement, and resurrection). His concept of the Church and theology shows his radical approach in Christology. Hick insists, "So long as the person of Jesus of Nazareth is remembered, and gives rise to a continuing faith-response, the men and women in whom that faith-response occurs will be the Church, and the ways in which they conceptualize their faith will be Christian theologies.”" ${ }^{150}$ Thus theologies are human creations that are developed in history and are able to be modified and changed throughout time. Thus, Hick suggests, the development of world religions is to be viewed as "a dynamic continuum with major disturbances or creative religious movements” ${ }^{151}$ in the historical context of humanity. Hick argues, "it is not appropriate to speak of a religion as being true or false any more than it is to speak of a civilization as being true or false.” ${ }^{152}$ This marked Hick’s departure from traditional Christian theology, which reveals the fact that theology is not based on God's special revelation but based on human reason. ${ }^{153}$

149 John Hick, "The Reconstruction of Christian Belief for Today and Tomorrow: 1,” Theology 73, no. 603 (Aug. 1970): 349-345; idem, “The Reconstruction of Christian Belief for Today and Tomorrow: 2,” 399-405. 340.

${ }^{150}$ Hick, “The Reconstruction of Christian Belief for Today and Tomorrow: 1,” 77.

${ }^{151}$ Gillis, A Question of Final Belief: John Hick’s Pluralistic Theory of Salvation,

${ }^{152}$ Hick, “The Reconstruction of Christian Belief for Today and Tomorrow: 2,” 401.

153 This is basically a principle of liberal theology that Hick employed in his pluralistic hypothesis. 
In his God and the Universe of Faiths, Hick introduced his radical self-described “Copernican revolution” in theology, and made a paradigm shift from Christocentrism to theocentrism. As noted above, theocentrism inevitably clashes with the central Christian doctrine of incarnation, because Christianity stands on the doctrine of exclusive salvation through Christ. His article "Christ and Incarnation” is a reproduction of "Christology at the Cross Roads” (1966), which emphasizes that Jesus was exclusively human rather than divine. Thus, in his article “The Essence of Christianity," he argues that "the essence of Christianity is not in believing rightly but in acting rightly in relation to our fellows.” He contends, it is “not in thinking correctly Christ's two natures, as divine and human, but living as disciples who in his name feed the hungry." ${ }^{154}$ Finally, this volume suggests that the statement that Jesus is God incarnate is not a literal, but a poetic, symbolic, or mythological statement. ${ }^{155}$ Thus Hick’s thesis of incarnation as myth is introduced as an inevitable result of his theocentric model of the world religions.

With the publication of The Myth of God Incarnate (1977), Hick made a definitive statement that Jesus was “a metaphorical son of God” rather than "a metaphysical God the Son” as traditional Christianity holds, ${ }^{156}$ which is his reaffirmation of his earlier position. Jesus, who is not literally God incarnate, is compared with Buddha as another form of incarnation in Hick’s essay “Jesus and the World Religions.” Here Hick argues, "The human Gautama came to be thought of as the incarnation of a transcendent, pre-existent Buddha as the human Jesus came to be thought of as the incarnation of the pre-existent Logos or divine Son. . . . Gautama was the Dharma

\footnotetext{
${ }^{154}$ Hick, God and the Universe of Faiths, 109-110.

155 Ibid., 165-179.

${ }^{156}$ Hick, ed., The Myth of God Incarnate, 176.
} 
(Truth) made flesh, as Jesus was the Word made flesh.”157 According to Hick's argument, this same phenomenon can happen to any other prodigy of religion, even to any person who is in the presence of God or the Real.

Thus, Hick made a definitive move to pluralism in that Jesus being the Son of God, God the Son, is “a mythological idea” rather than a literal truth. He saw the incarnation of Jesus "as a mythological idea whose function is to evoke an appropriate response of faith in Jesus as Lord and Savior," ${ }^{158}$ as Cliford S. Hospital observed. This mythological understanding of incarnation, which is also the main thesis of his volume The Metaphor of God Incarnate, ${ }^{159}$ led him to open the door widely for the religious pluralism. As Eddy observes, though “Hick has substituted the term 'metaphor’ for 'myth"” in his later writings, his "incarnation as myth thesis” remains the same. ${ }^{160}$ Now I will focus on some aspects of Hick’s Christology that contributed to his development of the pluralistic hypothesis, namely “An Inspiration Christology” and "Mythological Understanding of Christ.”

${ }^{157}$ Ibid., 169.

${ }^{158}$ Clifford G. Hospital, “The Contribution of Keshub Chunder Sen toward a Global and Inductive Christology,” Journal of Ecumenical Studies 19, no. 1 (Win. 1982): 15.

159 John Hick, The Metaphor of God Incarnate: Christology in a Pluralistic Age (Louisville, TN: Westminster, 1993), 99-111. As the title of the book implies, Hick understands divine incarnation as metaphor rather than literal truth. This book shows Hick's reaffirmation of his earlier position on the issue: the conception that "Jesus as God incarnate is a metaphorical rather than a literal physical, psychological or metaphysical affirmation” (ibid., 109).

${ }^{160}$ Eddy, “John Hick and the Historical Jesus,” 310. 


\section{An Inspiration Christology}

As implied in his reinterpretation of Christian doctrines earlier, Hick’s “primary responsibility to contribute to the rethinking of absolutism” ${ }^{161}$ involves the traditional Christian doctrine of incarnation. “Since Christian 'absolutism' is chiefly fueled by the orthodox doctrine of the deity of Christ," says Eddy, "the incarnation continues to be the principal target of Hick’s doctrinal reinterpretation project.”162 Once the uniqueness of Jesus Christ as God incarnate is recognized as the Christian tradition claims, Hick’s whole project of religious pluralism is in jeopardy. Given this dogma that "Jesus Christ, the founder and focus of the religion, was God in human form or, more precisely, the Second Person of the divine Trinity living a human life,” Hick argues, Christians naturally see their religion as "the one and only true religion, founded by God in person and the locus of God’s unique saving act.”163 In order to deal with this fundamental dilemma of Christian uniqueness built into the doctrine of incarnation, Hick develops his reinterpretation project based on some contemporary writers such as Donald M. Baillie and Geoffrey Lampe.

Donald’s Baillie’s book God Was in Christ, ${ }^{164}$ Hick argues, shows how he remains orthodox while not retaining the traditional Christology. Hick sees him not criticizing the idea of incarnation but trying to make it intelligible to the modern mind by

${ }^{161}$ Hick, Disputed Questions in Theology and the Philosophy of Religion, viii.

162 Eddy, “John Hick’s Pluralist Philosophy of World Religions,” 216.

${ }^{163}$ Hick, "Religious Pluralism and Absolute Claims,” 196.

${ }^{164}$ Donald Baillie, God Was in Christ: An Essay on Incarnation and Atonement (New York: C. Scribner's Sons, 1948). See Scheid, "Scripture and Theology of the Religions: On the Theological Interpretation of Scared Scripture in Christian Attitudes toward World Religions,” 156. 
introducing a new incarnation called "the paradox of grace.”165 In Baillie’s words, Hick observes, the essence of the paradox "lies in the conviction which a Christian man possesses, that every good thing in him, every good thing he does, is somehow not wrought by himself but by God. This is a highly paradoxical conviction, for in ascribing all to God it does not abrogate human personality nor disclaim personal responsibility.”166 Thus, whatever man does is done through the grace of God dwelling in him. Baillie applies this principle to the case of Jesus’ incarnated life on earth lived not by his own will, but through God's dwelling in him. Through his new paradox of grace Christology, Hick observes, "Baillie discards the traditional Chalcedonian language of Jesus’ having two natures”167_ _divine and human natures. Baillie’s new theory of incarnation is taken by Hick as a good example of attempting to bring incarnation to the modern mind in intelligible terms.

The other good example that Hick chose to illustrate the new approach in the doctrine of Christology is called “a Christology of inspiration,” suggested by Geoffrey Lampe in his book God as Spirit. ${ }^{168}$ Lampe says that the Spirit of God "is to be understood, not as referring to a divine hypostasis distinct from God the Father and God the Son or Word, but as indicating God himself as active towards and in his human

165 Hick, “Religious Pluralism and Absolute Claims,” 206. Hick insists, the paradox is summed up in Paul's word, "It is not I, but the grace of God which is with me (1 Cor 15:10)” (ibid.).

${ }^{166}$ Baillie, God Was in Christ: An Essay on Incarnation and Atonement, quoted in Hick, "Religious Pluralism and Absolute Claims,” 206.

${ }^{167}$ Hick, “Religious Pluralism and Absolute Claims,” 207.

168 Geoffrey Lampe, God as Spirit: The Bampton Lectures (Oxford: Clarendon Press, 1976), quoted in Hick, Disputed Questions in Theology and the Philosophy of Religion, 53. 
creation.”169 By doing this, Hick understands that Lampe does not accept the traditional incarnation doctrine that the Logos is God the Son. On this view, God's Spirit has been active in the human life, enabling individuals to fulfill the will of God by their free responses. Therefore, it is not men or women who are doing the will of God, but the Spirit of God who is always active in human spirit, inspiring them to do it. And Hick adds, "This ... activity of God as Spirit means that God has always been incarnate in his human creatures, forming their spirits from within and revealing himself in and through them.” ${ }^{170}$ This is what happened in the life of Jesus on earth as he was inspired by the Spirit of God, who enabled him to fully respond to the will of God. Hick, by adopting this inspiration Christology, insists that he catches two rabbits at the same time: (1) a return to the original Christology held by the early church; (2) an advance to the more intelligible interpretation of incarnation that is acceptable to the modern mind. ${ }^{171}$

Therefore, according to Baillie and Lampe, Hick insists, “to speak of God's love becoming incarnate is to speak of men and women in whose lives God's inspiration, or grace, is effectively at work." ${ }^{172}$ Divine incarnation can occur and is occurring anywhere and anytime in any person or persons. Hick sees them still as holding "the centrality and

${ }^{169}$ Lampe, God as Spirit: The Bampton Lectures, quoted in Hick, Disputed Questions in Theology and the Philosophy of Religion, 53.

${ }^{170}$ Hick, Disputed Questions in Theology and the Philosophy of Religion, 53.

${ }^{171}$ Ibid., 54. Hick also claims that "the earliest strand of language in the New Testament documents probably expressed an inspiration Christology, seeing Jesus as a great prophet filled with the divine Spirit" (John Hick, "The Non-Absoluteness of Christianity," in The Myth of Christian Uniqueness: Toward a Pluralistic Theology of Religions, ed. John Hick and Paul F. Knitter [Maryknoll, NY: Orbis Books, 2005], 31).

${ }^{172}$ Hick, "The Non-Absoluteness of Christianity,” 32. 
superiority of Christianity within God's providence” ${ }^{173}$ because they assumed Christ's uniqueness, not in the sense that he was unique in kind but in the sense that he was unique in his response to God. Thus, as Terrence Merrigan notes, "the appeal of Spirit Christology for pluralist theologians ... allows the 'domestication' of Jesus as one inspired religious leader among others.” ${ }^{174}$ The incarnation Christology identifies Jesus as a mere man inspired by God among many others. Jesus should not be different in kind but only in degree from other inspired religious leaders. ${ }^{175}$ Thus Hick claims that "incarnation then becomes a matter of degree: God is incarnate in all men in so far as they are Spirit-filled, or Christ-like, or truly saintly." ${ }^{, 176}$ This model implies, as Hick suggests, that there is possibility of "plural incarnations." ${ }^{177}$ Therefore, according to an inspiration Christology, Jesus of Nazareth is not literally God incarnate, God the Son, Son of God, Second Person of the Trinity living a human life, as traditional Christianity claims. Hick argues, “This type of inspiration or paradox-of-grace Christology” falls within the range of options open to the religious pluralists, and is also "compatible with

${ }^{173}$ Hick, Disputed Questions in Theology and the Philosophy of Religion, 54.

${ }^{174}$ Terrence Merrigan, "The Image of the Word," in Newman and the Word, ed. Terrence Merrigan and Ian T. Ker (Grand Rapids, MI: Eerdmans, 2000), 28.

${ }^{175}$ Hick's notion of quantitative identity between the agape of Jesus and the divine Agape, which leads to "a Degree Christology," can be compared with this inspiration Christology. In a sense, an inspiration Christology is a type of degree Christology. See Hick, God and the Universe of Faiths, 157.

${ }^{176}$ John Hick, "Letters to the Editors: Incarnation," Theology 80, no. 673 (Jan. 1977): 205. Many other incarnations are not only possible, but there are in fact many incarnations in different world religions.

${ }^{177}$ Hick, The Metaphor of God Incarnate, 89-98. 
the religious pluralism.”178 This means that every person can be one like Christ so far as he or she is filled with the Spirit.

\section{Mythological Understanding of Christ}

Hick’s pluralistic approach to religions in general and to Christology in particular inevitably led him to reinterpret one of the core doctrines of Christianity, namely incarnation. Hick does not want to reject the doctrine per se, but he presents it in a different way from the traditional Christian doctrine. The main thesis of Hick's incarnation doctrine, that the incarnation is not literal but mythological was well, introduced in his God and the Universe of Faiths (1973). ${ }^{179}$ Hick says that the incarnation of Jesus “cannot apply literally to Jesus. But as a poetic image — which is powerfully evocative even though it conveys no literal meaning-it expresses the religious significance of Jesus” ${ }^{180}$ as traditional Christianity holds.

As Eddy observes, Hick offers three main lines of argument for his thesis of incarnation as myth thesis or for his rejection of a literal incarnation. Eddy writes:

First, drawing upon contemporary New Testament and historical Jesus studies, Hick argues that "almost certainly Jesus himself did not teach that he was God incarnate. Second, Hick proposes that one can trace the genesis and development of the notion of the incarnation in the early church up through the fourth century, along with the purely human concerns that motivate it. Finally, Hick contends that the mythological nature of incarnational language is betrayed in the fact that every attempt to explain it on a philosophical level reveals it to be nothing short of logically incoherent (i.e., "a self-contradiction," on the same logical par as "the idea of a square circle”) and thus literally meaningless. ${ }^{181}$

\footnotetext{
${ }^{178}$ Hick, “The Non-Absoluteness of Christianity,” 32.

${ }^{179}$ Hick, God and the Universe of Faiths, 165-179.

${ }^{180}$ Ibid., 172.

${ }^{181}$ Eddy, “John Hick and the Historical Jesus,” 306-307.
} 
If myths are not literal and thus literally meaningless, what purpose do they serve for the believers of religions? Hick claims that "myths are not literally true, but they may nevertheless be mythologically true." ${ }^{, 182}$ In order to understand this, we need to look at his definition of myth. He defines a myth as "a story which is told but which is not literally true, or an idea or image which is applied to something or someone but which does not literally apply, but which invites a particular attitude in its hearers." ${ }^{\prime 83}$ For example, Hick, though not admitting the six-day creation story and the fall of Adam and Eve in the Garden of Eden as literally true stories, claims that they may communicate truth "that the world is a divine creation and that humans are very imperfect beings living in a very imperfect world." ${ }^{\prime 184}$ Whatever he tries to say about it, Hick's myth is neither literal nor historical truth.

Hick's mythological-incarnation thesis that he developed in the 1970s remains unaltered in his later Christological treatise on the current issue, The Metaphor of God Incarnate: Christology in a Pluralistic Age (1993). Hick states the primary purpose of the book as follows: "The main conclusion of the book, embodied in its title, is that the idea of divine incarnation in its standard Christian form, in which both genuine humanity and genuine deity are insisted upon, has never been given a satisfactory literal sense; but that

${ }^{182}$ Hick, “A Remonstrance in Concluding,” 214.

${ }^{183}$ Hick, God and the Universe of Faiths, 166-167. Frances Young agrees with Hick that Jesus as God incarnate is not literal, scientific, ontological language which is traditionally interpreted to be, but mythological, poetic, confessional language which shows Christian conviction. See Frances Young, "A Cloud of Witnesses," in The Myth of God Incarnate, ed. John Hick (London: SCM, 1977), quoted in Scheid, "Scripture and Theology of the Religions: On the Theological Interpretation of Scared Scripture in Christian Attitudes toward World Religions,” 161.

${ }^{184}$ Hick, The Fifth Dimension: An Exploration of the Spiritual Realm, 236. There is at least one positive element here in Hick's thinking that he recognizes the Creator of the world, who is the center of his pluralistic hypothesis. 
on the other hand it makes excellent metaphorical sense." ${ }^{185}$ Trying to define what he means by "metaphor" in distinction from the literal meaning, Hick claims, "metaphor is a form of non-literal or figurative speech. ... Thus metaphorical speech is a use of language in which speaker-meaning differs from dictionary-meaning." ${ }^{186}$ Hick’s thesis of incarnation as myth (or metaphor in this book) is expressed in the title of the book itself-The Metaphor of God Incarnate—implying that the incarnation of Jesus is understood as metaphor or myth rather than as historical truth.

As Eddy notes, here Hick has four basic arguments for why he is against the traditional Chalcedonian incarnational Christology. Eddy says:

First, neither the teaching nor the apparent experience of the historical Jesus serves to authorize the claim of a literal incarnation.... Second, in retrospect, one can trace the historical process by which Jesus came to be thought of as "God," and can fully explain it in terms of human motives, both religious and even political (e.g., the Council of Nicaea)... . Third, according to Hick no rendition of the traditional model of "fully God and fully human," taken literally, has ever been shown to be meaningful. ... . Fourth and finally, Hick continues to emphasize that "historically the traditional dogma has been used to justify great human evils." 187

As Eddy observes, though Hick prefers to use metaphor rather than myth in his recent Christological writings, particularly in The Metaphor of God Incarnate, "this terminological change does not seem to signal any substantive modification of Hick’s

\footnotetext{
${ }^{185}$ Hick, The Metaphor of God Incarnate, 12.

186 Ibid., 99.
}

${ }^{187}$ Eddy, “John Hick and the Historical Jesus,” 309. Hick keeps claiming, when he uses biblical data, that his hermeneutics is based on "the modest but significant area of consensus" among biblical scholars. Hick's consensus includes the following: (1) a distinction between the Jesus of history and the Jesus of the Bible; (2) Jesus as a firstcentury Jewish prophet; (3) Jesus' self-recognition not as God incarnate (ibid.). 
thesis.”"188 It seems that Hick, knowing that in ordinary language myth is something not true, ${ }^{189}$ prefers to use metaphor because it has a more positive connotation than myth. To Hick, who sees myth as “expanded metaphors," 190 myth and metaphor are not different from each other; rather they have one thing in common: they both are neither literal nor historical. Thus, the thesis of incarnation as myth or metaphor led Hick to deny the deity of Jesus.

\section{Soteriology}

No matter how good it is, a religion without some kind of salvation is meaningless. Ultimately “all religions are religions of salvation.” ${ }^{191}$ As Hick notes, though they use different terms and concepts of salvation, ${ }^{192}$ all religious faiths, particularly all “post-axial faiths are soteriologically oriented.”"193 S. Mark Heim is right when he says, "If moral development is our guide to whether a salvific transformation is

${ }^{188}$ Ibid., 310. It seems that Hick is "merely attempting to root his former notion of the incarnation as 'myth' in more recent discussions that have focused on the metaphorical nature of language in general, and religious language in particular” (ibid.).

${ }^{189}$ Hick, The Fifth Dimension: An Exploration of the Spiritual Realm, 234.

190 Ibid., 236.

${ }^{191}$ G. van der Leeuw, Religion in Essence and Manifestation (New York: Harper \& Row, 1963), quoted in Grant, “The Threat and Prospect in Religious Pluralism,” 57.

192 Hick, An Interpretation of Religion: Human Responses to the Transcendent, 33. Hick says: "Christianity speaks of redemption and eternal life; Judaism of the coming kingdom of God; Islam of judgment and paradise; Hinduism of moksa; Buddhism of enlightenment and nirvana” (ibid.).

${ }^{193}$ Ibid. Hick adopted the concept of the axial age discussed by Karl Jaspers. It indicates primarily the period approximately from 800 to 200 B.C. when most of the major world religions began to appear. 
taking place, then it is taking place in all these traditions.”194 All major world religions share three common elements that are soteriological in a sense that they all recognize human misery, human possibility, and the way for a limitlessly better quality of existence. Though they cannot all be called "salvation" as in Christianity, they somewhat share a common element of this limitlessly better existence from humanity's present miserable situation. Hick, knowing salvation as a confined connotation of Christianity, prefers to use several terms interchangeably such as salvation, liberation, and transformation. ${ }^{195}$ Hick's soteriology must be understood in the light of his doctrine of the Real, which is the starting point for his entire system. Knowing "the idea that each of the great world religions is a response to the ultimately real, and that each is a context of human salvation," 196 Hick describes salvation as "the transformation of human existence from self-centeredness to a new orientation centred in the divine Reality." ${ }^{197}$ In turn, Hick’s soteriology is intimately connected with his eschatological model, what he calls “pareschatology,” because as we will see later, a salvific transformation is not complete for most people in this life. It is a continued process throughout several lives after death for the majority of people. Thus Hick's soteriology is a connecting bridge between his theological model (the concept of God) and eschatological model, which is the focus of my study.

${ }^{194}$ Heim, “The Pluralistic Hypothesis, Realism, and Post-Eschatology,” 208.

${ }^{195}$ Hick, An Interpretation of Religion: Human Responses to the Transcendent, $36-55$.

${ }^{196}$ Hick, A Christian Theology of Religions: The Rainbow of Faiths, 41.

${ }^{197}$ Hick, The Metaphor of God Incarnate, 136. 
In this section, I will lay the groundwork for the further discussion about Hick's eschatological model in the following chapter. First, I will look at Hick's definition of salvation in the context of the historical development that he went through. Second, I will discuss the aspect of salvation as human transformation, which he would like to call the "soul making process.” This concept of "soul making” is crucial to Hick’s pareschatology because it gives a rationale for his eschatological model. Third, I will discuss the concept of universal salvation that Hick's system inevitably presents. This idea of universalism must be thought of as a puzzle piece with other elements of his soteriology. And, finally, I will briefly discuss the salvation claims of other religions compared with Christianity.

\section{Historical Sketch}

Hick's analysis of Christianity's three approaches to other world religionsexclusivism, inclusivism, and pluralism—is a historical development of Christianity's attitude toward others as well as its threefold approach toward them throughout history. This is also reflected in his personal theological journey.

As noted earlier, Hick was not a religious pluralist from the beginning in his theological journey, but rather he was an exclusivist in regard to salvation. In other words, he used to believe "that salvation is through Christ alone, and therefore that those who do not respond to God through Christ are not saved but ... damned or lost." ${ }^{198}$ This exclusivism in regard to salvation has been the position of traditional Christianity. For example, Hick argues, the Bible teaching that "there is salvation in no one else" (Acts 4:12; John 14:6), and the "traditional Catholic teaching Extra ecclesiam nulla salus (no

${ }^{198}$ Hick, God and the Universe of Faiths, 121. 
salvation outside the church)"199 have been a very dominant position of Christianity. This theological exclusivism also served as a theological reasoning behind the nineteenthcentury missionary expansion.

Second, this exclusive Christian approach in regard to salvation has been “outflanked by the work of such influential Catholic theologians as Karl Rahner,”200 which can be categorized as inclusivism. Rahner’s idea of “anonymous Christianswithin the invisible church even without knowing it, and thus within the sphere of salvation"201_is one of his major theological achievements regarding soteriololgy. The basic idea is that no matter what religious group you are in, as long as you are devout, you are saved within your religious faith. However, Hick notes, this kind of inclusivism "recognizes the spiritual values of other religions, and the occurrence of salvation within them, and yet at the same time implicitly affirms the final superiority of their own religion over all others.”202 Thus, inclusivism claims that salvation is basically Christian salvation. All are saved, inclusivism would argue, by Christ and his atonement regardless of their acknowledgment of it or not.

Finally, Hick along with other pluralists, not being satisfied with the level of the openness of inclusivism, argues for religious pluralism. Based upon his pluralistic hypothesis that all religions are responses to the same ultimate Real, Hick insists that they all "seek to be contexts of human transformation from natural self-centredness to a new centring in the Real, the Ultimate, as differently conceived and experienced within

\footnotetext{
${ }^{199}$ Hick, The Metaphor of God Incarnate, 147.

200 Ibid.

${ }^{201}$ Ibid.

202 Ibid., 148.
} 
them." 203 Hick’s theology of God is the foundation of his soteriology. Again Hick says, "if salvation is taking place, and taking place to much the same extent, within the religious systems presided over by . . . various deities and absolutes, this suggests that they are different manifestations to humanity of a yet more ultimate ground of all salvific transformation.”204 In short, Hick’s pluralism suggests that all religions are only different paths to humans' ultimate salvation. This implies that there will still be different forms of worship, ethics, and theologies which will distinguish the world religions.

\section{Salvation as Human Transformation}

There remain some questions such as when and how salvation is realized in human life. Hick disagrees with traditional Christian claims that the judgment awaits a person in the future at personal death or on an eschatological day of judgment, and argues for salvation as human transformation to a perfection which usually does not take place within this short human lifetime. Hick suggests a process of coming to perfection as a "vale of soul making,"205 which will require many lives for the majority of people. This means that the time and the manner of salvation are various depending on people’s circumstances. Some who are closer to the Real may have only this life before they are saved, while others may need more lives to be saved. Since all religions are different perceptions of the same Real, this transformation can occur in any religion. The manner of salvation that constitutes human transformation from self-centeredness to Realitycenteredness could be various.

${ }^{203}$ Hick, A Christian Theology of Religions: The Rainbow of Faiths, 106.

${ }^{204}$ Hick, The Metaphor of God Incarnate, 140.

205 John Hick, Evil and the God of Love (New York: Harper San Francisco, 1977), 259. 
As Gillis notes, "Hick's theory of a vale of soul making is a logical outgrowth of his Irenaean view of the creation of human kind. ${ }^{, 206}$ In his book Evil and the God of Love Hick presents two major approaches to theodicy which involves the issue of human transformation. The first is the Augustinian tradition which flourished in the West, and has been dominant in Christianity. According to this traditional view, human beings are created as perfect beings with God's own image in them. Through the fall, however, they lost the image of God and fell into the sinful state which is inherited by all their descendants.

The second is the Irenean theodicy, prominent in the East, which Hick adopts. According to this position, human beings are not created as perfect beings as the Augustinian view claims. Hick adopts Ireneaus's distinction between "the image and likeness" of God in Gen 1:26. Though human beings, Hick argues, are endowed with "the image of God" at creation, they do not yet have "the likeness of God" which would be acquired in time. In Hick’s own words, "he was created as an immature and imperfect creature who was to grow in grace through time from the imago dei, which is the capacity for God, to the finite similitudo or 'likeness' to God, which is the perfection of our nature in relation to him.”207 This means, it is the actual human transformation that constitutes salvation. Adopting this Irenaean two-stage creation of the human being, ${ }^{208}$ Hick suggests that salvation takes place in human beings as "transformation from natural selfcentredness to a new centring in the Real, the Ultimate, as differently conceived and

${ }^{206}$ Gillis, A Question of Final Belief: John Hick's Pluralistic Theory of Salvation, 113. See Berel Dov Lerner, "Interfering with Divinely Imposed Suffering," Religious Studies 36, no. 1 (Mar. 2000): 95.

${ }^{207}$ Hick, Death and Eternal Life, 252.

${ }^{208}$ Hick, Evil and the God of Love, 254-265. 
experienced.”209 This means, human openness to the Real has a key role in the process of salvific transformation along with God's original framing of us in a way that we are “inwardly structured towards him." 210

There are many theological implications in the Irenaean view of creation, as Gillis notes. To begin with, "this Irenaean conception of the creation/development of humankind admits of no historical fall." ${ }^{\text {,11 }}$ This implication of a nonliteral understanding of the fall in Gen 3, which is assumed in his acceptance of Irenaean theodicy, must have led Hick to the foundation of future mythological understanding of the Bible and its teachings. Second, “Irenaeus's thought suggests an account of evil that sees it as having a place within the creative process of the universe." ${ }^{\text {212 }}$ This means, evil is something necessary for the perfection of human beings, not something that should not have existed at all from the beginning. ${ }^{213}$ As a result, the reality of evil is underestimated and even misunderstood. Third, since the Irenaean view claims that the creature is as immature as a baby at the time of creation, "the creature is ... on the road to perfection." ${ }^{214}$ This road

${ }^{209}$ Hick, A Christian Theology of Religions: The Rainbow of Faiths, 106.

${ }^{210}$ Hick, Death and Eternal Life, 252; John Hick, "Freedom and the Irenaean Theodicy Again,” The Journal of Theological Studies 21 (Oct. 1970): 421. 114.

${ }^{211}$ Gillis, A Question of Final Belief: John Hick's Pluralistic Theory of Salvation,

212 Ibid.

${ }^{213}$ G. Stanley Kane, “The Failure of Soul-Making Theodicy,” International Journal for Philosophy of Religion 6 (Spr. 1975): 15. Kane said: "Hick . . . believes that the existence of evil is necessary in order for man to be set at an epistemic distance from God” (ibid.). 115.

${ }^{214}$ Gillis, A Question of Final Belief: John Hick's Pluralistic Theory of Salvation, 
toward perfection is a slow process which usually is not finished by the time of death. Thus, for the majority of people it will require many lives to reach perfection.

\section{Universal Salvation}

The next questions that may come to mind are "Who then will be saved?" "Are some or all going to be saved?” This is another major theological issue that Hick addresses in his presentation of soteriology. Hick has moved in the direction of the concept that everyone will be saved eventually, namely “universalism,” or “universal salvation., ${ }^{215}$ His idea of universal salvation is clearly implied in his two books, Evil and the God of Love and Death and Eternal Life.

As Gillis observes, "The concept of universal salvation is important to our study because it impacts directly upon soteriological claims.”216 Hick argues for "universal salvation" as an antithesis of the doctrine of eternal torment in hell, which he claims to be contradictory to the idea of God as love. He lists why he rejects the doctrine of eternal torment as follows:

The objections to the doctrine of eternal torment which once seemed so weak and now seem so strong are well known: for a conscious creature to undergo physical and mental torture through unending time (if this is indeed conceivable) is horrible and disturbing beyond words; and the thought of such torment being deliberately inflicted by divine decree is totally incompatible with the idea of God as infinite love; the absolute contrast of heaven and hell, entered immediately after death, does not correspond to the innumerable gradations of human good and evil; justice could never demand for finite human sins the infinite penalty of eternal pain; such unending torment could never serve any positive or reformative purpose precisely because it never ends; and it renders any coherent Christian

${ }^{215}$ Hick writes one whole chapter under the title, “Universal Salvation.” He uses the two terms interchangeably. See Hick, Death and Eternal Life, 242-261. 106.

${ }^{216}$ Gillis, A Question of Final Belief: John Hick's Pluralistic Theory of Salvation, 
theodicy impossible by giving the evils of sin and suffering an eternal lodgment within God's creation. ${ }^{217}$

Hick's concept of universal salvation is based upon his idea of God who is infinite love. Universalism is derived from a reaction against his own Calvinistic doctrine of predestination which claims that there is a hell where eternal torment is going on for those who are lost. ${ }^{218}$ To him, it must not be acceptable that there is a God who is infinitely good and powerful, yet will bear with eternal torment in hell for the lost. ${ }^{219}$

Hick's idea of universal salvation is also a very crucial concept that has a direct connection with Hick’s pareschatology, which not only covers the Christian concept of eschatology but includes ideas much more than that, that is, there will be not only one eschaton but many eschatons before the final destiny of a human being. Thus it is important to understand Hick’s concept of universal salvation in relationship with his eschatological model.

Acknowledging the antinomy between "the omnipotent divine love intending man's salvation” and "human freedom," Hick tries not to exclude either of these but to retain them both by showing some evidences from the New Testament and his own argument in regard to human freedom. First, Hick argues, though there are times of Jesus warning people that “if they did not repent they would reap eternal damnation," and other New Testament writers telling about eternal punishment, "this threat is not incompatible

${ }^{217}$ Hick, Death and Eternal Life, 200-201.

${ }^{218}$ As a minister of the Presbyterian Church, Hick had to stick to its basic teachings including "the doctrine of double predestination to heaven and hell." To them, hell is a place where all the souls that are lost will be in eternal torment. See Jean Calvin, "The Institutes of Christian Religion," ed. Tony Lane and Hilary Osborne (Grand Rapids, MI: Baker Book House, 1987), I.16.4; Hick, John Hick: An Autobiography, 78, 88, 125.

219 Thomas Talbott argues in favor of a universalism that can be labeled necessary universalism. See Thomas Talbott, “The Doctrine of Everlasting Punishment," Faith and Philosophy 7, no. 1 (Jan. 1990): 19-42. 
with universalism." 220 However, Hick adds, "it did not follow from the fact of this danger that you or I or anyone else is in fact never going to repent and be saved.”221 Thus, according to Hick's understanding, in the New Testament universalism is not ruled out.

Second, Hick goes on to discuss the problem of human freedom in relationship with universalism. He argues, if we are free creatures, "God cannot coerce us into saving faith.”222 The only possible answer to universalism so far is that the omnipotent God must overrule the will of man, which can be interpreted as coercion. However, Hick introduces the Augustinian thought that "God has so made us that the inherent gravitation of our being is towards him.”223 This means that the human being's nature is “inwardly structured towards him.”224 Hick argues that God does not have to coerce us to save us, for he has already created us in such a way that our nature brings us to him. Therefore, he does not have to set aside either of these two antinomies (loving God and human freedom) to argue for universal salvation.

\section{Soteriology and Ethics}

Assuming from his pluralistic hypothesis that "salvation is in fact taking place not only within the Christian but also within the other great traditions," ${ }^{225}$ Hick argues that all are being saved within and through their own religions. Accordingly Hick's pluralism

${ }^{220}$ Hick, Death and Eternal Life, 250.

${ }^{221}$ Ibid.

222 Ibid., 251.

223 Ibid.

224 Ibid., 252.

${ }^{225}$ Hick and Knitter, eds., The Myth of Christian Uniqueness: Toward a Pluralistic Theology of Religions, 22. 
involves not only theology (who God is) but also its soteriology (what theology does in regard to the human predicament). In this sense, theology's major concern rests on soteriology, whether it provides salvation to its seeker, because theology without soteriology is meaningless.

Hick’s definition of salvation as "the transformation of human existence from self-centredness to Reality-centredness” is the "neutral, universal essence of religion,”226 argues Grant. This definition of salvation by Hick is too general and not clear enough to allow one to grasp its meaning. This leads us to raise another question in regard to soteriology: What are the criteria for judging religions if not all are valid ways to salvation such as the cults, led by Jim Jones and David Koresh? Hick's answer to this question of criteria is summed up as follows:

Any judgment about them has to be based on a close examination of each particular movement, and all that one can say in general is that the same criterion must apply as in the case of the great world faiths: are they effective contexts of the salvific transformation of human beings from self-centredness to a new orientation centred in the Real as authentically known in a particular human way? And the criterion of authenticity here can only be their observable moral and spiritual fruits in human life. ${ }^{227}$

Thus the apparent danger of pluralism in regard to salvation is that if all religious traditions are made relative, we could have a hard time distinguishing good from bad, the spiritually wholesome and profound from the spiritually poor and moribund religion. For instance, no one supposes that all religious leaders, all religious teachings, are equally valid or equally in touch with the Real. There is a substantial difference between a Jim Jones and an apostle Paul. Thus, Hick’s basic criteria for genuine religion are

\footnotetext{
${ }^{226}$ Grant, “The Threat and Prospect in Religious Pluralism,” 61.

${ }^{227}$ Hick, A Christian Theology of Religions: The Rainbow of Faiths, 110-111.
} 
soteriological—more particularly, whether they "promote or hinder the salvific transformation."228

The greater dilemma arises when it comes to the issue of truth claims on salvation, because all religions have different views of salvation. Some view salvation as a celestial place while others view it as nothingness; some view it as blissfulness in this life (no after-life) while others view it as blissfulness in the afterlife. This also requires some identifiable criteria. Hick suggests that the criteria for making that judgment lie in the "spiritual and moral fruits" 229 found in the lives of believers. But it is difficult to decide whether these fruits reveal a genuine or counterfeit sign of transformation, which can be purely subjective. We have no objective criteria of how good is good enough, how high is high enough. Accordingly, it is almost impossible to distinguish between good and bad religions in Hick’s religious pluralism.

\section{Summary and Conclusions}

In this chapter, I have surveyed the major elements of Hick’s religious pluralism as a basis of my discussion of his eschatological model. Some may wonder why one whole chapter is allotted to the discussion of Hick’s religious pluralism in general. On the one hand, as they may argue, it is right that this dissertation's main focus is Hick's eschatological model rather than his whole system of pluralistic hypothesis. On the other hand, however, though this dissertation is mainly about Hick's eschatological model and whether it is consistent with its own system, its main purpose is the proper evaluation of 300.

${ }^{228}$ Hick, An Interpretation of Religion: Human Responses to the Transcendent,

${ }^{229}$ Ibid., 301. The moral values are not only different but sometimes contradictory to one another. 
his religious pluralism as a whole. Thus, I have discussed some crucial elements of Hick's pluralism to see whether his eschatology fits into his whole picture as a puzzle piece, which in turn would show the adequacy of his overall model of religious pluralism.

I have discussed Hick's pluralism in four major areas in this chapter as follows: (1) Hick’s self-described “Copernican Revolution; (2) Theology (Doctrine of God); (3) Christology; and (4) Soteriology. This chapter tries to show what Hick attempted to do with his system of pluralism, which makes it descriptive in nature with some critiques. As noted above, Hick's pluralism is centered upon his doctrine of the Real or God, which frames other elements of his system. Hick's Copernican revolution in Christian theology involves a radical shift from the traditional teaching that Christianity (Church) or Christ is at the center, to the interpretation that it is God who is at the center, and that all religions revolve around him. Therefore, it views all religions as having responded to the same Real, but with different perceptions of it due to their historical, cultural, and geographical diversities.

In the second section, I dealt with Hick's doctrine of God or the Real. Since Hick's model of the world religions is centered upon the concept of the Real, it is necessary to see what this Reality is. Hick’s Real, however, cannot be grasped or defined fully because it is beyond human cognitive ability. Then some may wonder how we know that there is the Real at all. If we have no access to the Real as it is in itself, we must be silent about it. But Hick appeals to the idea that "we postulate the Real an sich as the ultimate ground of the different forms of religious thought-and-experience." ${ }^{230}$ His appeal to a necessary postulate is based on his thought that "the phenomenal world is that

${ }^{230}$ Ibid., 350. 
same noumenal world as it appears to our human consciousness.”231 Knowing that there are many concepts of God that are even contradictory to each other at times, Hick adopts the Kantian distinction between noumenon and phenomenon to deal with the problem of phenomenal multiplicity of the Real. Though the Real itself, Hick argues, is outside the realm of human comprehension, the Real as experienced is available. Thus, Hick insists that "we always perceive the transcendent through the lens of a particular religious culture.”232 To him, the knowledge of the phenomenal Real is the same Real as it appears to us. Hick's identification of the phenomenal Real with the noumenal Real, however, is done not in a literal sense but in a mythological sense.

No doubt Hick’s theocentric model of world religion made him reinterpret it and finally led him to the denial of the central Christian doctrine of incarnation. The traditional Christian claim that Christ is the only way for salvation is incompatible with Hick’s pluralistic hypothesis. Hick’s agenda for the incarnation doctrine was a reinterpretation at first, which eventually led him to say that it is not the incarnation of kind but of degree, and thus is a metaphorical or mythological truth rather than a literal and historical truth. In short, this whole process led him to reject the traditional foundation of Christian theology that Christ is God incarnate, through whom we are all saved.

Theocentrism led Hick to accept that God is the center of all religions and thus all religions are salvific. Though world religions use different terms and concepts of salvation, they share a common element of limitlessly better existence than man's present
${ }^{231}$ Ibid., 241.
${ }^{232}$ Ibid., 8. 
state of predicament. Hick claims that all religions are "soteriologically oriented,"233 that is, all religions are religions of salvation and thus there are transformations from selfcenteredness to reality-centeredness observed in them. To Hick, because each of the great world religions is a response to the divine Real, "each is a context of human salvation.”234 Hick’s soteriology does not stop here, but goes on further. He argues for the universal-salvation concept that all will be saved eventually. This idea of universal salvation has a direct connection with Hick's pareschatology because the salvific transformation of all does not take place in this world for all. For the majority of people it takes many lives for this transformation to be completed. Knowing the possibility of overruling human freedom with God's great love, Hick argues that the God of love has created human beings in a way that they are "inwardly structured” towards him.

As D’Costa notes, throughout his life, Hick’s theological pilgrimage moved “from Christocentrism to theocentrism to a Realocentrism.”235 These three words summarize Hick's personal as well as theological journey. Having started as an orthodox Christian who strongly held traditional Christocentric Christianity, Hick made a major shift by advocating a “Copernican revolution” which led him to reconsider the traditional understanding of Christ as God incarnate, replacing Jesus first with God or later the Real. Having launched the journey to theocentrism through his Copernican revolution, Hick began to show his radical approach to Christian theology. Thus, he had to deny the very foundation of Christian theology — the doctrine of incarnation. At this stage, Hick, not wanting to accept the doctrine anymore nor wanting to reject it at the same time,

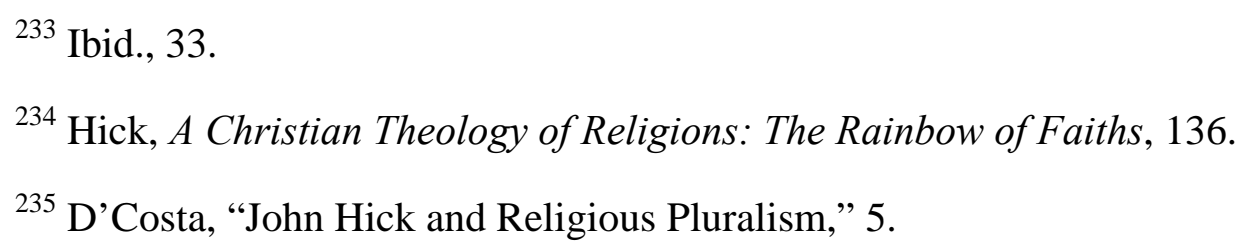


suggested a radical reinterpretation — a mythological interpretation of incarnation. Finally, even his theocentrism was replaced by a Realocentrism through his "Kantian revolution" in order to deal with multiple and conflicting phenomenal appearances of the Real. ${ }^{236}$ The pluralistic hypothesis was now well formulated with its basic components fitting into the whole picture. Hick's fullfledged pluralism was now redirected by his soteriological concern, which opened the way for his eschatological model, to be discussed in the next chapter.

${ }^{236}$ Hick’s Realocentrism replacing theocentrism does not mark a radical change in terms of reorientation but represents a broadening of a theistically colored Christian term God to "the idea of an ultimate Reality" (Hick, "Straightening the Record: Some Response to Critics,” 189). 


\section{CHAPTER IV}

\section{HICK'S ESCHATOLOGICAL MODEL-PARESCHATOLOGY}

\section{Introduction}

In the previous chapter I have dealt with the overall picture of Hick’s religious pluralism as a foundation for the discussion of his pareschatology. On the basis of my previous discussion regarding religious pluralism, particularly theocentrism and soteriology, Hick’s eschatological model may be summarized briefly as follows: Hick’s God or what he calls the Real is a loving one and thus will not let people suffer eternal torment in hell because of their shortcomings and mistakes of one short life. ${ }^{1}$ The traditional Christian “doctrine of hell is morally intolerable.”2 Hick’s appeal to this morally based argument is due to his understanding of the existence of evil in the presence of an all-good and all-powerful Ultimate Reality, which is the central problem of theodicy. ${ }^{3}$ Though salvific transformation is seldom accomplished in this life, ${ }^{4}$ by being made in the image of God in the beginning and later in the likeness of God as Irenaeus advocated through human openness to the Real, people gradually come to achieve a greater degree of human perfection. Finally all will experience the ultimate

${ }^{1}$ Hick, Death and Eternal Life, 201.

2 Ibid., 456.

${ }^{3}$ For more about theodicy, see Hick, Evil and the God of Love.

${ }^{4}$ Richard Hughes, "Bereavement and Pareschatology,” Encounter 43, no. 4 (Aut. 1982): 361. 
salvation through a continued soul-making process ${ }^{5}$ of being, which shows that Hick's theology of death is ultimately eschatological and teleological in a sense that everyone is moving towards the final perfection. In this whole process, Hick has applied the basic principle of evolutionism that human "species evolve" ${ }^{6}$ from a lower being to a higher one and to the final perfection. More particularly, Hick’s pareschatology is founded upon the evolutionary principle that concerns biological, psychological, and spiritual evolution of human beings. ${ }^{7}$ As LeRoy Moore notes, Hick believes that “earthly life and otherworldly reincarnation are preparations for the ultimate state beyond.”8 ${ }^{8}$ Thus, there will be not only one eschaton but many eschatons before the ultimate salvation of a human being, depending on how close he or she is to the Real. ${ }^{9}$

${ }^{5}$ Hick understands the soul-making process as a person's transformation of being that is observed when he or she is in a close relationship with the Real.

${ }^{6}$ David L. Hull, “Darwinism,” The Cambridge Dictionary of Philosophy, ed. Robert Audi (New York: Cambridge University Press, 2006), 204.

${ }^{7}$ Assuming the evolutionary principle, Hick says, "In this world man has emerged within the evolution of the forms of life as an unique complex being who is an animal, with instincts and drives geared to the struggle to survive; but at the same time a social and therefore ethical being, conscious of the other-regarding demands of his existence; and at the same time again a religious being, with innate tendency to interpret his experience in terms of the supernatural, and thus capable of responding to divine revelation” (John Hick, "Coherence and the God of Love Again," Journal of Theological Studies 24, no. 2 [Oct. 1973]: 523). See also John Hick, Biology and the Soul (Cambridge: The Cambridge University Press, 1972), 26.

${ }^{8}$ LeRoy Moore, review of Death and Eternal Life, by John Hick, Journal of the American Academy of Religion 46, no. 1 (Mar. 1978): 90. Moore also argues that "Hick postulates an anthropology of moral progression from body (earthly life) to mind (other worlds) to spirit (the ultimate)" (ibid.).

${ }^{9}$ Hick, Death and Eternal Life, 419. Hick says, "When we look at the best human lives, we can conceive of humanity reaching its perfection in them within one more life, and in others within a very few more. But when we look at the worst human lives we are more inclined to think in terms of tens or hundreds of lives. . . . At any rate it certainly seems that some will require a smaller and others a greater number of embodiments” (ibid.). 
This eschatological model of Hick’s represented as "pareschatology” — “the doctrine of the para-eschata, or next-to-last things" ${ }^{10}$ —is a unique conception, which "refers to the intermediate period between death and the ultimate state of being." ${ }^{11}$ As noted above, based upon the idea of universal salvation and Irenaean soteriology, Hick develops his own pareschatology, which is a combination of various eschatologies from East and West. ${ }^{12}$ As Hick notes, however, "it differs from the western tradition in postulating many lives instead of only one, and from the eastern tradition in postulating many spheres of incarnate existence instead of only one.”13 In other words, Hick postulates that there will be many lives in many different worlds other than this universe.

In order to discuss and evaluate Hick’s hypothesis of “many lives in many worlds," ${ }^{14}$ what he calls pareschatology, we need to understand his anthropology, and his ideas of death and afterlife. As a result of Hick’s discussion of eschatologies or pareschatologies from East and West, Hick presents pareschatology as a product of his religious pluralism which he thinks presents a possible solution for conflicting claims between them. Death and Eternal Life will be the main source of my discussion of Hick's pareschatology along with only a few authors. Since Hick’s pareschatology is largely

${ }^{10}$ Ibid., 22.

${ }^{11}$ Hughes, “Bereavement and Pareschatology,” 361.

${ }^{12}$ As David Cheetham notes, Hick's pareschatology is a "synthesis of eastern and western religious traditions about the afterlife" (David Cheetham, John Hick: A Critical Introduction and Reflection [Aldershot: Ashgate, 2003], 101).

${ }^{13}$ Hick, Death and Eternal Life, 456.

${ }^{14}$ Ibid., 414. This picture of many lives in many worlds before the final perfection or salvation of human beings is Hick's main thesis of pareschatology. It is during this period that human beings will go through the process of soul-making. 
ignored by the majority of scholars, there is only a small amount of secondary sources available.

\section{Anthropology}

Hick’s eschatological model focuses on "individual eschatology,” which concerns the immortality of the soul, rather than "general" or "collective eschatology" of the biblical tradition, which concerns a general resurrection of the saved at the end of history. ${ }^{15}$ There are questions that need to be answered in this section regarding Hick’s thought on anthropology before going into the main discussion on his pareschatology: What is man? Is a human being composed of two separable entities, physical and nonphysical parts? What is the concept of soul?

\section{What Is Humanity?}

How Hick views a human being — where he comes from in terms of his origin, how he is composed between mind and body, where he is going in the future-will be the basis of his understanding of a human's destinies after this life and more if there are any. Thus it is helpful to look at Hick's anthropology because his anthropology, I think, is the key to the understanding of his pareschatology.

As one assuming modern scientific method and its findings, Hick claims that from a purely human point of view a human being is a product of the shuffling of the enormous number of possible genetic codes with its "continuous interaction with its environment." ${ }^{16}$ He claims, "Behind each of us there lies an astronomical number of

\footnotetext{
${ }^{15}$ Wolfhart Pannenberg, "Constructive and Critical Functions of Christian Eschatology,” Harvard Theological Review 77, no. 2 (1984): 126.

${ }^{16}$ Hick, Death and Eternal Life, 35.
} 
other possible arrangements of the same genetic material." ${ }^{17}$ Nevertheless, his view of the emergence of human beings is not purely naturalistic because he attributes this process of random selection of genetic codes to the result of "the creative will of God."18 Thus Hick insists, "Our emergence out of the bewildering complexity of the genetic process is not in tension with the basic theological conception of man's utter contingency as a created being." ${ }^{19}$ While accepting modern scientific knowledge of biology or chemistry regarding human life, Hick wants to keep his religious conviction that there is a God who is creator of everything including human beings. Hick accepts that man was "created out of dust of the earth" as the Bible teaches. However, Hick's creator is not like the God of the Bible who created man and woman on the sixth day of the creation week, because he doesn't want to clash with "natural sciences of the origin of man." ${ }^{20}$ Thus, he says, "The details of the creative process, from dust to the immensely complex religious and valuing human animal, are for the relevant sciences to trace.”21 This position forced him to accept "the long, slow evolution of the forms of life, a process which has eventually produced man.”22 Hick’s acceptance of modern scientific knowledge led him to reinterpret or even reject some traditional biblical truths in the first few chapters of

17 John Hick, "Biology and the Soul," in Language, Metaphsics, and Death, ed. John Donnelly (New York: Fordham University Press, 1978), 151.

${ }^{18}$ Hick, Death and Eternal Life, 38.

${ }^{19}$ Ibid.

${ }^{20}$ Ibid., 46.

${ }^{21}$ Ibid., 47.

${ }^{22}$ Ibid., 46. Hick's conception that human lives are a product of a slow process of evolution is not compatible with his own thought that earthly human life is one of many possible lives in different worlds, which Hick's pareschatology suggests. This issue will be discussed more in detail later. 
Genesis. Particularly, the story of the fall in the Garden of Eden could not be a historical truth. According to Hick, the fall "did not take place at any point in time, from a paradisal condition which did not exist at any place." 23 The evolutionary process is done through the principle of the survival of fittest, which assumes that "death has always characterized life on this planet as have other evils such as earthquakes, storms, floods, droughts, and pests.” 24 This idea is against the traditional understanding of the stories in Gen 3. In order to get rid of his dilemma of being contradictory to the biblical truth, he adapted the Irenaean teaching regarding human origin, which distinguishes "between what he called the image of God and the likeness of God.” ${ }^{25}$ He suggested a two-stage creation of man as follows:

The imago dei is man's nature as a rational, personal and moral animal. Thus man in society, man the ethical being, man the creator of culture, exists in the image of God. It has taken many hundreds of millions of years of biological evolution to produce him, and yet even so he is only the raw material for the second stage of the creative process, which is the bringing of man, thus fashioned as person in the divine image, into the finite likeness of God. This latter state represents the fulfillment of the potentialities of our human nature, the completed humanization of man in a society of mutual love. Whereas the first stage of creation is an exercise of divine power, the second stage is of a different kind; for the creatures who have been brought into existence in God's image are endowed with a real though limited freedom, and their further growth into the finite divine 'likeness' has to take place through their own free responses within the world in which they find themselves. ${ }^{26}$

Thus according to Hick the creation of man is not completed but still going on. The process of creation is hardly to be completed in each person's life on this earth

${ }^{23}$ Ibid., 47.

${ }^{24}$ Keith R. Schmitt, Death and After-Life in the Theologies of Karl Barth and John Hick, Amsterdam Studies in Theology (Amsterdam: Rodopi, 1985), 119.

${ }^{25}$ Hick, Death and Eternal Life, 47.

${ }^{26}$ Ibid., 47-48. 
within seventy to eighty years. It is hard to think of the second stage of creation-the likeness of God—as finished in this life.

Hick's religious interpretation of human existence is teleological and eschatological. The meaning of the human being's life is to be understood in the perspective of what he is going to be in the future rather than the life on earth concluded at the time of death. That is why he said, "It is not what man has come from but what he is going to that is important." ${ }^{27}$ Thus Hick's man is in the process of making himself in the likeness of God in this life, or even life or lives after for most people. Hick suggests this final state of human being is to be something like "the central Hindu notion of the atman, the universal self which all the separate human consciousnesses unitedly are in the depth of their being." ${ }^{28}$ He claims that "the goal is a return to unity at a higher level, a movement from pre-individualized unity through separate egoity to a supra-individual unity." ${ }^{29}$ Hick insists that this state of atman is "the ideal state of human consciousness which waits to be realized through the negating of individual egoity." ${ }^{30}$ Though the conception of atman is identical to that of Brahman, Hick hesitates to equate this “eschatological humanity” (atman) with Brahman itself. ${ }^{31}$ If Hick’s final state of the human being is this egoless existence that can hardly be identified as someone from earth in heaven or paradise as Christian and other religious believers imagine, it is hard to think that this someone is said to be saved at all. If no self-identity is going to be recognized

${ }^{27}$ Hick, "Biology and the Soul," 159, 160.

${ }^{28}$ Hick, Death and Eternal Life, 51.

${ }^{29}$ Ibid., 53.

${ }^{30}$ Ibid., 52.

${ }^{31}$ Ibid. 
there and if one is in the state of "the fully realized collective consciousness of the atman," 32 it is hard to say that this state is ideal for all religious adherents to pursue.

\section{Dichotomous View of Mind and Body}

As Schmitt noted, Hick assumes that man is "composed of physical and nonphysical parts or realms, ${ }^{33}$ that is, body and mind. Unlike the concept of the physical aspect that can be seen and felt, weighed and measured, as Hick notes, the nonphysical aspect of human nature, which cannot be seen or felt, is conceived in a variety of terms such as "mind, soul, self, I, person, spirit, ego, consciousness, psyche, the subconscious, the unconscious, the id, the superego, mentality, transcendental unity of apperception, . . . jiva (or jivatman) and atman." ${ }^{34}$ Though Hick admits that it is impossible to put all these “terms into a single system,” he prefers to call this nonphysical part “a self,” more particularly “an embodied self,” 35 which is understood by Hick as something “identical” 36 with or "included" in the Christian concept of soul. ${ }^{37}$

It is crucial to see how Hick views the human being, whether he has two or more aspects or parts, mind and body, in order better to understand his eschatological model. 118.

32 Ibid., 53.

${ }^{33}$ Schmitt, Death and After-Life in the Theologies of Karl Barth and John Hick,

${ }^{34}$ Hick, Death and Eternal Life, 35.

${ }^{35}$ Ibid. Hick also discusses the self in relationship with soul, with which I will deal later. He said, "The Christian concept of soul undoubtedly includes this conscious self, which earns rewards and deserves penalties, which becomes or fails to become aware of God by faith, and which is to enjoy hereafter the blissful life of heaven or to suffer eternal loss of heaven” (ibid., 38).

${ }^{36}$ Ibid.

${ }^{37}$ Ibid., 38. 
Hick discusses this issue in the sixth chapter of Death and Eternal Life entitled "Mind and Body," ${ }^{38}$ which I will use as the main source. Presenting four basic options in regard to various views of the relation between body and mind, he starts his discussion with an assumption that these two are two separate parts. This aspect of a two-parts-theory of body and mind will be even clearer in Hick’s presentation of four main options of how body and mind are related.

The first option is monistic in nature, while all others are dualistic. It is known as the "mind/brain identity theory" which claims that "the two concepts refer to the same reality." 39 Mind/brain identity consists in "the electro-chemical function of the brain.”40 He insists that “while the names 'mind' and 'brain' have different meanings, they nevertheless in fact refer to the same object." ${ }^{41}$ According to this view, as Hick notes, "thoughts are not effects or by-products or epiphenomena of cerebral events, but thoughts and brain processes are the same things." ${ }^{42}$ Hick felt that this position went too far, because even though there is "ample evidence of mind/brain correlation" it is hard to say that mind and body are identical. ${ }^{43}$ Hick argues that though we can locate "a brain process in space, namely in a part of the cerebrum," it is impossible to "locate a mental

${ }^{38}$ Ibid., 112-128.

${ }^{39}$ Ibid., 112.

${ }^{40}$ John Hick, The New Frontier of Religion and Science: Religious Experience, Neuroscience and the Transcendent (New York: Palgrave MacMillan, 2006), 82.

${ }^{41}$ Hick, Death and Eternal Life, 113.

${ }^{42}$ Ibid.

${ }^{43}$ Ibid., 115. 
event in space.”44 Thus, the mind/brain identity theory is dismissed in Hick's idea of the relationship between body and mind.

The second option is called epiphenomenalism, which claims that "the mind is unilaterally dependent upon the body and has no independent efficacy.”45 Epiphenomenalism is "the view that whilst consciousness is different from the physical activity of the brain it is nevertheless generated by that activity and has no independent existence or causality." 46 In an analogy, Hick contends that "while electricity is flowing through a light bulb it produces light, but stop the current and there's no light. Likewise, electricity flowing through the brain produces consciousness, but stop the current and there is no consciousness." ${ }^{47}$ Unlike the mind/brain identity theory, it is a dualism that sees two different elements, the brain doing things with the mind reflecting what the brain does. The weakness of this position is that, as Hick notes, "the states of the brain determine the states of the mind, and never vice versa," ${ }^{48}$ which entails determinism. In other words, if the mind is a mere epiphenomenon, it is completely determined by the brain.

The third option is another dualistic view which claims that "although mind and body are entities of different kinds, and the mind influences the body as much as the body

${ }^{44}$ Ibid.

45 Ibid., 112.

${ }^{46}$ Ibid., 116.

${ }^{47}$ Hick, The New Frontier of Religion and Science: Religious Experience, Neuroscience and the Transcendent, 116.

${ }^{48}$ Hick, Death and Eternal Life, 116. 
influences the mind, yet the latter cannot function apart from the body."49 Through observations of mental work and various mental illnesses that are treated by drugs to the brain, Hick argues that the "mind and brain are independent but interacting realities, each of which can causally affect the other." ${ }^{50}$ In other words, mind and brain have mysterious reciprocal causality to each other. The interaction of body and mind "is unique and utterly mysterious." 51 Hick also observes the plasticity of the brain among the people born blind and those facing some physical traumas such as stroke. He says:

Using modern brain imaging techniques, it was discovered that people who had been born blind and used Braille throughout their lives had taken up the cortical areas that you or I would use for vision for processing touch. ... . [So] the brain had been modified so that parts people normally use for vision are now used for touch. Again, when stroke victims are able gradually to recover some of their lost abilities, this is done by constant effort, guided by physiotherapists, which forms new pathways in the brain to compensate for the damaged ones. ${ }^{52}$

Building upon the basic ideas of the third option, Hick proposes his own view on this issue as follows: "body and mind are entities of different kinds, mysteriously locked together in our present existence, but ... the mind may nevertheless be able to survive the death of the body"53 (emphasis added). One supporting example of a special function of

${ }^{49}$ Ibid., 112.

${ }^{50}$ Ibid., 120.

${ }^{51}$ Ibid.

${ }^{52}$ Hick, The New Frontier of Religion and Science: Religious Experience, Neuroscience and the Transcendent, 107.

${ }^{53}$ Hick, Death and Eternal Life, 112. Logically speaking these theories are two contradictory theories that cannot go together. However, Hick has an open view towards them both, because "both correct and incorrect trans-historical beliefs . . . can form part of a religious totality" (Hick, An Interpretation of Religion: Human Responses to the Transcendent, 370). Rather than insisting upon one theory against the other, at this stage Hick hesitates to choose between two views on afterlife, "the survival of the mind after the death of the body or . . . the reconstitution of the total phycho-physical being” (Hick, Biology and the Soul, 27). 
the mind and its possibility of survival after the death of the body is telepathy, ${ }^{54}$ which Hick believes to be a form of extrasensory perception. The existence of telepathy, Hick argues, which is mentally or psychologically rather than physically based and involves some kind of connection between minds, is a strong evidence of "the possibility of the mind's surviving the death of the body." 55 In this sense, Hick's dichotomous view of mind and body is clearly seen, ${ }^{56}$ though he develops it further in another context. ${ }^{57}$ Thus, the possibility of survival of the mind or nonphysical part after death is suggested by Hick's argument. Hick is now preparing a way to argue for what he calls "the traditional religious conception of the human being as an immortal soul," 58 which is in conflict with the teachings of Scripture. This leads us to the discussion of the concept of the soul.

${ }^{54}$ Hick says, "The most economic explanation of such an incident is that the one who experiences the hallucination has been affected telepathically by the mind of the one undergoing the crisis” (ibid., 122).

${ }^{55}$ Hick, Death and Eternal Life, 123.

${ }^{56}$ See ibid., 47. When Hick talks about creation of human beings, he tends to discuss the soul and the body separately. He says, "We have to say that the soul is a divine creation in the same sense as the body - namely through the instrumentality of the entire evolution of the universe and within this of the development of life on our planet" (ibid.).

${ }^{57}$ This view is modified more in chapter 22 of Death and Eternal Life, which presents a trichotomous view of the human being in either its Western version of "bodysoul-spirit" or its Eastern version of "body-mind-atman" (ibid., 450.).

${ }^{58}$ Ibid., 38. This does not mean that Hick argues for the immortality of the soul as most theists historically believed. As Frank B. Dilley notes, "the essence of the self (the mind or soul) can be separated from the body which it merely inhabits. Even those who historically believed in a resurrected body also usually believed that an immortal soul which once inhabited a body, persists between bodies, and has a body reattached to it again in the resurrection world" (Frank B. Dilley, "Resurrection and the 'Replica Objection',” Religious Studies 19, no. 4 [Dec. 1983]: 460). 


\section{Concept of Soul}

Being aware of the difficulty of defining the concept of soul, the nonphysical part of the human being, Hick says, “The term 'soul' has of course been used to refer to any of a whole family of notions, named by such terms as 'self,' 'higher self,' 'elusive self,' 'psyche,' ‘mind,' ‘ego,' ‘I,' ‘transcendental unity of apperception,’ ‘metaphysical subject,' etc.”59 Hick notes, “The Christian concept of soul undoubtedly includes [the] conscious self, which earns rewards and deserves penalties ... and which is to enjoy hereafter the blissful life of heaven or to suffer eternal loss of heaven.” ${ }^{60}$ In his discussion about the soul, Hick presents three traditional theories in regard to the origin of the soul. The first one is the doctrine of preexistence of the soul claimed by Origen. Roughly, as Hick says, it claims that "the soul existed in the heavenly realms before descending into this world, and that its present imprisonment in a material body is the result of a primeval fall from grace.”61 This thought is not derived from biblical teachings but from Greek philosophy.

The second one is traducianism, which claims that "the soul-substance which God breathed into Adam has been passed down through generation after generation of his descendants by continual division," ${ }^{62}$ as Hick notes. This view sees that the souls of people are all from the soul of the first man with slight modifications. This, Hick says,

${ }^{59}$ Hick, Death and Eternal Life, 313.

${ }^{60}$ Ibid., 38.

${ }^{61}$ Hick, "Biology and the Soul,” 39.

${ }^{62}$ Hick, Death and Eternal Life, 39. 
“can be seen as a mythological version of what actually happens as described by the science of genetics." 63

The third theory is creationism, as Hick says, which understands that "each soul is a new divine creation which God attaches to the growing foetus at some point between conception and birth.” ${ }^{64}$ Accordingly, God is said to create "a new soul and infuses it into each man." ${ }^{65}$ Creationism is supported and advocated by the Catholic Church. Hick is not satisfied with this theory. As he notes, if the soul is something that is created and infused into man, it is natural to assume that there are characteristics of the soul which are neither from inheritance nor from the environment. Unless the soul contributes to the personal essence of a human being in terms of human individuation besides heredity and environment, the soul would be a useless postulate. If there are characteristics derived from the soul, they must not purely “arise from the inherited genetic code, ${ }^{66}$ notes Hick. This means that if there is the divinely inserted soul in each person's life, we must assume that “there are innate personal qualities which have not been inherited from one's parents but which have been implanted by the Creator.”67

However, Hick claims that some aspects of innate aptitudes, such as intelligence, musical and artistic abilities, temperamental type and character structure, etc., are

${ }^{63}$ Ibid. Hick also notes that "traducianism also agreed well with the dominant Augustinian understanding of original sin as an inherited flaw” (ibid.).

${ }^{64}$ Ibid., 39-40.

65 Ibid., 39.

${ }^{66}$ Ibid., 40.

${ }^{67}$ Ibid., 41. 
inherited through the body that already contains genetic information. ${ }^{68}$ On top of this genetic basis of personality, Hick recognizes the presence of "the formation of moral character through the individual's interaction with environments." ${ }^{69}$ Yet he does suggest some third element— “the basic moral and spiritual dispositions" ${ }^{\text {"70 }}$ that he claims to inhere in the soul—that enables human beings to be free moral beings. That means if man's life is predetermined by both heredity and environment, he cannot be said to be totally free, as Hick's idea of man as a free being who is "placed at an epistemic distance from God"71 suggests. Thus Hick says: "The soul is the locus of our personal and moral freedom.... We should then identify the soul with certain fundamental dispositional characteristics—-presumably our basic moral and religious attitudes. ${ }^{, 72}$ Hick claims that insofar as one is different from another in morality and spirituality, "it will be impossible to disprove the claim that this difference is due to basic dispositions which were either implanted by God at conception or formed in previous lives."73 This however does not mean that Hick considers the soul as a created and infused substance, nor that "the term

\footnotetext{
${ }^{68}$ Ibid., 42.

${ }^{69}$ Ibid., 43.

${ }^{70}$ Ibid.
}

${ }^{71}$ Keith Ward, "Freedom and the Irenaean Theodicy," Journal of Theological Studies 20, no. 1 (Apr. 1969): 249. See also Hick, Biology and the Soul, 28; idem, Evil and the God of Love, 323; George Panthanmackel, "Problem of Evil: Hick's Sublimation of Plantinga," Journal of Dharma 23, no. 2 (Apr.-June 1998): 264. Hick argues that there is "epistemic distance" from God which presupposes man's independence from God. From the notion of epistemic distance he contends, as Panthanmackel notes, that "the fall of man was virtually inevitable” (Panthanmackel, "Problem of Evil: Hick’s Sublimation of Plantinga,” 264.).

\footnotetext{
${ }^{72}$ Hick, Death and Eternal Life, 42.

${ }^{73}$ Ibid., 43.
} 
soul can no longer have any proper use, but only that it should not be used as the name of a spiritual substance or entity.”74

This line of argument led him to consider it from a totally different perspective that Hick understands the word soul "as an indicator of value.” ${ }^{75}$ For instance, Hick suggests the use of "soul language or even to speaking of human beings as souls, or as having souls, in distinction perhaps from the lower animals."76 That means soul-language expresses the sacredness of human personality and inherent human rights. He proposes to see the word soul as a person and not some sort of mysterious divine entity hidden within him. This way of looking at the soul is somewhat parallel to that of the Scriptures, which view the soul not as some kind of substance that can be separated from the body and survive after death but as human consciousness or the human person as a holistic being. ${ }^{77}$ In this line of argument the soul is to be seen as an expression “equivalent to 'man,' or 'person,' or 'self,,”78 with which Hick would not agree, because he considers the

${ }^{74}$ Ibid., 45. This line of thought is incompatible with his dichotomy between mind (psycho) and body (physical), yet it may be consistent with the idea of man as a psychophysical unity because the soul is not something separable from body.

${ }^{75}$ Ibid. As Michael Perry notes, Hick believes that "'Soul' is the word we use to indicate the notion of value. The soul is not pre-existent, nor is it divinely injected into the soul-less embryo" (Michael Perry, review of Death and Eternal Life, by John Hick, Churchman 91, no. 3 [July 1977]: 267).

${ }^{76}$ Hick, Death and Eternal Life, 45.

${ }^{77}$ Hick notes that the body-soul dichotomy, first proposed as a philosophical doctrine by Greeks, came into Christianity with medieval modification and modern understanding through scientific findings. See John Hick, Philosophy of Religion, 4th ed. (Englewood Cliffs, NJ: Prentice Hall, 1990), 121.

78 “Ezekiel,” Seventh-day Adventist Bible Commentary, ed. Francis D. Nichol (Washington, DC: Review and Herald, 1978), 638. 
understanding of human being as soul to be mythological. ${ }^{79}$ Hick sees an individual as neither "a non-physical soul incomprehensibly interacting with a physical body," nor "as an eternal soul temporarily attached to a mortal body," but views him as a "psychophysical life." ${ }^{80}$ Though knowing that human beings have two parts, mind and body, and one may survive while the other is extinct, Hick perceives the human being as "an indissoluble psycho-physical unity" ${ }^{81}$ as we encounter it every day, which is in contradiction with his own suggestion of the possibility of the soul's survival after bodily death. Thus, Hick is leaning more towards the idea of man as a psycho-physical unity rather than the notion of soul or mind that can survive bodily death.

\section{Death}

Being fully aware of the inevitability and universality of death, Hick says, "Death comes impartially to everyone; there are no privileged or underprivileged in this matter; we are all in the end in the same boat." ${ }^{82}$ As the title of the book Death and Eternal life suggests, he presents an eschatological issue, a theology of death, as one of the agendas for his religious pluralism. It must have been crucial for Hick to deal with the issue of death, which is "a central concern of all the religions of the world," 83 to have a complete system of religious pluralism. For him "the question [is] whether the belief in an afterlife is or is not an essential part of the Christian faith," because he believes "upon this issue

${ }^{79}$ Hick, Death and Eternal Life, 39.

${ }^{80}$ Hick, Philosophy of Religion, 122.

${ }^{81}$ Hick, Death and Eternal Life, 278.

${ }^{82}$ Ibid., 87. The universality of death in human existence led him to construct a global theology of death in his book Death and Eternal Life.

${ }^{83}$ Ibid., 21. 
every other aspect of our theology of death necessarily hinges. ${ }^{\not 44}$ Hick seems to believe that a global theology (of death) is made possible by his pluralistic hypothesis.

\section{Death and Eternal Life}

It is worthy to discuss something about his work Death and Eternal Life that is the main source of this chapter. As Schmitt notes, Hick has "two basic and complementary goals" ${ }^{85}$ in his work Death and Eternal Life. The first goal is apologetic in nature. As Schmitt notes, "Hick argues that belief in life after death does not contradict and is not contradicted by the investigations of nontheological realms," ${ }^{86}$ claiming that this belief is universal in all religions. Hick did his own investigation not only in the realm of religions but also in the realm of other scientific disciplines. This open attitude of Hick is seen in his preface: "It seems to me that the claim of the religions that this life is part of a much larger existence that transcends our lifespan as animal organisms, whether through the continuation of individual consciousness or through participation in a greater transpersonal life, is very likely to be true. I shall argue that this is not ruled out by established scientific findings or by any agreed philosophical arguments. ${ }^{87}$ Hick’s openness to all data from every area of knowledge covers such disciplines as religious traditions, philosophies, psychology, anthropology, sociology, genetics, etc. His apologetic nature is clearly observed in every page of the volume.

${ }^{84}$ Hick, God and the Universe of Faiths, 184.

${ }^{85}$ Schmitt, Death and After-Life in the Theologies of Karl Barth and John Hick, 117.

${ }^{86}$ Ibid.

${ }^{87}$ Hick, Death and Eternal Life, 15. 
The second goal is to see whether a global approach, a global theology of death, is possible. Hick does not want to present "the possibility of a global religion,"88 which would require a uniformity in religious consciousness, but to seek a global theology (of death), which provides an interpretation that reconciles different beliefs, data, modes of religious experience. Hick distinguishes between two aspects of religion: First, its central affirmations concerning the nature of reality which are true or false; and second, the mythology which comes with the central affirmations but is ultimately not true or false. Regarding this Hick notes:

It is because affirmations about the nature of reality are true or false or, more probably, partly true and partly false, that the theologies of the different religions can be compared with one another, that agreements and disagreements can be registered, and that the possibility of syntheses and even of a comprehensive global theology cannot be excluded in advance. On the other hand, it is because religious myth and the practice of piety are phenomena of human culture that a global religion will never come about so long as there is - as let us hope there will always be-a wide variety of different styles of human existence. ${ }^{89}$

According to this approach, differences between religious traditions regarding death are not religiously significant because for Hick what is important is not theological understanding but the fact that "salvation/liberation takes place as well on one side or the other." ${ }^{90}$ As Heather Meacock notes, Hick claims that "faiths themselves ... may be salvific, despite the truth or falsity of their eschatological predictions." ${ }^{91}$ For Hick, thus, theology is of little importance, because as long as "both correct and incorrect trans-

${ }^{88}$ Ibid., 30.

${ }^{89}$ Ibid., 29.

${ }^{90}$ Heim, “The Pluralistic Hypothesis, Realism, and Post-Eschatology,” 211.

${ }^{91}$ Heather Meacock, An Anthropological Approach to Theology (New York: University Press of America, 2000), 183. 
historical beliefs ... can form part of a religious totality" ${ }^{32}$ that provides contact with the Real and salvific transformation, they are all valid. This line of argument is what Hick wants to achieve in his religious pluralism as well as in his global theology of death.

\section{A New Look on Death}

Hick's agenda inevitably led him to have a new look on death. Unlike the traditional Western view of death, which understands it as a consequence of sin, Hick presents a new approach, "what he calls a non-traditional view of death,"93 as Jay D. Robison notes. Hick argues that, according to traditional Christian theology, death is the result of the fall of humanity, "a punishment," "a disastrous consequence of man's turning away from his maker." ${ }^{\text {"T }}$ This Augustinian view sees death not as "an aspect of the divinely intended human situation, but is an evil, a state that ought never to have come about. ${ }^{95}$ According to this picture, as Hick notes, man, a finitely perfect creature, sinned against his Creator God, which brought death into the world. Death is seen as "a divinely inflicted punishment for sin." 96 Thus, man at the time of bodily death faces God's eternal judgment of either heaven or hell. As Hick notes, “God's purpose for the individual will be fulfilled in this life." ${ }^{97}$ 370.

${ }^{92}$ Hick, An Interpretation of Religion: Human Responses to the Transcendent,

${ }^{93}$ Jay D. Robison, Life after Death? Christian Interpretation of Personal Eschatology (New York: Peter Lang, 1998), 166.

${ }^{94}$ Hick, God and the Universe of Faiths, 190.

${ }^{95}$ Hick, Death and Eternal Life, 190.

${ }^{96}$ Ibid.

${ }^{97}$ Hick, God and the Universe of Faiths, 192. 
Not being satisfied with this traditional view, Hick presents an alternative view of death, which is based on the theology of Hellenistic Fathers, particularly Irenaeus's anthropology. ${ }^{98}$ According to this view "human beings were not created perfect but as immature creatures at the beginning of a long process of growth toward maturity,"99 which Hick accepts as his position on death. According to this line of reasoning, man did not fall from a perfect condition without sin into a disastrous condition of sin and guilt as Gen 3 describes. ${ }^{100}$ Rather, humanity as an immature creature is still in the process of being created in the likeness of God, as Irenaeus’s idea of a two-stage creation implies. This view contends that humanity is understood as taking a pilgrimage toward death, because "life is a soul- or person-making process" 101 while alive. The moment of death is,

${ }^{98}$ Ibid., 191. Hick traces this alternative to the strands of Eastern Christianity, the early Hellenistic Fathers, and German theologian Friedrich Schleiermacher. See Robison, Life after Death? Christian Interpretation of Personal Eschatology, 166.

${ }^{99}$ Robison, Life After Death? Christian Interpretation of Personal Eschatology, 166.

${ }^{100}$ Hick's interpretation of Irenaeus’s two-stage creation and rejection of the fall as an historical event is a result of overgeneralization of Irenaean theology. Hick may have drawn the idea of a two-stage creation from these statements that Irenaeus made: "But if the Spirit be wanting to the soul, he who is such is indeed of an animal nature, and being left carnal, shall be an imperfect being, possessing indeed the image [of God] in his formation (in plasmate), but not receiving the similitude through the Spirit; and thus is this being imperfect" (Irenaeus Against Herecies, 5.6.1). "Man, a created and organized being, is rendered after the image and likeness of the uncreated God, the Father planning everything well and giving His commands, the Son carrying these into execution and performing the work of creating, and the Spirit nourishing and increasing [what is made], but man making progress day by day, and ascending towards the perfect, that is, approximating to the uncreated One. For the Uncreated is perfect, that is, God. Now it was necessary that man should in the first instance be created; and having been created, should receive growth; and having received growth, should be strengthened; and having been strengthened, should abound; and having abounded, should recover [from the disease of sin]; and having recovered, should be glorified; and being glorified, should see his Lord” (ibid., 4.38.3).

${ }^{101}$ Meacock, An Anthropological Approach to Theology, 179. 
thus, not seen as “the moment when the individual's eternal destiny is irrevocably decided," ${ }^{102}$ as the traditional Christian theology understands.

From this new perspective, Hick argues that death has never been a disastrous or unnatural experience. In the process of soul-making, death is understood as "a necessary part”103 of man's experience of being made in the likeness of God. Thus, being aware of existentialist philosophers' understanding of death, which stresses how death sheds light on our lives, Hick suggests two meanings that man's death gives to his life. First, a person's death shows its meaning to others, how his life is seen in its totality. He says, "For only when a life has been rounded off by death are we able to see it in its totality and so to characterize it as a whole.” ${ }^{104}$ Second, the manner of a person’s “dying may throw a flood of retrospective light upon his character throughout life.” ${ }^{105}$ Hick argues that the act of dying at the very last moment of life may form a unique climax for him, as Jesus’ life on earth illustrates “the significance of his life and work as a whole.”106

As Schmitt notes, therefore, Hick’s interpretation of death is positive and naturalistic. ${ }^{107}$ This view sees death in the context of the will of God, which enables the person to move from one world to another and helps personal growth and development in the likeness of God. Hick, comparing two alternatives on the view of death, suggests that 166.

${ }^{102}$ Hick, God and the Universe of Faiths, 192.

${ }^{103}$ Robison, Life after Death? Christian Interpretation of Personal Eschatology,

${ }^{104}$ Hick, God and the Universe of Faiths, 192-193.

105 Ibid., 193.

106 Ibid., 194.

107 Schmitt, Death and After-Life in the Theologies of Karl Barth and John Hick, 145. 
"the Augustinian type of theology in which death is held to be the wages of sin should be replaced by an Irenaean type of theology which sees our mortality in relation to a positive divine purpose of love.” ${ }^{108}$ Thus, according to Hick, death must not be seen as a moment of eternal judgment but as a moment of transition to the higher level of existence, which leads to the following issue of what happens after the moment of death.

\section{Afterlife}

One of the major concerns of the world religions centers upon the notion of human survival of physical death, whether there is an afterlife. As Hick notes, a straightforward question that everyone asks is, "Do we live on after bodily death?"109 Knowing that the question of afterlife is not easy to answer, Hick discusses the origins for belief in afterlife and immortality, not only from a religious point of view, but also from empirical as well as rational points of view.

There is much empirical, particularly parapsychological, evidence "in the form of spirit communications through mediums, ${ }^{, 110}$ Hick argues, which seems to support the assumption that there is some kind of "human survival after death." ${ }^{\text {"111 }}$ Nevertheless, not being sure of whether it is a case of deceased persons trying to use a medium's

${ }^{108}$ Hick, Death and Eternal Life, 197.

${ }^{109}$ Hick, Disputed Questions in Theology and the Philosophy of Religion, 183. ${ }^{110}$ Ibid.

${ }^{111}$ William J. La Due, The Trinity Guide to Eschatology (New York: Continuum, 2004), 122. It should be noted that Hick has contributed at least one thing through his global theology of death. That is, as Donald G. Dawe notes, he put an end to the silent consensus that "there is no basis for belief in a continuation of personal existence after death." Dawe also says that "Hick ... look[s] upon the question of personal life after death not as an absurdity but as an issue open to philosophical analysis and empirical investigation” (Donald G. Dawe, "The End of the Silent Consensus," Interpretation 32, no. 1 [Jan. 1978]: 93). 
personation of them, or the medium receiving telepathic impressions, or a person deceased having a psychic factor (character traits and memories) for a while, Hick does not give a definitive answer on the survival of bodily death. Hick, quoting Robert $\mathrm{H}$. Thouless in answering the question "Do we survive bodily death?,” writes: "There seem to be many converging lines of evidence which suggest that [death] is the passage to another life, but we cannot yet be certain that this is the case. It is a future task of parapsychology to reduce to a minimum this uncertainty and to find out all we can about the nature of this future life." ${ }^{, 12}$ Hick insists, as Kai Nielsen notes, that the empirical evidence for "the survival of the death of our 'present' bodies in either a disembodied state or with a new resurrected body is ambiguous and uncertain." ${ }^{113}$ This does not mean that there is no afterlife, according to Hick. Though clearly being aware of the uncertain nature of empirical evidence of life after death, Hick argues, "The fact that we cannot as of now establish life after death by empirical evidence does not mean that there is no life after death. We must not mistake absence of knowledge for knowledge of absence!”114

Another line of argument from empirical evidence is observed in his discussion of burial practices of ancient people. Hick argues that the study of earliest evidences from all over the world shows that man "did not think of death as the cessation of existence." 115 The burial practices of ancient people show that "our prehistoric ancestors assumed that in some sense and in some form humans continue to exist after their

${ }^{112}$ Hick, Disputed Questions in Theology and the Philosophy of Religion, 187.

${ }^{113}$ Kai Nielsen, “A Response to John Hick," in Death and Afterlife, ed. Stephen T. Davis (New York: St. Martin’s, 1989), 199.

${ }^{114}$ Hick, Disputed Questions in Theology and the Philosophy of Religion, 187.

${ }^{115}$ Hick, Death and Eternal Life, 55. 
deaths." ${ }^{116}$ In other words, Hick claims there has always been a universal belief in “continued existence beyond death."117 This wishful thinking, however, cannot be an evidence for life after death.

Hick also argues from the rational and moral perspectives that a brief earthly life followed by a divine judgment of either eternal heaven or hell is not morally realistic. ${ }^{118}$ As La Due argues, "How could divine justice ever demand as a punishment for finite human sins an infinite penalty of eternal torture?"119 The recognition of the inequality of human existence leads Hick to develop a new eschatological model called pareschatology, which tries to solve the paradox. ${ }^{120}$ Thus, discussing the basic argument that after this limited earthly life comes an eternal judgment of God, Hick lists three reasons that this picture is unrealistic. First, a large proportion of human babies in the past "have died at birth or in infancy, so that for them it would seem that the purpose of life has remained

116 Ibid.

${ }^{117}$ Schmitt, Death and After-Life in the Theologies of Karl Barth and John Hick, 120.

${ }^{118}$ As Paul Helm notes, universalists, including Hick, insist that "since God is essentially and omnipotently loving it follows that he could not allow any human being to suffer an eternity of torments in hell" (Paul Helm, "Universalism and the Threat of Hell," Trinity Journal 4, no. 1 [Spr. 1983]). Hick’s basic argument is that if God is infinitely good, he cannot punish human sins with infinite punishment. There are many others who are in support of this argument. See Marilyn M. Adams, "Hell and the God of Justice," Religious Studies 11, no. 4 (Dec. 1975): 433-447; Jonathan L. Kvanvig, The Problem of Hell (New York: Oxford University Press, 1993); Charles Seymour, "Hell, Justice and Freedom,” International Journal for Philosophy of Religion 43, no. 2 (Apr. 1998): 69-86; Thomas Talbott, "Punishment, Forgiveness, and Divine Justice,” Religious Studies 29, no. 2 (June 1993): 156-168.

${ }^{119}$ La Due, The Trinity Guide to Eschatology, 122.

120 The notion of an all-good and all-powerful God with the existence of evil in the world is a sheer paradox to Hick. Thus, he has developed a new eschatological model that solves this contradiction based upon his Irenaean soul-making theodicy. 
unfulfilled." 121 Second, "the circumstances into which people are born . . . vary so greatly in their propitiousness for moral and spiritual growth that it is hard to see how we could be fairly assessed"122 in this short life. Third, in this short earthly life, only a "few people can be said to be morally fitted”123 for eternal salvation. The only acceptable explanation for the unfairness of human existence, Hick argues, "can be found in a life beyond death in which many or most of those injustices are remedied."124 This is a way of saying that salvation, as achieving certain moral norms, is not consonant with the traditional Christian theology of salvation, which put its emphasis on salvation by faith through grace. Though acknowledging this emphasis of faith, claiming that "the saved are those who believe in Jesus Christ as their Lord and Saviour and who put their trust in the efficacy of his atoning death,” Hick argues it is “arbitrary and implausible” in this pluralistic age. ${ }^{125}$ Thus, Hick made a move to consider other options from Hindu, Buddhist, Jain and Sikh traditions. Hick argues, "The basic thought here is that one lifespan is not enough for the transformation of human beings from the self-centredness of our natural state to the unity or community with the divine reality which is the ultimate aim of human existence.”126 The fact that there are only a few people fitted for eternal salvation led Hick to think that "one such natural span is not sufficient for our growth to a

${ }^{121}$ Hick, Disputed Questions in Theology and the Philosophy of Religion, 189.

122 Ibid.

123 Ibid.

${ }^{124}$ La Due, The Trinity Guide to Eschatology, 122.

${ }^{125}$ Hick, Disputed Questions in Theology and the Philosophy of Religion, 189. ${ }^{126}$ Ibid. 
total unitive or communitive centredness in the divine reality." ${ }^{127}$ In this way, Hick had to speculate that our present life would be followed by further lives in order to fulfill the ultimate purpose of human existence. Thus, Hick suggests we should consider seriously the basic Eastern option of a series of several afterlives, the doctrine of reincarnation taught by Buddhism and Hinduism. As Nielsen observes, “The eastern option . . . seems, on balance, if we view the matter purely morally, the more attractive option.”128 This led Hick to the main issue of this dissertation, pareschatology, which will be discussed in the following section.

Before discussing Hick’s pareschatology, it is helpful to mention some options of afterlife that he dealt with. He lists three major options in regard to the understanding of death and afterlife. First, the materialist, humanist view is that there is not any form of survival after death. Second, the Western and Christian version believes that there will be life after death in heaven. Third, the Eastern religions believe that there will be multiple lives after death in another form of existence. The first option Hick simply ignores, because he thinks it does not provide any idea of existence after death and is not included in his discussion. If Hick, as a pluralist philosopher who considers all forms of belief systems, does not consider this as an option, it is not consonant with his pluralistic hypothesis of world religion, which must include all systems as available options. Though being aware of the fact that the Western and Christian belief and the Eastern belief in regard to life after death are mutually exclusive, the first believing in the continuation of the individual personality after death either in heaven or hell and the second believing in the continual rebirth of person until it gains ultimate realization or

127 Ibid.

${ }^{128}$ Nielsen, “A Response to John Hick,” 198. 
nirvana, Hick suggests that "they point beyond themselves." ${ }^{129}$ Hick, after he has discussed both the Eastern and the Western beliefs, as Nielsen notes, has "something of the advantages of both while escaping their disadvantages." ${ }^{130}$ More will be discussed in the following section, but for now it needs to be noted that here Hick argues for what he calls "a third possibility, other than eternal-heaven-or-hell or repeated earthly reincarnations." ${ }^{131}$ The third possibility that he suggests is neither the Eastern nor the Western belief, but rather a combination of both. While the third possibility postulates "many spheres of incarnate existence" rather than only one, which is not in agreement with the Eastern belief, it also postulates "many lives” rather than only one, which is not in agreement with the Western belief. ${ }^{132}$

\section{Pareschatology as a Product of Pluralism}

Hick's eschatological model is a unique system and thus is not something that has a parallel system to be compared with. It is not based on any single system but rather has roots in major world religions' views on the subject. Thus it should be noted that Hick's pareschatology, what he generally calls a global theology of death, is a combination of major eschatologies of East and West. Knowing the profoundly obscure nature of the subject, Hick does not want to present theories in alleged certainties, but rather to "spell out possibilities." ${ }^{133}$ For this reason, Hick suggests that we "look seriously at all the main

\footnotetext{
${ }^{129}$ Hick, Death and Eternal Life, 28.

${ }^{130}$ Nielsen, “A Response to John Hick,” 199.

${ }^{131}$ Hick, Death and Eternal Life, 456.

${ }^{132}$ Ibid.

${ }^{133}$ Ibid., 22.
} 
theories and speculations and consider, so far as we can, their respective strengths and weaknesses_-even, in a very broad sense of the term, their relative probabilities."134 This attitude shows Hick’s apologetic way of doing theology. Trying not to start from any single religious vantage point, particularly Christianity, Hick argues, "I have tried not to be blinded by my own particular starting-point to insights and suggestions coming from beyond the Christian and western traditions." ${ }^{135}$ Furthermore, he invites Christians to make this same effort with him, and invites them to set aside certain prejudices against Eastern thoughts such as karma and rebirth. This pluralistic attitude led him to explore the new possibility of an eschatological model.

\section{Definition of the Term}

Before entering into the main discussion of pareschatology, it is worth noting how Hick defines the term. A somewhat odd and foreign term, "pareschatology” is adopted by Hick to express his own model of eschatology. It should be also noted that Hick distinguishes between eschatology and pareschatology. Comparing these two, Hick argues that while eschatology is the doctrine of the eschata or last things or the ultimate state of humanity, "pareschatology is the doctrine of the para-eschata, or next-to-last things.” ${ }^{36}$ Thus, as “the doctrine of man’s existence between bodily death and the ultimate state," ${ }^{137}$ Hick argues, pareschatology concerns not the ultimate state of

${ }^{134}$ Ibid. This does not mean that he has included all possible options for his discussion. Whereas Hick includes the Eastern and the Western models, he largely ignores some other models from African, Chinese, and South American religious traditions.

\footnotetext{
135 Ibid., 28.

136 Ibid., 22.

${ }^{137}$ Ibid., 240.
} 
humanity but "the human future between the present life and man’s ultimate state.”"138 That means its major concern is not centered upon the ultimate state of humanity as other eschatologies are, but rather on the human state between the moment of death and the ultimate salvation. Admitting the uncertainty of theories and speculations concerning the future destiny of man after death, Hick argues, "For if there is continued human existence after bodily death it is possible that its more immediate phases may bear sufficient analogy to our present state for some of our speculations about it to be not wholly misleading.” ${ }^{139}$ But the fact that pareschatology deals with events less remote, thus more immediate, does not guarantee that it is more easily known to us. It is equally uncertain what looks to be the destiny of man between eschatology and pareschatology. The nearness or remoteness of time really does not matter in the question of its certainty, because they both are beyond the access of human knowability. Hick's attitude toward the pareschatology, how vague it is and how uncertain it is, is well expressed in the following. He says:

The best that could be hoped is that in some of its more ultimate speculations the human mind is looking in what is in the most general sense a right direction, or at any rate that it is not looking in a totally wrong direction. But if we use this directional image it must be in terms of astronomical distances. To be looking in the direction of some unimaginably remote constellation, altogether beyond the range of our vision, may merely mean that I am, say, facing north rather than south! ${ }^{140}$

The analogy of looking at "some unimaginably remote constellation" to illustrate his model shows the very uncertainty and vagueness of the subject. If Hick is only interested in suggesting some kind of direction that leads to the destiny of humanity in
138 Ibid., 22.
139 Ibid.
${ }^{140}$ Ibid., 22-23. 
the future after death because of its uncertainty, I wonder how can we be sure that we are oriented in the right direction at all. The only possible direction that Hick's reasoning will lead could be his own conviction that there will be life after death, no more, no less.

Nevertheless, Hick presents the basic method to explicate possible human destiny beyond death. His agenda for the discussion, which I will also follow for my analysis of his model, is as follows: "What might it be to survive as a disembodied mind? What might the resurrection of the body, or of the flesh, mean? What might a spiritual body be? How can the idea of reincarnation be understood?"141 Hick's basic agenda can be as simple as saying that he will look for the evidences of afterlife, and two major options from Western and Easternstrands will be considered.

The Survival of the Disembodied Mind

As noted above, Hick's main goal in Death and Eternal Life is development of a universal or global theology of death and eternal life. In his steps to this objective, as Schmitt notes, Hick discusses Western and Eastern eschatological models, namely “pareschatologies, i.e. images and descriptions of what happens between death and the ultimate state." 142 The first issue Hick introduces in this section is "the survival of the disembodied mind," ${ }^{143}$ an issue that is rarely discussed.

${ }^{141}$ Ibid., 23. 131.

${ }^{142}$ Schmitt, Death and After-Life in the Theologies of Karl Barth and John Hick,

${ }^{143}$ Hick, Death and Eternal Life, 265-277. The survival of the disembodied mind basically concerns the life beyond death in terms of the immortality of the soul (Dilley, "Resurrection and the 'Replica Objection'," 459.). 
Though the belief that "after bodily death the mind continues to live goes back in western thought at least to Plato," ${ }^{144}$ little has been discussed systematically about "the notion of the survival of the disembodied mind” ${ }^{145}$ until Henry H. Price presented a paper titled "Personal Survival and the Idea of Another World." ${ }^{146}$ Hick states Price’s theory in three stages as follows. First, perceptions of life after death will be as similar as "perceptions in dreams." 147 As Hick notes, these perceptions will be "minddependent”148 and will come from mental images of one's life. That means our survival in the postmortem world will be a psychological one rather than physical. Second, while dreams are private matters in which there is no communication and interaction with other minds, in the world of the afterlife there may be "real communication and interaction with other minds" through what we call "extrasensory perception.” ${ }^{\text {"149 }}$ Thus there will be, as Hick notes, “continual telepathic activity, producing visual and auditory images, so that the resulting experience is just like that of seeing other people and hearing them talk." 150 Third, this postmortem world will "be dependent on the memories and the

${ }^{144}$ Hick, Death and Eternal Life, 265.

${ }^{145}$ Ibid. Henry H. Price calls this world "an image world, a dream-like world" (Henry H. Price, "Personal Survival and the Idea of Another World," in Classical and Contemporary Readings in the Philosophy of Religion, ed. John Hick [Englewood Cliffs, NJ: Prentice-Hall, 1970], 374, 376).

${ }^{146}$ Price, "Personal Survival and the Idea of Another World,” 370-393.

${ }^{147}$ Hick, Death and Eternal Life, 265.

${ }^{148}$ Ibid.

${ }^{149}$ Ibid., 266.

${ }^{150}$ Ibid. 
desires of the persons who experienced it,"151 because their memories and desires will determine the images they have.

However, as Hick notes, "Price cautions us against assuming that such a realm of wish-fulfillment would necessarily be unqualifiedly pleasant.”152 The spectrum of this psychological survival, as Hick notes, can range from solipsism—“a private-mentalworlds picture" 153 — at one extreme to another extreme notion of bodily resurrection, with Price's own conception standing in the middle. Hick contends that "there is . . . a tension between the idea of the formation of a post-mortem world by the power of desire and the idea that such a world is common to many minds in virtue of telepathic links between them.” ${ }^{154}$ The wish-fulfillment principle is consonant with the solipsistic picture while it is in conflict with the other extreme end of spectrum. Hick notes that one encounters difficulty if there are two or more individuals having identical or conflicting desires at the same time. Hick says:

It is not easy to combine the two suggestions that the post-mortem world is created by human wishes and that it is common to a great number of people. For desires inhere in individuals, and at the level of ordinary everyday wishes at any rate it may be presumed that no two individuals' and certainly no large community of persons' desires coincide sufficiently to be capable of being fulfilled in identically the same state of affairs. I do not believe that we can in fact imagine a coherent world created by the desires of a multitude of different people out of the material of their several sets of earthly memories. ${ }^{155}$

${ }^{151}$ Price, "Personal Survival and the Idea of Another World,” 385.

${ }^{152}$ Hick, Death and Eternal Life, 266.

153 Ibid., 267.

154 Ibid.

155 Ibid., 270. 
I wonder what would happen when wishes or desires of all the human beings conflict with one another in the postmortem world. If it is not likely that the desires of close friends are harmoniously related to each other, it is almost impossible to expect that all human beings’ wishes are in perfect harmony.

According to Price's psychological survival hypothesis, ${ }^{156}$ as Hick notes, it is hard to imagine how one can make any moral choices if our dreams are understood as “psychologically determined events.”157 But it seems that Price’s hypothesis does not want to claim our dreams are fully determined, and thus it is coherent to argue that "in a prolonged dream one might have to make ethical decisions”158 and thus experience moral development. This in turn requires that there must be inhabitants with whom postmortem minds interact in order to develop their moral characters. Hick argues that this kind of social environment would be "unreal and his commerce with other people delusory"159 in the postmortem world, because it is impossible to "imagine one continuing to develop to fulfillment isolated from other individuals.” ${ }^{160}$ However, this solipsistic picture is, as Hick notes, "transcended by the sharing by many minds in the imaging of a common

${ }^{156}$ Louis Dupré calls H. H. Price’s private dreamworld fashioned by the power of desires as a "science-fiction" theory (Louis Dupré, review of Death and Eternal Life, by John Hick, The Journal of Religion 58, no. 2 [Apr. 1978]: 218).

${ }^{157}$ Hick, Death and Eternal Life, 268.

158 Ibid., 269.

159 Ibid.

${ }^{160}$ Schmitt, Death and After-Life in the Theologies of Karl Barth and John Hick, 132. 
world” ${ }^{161}$ or "a common environment," 162 in which the memories and desires of numerous minds (thousands or millions) are pooled together.

Price suggests, as Hick notes, “a number of separate worlds created by groups of people with sufficiently similar memories or desires or both.”163 Contending that though the Old Testament presents the notion of a single world after death, and the New Testament views it as "the notion of a hierarchy of heavens existing at different spiritual levels," ${ }^{164}$ Hick argues for the direction that there is a series of worlds beyond death. This notion of many worlds is consonant with Hick's Irenaean type of theodicy that requires the person-making process to be continued in the lives beyond death, because "it is seldom completed by the time of bodily death." ${ }^{165}$ In other words, as Hick notes, "if the person-making process is ever to be carried through it seems that it must necessarily continue beyond bodily death. And this appears to require a real continuation of human life as a formative process.”" 166 However, Price’s hypothesis that "the understanding of reality developed by idealist metaphysicians might be true of the next world although not of the present one״167 makes the postmortem worlds created by man's desires hardly able to aid man in the person-making process. Disagreeing with Price, who understands the next world as different from the present one, Hick contends that "the next world would be

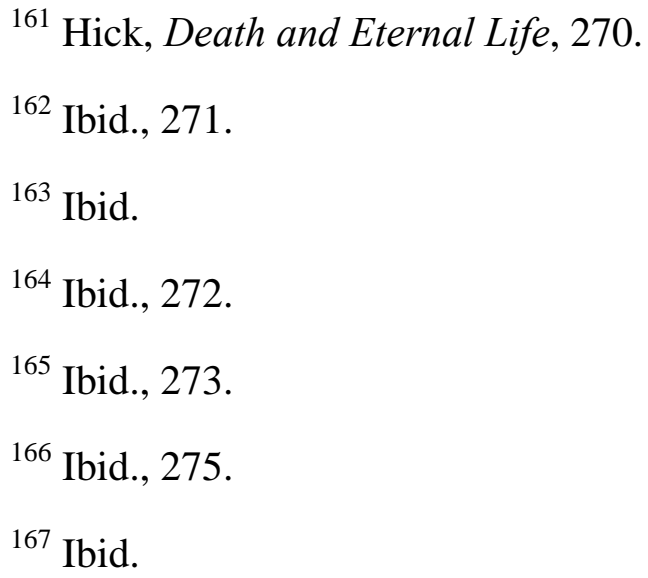


similar in nature to this world," 168 where the real person-making process is taking place because they are not two completely different worlds but have the same basic nature.

In concluding this section regarding the disembodied mind, Hick makes the following statements: “As soon as we try to conceive of the post-mortem existence of the disembodied mind we find that this is not after all truly disembodied. If there is no physical body inhabiting a physical world, then the mind must supply its own 'dream' body inhabiting a 'dream' world, the latter being as real to those who experience it as the former.”" 169 The next world either will be in a world with spatial dimensions or our mind will provide a world through dreams or imagination. Thus, Hick contends that the notion of the survival of the disembodied mind is not something radically odd but a special form of embodied postmortem existence. Though Hick is not clear about what this special form is, he argues that the next world has the same basic nature as ours, unlike Price's conception of a dream-like world of mental images. Accordingly, Hick does not expect that our life will continue beyond death in terms of immortality of soul, which led him to consider resurrection of the person. ${ }^{170}$

\footnotetext{
${ }^{168}$ Schmitt, Death and After-Life in the Theologies of Karl Barth and John Hick, 132.

${ }^{169}$ Hick, Death and Eternal Life, 276. Lynn A. de Silva compares man as the psycho-physical unity in Christianity with the Buddhist nāma-rūpa analysis of man. He says, "Just as in Buddhism man is a unity of näma-rūpa, so in the New Testament man is a unity” of body and soul (Lynn A. de Silva, The Problem of the Self in Buddhism and Christianity [New York: Barnes \& Nobles, 1979], 84).

${ }^{170}$ Dilley rightly notes that the majority of Christians "usually believed in an immortal soul which once inhabited a body, persists between bodies, and has a body reattached to it again in the resurrection world. Hick has always seemed to reject that model in his writings, opting instead for the view that a person is an "indissoluble psychophysical unity”” (Dilley, “Resurrection and the 'Replica Objection’,” 460.).
} 
The Resurrection of the Person

Admitting that the predominant view of humanity in contemporary science is that of an "indissoluble psycho-physical unity," ${ }^{171}$ in which only the empirical self is known and there is no room for soul in distinction from body, Hick wonders why Christian and Jewish belief in bodily resurrection is not getting enough attention in contrast to the Greek idea of the survival of a disembodied mind. Hick now draws our attention to a somewhat ignored conception of what he calls "the re-creation of the psycho-physical person" ${ }^{172}$ to have a clearer idea of life after death.

Before presenting his own “replica” theory, Hick briefly mentions the resurrection of the dead, presented by the apostle Paul. ${ }^{173}$ What he means by the resurrection of the dead is not "the resuscitation of corpses in a cemetery." ${ }^{174}$ When a person died he is extinct, as Hick rightly notes. By nature a human being is mortal, but God in his grace by the act of sovereign power either resurrects or recreates him. However, the manner of resurrection Hick advocates is "not . . . as the identical physical organism that he was before death, but as a soma pneumatikon ('spiritual body') embodying the dispositional

${ }^{171}$ Hick, Death and Eternal Life, 278. As Paul W. Gooch notes, Hick "belongs with those who think that survival can be discussed intelligibly without a belief in dualism." Gooch also notes that according to Hick "The Judaeo-Christian doctrine of the resurrection of the flesh or body is consonant with "the conception of man as an indissoluble psychophysical unity,' and this is the view with which he operates” (Paul W. Gooch, "On Disembodied Resurrected Persons: A Study in the Logic of Christian Eschatology,” Religious Studies 17, no. 2 [June 1981]: 201).

${ }^{172}$ Hick, Philosophy of Religion, 122.

${ }^{173}$ As John C. Yates notes, Hick finds the concept of an indissoluble phychophysical unity to be compatible with "Paul's doctrine that death means extinction and resurrection a re-creation” (John C. Yates, "Survival as Replication,” Sophia 27, no. 2 [July 1988]: 2-3).

${ }^{174}$ Hick, Philosophy of Religion, 123. 
characteristics and memory traces of the deceased physical organism." 175 Though he is discussing the conception of resurrection, a core Christian doctrine, Hick is not concerned with how the Scriptures deal with it, but attempts to present the subject in an intelligible way to today's mind.

One of the major problems that Hick acknowledges is how we are able to connect the earthly life and the resurrection life in terms of personal identity, which is an issue the Bible does not present, maybe because it is taken for granted. To present resurrection in an intelligible way Hick employs an idea that he calls the "replica” theory. ${ }^{176}$ Hick suggests three conjectural examples of a person disappearing from one place only to appear at the same time as a "replica" at another place. Hick assumes that this "replica" is believed to be the person who disappeared from one place. Hick uses the term "replica" in his attempt to explain the doctrine of resurrection in an intelligible way in distinction from replica, the word used to identify two simultaneously identical entities. He says: "If a putative 'replica' did exist simultaneously with its original it would not be a 'replica' but a replica; and if there were more than one they would not be 'replicas' but replicas. For 'replica' is the name that I am proposing for the second entity in the following case. A living person ceases to exist at a certain location, and a being exactly similar to him in all respects subsequently comes into existence at another location." ${ }^{\text {"177 }}$ Thus, as Schmitt notes, Hick's "replica" is "a second, identical entity [that] exists subsequent to an

${ }^{175}$ Hick, Death and Eternal Life, 279.

${ }^{176}$ This idea appears in Hick, Death and Eternal Life, 279-285; idem, Philosophy of Religion, 123.

${ }^{177}$ Hick, Death and Eternal Life, 283. 
original.” ${ }^{178}$ Hick develops his theory of "replica" in a series of three cases, which he claims to be the only logical possibilities.

First, Hick begins with the idea that someone living in this world suddenly disappears and the next moment comes into existence at another place. The person who appears in another place is exactly identical in both physical and mental characteristics. Hick argues, "There is continuity of memory, complete similarity of bodily features, including fingerprints, hair and eye coloration and stomach contents, and also of beliefs, habits, and mental propensities." ${ }^{, 179}$ Furthermore this "replica” person thinks of himself as being the same person who disappeared.

Second, Hick presents another imaginary case, which appears to be a step closer to the idea of resurrection. A person, instead of disappearing, dies and at the moment of death appears at another place with the same characteristics. Hick notes this would be even odder than the previous one because of the presence of a dead body in one place while a new "replica" is in another place at the same time. ${ }^{180}$ The one who died and the one who appeared must be the same person, argues Hick.

Hick presents still a third case, which contends that on a person's death the "replica" of him appears not at another place in this world, but "in a different world altogether, a resurrection world inhabited only by resurrected persons." ${ }^{\text {181 }}$ Hick’s speculation on this third possibility runs as follows:

${ }^{178}$ Schmitt, Death and After-Life in the Theologies of Karl Barth and John Hick, 133.

${ }^{179}$ Hick, Death and Eternal Life, 280.

${ }^{180}$ Ibid., 284.

${ }^{181}$ Hick, Philosophy of Religion, 124. 
It is, I think, manifestly an intelligible hypothesis that after my death I shall continue to exist as a consciousness and shall remember both having died and some at least of my states of consciousness both before and after death. Suppose then that I exist, not as a disembodied consciousness but as a psycho-physical being, a psycho-physical being exactly like the being that I was before death, though existing now in a different space. I have the experience of waking up from unconsciousness, as I have on other occasions woken up from sleep; and I am no more inclined in the one case than in the others to doubt my own identity as an individual persisting through time. ${ }^{182}$

This third example is very close to the conception of resurrection in the Bible, which teaches death figuratively as sleeping and resurrection as waking up. This assumption is a model that Hick explores, in order to "conceive of the divine re-creation of the embodied human personality." ${ }^{183}$ Thus, Hick argues there is no question of affirming self-identity; that resurrected person would no more doubt his own identity than we do now. ${ }^{184}$ Hick also claims that that resurrected person would know that his existence is "post-mortem," because it is conceivable that "the space of the resurrection world should have properties which are manifestly incompatible with its being a region of physical space as we know it." ${ }^{185}$ Hick’s main reason for arguing that the person is sure that he is postmortem is that the laws of space in which he was before death are not compatible with the first and the second cases. The third example is closest to the view that Hick is proposing concerning the conception of resurrection, yet it is not completely identical with it. Admitting that a resurrected person comes into existence in a different world with the same personal identity as before his death, Hick still tries to show that the

${ }^{182}$ Hick, Death and Eternal Life, 285.

${ }^{183}$ Hick, Philosophy of Religion, 124.

${ }^{184}$ In regard to the matter of my identity, Yates argues that it is not how I am treated and understood by others, but "how I may reasonably treat my own identity" (Yates, "Survival as Replication,” 5).

${ }^{185}$ Hick, Death and Eternal Life, 286. 
idea of life in a resurrection world is spatially and physically unrelated to this world. Hick argues, "This world occupies its own space distinct from that with which we are now familiar." 186 Therefore, an object in this world is "not situated at any distance or in any direction from the objects in our present world, although each object in either world is spatially related to every other object in the same world.”187 The resurrection world is not somewhere that we can locate in this universe, but it is in another world to which we cannot travel, because there is no space between them. ${ }^{188}$

The next question that comes to mind is the time relationship between the two worlds. Arguing against Alan Olding's contention that "no time elapses between the death of the physical body and the appearance of the resurrection body ... because they are not temporally related," and thus "the death-bed scene is not a past event," ${ }^{189}$ Hick contends that the resurrected person remembers his moment of death and therefore his death-bed must have been a past event. ${ }^{190}$ In other words the "replica" of Mr. X remembers his dying, because his death-bed is an event he experienced in the past. Hick contends that there is "a single time sequence in which events can occur simultaneously

${ }^{186}$ Hick, Philosophy of Religion, 124.

${ }^{187}$ Ibid.

188 John Hick, "Resurrection Worlds and Bodies,” Mind 82, no. 327 (July 1973): 409. Hick argues that "the resurrection world is not just further away from America than, say, Australia is, but is not at any distance great or small. Consequently it is logically impossible to move through the space between them (since there is none)" (ibid.). As a result of speculation, Hick's resurrection world, thus, is outside the realm of this present world in which we live.

${ }^{189}$ Alan Olding, "Resurrection Bodies and Resurrection Worlds," Mind 79, no. 316 (Oct. 1970): 584.

${ }^{190}$ Hick, Death and Eternal Life, 290. 
in different spaces.”191 He speculated on the possibility of a singular time in plural spaces as follows: "Presumably the divine mind, conscious of all spaces and of the elapse of singular time, would be aware of the temporal relationship between events in different spaces. But the inhabitants of a given space could only be aware of the continuity of time through spaces as an inference from their own memories of life in another space.”192 Therefore, the "replica” or resurrected person in space two comes into existence after his death in space one. There is no direct evidence of his having reappeared in space two available besides his own memory. Thus, as I mentioned earlier, this contention of memory has a key role in the identification of Mr. X in space one and his “replica” or what Hick calls Mr. $\mathrm{X}^{1}$ in space two. In other words, this memory of the previous life confirms the self-identity of Mr. $\mathrm{X}^{1}$ - that he still is Mr. X. ${ }^{193}$

Granted that the 'replica’ of Mr. X appears in another space at the same time as Mr. X’s physical body dies, does he appear as he was at the last moment of life before his death in this world? Acknowledging the problem of losing all the memories that he had acquired since that age when supposing that the resurrection body is a "replica” of his earlier life with full health and vigor, Hick argues the resurrection body is created in the condition of the earthly body "perhaps at the last moment of conscious personal life.”194 Furthermore, he claims that old people will go through "a process of growing physically

\author{
191 Ibid. \\ 192 Ibid. \\ 193 Hick, "Resurrection Worlds and Bodies,” 412. \\ ${ }^{194}$ Hick, Death and Eternal Life, 294.
}


younger to an optimum age," ${ }^{195}$ which makes him self-contradictory because he mentioned that he was against the idea of a "replica" of earlier life rather than at the moment of death. The biggest issue Hick deals with here is whether the resurrected person in another world preserves a full personal identity. ${ }^{196}$ Though the resurrected person may go through some changes which are not seen in this world, argues Hick, as "an indissoluble psycho-physical unity ... he must begin his resurrection life as identically the person who has just died." ${ }^{, 197}$ However, as John C. Yates notes, regarding my own "replica" though others may treat it as me, I wonder "how I may reasonably treat my own identity." 198 Hick’s "replica” lacks a certain continuity with the pre-mortem person with which it is supposed to be the same individual.

Hick's goal in this section is to argue that the discussion has accomplished "the conceivability of resurrection as the divine re-creation of the individual after his earthly death as a total psycho-physical 'replica' in another space." ${ }^{199}$ However, Hick admits that this "replica" theory is only "the most accessible of a range of possibilities," 200 and it is a speculation of divine reconstitution in another world. He also argues that in the resurrection world we still have bodies as our outward reflection of our inner nature, not

${ }^{195}$ Hick argues that "instead of its immediately or soon dying, we must suppose that in its new environment it is subjected to processes of healing and repair which bring it into a state of health and activity” (ibid.).

${ }^{196}$ Hick postulates "full initial bodily similarity between the resurrected person and the pre-resurrected person” (ibid.).

${ }^{197}$ Hick, Death and Eternal Life, 294.

${ }^{198}$ Yates, "Survival as Replication,” 5. Yates insists that "Hick's 'replica' then is nothing more than a replica, an imitation" (ibid.).

${ }^{199}$ Hick, Death and Eternal Life, 293.

${ }^{200}$ Ibid., 295. 
in the same way as we do in this world, but in ways quite different from this world. ${ }^{201} \mathrm{He}$ does not go further with a more detailed description of these bodies in the resurrection world, as Schmitt notes, beyond which “only imagination could carry man.”202

\section{Reincarnation}

The doctrine of reincarnation originated from religions in India such as Hinduism and Buddhism and is becoming popular in the Western world in different forms. The reason for Hick's preference for reincarnation as one of the serious eschatological options is that it may be able to answer the annoying problem of inequalities that are experienced in society. Hick's basic reasoning behind the preference of survival after death in terms of, particularly, reincarnation is based upon his dealing with the problem of evil in Evil and the God of Love, namely, theodicy. The problem of evil in human existence is a hardto-deny fact that is in appears to be in contradiction with a Christian notion of allpowerful agape God. ${ }^{203}$ The way Hick finds the solution to this paradox is by adopting the Irenaean anthropological insight of double creation of human being, evil is not only

${ }^{201}$ It is noteworthy to mention Yates's question and answer concerning identity of this replica, whether it is me. He says, "Since what I want to know when I ask the questions, 'Will he be me?,' is whether my personal experience will continue, I must conclude that the answer is 'No!'. Hick's 'replica' then is nothing more than a replica, an imitation, and I have no reason to be interested in his future" (Yates, "Survival as Replication,” 6.). 134.

${ }^{202}$ Schmitt, Death and After-Life in the Theologies of Karl Barth and John Hick,

203 The classical problem of theodicy that deals with the issue of evil in view of an omnipotent and all-loving God is one of the basic foundations of Hick's new eschatological approach called 'pareschatology.' The basic reasoning of theodicy, as Hick states, is as follows: "If God is perfectly good, He must want to abolish all evil; if He is unlimitedly powerful, He must be able to abolish all evil: but evil exists; therefore either God is not perfectly good or He is not unlimited powerful” (Hick, Evil and the God of Love, 5). 
permitted or helpful but also is inevitable and even necessary for the "soul-making" process. ${ }^{204}$ Thus, the backbone of Hick's search for a new eschatological model through a global theology is his understanding of theodicy that a good and almighty God is not in contradiction with the existence of evil because evil is a part of human creation.

Accordingly, as Schmitt notes, Hick’s theory of afterlife, particularly reincarnation, "attempts to solve one basic problem—-how it is possible to account for the physical and social inequalities which invariably accompany birth into this world.”205 While Western people have a hard time answering human inequalities such as being born in poverty, or with birth defects, or as a slave and so on. Indian religions offer an alternative answer that "we all lived before and that the conditions of our present life are a direct consequence of our previous lives. ${ }^{206}$ Rather than appealing to the arbitrary, random, and unjust will of God in the inequalities of human existences, the reincarnation doctrine teaches that we are reaping now what we have sown in the past. In other words, the doctrine of reincarnation relieves God of a traditional theodicy problem that if God is all-powerful and all-good, why there is evil in the world and, instead, "make[s] our karma responsible." ${ }^{207}$ According to this conception one has lived before and will continue to live in another life, which naturally presupposes physical resemblance. One also must be able to remember his experiences of the past lives, as Hick notes, "even

${ }^{204}$ Ibid., 236, 380.

${ }^{205}$ Schmitt, Death and After-Life in the Theologies of Karl Barth and John Hick, 134.

${ }^{206}$ Hick, Death and Eternal Life, 301.

${ }^{207}$ Ibid., 302. 
though in fact the traumas of death and birth generally erase such memories, repressing them to a deep and normally inaccessible level of the unconscious.”208

\section{Basic Conception of Reincarnation}

One who is supposed to be reborn after his death must have the same identity in order for him to be conceived as the same person. Hick has discussed three strands of continuity—memory, bodily continuity, and psychological continuity ${ }^{209}$ — which constitute the identity of a certain person through time. Hick dismisses the first two, namely memory and bodily continuity—because they do not assure anyone of reincarnation. He claims that $99.9 \%$ of people never recall their experiences of the previous lives, which confirms that the memories of previous life cannot be the evidence of the connecting thread for reincarnation. The fact that one may change sex, race, and turn into other species ${ }^{210}$ in the following existences, as Hick notes, confirms that there can hardly be said to be physical connection or continuity between these existences.

The third suggestion offered by Hick in favor of continuity is "the psychological continuity of a pattern of mental dispositions, ${ }^{211}$ which claims that if the reincarnated person Mr. $\mathrm{X}^{1}$ has the same personality traits as $\mathrm{Mr} . \mathrm{X}, \mathrm{Mr} . \mathrm{X}^{1}$ is the reincarnation of $\mathrm{Mr}$. X. Though psychological continuity may be able to solve the problem of sexual, racial ,and special changes between existences, as Schmitt notes, "to accommodate such a diversity of possibilities the pattern of mental dispositions would necessarily be so

208 Ibid.

${ }^{209}$ Ibid., 306-307.

${ }^{210}$ One may be born as a man or a woman, sometimes in another race, and sometimes even as an animal or an insect. See ibid., 306.

211 Ibid., 307. 
general as to be applicable to thousands of persons." ${ }^{212}$ In other words, general similarities of character would never lead us to identify the two persons as the same person. In regard to this view Hick says: "Many people are kind and thoughtful, or have artistic temperaments, or are proud and intolerant; but so long as they are distinct bodily beings with different streams of consciousness and memory the fact that two individuals exhibit a common character trait, or even a number of such traits, does not lead us to identify them as the same person." 213 Therefore, Hick admits that psychological continuity is far too vague and broad to accept as evidence for the reincarnation doctrine.

Failing to provide evidences for reincarnation with these three strands of continuity between two existences, Hick appeals back to the credibility of memory in a slightly different way. Hick contends that "there is an unconscious thread of memory linking”"214 the various lives which will "remain latent until a final moment of total recall as the reincarnating soul at last attains to enlightenment," ${ }^{215}$ because memories, whether conscious or unconscious, link with a particular life or lives rather than connecting lives with similar character traits. Thus, as Schmitt notes, Hick "rescues the idea of reincarnation before it sinks.”216 134.

212 Schmitt, Death and After-Life in the Theologies of Karl Barth and John Hick,

${ }^{213}$ Hick, Death and Eternal Life, 307.

${ }^{214}$ Ibid., 308.

${ }^{215}$ Ibid. Agreeing with both contemporary scientists and Western philosophers that man is "an indissoluble psycho-physical unity," Hick sees the soul as not something that can be separated from body, but something inseparable from body. In this way, Hick understands the concept of soul as something identical to mind (ibid., 278). 134.

${ }^{216}$ Schmitt, Death and After-Life in the Theologies of Karl Barth and John Hick, 
Before closing the discussion, Hick revisits his early formulation that the idea of reincarnation solves the inequality problem of human birth and life. According to the basic idea of reincarnation that our present life is the consequence of previous ones, "the inequalities of our present life are endlessly postponed and never achieved.”217 Thus, Hick admits that the doctrine of reincarnation does not solve the dilemma of the inequalities of human circumstances, because the solution is only postponed to infinity. Reincarnation either requires explanation if there is a first birth, or postpones the solution to infinity if there is infinite regression of births. ${ }^{218}$

\section{Rebirth in Buddhism}

Another Indian-originated religion which teaches a doctrine of reincarnation is Buddhism. Though discussing the similar doctrine in Hinduism, Hick notes that Buddhist scholars “prefer the term 'rebirth' to 'reincarnation.",219 At death the nama-rupa (literally "name-form” but best translated as “embodied existence”), ${ }^{220}$ the composite of the physical body and the mental element, disintegrates. Hick notes that at death man as a psycho-physical being disintegrates and ceases to exist. The nama-rupa does not survive death, and is not born again. Yet an aspect of him does continue to exist, not eternally but until it has expended itself "at the end of many lives." 221 The question is: What is it that

${ }^{217}$ Hick, Death and Eternal Life, 309.

${ }^{218}$ Ibid. So far I have dealt with Hick's description of the basic conception of reincarnation within Hinduism. Though Hick deals with some other versions of Hinduism and its teachings about reincarnation - the Vedantic theory of Reincarnation-I will omit it because it is not relevant to the present discussion.
${ }^{219}$ Ibid., 331.
${ }^{220}$ Ibid., 343, 345.
${ }^{221}$ Ibid., 343. 
survives if it is not the psycho-physical individual? Hick notes that it "consists of a system of character dispositions, the karmic deposit of former lives, animated and propelled onwards by the power of craving."222 Thus that which continues is not a conscious being but "a formation of non-conscious psychic elements,” which is a "lifecraving system of dispositions" ${ }^{223}$ equivalent to the linga sharira ${ }^{224}$ of Vedantic theory. The linga sharira — which Hick equates with "psychic factor" 225 or translates as "spiritual body”226 — will survive physical death and enter the womb and give its basic character to a new embryo. Thus, in Buddhism the last moment of thought in the dying person is very important, as Schmitt notes, because "the first moment of thought in the new stream of life stands in direct causal sequence to" it. ${ }^{227}$ In other words, the thought of the last moment of death determines the character of the new birth. The first thought of the new life stream which Hick calls “relinking consciousness”228 need not necessarily be a conscious thought but rather "a complex dispositional impulse, carrying a set of basic character traits and a store of unconscious memories.”229

${ }^{222}$ Ibid., 343-344.

223 Ibid., 344.

${ }^{224}$ The linga sharira (subtle body) in Vedantic Hinduism is not understood as a material entity in Western terms. As Hick notes, "the subtle body must accordingly be described as a mental rather than as a physical entity” (ibid., 315).

${ }^{225}$ Hick, Death and Eternal Life, 344. Hick notes that he borrowed the term “psychic factor” from C. D. Broad.

${ }^{226}$ Hick, Disputed Questions in Theology and the Philosophy of Religion, 194.

227 Schmitt, Death and After-Life in the Theologies of Karl Barth and John Hick, 135.

${ }^{228}$ Hick, Death and Eternal Life, 346.

${ }^{229}$ Ibid. 
Thus, reversing the previous arguments in favor of rebirth in human life, Hick contends that the rebirth or reincarnation may not necessarily occur in our earthly life, which in turn suggests the possibility of the reincarnation into other worlds. Hick notes that rebirth or what he calls "rebecoming"230 can occur in any of the following worlds such as "the kama-worlds (sense worlds), which include our earth, purgatory, and the nearer deva (angel)-worlds; the rupa-worlds (worlds of visible form though not sense) which are the further Brahma and supra-Brahma spheres; and the arupa-worlds (incorporeal worlds of thought).”231

In order to argue for his thesis of an other-worlds hypothesis, Hick uses two arguments. First of all he claims that the assumption of other worlds makes it intelligible that reincarnation in this world does not always follow right after death. ${ }^{232}$ Second, it also makes it intelligible that the human population of the earth has always increased perhaps because there are beings from other worlds being brought into our world. ${ }^{233}$ The hypothesis that a person may not be reincarnated again into this world becomes an interesting possibility within Hick’s pareschatology. What then happens to the persons who will not be reincarnated? This question will be answered in his own suggestion on the possible pareschatology in the following section. According to his previous discussion, as Schmitt notes, “somebody will of necessity be required to bear the consequences of the decisions and actions" done on earth because of "the idea of a collective karma, i.e. the collective, qualitative sum of volitional activity” in the previous

$$
\begin{aligned}
& { }^{230} \text { Ibid. } \\
& { }^{231} \text { Ibid. } \\
& { }^{232} \text { Ibid. } \\
& { }^{233} \text { Ibid. }
\end{aligned}
$$


life. ${ }^{234}$ Hick argues that this way of interpreting reincarnation in ethical and social terms is in the Western mind a demythologization. ${ }^{235}$ It also should be noted that there is a major weakness in the theory of reincarnation because it has difficulty explaining why “babies are not born with adult egos”236 who had died at an old age.

\section{Christianity and Reincarnation}

Though Hick knows that the doctrine of reincarnation has never been a Christian doctrine because it is not compatible with Christian truth, he argues that this does not automatically discredit it as one of the options. Hick lists four reasons why Christians view the doctrine of reincarnation or rebirth as not consonant with Christian truth, with his own arguments against them. First, Hick argues that "reincarnation is not taught in the New Testament,"237 and thus early church fathers did not accept it as orthodox Christian doctrine. However, Hick adds that they were against "the popular conception of reincarnation but very little against the more sophisticated versions” ${ }^{\text {238 }}$ in Hinduism and Buddhism. In other words, according to Hick, they would have responded differently if they had known the more sophisticated version of reincarnation. Second, Hick notes that “Christianity attributes an absolute importance to this present life as the period of grace in 136.

${ }^{234}$ Schmitt, Death and After-Life in the Theologies of Karl Barth and John Hick,

${ }^{235}$ Hick, Death and Eternal Life, 359.

${ }^{236}$ Ibid., 363.

${ }^{237}$ Ibid., 366. Hick notes specifically that John 9:2-3 is an evidence that Jesus and the New Testament were not sympathetic to this doctrine (ibid., 368).

${ }^{238}$ Ibid., 369. 
which our eternal salvation or damnation is to be determined," 239 so there is no room for the idea of reincarnation. He, however, sees the possibility of pareschatology in the theology of Ireanaeus, who viewed human beings in the process of being made in the "likeness" of God. Third, Hick notes that the idea of "metempsychosis is fundamentally at variance with the Christian doctrine of the resurrection of the body.”240 Hick argues that these two doctrines conflict superficially, yet they agree in their view of the human being as “a psycho-physical unity,” thus able to live again as an “embodied being.”241 Thus, he insists that reincarnation and resurrection are "superficially different but more fundamentally in agreement."242 Fourth, Hick argues that there is a radical opposition between Christian belief and the doctrine of reincarnation because reincarnation damages the uniqueness of Christ's death on the Cross. ${ }^{243}$ Hick argues against this and says, "For there is no logical connection between the idea that Christ died once only for the sins of the world and the idea that men have only one life in which to accept the benefits of that atoning death."244 As he implies, if we take Ireanaean thought that there is not necessarily one life that gives only a lifetime chance for salvation, Christ's unique atoning act could

${ }^{239}$ Ibid. As Schmitt notes, Hick criticizes this view "on the basis of Irenaean and even Augustinian theology,” claiming that there is a Catholic doctrine of purgatory, "an intermediate state between this present life and the ultimate heavenly state" (ibid., 370).

240 “Metempsychosis,” The Oxford Dictionary of the Christian Church, ed. F. L. Cross (New York: Oxford University Press, 1958), quoted in Hick, Death and Eternal Life, 371.

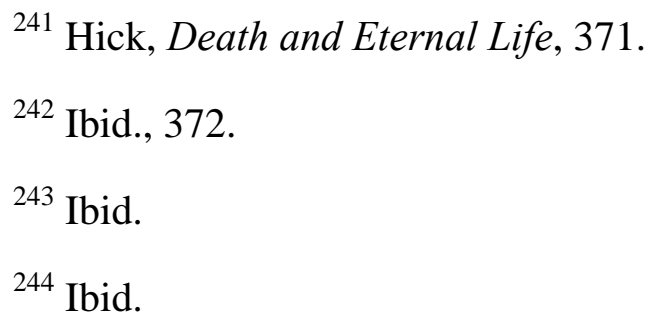


be compatible with the idea of reincarnation. Though Hick never argues that reincarnation is a Christian doctrine, all he wants to say is that this idea of reincarnation is not completely incompatible with Christian gospel. In other words he would like this theory to be a possible option for further development of pareschatology.

\section{Memories and Reincarnation}

In Hick’s argument on the issue of identity of persons between this world and life after death, as he notes, actual or latent memories of previous lives are essential to credibility of the reincarnation doctrine. Though admitting the limit of the task due to its unverifiability based on Ian Stevenson’s research, ${ }^{245}$ Hick draws “attention to two particularly puzzling features” that are suggestive of reincarnation. ${ }^{246}$ The first puzzling feature is related to children. Hick notes that children who spontaneously remember their previous lives tend to forget them as they grow and are "more fully absorbed in their present life.”247 Thus Hick contends the memories of children concerning previous lives tend to support the reincarnation hypothesis. The second puzzling feature is that the majority of these cases suggestive of previous-life memories come from cultures where “reincarnation is an accepted belief." 248 As Schmitt notes, "cases of putative

245 See Ian Stevenson, Twenty Cases Suggestive of Reincarnation, Proceedings of the American Society for Psychical Research, vol. 26 (New York: American Society for Psychical Research, 1966).

${ }^{246}$ Hick, Death and Eternal Life, 374.

247 Ibid.

248 Ibid., 374-375. Hick notes, “Stevenson’s researches also indicate a concentration of apparent previous-memories in cultures in which reincarnation is a matter of general belief. His international census of cases suggestive of reincarnation, as reported in 1966, contained nearly six hundred cases. About half of these came from the Hindu and Buddhist cultures” (ibid., 375). 
reincarnation generally occur in cultural contexts"249 where the doctrine of rebirth or reincarnation is taken for granted. On the basis of all these ambiguities and uncertainties, Hick at this stage hesitates to draw a clear conclusion on the issue, but rather he makes “an interim verdict of Not Proven.”250 Hick argues that the evidences available at present do not force us to accept the reincarnation hypothesis. At the same time it does not mean that the evidences are so weak that we can ignore them. Additionally, Hick also insists that memories of past lives claimed by yogis, arahats, and other liberated persons who claim to have power to remember their past lives are not able to be proven. For instance, Hick notes, according to the Fatakas of the pali canon, Buddha remembers his own past 550 lives. ${ }^{251}$ But there is no way to test the claims made by these people. After a lengthy discussion on the issue of continuity of memory in reincarnation, Hick concludes, "It is ... the claim that successive lives are linked together by an actual or latent continuity of memory that makes reincarnation a factual hypothesis, open in principle to confirmation or disconfirmation.,252

Furthermore, Hick also investigates the issue whether there is any relationship between the reincarnation hypothesis and the process of genetic codes. The fact that the same basic character dispositions reappear again and again in different individuals could be understood as "a mythological way of referring to the continuity of the genetic 137.

${ }^{249}$ Schmitt, Death and After-Life in the Theologies of Karl Barth and John Hick,

${ }^{250}$ Hick, Death and Eternal Life, 375.

${ }^{251}$ Ibid., 380.

${ }^{252}$ Ibid., 381. 
material through the ages,”253 notes Hick. It is true that basic character traits are repeated and observed in many different individuals over time. However, Hick argues that the incompatibility of the doctrine of reincarnation with genetic science is seen, for instance, in the fact that "whereas heredity always goes directly from parents to their offspring, the process of reincarnation never does - children cannot be reincarnations of their own parents.” ${ }^{254}$ After investigating any relationship between genetics and reincarnation, Hick draws a conclusion that genetic codes offer no positive support to the reincarnation hypothesis. ${ }^{255}$ On the other hand, genetic theory also is too incomplete to disprove reincarnation.

In his conclusion on reincarnation, Hick hesitates to make a clear statement whether the doctrine is true or not. However, with vagueness and uncertainty he draws a preliminary conclusion concerning the doctrine of reincarnation as follows.

There are forms of reincarnation doctrine which may be broadly true pictures of what actually happens. It may be true ... that an eternal 'soul' or 'higher self' lies behind a long series of incarnations, and that in the consciousness of that 'real self' all these incarnations are linked together in a way which is not evident to any of the temporary persons who form the series-one of whom I now am. Or it may be true ... that units or 'packages' of karma (as distinguished from 'higher selves') produce a series of persons, one of whom is me. . . . But on the other hand, whilst this may be a true account of what is happening, such a theory lacks the moral and practical significance of the more popular pictures of reincarnation, according to which I - the conscious self now writing these sentences - have lived before and shall live again and am in the course of my present life reaping what I have sown in the past and sowing what I shall reap in the future. . . . This popular conception is what is believed, or vaguely assumed, under the name of reincarnation or rebirth in Hindu and Buddhist cultures. Such a popular conception has a limited support from the alleged memories of former lives discussed [earlier], but tends to be unconvincing to those outside these cultures,

$$
\begin{aligned}
& { }^{253} \text { Ibid., } 382 . \\
& { }^{254} \text { Ibid., } 383 . \\
& { }^{255} \text { Ibid., } 388 .
\end{aligned}
$$


and indeed seems to be slowly losing its hold even within them [emphasis added]. ${ }^{256}$

The Third Possibility

In the concluding part of the book Death and Eternal Life, Hick tries to wrap up what he has discussed earlier and to reach "a possible human destiny." 257 Unlike the conventional approach to human destiny, Hick’s discussion of the issue includes not only eschatology but also pareschatology. Hick notes that two things must be assumed in order for his argument to work. First, there must be "the persisting self-conscious ego"258 which will survive bodily death. Second, there must be a possible state for pareschatology or "intermediate state or states between this life and the end of our temporal existence” for the majority of people because they hardly attain perfection in this world. ${ }^{259}$ Thus Hick's question to ask is, What is going to happen in the next stage of a life journey?

Before presenting his own picture of what will happen after death before final salvation, Hick discusses briefly "what is offered in the Tibetan Book of the Dead and in western mediumistic communication.”260 Hick tries to include as many options as possible from East and West, yet not all are included in fact.

${ }^{256}$ Ibid., 391-392.

${ }^{257}$ Ibid., 397-466. Hick deals with the issue in his final section of the book, entitled "Part V. A Possible Human Destiny."

${ }^{258}$ Ibid., 399. However, this self-conscious ego Hick insists is not an immortal soul at all as some traditions understand it, but rather a psycho-physical unity that continues to exist after death.

${ }^{259}$ Ibid.

${ }^{260}$ Ibid., 400. 


\section{The Bardo World}

Hick's first discussion is taken from the Bardo Thödol, in English Tibetan Book of the Dead. The bardo is a combination of two words, bar meaning "between," and do meaning "two,” which represents "the state between death and rebirth.”261 As Hick notes, there are three bardo states, which show the soul or conscious mind going between death and its return to a new body. In the first bardo state the soul detaches itself and is surrounded by blinding light, "Radiance of the Clear Light of Pure Reality.”"262 The soul will have an opportunity for immediate entry into nirvana at this moment, but "only those who have come close to the complete purification of the self" have this chance. ${ }^{263}$ In the second bardo stage, the soul is exposed to good and evil powers. The self will encounter good power and have a chance to go into "Buddha-worlds," but the impure self will face evil power and experience judgment in various hells. ${ }^{264}$ After this experience, at the third bardo state, as Schmitt notes, the unsaved soul "will be joined to another body and world corresponding to its karma.”265 Thus the soul will go back to the cycle of birth and death again. It must be noted that in this process, as Hick notes, "the mind creates its own post-

${ }^{261}$ Ibid. Comparing bardo state with Western Spiritualism, Hick says, "there is no new sensory input and the environment of which we are aware is a mind-dependent projection of our own memories, desires, fears and beliefs. Such a dream-like phase would seem to correspond with what in Western Spiritualist literature has been called illusion- and/or Summer-land" (Hick, Disputed Questions in Theology and the Philosophy of Religion, 195).

${ }^{262}$ Hick, Death and Eternal Life, 400.

263 Ibid., 401.

${ }^{264}$ Ibid., 401-403.

${ }^{265}$ Schmitt, Death and After-Life in the Theologies of Karl Barth and John Hick, 138. 
mortem world in accordance with its beliefs," 266 which implies that it still is in the soulmaking process.

\section{The “Next World" in Western Spiritualism}

The basic idea of Western spiritualism, as Hick notes, is that there are some cummunications emanating from persons who have died, which they believe to be describing "the life to come." 267 According to Western spiritualist literature "there is a psychic double of the body, an astral or etheric body, which detaches itself at death from the physical corpse until the connecting links between them are broken.”268 This astral body either sleeps or is in a half-conscious state, understood as a confused borderland between this world and the next one, called "hades" in Western spiritualism. Hick notes that the overall structure of Western spiritualism centers upon the idea of seven planes of existence as follows:

There are said to be seven planes, the lowest being that of physical matter; the next, the plane of 'hades,' described as a confused borderland between earthly life and the next world; then the plane of illusion, in which most souls spend a considerable time; and then beyond this a plane of 'colour', a plane of 'flame', and plane of 'light', and finally a plane beyond time in which souls become one with God. ${ }^{269}$

These seven planes of existence represent one’s journey after death till the final encounter with God. It should be noted that the third plane, the plane of illusion, is often called "Summer-land, or the Memory-world,"270 in which some have a delightful

\footnotetext{
${ }^{266}$ Hick, Death and Eternal Life, 403.

${ }^{267}$ Ibid., 404.

268 Ibid.

${ }^{269}$ Ibid., 406.

${ }^{270}$ Ibid., 405.
} 
experience (no more illnesses, no bodily deformities experienced) while others have a purgatorial experience (only darkness experienced). This stage of plane of illusion, argues Hick, "represents only a phase in what is intended to be the upward movement of the soul., ${ }^{271}$ In other words, this idea of the planes of existence shows the transition or the movement from one level of existence to the higher one, that is, "a movement towards a goal." ${ }^{272}$ This idea of movement towards a goal implies that there is a purpose in life. For this reason, Hick points out that the basic thought concerning death and afterlife is teleological, showing our existence heading towards "human perfection, man’s full humanization, the total realization of the potentialities of finite personal life or ... man's divinization." ${ }^{273}$ Accordingly, preparing a way for his idea of pareschatology to be considered as an intelligible hypothesis, Hick contends that human life is a soul-making process, which lies far beyond our present existence in this world.

\section{Critique of the Idea of the Immortal Ego}

If life has a goal to reach, a full humanization or human perfection, argues Hick, as we perceive it, "such a completion is very seldom (if ever) achieved in the course of this present life." ${ }^{274}$ In this present life, as Hick notes, only a few people advance enough for human perfection, while most advance a little, which is not enough for them to reach human perfection. And there are still others failing to advance at all, or even becoming

${ }^{271}$ Ibid., 406.

${ }^{272}$ Ibid., 407.

${ }^{273}$ Ibid. LeRoy Moore calls this as "a developmental, morally didactic three-stage eschatology”: (1) egocentric stage; (2) pareschatological stage; (3) eschatological stage (Moore, 90).

${ }^{274}$ Hick, Death and Eternal Life, 408. 
worse who will need more time for a full humanization. I wonder what state this perfected humanity is and doubt that we can easily find some cases in the real world. Hick adds, “Accordingly, it seems clear that if we do indeed exist under the aegis of a cosmic person-making purpose, that purpose must hold us in being beyond this present earthly life.”275

Then Hick raises the question: Can personal identity be conceived as holding over unlimited time? He argues that theoretically "the endlessly prolonged life of finite egos" seems to be possible, while "it is debatable whether this would be a prolonged human life and whether therefore it could serve the purpose of the gradual creation of perfect humanity." 276 The issue of personal identity again seems to involve personal memory, which could not stretch out to infinity. Hick notes, according to Duncan-Jones, that if we understand personal identity in terms of our memory, it could not be prolonged in eternity. ${ }^{277}$ Hick quotes Duncan-Jones’s statement concerning the relationship between personal identity and human memory:

In ordinary life as we know it, only a limited number of acts of memory, with a limited content, can take place in a limited time. As time passes, the number of happenings available to be remembered increases. It follows that if all that is memorable gets remembered equally often, any given memorable event must be remembered more and more rarely as time passes. ... It seems to follow that every event must be remembered more and more readily as time passes. We have then a gradual fading of connections between one part of a person's life and another. In that case it would seem to follow that every person would progressively become more and more unlike a person as we know persons now. Connections would become looser and looser. If we imagine someone in his millionth year, or whatever high number we choose to take, his connections with

\footnotetext{
275 Ibid.

${ }^{276}$ Ibid., 409.

277 Ibid.
} 
the earlier parts of his life will be unimaginably scattered and thin compared with what we are used to. ${ }^{278}$

As Duncan-Jones notes, if we live endlessly, our memory capacity is too full to remember an increasingly long past. Thus I, who am writing these sentences now, will hardly be the same a million years later with completely different remembered experiences.

Hick also presents the idea of personal identity in two different ways: objective and subjective identity. Objective identity, which is also called physical or metaphysical identity, is a view that conceives of a person living forever as one who has "the same body, or the same bodily form, or even the same spiritual substance, throughout eternity."279 Subjective identity is an identity that is viewed from one's own point of view. This is an identity about how we think who we are, and Hick argues against "the notion of the immortal ego as compared with that of a series of lives.”280 Hick argues that a person who was alive a million years ago is hardly considered as the same person anymore due to the "increasing attenuation of memory combined with the increasing inner distance, produced by continuous personal change.”281 Humanity, according to Hick, in the process of soul-making, as sociocultural beings, thus "the ways of becoming and being human are as numerous as man’s cultures.”282 He also contends that the idea

${ }^{278}$ Austin Duncan-Jones, “Man’s Mortality,” Analysis 28, no. 3 (1968), quoted in Hick, Death and Eternal Life, 409.

${ }^{279}$ Hick, Death and Eternal Life, 410.

${ }^{280}$ Ibid., 411.

${ }^{281}$ Ibid.

282 Ibid., 412. 
that man is in a soul-making process seems to be more compatible with the idea of multilives in many worlds than with the idea of immortal ego.

At the end of the section, Hick concludes as follows:

These considerations suggest the likelihood that if the human ego is immortal, or if it persists for a period which multiplies very many times the length of an earthly life, its post-mortem existence occurs in successive sections rather than as one continuous unit. Thus it may be that periodic death (like periodic sleep) divides up an existence which, as finite creatures, we can only live in limited phases. Its recognition of this is, as we have seen, a virtue of the Indian conception of reincarnation. The basic idea does not however have to take the form of repeated rebirths in this world. There is also the possibility of repeated 'rebecomings' in other spheres beyond this world. ${ }^{283}$

Hick finally arrives at his own agenda for pareschatology, which suggests the notion of periodic death and life, a series of different egos, rather than an immortal ego living endlessly throughout eternity, while not ruling it out as a logical impossibility. His suggestion of postmortem existence is in a successive series of existences rather than in one continuous unit.

\section{Hick’s Pareschatology Model: Many Lives in Many Worlds}

According to Hick's model, at physical death the ego ceases to exist in this world, facing the final moment either of entering the ultimate state or, as in the great majority of cases, being unable to face Ultimate Reality. Those who are not able to reach human perfection in this life must "regain consciousness in a post-mortem state." 284 As Bardo Thödol suggests, the immediate postmortem state is "subjective and dream-like.”285 Hick's speculation on the existence right after death even runs like this: "In the first

${ }^{283}$ Ibid., 413-414.

${ }^{284}$ Ibid., 414. Hick argues it is subjective and dream-like according to the insights of the Tibetan Book of the Dead and Western mediumistic communications (ibid.).

${ }^{285}$ Ibid., 416. 
phase of existence after death, as the ego is freed from the constraints of the physical world, this karma ${ }^{286}$ (a gradually formed psychic structure) makes itself known to us in experiences both of wish-fulfillment and of self-judgment.." ${ }^{287}$ Accordingly man is able to get echoes from the next world through some extrasensory perceptions, as Price suggests. Hick considers this state as the bardo world of illusion, which is supposed to last symbolically forty-nine days for judgment. What then is the next state?

Postulating a transition from the bardo world to another embodiment in the next world, Hick is raising a question whether this rebecoming is "a birth as an immature creature which has to grow into its new existence, or an arrival as an already fully formed individual within the new environment." ${ }^{288}$ Two issues are related with this question: whether this life is first or not and what the place of sex is. In regard to the first issue, Hick is inclined to say it is the first life rather than saying that we have lived many lives before. This in turn involves the issue that the next life will be beginning as a matured life rather than starting as a child. He contends that "there need be no presumption that subsequent re-becomings in other worlds will repeat the same pattern." ${ }^{289}$ Concerning the issue of sex in another world, Hick, after a long discussion between Hindu-Buddhist argument and Christian argument, hesitates to conclude what is going to happen for sure

\footnotetext{
${ }^{286}$ Here by "karma" Hick means "what we have become in the course of what we have done" (ibid., 415).

${ }^{287}$ Hick, Death and Eternal Life, 415. This aspect I have discussed already in the section on "The Survival of the Disembodied Mind." Hick notes that Price has developed his theory of psychological survival in two principles: "first, the mind-dependent character of the postmortem world, and second, its formation by the power of human desire" (ibid., 267).
${ }^{288}$ Ibid., 417.
${ }^{289}$ Ibid. 
because it could be only speculation. He says, "these are questions which must remain unanswered in our present life, ${ }^{290}$ because we can scarcely even speculate on it in this world. Accordingly, Hick argues as follows:

We cannot say anything about the next word beyond bardo state except that it will be a real spatio-temporal environment, functioning in accordance with its own laws, within which there will be real personal life-a world with its own concrete character, its own history, its own absorbing and urgent concerns, its own crises, perils, achievements, sacrifices, and its own terminus giving shape and meaning to existence within it. For moral and spiritual growth, as we know it, depends upon interaction with other people within a common environment. ${ }^{291}$

Here Hick's thought is in tension, because he is uncertain about $\operatorname{sex}^{292}$ in the next world while he has his own ideas of the next world or worlds. For instance, even though he has argued for a bardo world, it is only a speculation. The question is how he knows of this bardo state at all, if he does not have access to the world beyond this one. Furthermore, his descriptions concerning the next world—such as a real spatio-temporal environment, law-governed world, and personal life-are able to be described as no more than another speculation or his own mythology.

This series of lives will repeat and the self will undergo another transition, argues Hick, "via another bardo-type experience, into yet another life in yet another world."293 Being unsure of the number of those worlds, Hick suggests that an individual's number

${ }^{290}$ Ibid., 418.

${ }^{291}$ Ibid. This existence in a spatio-temporal environment is identical to Catholicism's intermediate state of purgatory.

${ }^{292}$ Hick discusses two options concerning this issue. If we remain as sexual beings as in this world, children will be born into the next world, which entails the basic picture of the Hindu or Buddhist picture of reincarnation, but from one world to another world. They rise from the dead as the Christian picture shows, the same self would continue, but in a new environment with some fading memories of a previous life in another world. See ibid., 418.

${ }^{293}$ Hick, Death and Eternal Life, 419. 
of "embodiments will presumably depend upon what is needed for him to reach ... the ultimate state, or nirvana.”294 Gaining insights from the Hindu, Buddhist, and Christian pictures, Hick suggests that the number of embodiments will be either almost infinite for those who are worst or only one more for those who are best. Thus, Hick says, "some will require a smaller and others a greater number of embodiments.” ${ }^{295}$ The number of embodiments would all depend on how good or bad they are in this world. And the criteria of goodness and badness that Hick discusses are very vague. It seems that Hick’s idea of good depends on how much a soul "transcends ego-hood and attains the ultimate unitive state.” ${ }^{296}$ But this idea of transcending ego-hood is still too vague to define. We are not sure whether it is internal or external transformation. There are no objective criteria for judging the good or the level of the good.

Appealing to the memory argument that the human being has a limited span of self-apprehension and effective memory, Hick argues that our amount and clearness of memories retained will depend upon whether our lives are many or few. We would remember almost everything if our lives are few, while we should not expect to remember them if they are numerous. And he also claims that "there would be some memory of the immediately past life," which will fade as one is absorbed in the new successive existence. ${ }^{297}$ This does not exclude the possibility of having some memories of many previous lives, which Hick identifies as "memory by some general characteristic
294 Ibid.
295 Ibid.
296 Ibid.
${ }^{297}$ Ibid. 
of each embodiment," 298 similar to an old man who has lived in many houses since childhood but recalls very little detail of them. He also acknowledges that a future self, say, in fifteen hundred years, who does not seem capable of remembering me now in the present, may still be identified as me because of a continuous chain of consciousness that shares "the same personal history." ${ }^{299}$ Regarding the connection of consciousness Hick says, "Each link in the chain will be consciously connected with the one next before it, although it may well be that none of them will be directly conscious, in either perception or memory, of the chain as a whole.” ${ }^{300}$ It seems that he argues for a direct consciousness of the immediately previous life, while having a less direct consciousness of remote previous lives. Here Hick may be mistaken in understanding the capacity of memory in the other worlds as similar to this world. In other words, to Hick it seems that everything in the next world is the same as in this world. Developing his hypothesis on the basis of his other hypotheses, as Hick himself notes and admits, he is "building speculations upon speculations" ${ }^{301}$ rather than evidence-based theories.

In the conclusion of the discussion of “A possible pareschatology,” Hick invites us to get "the broad picture of the human person progressing through ever higher spheres of existence towards a final state.”302 This picture of a human being progressing toward higher states entails Hick's Irenaean two-phased creation of the human being, which is a theological basis of his pluralistic hypothesis. Furthermore, Hick argues that the idea of

\footnotetext{
298 Ibid., 420.

299 Ibid., 421.

${ }^{300}$ Ibid.

${ }^{301}$ Ibid., 420.

302 Ibid., 421.
} 
higher spheres of existence towards human perfection "is consonant with one suggested interpretation of the 'many mansions' of which the Jesus of the Fourth Gospel spoke.”303 Quoting William Temple concerning the many mansions, Hick claims that "the monai ('mansions' or, better, 'resting-places') are ... 'wayside caravanserais—shelters at stages along the road where travelers may rest on their journey." 304 Here again Hick uses a Bible text yet not in its basic and literal sense but in a mythological and nonliteral sense, using an interpretation of a theologian in an idiosyncratic way to support his own view.

\section{A Possible Eschatology}

In his dealings with pareschatology Hick has offered a survey of eschatological views presented both by Eastern and Western religious traditions, mainly Hindu/Buddhist traditions and Christian traditions. Against the general understanding that East and West have conflicting views concerning eschatology, Hick argues that they are "essentially open-ended ... and offer convergent indications, each pointing beyond our present human experience and yet each pointing in the same direction.”305 For instance, different views of postmortem existence such as resurrection, reincarnation, and disembodied mind are all pointing to the general idea of "the next stage of human existence."306 Thus Hick points out that the eschatologies of East and West are not in conflict but at least in a direction of general agreement.

303 Ibid.

${ }^{304}$ William Temple, Readings in St. John's Gospel, vol. 2 (London: Macmillan, 1945), quoted in Hick, Death and Eternal Life, 421-422.

${ }^{305}$ Hick, Death and Eternal Life, 427.

${ }^{306}$ Ibid., 425. 
In his own investigation of the idea of reincarnation, Hick suggests that our existence is not complete in this life but many other lives will be needed for the majority of people. In fact, as Hick notes, if there are many lives to live in the future, we must also assume that we may have lived many times in the past. According to traditional Hindu thought, the incarnated jiva (soul) is eternal and thus has no beginning and end. ${ }^{307}$ According to the basic conception of reincarnation, though this picture has no conflict with the immortality of the soul, it may present, as Hick notes, the "problem of meaninglessness, ${ }^{308}$ that life has no purpose and no ultimate meaning but merely the endless process of becoming. On the contrary, if we believe that the human being is God's creation, thus he has a beginning, argues Hick; "the present life is in fact—as it appears to be-his first life." ${ }^{309}$ In this case, the issue of immortality becomes problematic. If we assume that life has beginning with birth, we also naturally think that it should end at death. Though acknowledging that the birth itself presupposes the death and termination of self, Hick insists that this earthly life is a person's first life on the basis of two facts, one positive and the other negative, neither of which he thinks decisive. The positive fact is that "the individual does seem to be formed ab initio in the womb from which he is born to this present life." 310 The negative fact is that people "do not normally

${ }^{307}$ Ibid., 457. Though Buddhism has slightly different concepts of reincarnation, it has the basic agreement that there are rebirths (or reincarnations) until complete liberation or salvation. Thus it is mere repetition to mention the Buddhist conception of rebirth here.

${ }^{308}$ Ibid.

${ }^{309}$ Ibid. This view is close to the idea of Christianity, which teaches that human beings are God's creation whose life on earth is the first one.

${ }^{310}$ Ibid. 
remember any previous existence." ${ }^{311}$ Hick, in a sense combining these two, presents "the more solid conception of reincarnation" that suggests the idea of "future lives in other worlds."312

According to Christian tradition, Hick notes, a person has only one chance in this earthly life in which he can come to the "saved relationship with God"313 either through his own will or divine grace, and then can have eternal existence in heaven or in hell. Unsatisfied with this traditional view of a heaven and hell scheme, Hick argues that this is unlikely on the basis of two events before and after death. He says:

If salvation in its fullness involves the actual transformation of human character, it is an observable fact that this does not usually take place in the course of our present life. There must, then, be further time beyond death in which the process of perfecting can continue. The traditional scheme is equally unsatisfactory on its post-mortem side. I have argued that the doctrine of hell is morally intolerable; and that in any case the notion of the immortal ego, the finite person continuing endlessly through time, involves profound conceptual difficulties. ${ }^{314}$

Many issues are involved in this statement of Hick's argument against the traditional idea of a heaven-and-hell scheme. First of all, the definition of salvation is mentioned here as "the actual transformation of human character," which is not always observable in this life. If salvation implies human perfection, only a few, if any, religious prodigies will be able to enjoy it. The issue of salvation by faith through grace is almost ignored in Hick's conception of salvation. Second, it should be noted that Hick's argument is based on the traditional understanding of the immortality of soul, which will suffer in eternity if it is damned. As noted earlier, Hick is aware of the fact that the Bible

$$
\begin{aligned}
& { }^{311} \text { Ibid. } \\
& { }^{312} \text { Ibid. } \\
& { }^{313} \text { Ibid., } 455 . \\
& { }^{314} \text { Ibid., } 455-456 .
\end{aligned}
$$


does not teach the immortality of the soul. Rather it shows that death implies the extinction of life (soul). The issues related with these will be discussed more in the following chapter.

However, Hick points out that there is "an important insight behind the traditional Christian insistence that the time of grace, in which we may respond to God, is limited by the boundary of death.”315 He insists that this limitedness of time gives urgency and meaning to our existence in this world, which at the same time does not make the idea of one short life followed by an eternal one necessary. Hick also argues that the same is true with the doctrine of reincarnation, with many lives followed by other lives with many deaths, in which each life and death give a crucial meaning to the entire journey to human perfection. This idea suggests, as Hick notes, that "it is only in incarnate lives on this earth, and not in the many heavens and hells beyond it, that karma can be worked out and progress made towards final liberation.”316

Comparing and critiquing these two basic models of eschatology from East and West, Hick presents his own model which he calls “a third possibility,”317 meaning neither Eastern nor Western. Concerning his own model of eschatology, he says:

I have argued for yet a third possibility, other than eternal-heaven-or-hell or repeated earthly reincarnations, namely that of a series of lives, each bounded by something analogous to birth and death, lived in other worlds in spaces other than that in which we now are. This hypothesis accepts both the insistence upon the need for life to be lived within temporal limits and the conviction that the soul can only make progress in the incarnate state towards its final goal. But it differs from the Western tradition in postulating many lives instead of only one, and from the

\footnotetext{
${ }^{315}$ Ibid., 456.

316 Ibid.

317 Ibid.
} 
eastern tradition in postulating many spheres of incarnate existence instead of only one. $^{318}$

This third possibility that Hick is presenting here is, in a sense, a hybrid version of Eastern and Western ideas of life after death. In short, Hick’s pareschatology is a combination of Hindu/Buddhism and Christianity, yet different from both. As pointed out above, Hick argues that they both agree that human beings are in the process of making progress towards their perfection, while they differ either in the number of existences or in the spheres of existence. By combining these two doctrines, Hick argues that people will live a series of lives in other worlds or spheres until they reach final perfection.

This idea of many lives in many other worlds allows for people to grow spiritually and morally in this world and after. It gives an idea of the same self through many lives growing "towards its final self-transcending perfection." ${ }^{319}$ How does Hick solve the dilemma of inequalities of human birth or life? Evidently the idea of tracing back to past lives does not solve the problem of unfairness of life. Rather, Hick argues that in order to find the solution for the problem of evil, we must look to the future where the real destiny of humanity lies rather than the past. In other words, we need to look at "the final creation of infinite good out of the ambiguities and contradictions of life as we know it” ${ }^{320}$ rather than looking back to the previous lives and what has happened in them. The last question that is raised is "What then is the final state of humanity?" In other words, "What happens when the development of human character towards its self-

${ }^{318}$ Ibid. Hick suggests that there would be a new embodiment after the bardo period. He says, "In Christian terms, of course, such a re-embodiment is what is pointed to by the idea of the resurrection of the dead, and the novelty, from the Christian point of view, of this idea is that it includes a series of resurrections instead of only one" (Hick, Disputed Questions in Theology and the Philosophy of Religion, 195-196).

${ }^{319}$ Hick, Death and Eternal Life, 458.

${ }^{320}$ Ibid. 
transcending perfection is completed?” In answering these questions, Hick suggests that when one achieves perfection, embodiment and time are no longer necessary. ${ }^{321} \mathrm{He}$ adds, "The ultimate state . . is beyond both matter and time, or at least time as we know it."322 In the process of getting closer to higher worlds, people would experience the harmonious mutual love that is a universal life principle, while egoism diminishes. ${ }^{323}$ In this way the individual's series of lives reaches its culmination "in a last life beyond which there is no further embodiment but instead entry into the common Vision of God, or nirvana, or the eternal consciousness of the atman in its relation to Ultimate Reality.” ${ }^{324}$ Hick’s principle of speculation-upon-speculation on eschatology finally ends in his suggestion of "the unity of mankind in a state in which the ego-aspect of individual consciousness has been left behind and the relational aspect has developed into a total community which is one-in-many and many-in-one.” ${ }^{325}$ In order to explain this perfectly harmonious state of humanity, Hick uses the Christian Trinitarian conception of one-inthree and three-in-one. ${ }^{326}$ He applies God's corporate unity to the person's communal life in a perfect harmony with the community of perfected human persons as expressed in the teachings of Jesus and the New Testament. Then Hick concludes: "What Christians call

${ }^{321}$ Ibid., 463.

${ }^{322}$ Ibid. Hick notes that since "objective or clock time is an aspect or dimension of the physical universe," when human consciousness does not relate with one it does not relate with the other (ibid.).

${ }^{323}$ Ibid.

${ }^{324}$ Ibid., 464.

${ }^{325}$ Ibid.

${ }^{326}$ Here Hick shows his own way of using biblical teaching and Christian doctrine to support his own views whenever needed. 
the Mystical Body of Christ within the life of God, and Hindus the universal Atman which we all are, and Mahayana Buddhists the self-transcending unity in the Dharma Body of the Buddha, consists of the wholeness of ultimately perfected humanity beyond the existence of separate egos.”327

\section{Summary and Conclusions}

In the present chapter I have dealt with the main ideas of Hick’s eschatological as well as soteriological model, namely pareschatology. ${ }^{328}$ Pareschatology itself is not posed as a separate issue but rather is dealt with along with other related issues such as anthropology, death, afterlife, etc., within Hick's entire system of pluralism. Therefore, I have started my discussion with how Hick views humanity. Hick’s anthropology is the basis of his further discussion of pareschatology. Though in the course of discussion Hick leaves open the possibility of the mind or nonphysical part of man surviving physical death, as he has developed further in anthropology, he tends to argue that the human being, composed of mind (or soul) and body, is understood as a psycho-physical unity. This line of thinking begins to pave the way to his eschatological model.

In the following section, I have discussed the problem of death in relationship with his agenda of life after death. Hick's main goal of writing Death and Eternal Life is to do a global theology (of death), which could be one of his case studies in doing

${ }^{327}$ Hick, Death and Eternal Life, 464.

${ }^{328}$ As I have discussed earlier, Hick’s eschatological model, that is, pareschatology is not a theological issue that is separated from his entire theological system. Though Hick's pareschatology is termed a type of eschatology, in reality it is more closely related with soteriology. Thus, pareschatology must not solely be seen as a type of eschatological model but also a soteriological model, because it concerns a person's ultimate salvation after a long process of soul-making throughout various afterlives. 
religious pluralism. Death, unlike the traditional Christian view which sees it as the moment of eternal destiny, is seen as a moment to look for the further chance in the journey of soul-making process. Thus death is not a disastrous or unnatural experience, but it is understood as "a necessary part”329 of man's journey towards the likeness of God, as Ireanaean theology suggests. According to Hick, death is to be understood not as a moment of eternal destiny but as a moment of transition to a higher form of existence.

Hick's understanding of death naturally leads us to the discussion of afterlife, which is dealt with in the following section. The bottom line is, as Hick admits, that the afterlife is beyond our knowledge because of its inaccessibility, at least in an empirical point of view. However, he presents the rational and moral argument that it is not morally realistic to have a brief earthly life followed by a divine judgment of either eternal heaven or hell. ${ }^{330}$ He argues that it would be only fair if there is afterlife or afterlives in which many injustices or unfairnesses are remedied, which entails a classical problem of theodicy. This line of thinking led Hick to postulate the possibility of many lives after death, which is one of the main theses of pareschatology.

Here, I have arrived at the main issue of this dissertation. It must be noted that, as the title of the section suggests, pareschatology is a natural product of Hick's pluralistic hypothesis. Hick’s eschatological model not only deals with eschatology but also with 166.

${ }^{329}$ Robison, Life after Death? Christian Interpretation of Personal Eschatology,

${ }^{330}$ See Richard Rice, review of Death and Eternal Life, by John Hick, Andrews University Seminary Studies 17, no 2 (Aut. 1979): 216-218. As Richard Rice says, "Hick's own argument for life after death takes the form of a response to the problem of suffering. If human existence is meaningful, he maintains, then suffering requires moral justification. However, such justification is adequate only if the individual himself participates in the ultimate good to which his suffering contributes, rather than, say, merely passing on the benefits to subsequent generations. The moral justification of suffering thus requires the individual survival of bodily death” (ibid.). 
pareschatology which, as Hick claims, deals with the human state between death and the final salvation. This can be seen as eschatology from a Christian perspective, yet he prefers to call it pareschatology, maybe because he wants to be inclusive towards other models such as Hindu/Buddhist alternatives.

The reasoning behind Hick’s preference of doing pareschatology rather than eschatology is that it has more immediate phases which may bear "sufficient analogy to our present state or some of our speculations about it."331 The idea that pareschatology deals with events less remote and at the same time more immediate does not guarantee that we may be able to know them more easily. Furthermore, Hick's claim that we have easier access in pareschatology than eschatology is in conflict with his own statement made earlier. Since we have no knowledge beyond death, Hick's content of what he calls pareschatology is still beyond our present cognition.

After defining the term "pareschatology,” I have dealt with three major issues that Hick includes in his discussion of pareschatology: the survival of the disembodied mind, the resurrection of the person, and the reincarnation. Hick uses Price's psychological survival hypothesis to show some kind of survival of death. Unlike the idea of Price who sees the next world as something different from the present one, which is almost a solipsistic world where souls are living in a dream-like world of mental images, Hick contends that "the next world would be similar in nature to this world." 332 Hick concludes that as "we try to conceive of the post-mortem existence of the disembodied 132.

${ }^{331}$ Hick, Death and Eternal Life, 22.

${ }^{332}$ Schmitt, Death and After-Life in the Theologies of Karl Barth and John Hick, 
mind we find that this is not after all truly disembodied." ${ }^{333}$ Therefore, according to him, though not being clear as to what that state exactly is, the survival of the disembodied mind is not something completely odd but a special form of embodied postmortem existence. By not totally denying the possibility of disembodied survival, ${ }^{334}$ Hick opens a possibility to discuss more about human survival in terms of different forms.

Then as I have discussed, Hick draws our attention to the Christian conception of what he calls the re-creation of the psycho-physical person. He introduces his own "replica" theory in the Bible, maybe to present resurrection in a more intelligible way for postmodern minds. This putative "replica" does not simultaneously exist with its original, or else it is not a "replica" at all but only a replica. Hick tries to show that resurrection is possible with the idea of "replica" that he presents. All he tries to accomplish, though admitting that it is a speculation, is that it is conceivable that resurrection is "the divine re-creation of the individual after his earthly death as a total psycho-physical 'replica' in another place." 335 However, though functionally the "replica" can be treated as me in the premortem existence, it is doubtful that this "replica" is really me from my own perspective. Yates argues that Hick’s "replica” is a mere “replica, an imitation.”336

Then I have dealt with Hick’s alternative from Eastern religions, reincarnation. The doctrine of reincarnation is getting more and more attention in Western society as interaction of cultures and religions between East and West increases. Hick's main reason

${ }^{333}$ Hick, Death and Eternal Life, 276.

${ }^{334}$ As noted, Hick eventually leans toward the idea of embodied existence rather than disembodied survival after bodily death. However, as a pluralist he, instead of rejecting the idea at once, gets the basic insight (the survival after death) out of it.

${ }^{335}$ Hick, Death and Eternal Life, 293.

${ }^{336}$ Yates, "Survival as Replication,” 6. 
for considering the Indian version of eschatology is that it may answer the vexing problem of the unfairness of life, which appears to be in contradiction with the notion of a good and powerful God. Hick’s suggested solution to inequality or evil in human existence is made through his appeal to the God of love, ${ }^{337}$ which is extensively discussed in his book, Evil and the God of Love. The basis of Hick's search for a new model of eschatology is his Irenaean type of theodicy that a good and powerful God is not in contradiction with the existence of evil, which is a necessary part of creation. Accordingly, looking for some insights from Eastern religions, Hick argues, while Western people have difficulty answering human inequalities of life, Hinduism and Buddhism may offer a better alternative to answering these questions. According to the reincarnation doctrine, present conditions of our life are "a direct consequence of our previous lives.”338 By drawing our attention to the previous lives, the doctrine of reincarnation answers the questions of physical and social inequalities of human life. Again in the discussion of reincarnation, the issue of the identity of a certain person is one of the main concerns. After discussing three strands of continuity—memory, bodily continuity, and the psychological continuity—which may provide for personal identity, Hick dismisses the first two on the basis of the fact that we bear virtually no memories of past lives and any change of sex, race, or turning into other species. Psychological continuity, though being able to solve the problem of sexual, racial, and special changes

${ }^{337}$ Hick's appeal to "the God of love" for theodical issues is replaced by a "cosmic optimism"- "an anticipation in faith that the limitlessly good possibilities of existence will finally be realized"-in his Kantian writings since the mid-80s (Hick, $A n$ Interpretation of Religion, 57). This is a sign that Hick is a pluralist from a philosophical point of view who tries to remove any theistic color in his writings while retaining the same idea.

${ }^{338}$ Hick, Death and Eternal Life, 169. 
between existences, is too vague to prove reincarnation, because there are so many people with the almost identical personality traits. Thus, going back to the issue of memory, Hick argues for the existence of an unconscious thread of memory connecting existences which will "remain latent until a final moment of total recall as the reincarnating soul at last attains to enlightenment.”339 I have discussed Hick’s view of another version of reincarnation. Buddhism suggests that, though nama-rupa (embodied existence) does not survive, there will be another form of existence called "a formation of non-conscious psychic elements" 340 _ linga sharira (psychic factor) — after bodily death. By presenting the rebirth in different types of worlds-the kama-worlds (sense worlds), the rupa-worlds (worlds of visible form though not sense), and the arupa-worlds (incorporeal worlds of thought) ${ }^{341}$ —Hick contends that the rebirth or rebecoming may not necessarily occur in this earthly life, which opens the possibility of reincarnation in other worlds. Moreover, I have included Hick’s discussion of reincarnation in relationship with Christianity. Using four arguments that are originally employed by Christians to argue against reincarnation, Hick reversed them to support the possibility of reincarnation doctrine in Christianity. At least, he seems to claim that the reincarnation doctrine is not completely incompatible with Christian gospel. And again regarding the issue of memory, as Hick notes, that is thought to be a link between existences but cannot provide emperical evidence for confirmation or disconfirmation.

At the final stage I have dealt with Hick’s conclusion of the work, Death and Eternal Life. In Hick's discussion of pareschatology, two issues are to be borne in mind.

\footnotetext{
339 Ibid., 308.

${ }^{340}$ Ibid., 344.

${ }^{341}$ Ibid., 346.
} 
First of all, the issue of identity is crucial, because without a self-conscious ego we are not able to say that the resurrected or reincarnated person is the same person. Second, the fact that there are only a few who seem to reach human perfection or salvation, necessitates the state of pareschatolgy which may give equitable opportunities to everyone. In order to reach this objective, Hick presents the picture of the bardo world, which shows that the soul goes through three stages ${ }^{342}$ before going back to the cycle of birth and death. This idea of the bardo world gives some kind of process of soul-making. Also according to Western spiritualism, there are seven planes of existence before the soul is finally one with God, which implies the transition or movement from one level to another, Hick calls “a movement towards a goal.”343 Then I have included Hick’s discussion on the issue of the immortal ego. Based on Duncan-Jones's discussion about the relationship between personal identity and memory, Hick notes that if we live forever, we cannot remember an increasingly long past because of our limited memory capacity. The human being in the process of soul-making throughout eternity is also a sociocultural being, who is being formed not only by his memories but also his own cultures that he is born into. Thus, Hick argues that there will be a series of different egos through periodic death and life, rather than an immortal ego living forever. According to him a person will experience the process of soul-making through a successive series of existences rather than in one continuous unity.

${ }^{342}$ As I mentioned earlier, three stages that the soul goes through are as follows: (1) The soul surrounded by blinding light has a chance to immediate salvation, but only few who are ready will have this chance; (2) The soul is exposed to good and evil powers; (3) The soul goes back to the cycle of birth and death again. See Hick, Death and Eternal Life, 401-404.

${ }^{343}$ Ibid., 407. 
Basically, combining eschatologies of East (reincarnation) and West (heaven or hell), Hick finally suggests his idea of “many lives in many worlds” as his solution for the conflicting views of humanity’s final state, namely eschatologies. Interestingly, Hick employs these two ideas to formulate his own model, yet disregards the elements that are in conflict. Hick's thesis of a global theology of death pushes him to a theology that may include all possible forms of eschatology, and then ironically disregards many of their elements by presenting his own. As a result of combining eschatological models of East and West, Hick presents the broad picture of human existence through higher forms of life towards a final state. By adopting the Irenaean anthrolopology of the double creation of humanity, Hick has applied an evolutionary principle of humanity evolving from the lower to the higher and even to the state of human perfection in his pareschatology. Interestingly, Hick even tries to connect the idea of higher spheres of existence towards human perfection with "many mansions" in the Gospel of John, which shows his use of Bible texts in a mythological and nonliteral sense.

In conclusion, after many lives in many worlds, argues Hick, people will eventually arrive at the final state of human perfection. In this state, the individual's series of lives reaches its culmination "in a last life beyond which there is no further embodiment but instead entry into the common Vision of God, or nirvana, or the eternal consciousness of the atman in its relation to Ultimate Reality.”344 At this final moment of Hick’s pareschatological stage, man’s self-centeredness is replaced by realitycenteredness. Hick understands this eschatological state as "a total community which is one-in-many and many-in-one.” ${ }^{345}$ However, this egoless community that Hick calls "the
${ }^{344}$ Ibid., 464.
345 Ibid. 
unity of mankind”346 is an intriguing concept that can hardly be viewed as a desirable experience or existence of human beings. Now, this chapter, along with previous ones, has prepared us to turn our eyes to the main part of the dissertation, where I present a critical evaluation of Hick’s religious pluralism in light of his pareschatology, which will follow in the next chapter.

${ }^{346}$ Ibid. 


\title{
CHAPTER V
}

\section{CRITICAL EVALUTATION OF HICK’S PLURALISM}

\author{
IN LIGHT OF PARESCHATOLOGY
}

\section{Introduction}

Whereas in the previous chapters I have focused on factual descriptions of Hick's life, his philosophy of religious pluralism, and particularly his pareschatology, in this chapter I evaluate his pareschatology in light of two basic theories of truth, namely, the correspondence theory of truth and the coherence theory of truth ${ }^{1}$ that Hick himself employs in his discussion of religious pluralism.

The criticisms presented in this chapter are informed in light of Hick’s Kantian shift as indicated in his writings which contain, according to Hick, "the more fully

${ }^{1}$ I employ these two as Hick does in his arguments for his theory of world religions. They are the two most generally accepted theories of truth to verify the validity of an argument. See Peter A. Angeles, “Coherence Theory of Truth,” Dictionary of Philosophy, ed. Peter A. Angeles (New York: Barnes \& Noble Books, 1981), 297-298; Peter A. Angeles, “Correspondence Theory of Truth,” Dictionary of Philosophy, ed. Peter A. Angeles (New York: Barnes \& Noble Books, 1981), 298; A. Cornelius Benjamin, "Coherence Theory of Truth,” Dictionary of Philosophy, ed. Dagobert D. Runes (Savage, MD: Littlefield, Adams Quality Paperbacks, 1983), 74; Max Black, “Correspondence Theory of Truth,” Dictionary of Philosophy, ed. Dagobert D. Runes (Savage, MD: Littlefield, Adams Quality Paperbacks, 1983); Simon Blackburn, "Coherence Theory of Truth,” The Oxford Dictionary of Philosophy, ed. Simon Blackburn (New York: Oxford University Press, 1996), 67; Simon Blackburn, “Correspondence Theory of Truth,” The Oxford Dictionary of Philosophy, ed. Simon Blackburn (New York: Oxford University Press, 1996); Antony Flew, "Coherence Theory of Truth,” A Dictionary of Philosophy, ed. Antony Flew (New York: St. Martin’s, 1984), 66; Antony Flew, “Correspondence Theory of Truth,” A Dictionary of Philosophy, ed. Antony Flew (New York: St. Martin’s, 1984), 76-77; Horwich, “Truth,” 929-931. 
developed pluralistic hypothesis." ${ }^{2}$ These writings include titles such as, "Straightening the Record” (1990), An Interpretation of Religions: Human Responses to the Transcendent (1989), A Christian Theology of Religions: The Rainbow of Faiths (1993), and Who or What Is God? And Other Investigations (2008). Based upon his Kantian shift, Hick seeks more explicitely to characterize religious discourse as mythological. For example, Hick contends that "we speak mythologically about the noumenal Real by speaking literally or analogically about its phenomenal manifestations." ${ }^{3}$ Regarding his theodicy, Hick claims that "such a theodicy is mythological in the sense that the language in which it speaks about the Real, as a personal being carrying out intentions through time, cannot apply to the ultimate transcendent Reality in itself." ${ }^{4}$ However, Hick considers Irenaean theodicy in which humans are created in the image and likeness of God as "a true myth" in the sense that "such a theodicy nevertheless constitutes a true myth in so far as the practical attitudes which it tends to evoke amid the evils of human life are appropriate to our present existence in relation to the Real..”5 Moreover, Hick says, "this theodicy may be—and indeed I believe it is—mythologically true. That is to say, it may be the case that seeking to bring good and mutual caring in face of disasters, and by cherishing an ultimate hope beyond this life, is appropriate to the actual character of our situation in the presence of the Real.” ${ }^{6}$ Thus, Hick’s pareschatology which is based upon his Irenaean theodicy will be evaluated in this perspective.

\footnotetext{
${ }^{2}$ Hick, “Straightening the Record: Some Response to Critics,” 194.

${ }^{3}$ Hick, An Interpretation of Religion: Human Responses to the Transcendent, 351.

${ }^{4}$ Ibid., 359.

${ }^{5}$ Ibid., 359-360

${ }^{6}$ Ibid., 360.
} 


\section{Pareschatology Criticisized in Light of Correspondence Theory}

As other serious thinkers and philosophers do, Hick tries to be as strong as possible in his arguments for religious pluralism, particularly his pareschatology. The most fundamental theory of truth that he employs is no doubt the correspondence theory of truth on which he builds his arguments for the theory of world religions.

\section{Correspondence Theory of Truth}

The correspondence theory of truth is perhaps the most well-known and widely accepted theory of truth, which is often summed up, as Kirkham says, "with the slogan 'truth is correspondent with the facts' or 'truth is agreement with reality.,," A wellknown formula of this theory is given by Aristotle: “To say that [either] that which is is not or that which is not is, is a falsehood; and to say that that which is is and that which is not is not, is true.”8 Thus, this theory is considered one of the most basic tools for testing the validity of statements. It seems that most philosophers, including Hick, use this theory of truth to defend their arguments.

Though there are generally two types of the correspondence theory of truth“correspondence as correlation, and correspondence as congruence" ${ }^{9}$ — the situation may

${ }^{7}$ Richard L. Kirkham, “Correspondence Theory of Truth,” Routledge Encyclopedia of Philosophy, ed. Edward Graig (New York: Routhledge, 1998), 472. See Bertrand Russell, The Problems of Philosophy, Home University Library of Modern Knowledge, vol. 35 (New York: Henry Holt and Company, n.d.), 186-203.

${ }^{8}$ Kirkham, "Correspondence Theory of Truth,” 473.

${ }^{9}$ Ibid. The former view claims that "every truth bearer (proposition, sentence, belief, and so on) is correlated to a possible fact. If the possible fact to which a given truth bearer is correlated actually obtains, the truth bearer is true; otherwise it is false" (ibid.). The latter view claims that "truth bearers and the possible facts to which they correspond have parallel structures” (ibid.). 
be summarized as Kirkham does, “A truth bearer is true if and only if it corresponds to a state of affairs and that state of affairs obtains."10

The term "correspondence theory of truth" has been popularized through the influence of Bertrand Russell, who formulates the view that truth consists in some form of correspondence between statement and fact. ${ }^{11}$ Bertrand Russell's own description clearly sums up the essence of the theory as follows:

It is perfectly evident as soon as you think of it, that a proposition is not a name for a fact, from the mere circumstance that there are two propositions corresponding to each fact. Suppose it is a fact that Socrates is dead. You have two propositions: "Socrates is dead" and "Socrates is not dead." And those two propositions corresponding to the same fact, there is one fact in the world, that which makes one true and one false. . . . There are two different relations . . . that a proposition can have to a fact: the one the relation that you may call being true to the fact, and the other being false to the fact. ${ }^{12}$

In other words, two contradictory claims about one fact cannot both be true at the same time because they do not both correspond to the fact. The basis of evaluation depends on true correspondence between a statement about a fact and the actual state of the fact. ${ }^{13}$

${ }^{10}$ Ibid.

${ }^{11}$ Russell, The Problems of Philosophy, 190, 202-203.

${ }^{12}$ Bertrand Russell, Logic and Knowledge (New York: Macmillan, 1964), 187.

13 This view is also closely connected with what is known as the law of noncontradiction, which claims that contradictory statements cannot both at the same time be true. For instance, the two propositions A is B and A is non-B cannot both be true at the same time because they are mutually exclusive. If one is true, the other is not. Whatever statement we may want to make, in a sense, we base our argument on the basis of the correspondence theory of truth. According to Bertrand Russell, three traditional laws of thought - (1) the law of identity: "Whatever is, is"; (2) the law of [non]contradiction: "Nothing can both be and not be"; (3) The law of excluded middle: "Everything can both either be or not be"-form the logical bases of the correspondence theory of truth (Russell, The Problems of Philosophy, 113). 
Pareschatology and Criticisms from Correspondence Theory

In this section, I will make a critical evaluation of Hick’s pareschatology from the viewpoint of correspondence theory of truth. In so doing, I will include four major issues which are critical to and inform his concept of pareschatology: (1) The Real, (2) anthropology, (3) death, and (4) afterlife.

\section{One: The Real, Pareschatology and Correspondence Theory}

As noted earlier, Hick's theory of world religions, including pareschatology, is first built upon his pre-Kantian notion of $\operatorname{God}^{14}$ who is at the center of the universe of faiths, and later upon his Kantian understanding of the Real as it is in itself that is at the center of its various manifestations. According to the later or Kantian Hick, the "Real an sich" is beyond the realm of human cognitive ability ${ }^{15}$ in the sense that "things known are in the knower according to the mode of the knower."16 Thus, Hick argues, "that infinite reality as it is in itself cannot be represented in our finite human terms.” ${ }^{17}$ Hick, on the basis of his adoption of the Kantian insight between noumenon and phenomenon, has arrived at the Kantian revolution, a dichotomy between noumenon and phenomenon-as Eddy notes, "a synthesis that forms the foundation for his response to the problem of

${ }^{14}$ Hick's early pre-Kantian God is replaced by his tradition-neutral term the Real in his later writings, yet it does not indicate that he has canceled the idea of God but shows that he broadens the idea of God in light of his Kantian shift. 249.

${ }^{15}$ Hick, An Interpretation of Religion: Human Responses to the Transcendent,

${ }^{16}$ Hick, Who or What Is God? And Other Investigations,10.

${ }^{17}$ Ibid., 12. 
conflicting conceptions” about the Real. ${ }^{18}$ Hick insists that "we postulate the Real an sich as the ultimate ground of the intentional objects of the different forms of religious thought-and-experience," ${ }^{19}$ without which his theory of religious pluralism is impossible. Though hesitating to spell out any concrete idea of the Real, whether it is "one or many, person or thing, conscious or unconscious, purposive or nonpurposive, substance or process, good or evil, loving or hating., ${ }^{20}$ Hick centers his theory of world religions including pareschatology on the notion of this central reality, the Real. Thus, Hick's pareschatology inevitably involves openness to the Real conceived in this fashion. ${ }^{21}$

I offer two criticisms regarding pareschatology in relationship to the Real in this section. The first criticism has to do with Hick's arguments concerning pareschatology in relation to his notion of the Real. If we have no definite knowledge of the Real an sich, whether it is good or evil, purposive or nonpurposive, one or many, there seems to be no incentive to seek a salvific relationship that is claimed to occur in this life or in a pareschatological life through our openness to the Real. In other words, as Rose notes, "If the Real an sich, as Hick contends, is beyond speech, knowledge, and experience, then

\footnotetext{
${ }^{18}$ Eddy, "Religious Pluralism and the Divine: Another Look at John Hick’s NeoKantian Proposal,” 468. 350.

${ }^{19}$ Hick, An Interpretation of Religion: Human Responses to the Transcendent,

${ }^{20}$ Ibid.

${ }^{21}$ Alan F. Segal sums up the essence of Hick's theocentric model of world religions as follows: "He [Hick] accepted the truths of every religion as they oriented the believer towards reality. He further suggested that no religion was inherently superior to another but that all somehow were constructed manifestations of the real” (Alan F. Segal, Life after Death: A History of the Afterlife in the Religions of the West [New York: Doubleday, 2004], 724).
} 
one has no choice but to remain silent about it.”22 If we admit that there is no possible knowledge about the Real, it seems rather meaningless to talk about human experience with the Real which Hick wishes to do. Whatever the speculations we make about the intermediate state, there seems to be no way of establishing here and now that our assumed improving relationships even here and now correspond with the Real.

A second criticism concerns Hick’s attempt to move beyond his earlier theocentrism. Hick, on the one hand and working from a Christian background, does not want to be blinded by Christianity and does not want to call the Real the God of the Bible. He must choose a term that is not biased by any religious tradition and that can satisfy any world religion. ${ }^{23}$ Hick’s attitude leads him, particularly in his Kantian orientation in which he distinguishes between nounmenon and phenonomenon, to adopt the language of “an ultimate transcendent reality, the Real,”24 which has no theistic color in it. However, on the other hand, whatever terminology he may adapt for the Real, it seems that Hick has a tendency to describe the Real with theistic elements by connecting the word “divine” with the theistically colored word "God" in his most recent book, Who or What Is God? And Other Investigations (2008). For example, he refers to "the ultimate light of the universal divine presence" which seems to imply a theistic presence. ${ }^{25}$ This does not

\footnotetext{
${ }^{22}$ Rose, "Knowing the Real: John Hick on the Cognitivity of Religions and Religious Pluralism,” 12.

${ }^{23}$ Hick, A Christian Theology of Religions: The Rainbow of Faiths, 23.

${ }^{24}$ Hick, Who or What Is God? And Other Interpretations, 11.

${ }^{25}$ Ibid., 12. Other references to the divine in the same context include the following: "the ultimate divine reality," "the divine noumenon," "the ultimate light of the universal divine presence,” and “the infinite divine reality” (ibid., 9, 11, 12).
} 
seem to correspond with Hick's own attempt to describe the Real in nontheistic and impersonal terms. $^{26}$

\section{Two: Anthropology, Pareschatology and Correspondence Theory}

Perceiving man as a psycho-physical unity ${ }^{27}$ in which two inseparable partsmind and body_-interact with each other, Hick begins his discussion from the biblical account of the first two chapters of Genesis and combines it with the modern scientific viewpoint. Though coming from a Christian background as a descendent of liberalism which insists that "there is no conflict between science and religion,"28 Hick must do his anthropology more on the basis of science than religion. Whenever science and religion clash with each other, Hick is ready to give the priority to science and is willing to reinterpret the account of the Bible concerning the nature of human beings. As a result, though using biblical accounts for understanding the human being, he uses the lens of science to interpret them. For instance, as for Scripture's description of man's creation as being made out of dust from the ground, Hick reinterprets the creative process of the human being as emerging "from dust to the immensely complex religious and valuing human animal.”29 However, Hick’s man is neither the man of the Bible classically

${ }^{26}$ See Hick, An Interpretation of Religion: Human Responses to the Transcendent, 249; idem, A Christian Theology of Religions: The Rainbow of Faiths, 47.

${ }^{27}$ Hick's understanding of the human being as a psycho-physical unity is close to the biblical picture of man as a holistic being, though sometimes seen as spirit, soul, and body.

${ }^{28}$ Pierard, “Theological Liberalism,” 683.

${ }^{29}$ Hick, Death and Eternal Life, 47. Hick also views man as God's creature, but with an immature condition, who needs to go through the process of soul-making as Irenaean anthropology suggests. 
interpreted who was created on the sixth day of creation week by God's miraculous power, nor the man of evolution who comes to existence through a wholly natural process of evolution without any supernatural power. ${ }^{30}$ Hick's man is a being who is ever in the process of soul-making in relation to the Real, ${ }^{31}$ as Hick's evolutionary principle of pareschatology suggests. This means that while Hick seems to embrace a wholly naturalistic ideological evolutionary theory of origins, his own account of human origins does not correspond to a wholly naturalistically interpreted biological evolutionary theory.

In regard to the notion of the human soul, Hick claims that "the soul is the locus of our personal and moral freedom.” ${ }^{32}$ Then, we should understand the soul with certain basic moral and religious characteristics with which we are born, besides heredity and environments, which make one person different from another person in basic dispositions. However, this does not mean that Hick considers the soul as "the name of a spiritual substance or entity.”33 That is to say, Hick does not claim that the soul is some kind of

30 Today, though many scholars believe that the creation in Genesis did not take place within six days, some scholars still believe that they are literal and historical days. In regard to the days of Gen 1, Gerhard F. Hasel argues that "both liberal and nonliberal scholars have concluded that the word 'day' (Hebrew yôm) in Genesis 1 must be understood in a literal sense" (Gerhard F. Hasel, "The 'Days' of Creation in Genesis 1: Literal 'Days' or Figurative 'Periods/Epochs' of Time?,” in Creation, Catasrophe, and Calvary, ed. John T. Baldwin [Hagerstown, MD: Review and Herald, 2000], 53). See also General Conference of Seventh-day Adventists Ministrial Association, Seventh-Day Adventists Believe . . . : A Biblical Exposition of 27 Fundamental Doctrines (Hagerstown, MD: Review and Herald, 1988), 71. Thus, macroevolution that is based on scientific materialism and creation that is based on a literal and historical reading of Genesis, as Ian G. Barbour rightly notes, are such that "a person must choose between them" (Ian G. Barbour, When Science Meets Religion [New York: HarperCollins, 2000], 11).

${ }^{31}$ Hick's soul-making process is a salvific transformation of being that is taking place in this life and after when a person is open to the Real.

\footnotetext{
${ }^{32}$ Hick, Death and Eternal Life, 42.

33 Ibid., 45.
} 
separable entity. Later, he suggests that the word soul can be understood "as an indicator of value, ${ }^{34}$ which speaks of the entire human being as a soul rather than part of the the human being. However, Hick's understanding, on the one hand, that the human mind could possibly survive bodily death in disembodied form ${ }^{35}$ and, on the other hand, his claim that humans are in some sense inseparable psycho-physical unities ${ }^{36}$ both in this world and in other worlds are two mutually exclusive claims that cannot at the same time correspond to reality. ${ }^{37}$

\section{Three: Death, Pareschatology and Correspondence Theory}

Acknowledging the universality of death, Hick tries to develop a new approach in theology called "a global theology of death,” which attempts to provide an interpretation that reconciles different views and understandings of religious experience. Perceiving apparent differences among religions concerning death, Hick argues that the differences are not religiously significant insofar as they provide salvific transformation within a religious community. In other words, to Hick, various theologies seem less important than salvation. ${ }^{38}$

${ }^{34}$ Ibid. This understanding of a human being as soul is mythological rather than literal according to Hick (ibid., 39).

35 Ibid., 112. See also ibid., 265-277.

${ }^{36}$ Ibid., 278, 294.

${ }^{37}$ This issue can be criticized through a coherence theory of truth, though Hick may argue that it is simply a revision or broadening of his previous view.

${ }^{38}$ Heim, “The Pluralistic Hypothesis, Realism, and Post-Eschatology,” 211. 
Articulating the global theology of death from the perspective of human origin, Hick prefers the Irenaean view ${ }^{39}$ of man to the Augustinian view, which inevitably leads him to think that death is not a negative reality occurring as the result of the fall. Death is not only an inevitable passage but a necessary step towards the transition from one world to another and helps one to grow in God's likeness, as Hick's evolutionary principle of pareschatology suggests. To Hick, death is seen not as a moment of eternal judgment but as a moment of transition to a higher level of existence. This view of death, which Hick claims to be the Irenaean understanding of death, ${ }^{40}$ is not compatible with the Augustinian notion of death, which considers death as a direct result of the fall and which will finally be overcome at the second coming of Jesus Christ. ${ }^{41}$ From a correspondence point of view we can note that though providing a very optimistic and positive notion of death inspired by Irenaean anthropology, in the real world there seems to be no corresponding fact that the real character of death is like that which is described by Hick. In this respect, correspondence theory uncovers a difficulty of correspondence verification in Hick's theory of death and pareschatology.

${ }^{39}$ George Panthanmackel notes: "Instead of the Augustinian doctrine that God created man perfect, but because of his sin, he became imperfect and sinful, Irenaeus holds that God created man imperfect and immature, but would be brought to perfection through growth and development, intended for him by his maker" (Panthanmackel, "Problem of Evil: Hick’s Sublimation of Plantinga," 258).

${ }^{40}$ According to Roger A. Badham, the same view is shared by Schleiermacher who offers "a fruitful way beyond the Augustinian theory of original sin" (Roger A. Badham, "Redeeming the Fall: Hick’s Schleiermacher Versus Niebuhr’s Kierkegaard,” The Journal of Religion 78, no. 4 [Oct. 1998]: 547).

${ }^{41}$ For some Scripture passages reflecting on the classic Christian understanding of death see Gen 3:19; 1 Cor 15:51-54; 1 Thess 4:16, etc. 


\section{Four: Afterlife, Pareschatology and Correspondence Theory}

Though admitting that there is no sure evidence of life after death, ${ }^{42}$ Hick tries to present some empirical evidences of afterlife such as parapsychology and burial practices of ancient people. ${ }^{43}$ Hick acknowledges that these cannot be proof for the existence of an afterlife, yet he argues "the fact that we cannot as of now establish life after death by empirical evidence does not mean that there is no life after death.”44

Another interesting argument Hick presents to ground his reasons in support of an afterlife is taken from rational and moral perspectives. Hick argues, "The objections to the doctrine of eternal torment which . . . now seem so strong are well known: for a conscious creature to undergo physical and mental torture through unending time ... is horrible and disturbing beyond words; and the thought of such torment being deliberately inflicted by divine decree is totally incompatible with the idea of God as infinite love.”45 Hick in effect shows that a judgment of eternal conscious torment following a brief earthly life is simply unfair. Hick has now suggested that after death humans are not suffering in hell, but he also claims that they are not extinct. ${ }^{46}$ This leads to Hick's theory of afterlife noted below.

Starting from the appeal to unfairness of life and the rejection of hell, Hick now argues for the existence of afterlife on the basis of the purpose of human existence. Hick

\footnotetext{
${ }^{42}$ Hick, Disputed Questions in Theology and the Philosophy of Religion, 187.

${ }^{43}$ Ibid.

${ }^{44}$ Ibid.

${ }^{45}$ Hick, Death and Eternal Life, 200-201.

${ }^{46}$ Ibid., 263-396.
} 
says, "The basic thought here is that one life-span is not enough for the transformation of human beings from the self-centredness of our natural state to the unity or community with the divine reality which is the ultimate aim of human existence." ${ }^{47}$ Thus, on answering a Christian question, as La Due asks, “How could divine justice ever demand as a punishment for finite human sins an infinite penalty of eternal torture?" ${ }^{48}$ Hick invokes “a series of lives, each bounded by something analogous to birth and death, lived in other worlds in spaces other than that in which we now are." 49

From a purely moral and rational point of view, Hick's view seems to be a more attractive alternative than the idea of eternal torment in hell. However, Hick's speculation on afterlife has no corresponding facts with which it can be compared, since afterlife is outside of our knowledge. Due to human limitation, correspondence theory underscores a verification limitation in Hick’s pareschatological account of life after death.

Another correspondence criticism concerns Hick's notion that this earthly life is too short for most people to experience moral and spiritual growth. In other words, Hick’s reasoning implies that if people could live long enough on earth, their life will become better and better morally and spiritually up to the point of perfection. However this claim does not seem to correspond with observable reality because a person's longevity does not necessarily improve his moral and spiritual life. ${ }^{50}$ On the contrary, for

${ }^{47}$ Hick, Disputed Questions in Theology and the Philosophy of Religion, 189.

${ }^{48}$ La Due, The Trinity Guide to Eschatology, 122.

${ }^{49}$ Hick, Death and Eternal Life, 456.

${ }^{50}$ Hick provides no answer to why "the process of human soul-making takes as long as it does, instead of half or a quarter or a hundredth as long. This is a question which we cannot answer. . . . We do not know why the time-scale of God's dealings with us is as it is" (Hick, Death and Eternal Life, 259). 
many people, longevity may lead their life in the opposite way and their moral life may deteriorate. ${ }^{51}$ For example, the twentieth century did not turn out to be the Christian century as expected. Two world wars cut short the hope of human development. Thus, if Hick acknowledges that some people do not progress but "on the contrary regress” in this life, ${ }^{52}$ and if he assumes that the strength of the Real's salvific influence is the same in this life as it is in the lives to come, on what compelling ground does he claim that those who "regress" in this life will be healed in their next lives up to the point of final perfection?

\section{Pareschatology Critisized in Light of Coherence Theory}

Hick also applies the coherence theory of truth in his arguments. ${ }^{53}$ Hick tries to be as coherent as possible in his system of religious pluralism, because without having internal consistency, his theory will not stand firm but collapse.

\section{Coherence Theory of Truth}

The coherence theory of truth is one of the most well-known traditional theories of truth along with the correspondence theory. Whereas the correspondence theory holds that a statement is true when it corresponds with the fact, the coherence theory holds that

${ }^{51}$ For instance, on a literal reading of Gen 6-9, many antediluvian people lived at least ten or more times longer than we now do, but instead of getting better, they became spiritually worse and worse, causing God to send the flood of judgment.

${ }^{52}$ Hick, Death and Eternal Life, 155.

53 To Hick the issue of coherence is crucial, because it is one of the philosophical foundations of his theological arguments. Thus, as Swinburne notes, "Hick seeks to construct a picture of the after-life which draws on what is most coherent and best justified in both Western (Judaism-Christianity-Islam) and Eastern (Hinduism-Buddhism) traditions" (Richard Swinburne, review of Death and Eternal Life, by John Hick, Religious Studies 13, no. 3 [Spr. 1977]: 185) ; Hick, Death and Eternal Life, 25. 
a statement is true when it is coherent with other ideas within a system as a whole.

Though it has not been precisely defined, the use of coherence theory is characteristic of the great philosophers in the history of philosophy. ${ }^{54}$ Alan R. White characterizes coherence theory in these words: "To say that a statement (usually called a judgment) is true or false is to say that it coheres or fails to cohere with a system of other statements." 55 Kirkham says, "Typically, then, a coherence theory of truth would claim that the beliefs of a given individual are true to the extent that the set of all their beliefs is coherent.” ${ }^{56}$ According to Kirkham, it can be argued that John Locke was the first who introduced this theory when he said that "ideas are true if they agree with each other."57 Therefore, the credibility of one's argument largely depends on whether it is coherent with his or her other ideas.

Pareschatology and Criticisms from Coherence Theory Every component of his religious pluralism, such as theology, Christology, soteriology, and eschatology, must work together to make Hick’s system stand firm. For Hick, not a single component is an insignificant part that can be ignored. Hick has taken a significant amount of time in dealing with some of those issues, particularly theology, Christology, and soteriology.

Because Hick’s pareschatology has a crucial function in his entire system of religious theory, it may serve as a testing measure of the validity or credibility for his

${ }^{54}$ Kirkham, “Coherence Theory of Truth,” 471.

55 Alan R. White, “Coherence Theory of Truth,” The Encyclopedia of Philosophy, ed. Paul Edwards (New York: The Macmillan Company and The Free Press, 1967), 130.

${ }^{56}$ Kirkham, “Coherence Theory of Truth,” 470.

57 Ibid. 
system as a whole. Like the previous discussion of correspondence theory, I shall now in light of coherence theory discuss three similar and three additional major theological topics that are relevant to Hick’s pareschatology: (1) principles of method, (2) anthropology, (3) theology of death, (4) afterlife, (5) soul-making, and (6) universal salvation.

\section{One: Principles of Method, Pareschatology and Coherence Theory}

As noted earlier, Hick offers a new approach in eschatology called pareschatology, "the doctrine of the para-eschata, or next-to-last things." ${ }^{58}$ Its major concern is "the human future between the present life and man's ultimate state," ${ }^{59}$ that is, the human state between the moment of death and ultimate salvation. A complete monograph, Death and Eternal Life, spells out his own model of eschatology, which can be summarized as a combination of eschatologies from East and West. ${ }^{60}$

In dealing with his new eschatological model, Hick presents two principles of method. The first principle of method is his claim to articulate only “possibilities” rather than "alleged certainties."61 However, what Hick actually is doing is more than presenting possibilities, but instead is, as he says, "building speculations upon

${ }^{58}$ Hick, Death and Eternal Life, 22.

59 Ibid.

${ }^{60}$ As Larry D. Shinn notes, Hick’s pareschatology is “a blend of the Christian (Irenaenian) teleological claim that all persons were created to seek fulfillment in God, with the Hindu and Buddhist notion of repeated births being needed for progress toward perfection to be realized” (Larry D. Shinn, "Death and Eternal Life,” Religion in Life 46, no. 3 [Aut. 1977]: 387).

${ }^{61}$ Hick, Death and Eternal Life, 22. 
speculations, "62 which in the end tend to coalesce into a specific pluralistic system, which, in my view, represents more than shifting possibilities. In fact, Hick’s reasoning behind doing pareschatology rather than eschatology is that "the subject-matter of pareschatologies is less remote and may be less incommensurate with our present existence than that of eschatologies.”63 This choice suggests that Hick wishes his theories to be more than possibilities but to correspond to reality.

Hick states his second principle of method as follows: "We must take account of the teachings of all the main religious traditions and philosophies, and also of work in the still fairly new parascience of psychical research, as well as of the relevant findings of such orthodox sciences as anthropology, sociology, psychology and genetics. ${ }^{64}$ In other words, Hick's pluralism leads him to claim that his theory is informed by all possible data for his inquiry of pareschatology, yet he ends up limiting himself to two major options from East and West. ${ }^{65}$

Returning to his first methodological principle of offering only possibilities, I suggest that Hick is not completely consistent within his own system. The main purpose of his hypothesis, as he notes, is to "spell out possibilities rather than to deal in alleged certainties. ${ }^{, 66}$ In doing so, he differentiates his eschatological model (pareschatology)

${ }^{62}$ Ibid., 420.

${ }^{63}$ Ibid., 23.

${ }^{64}$ Ibid., 26.

${ }^{65}$ Starting with three options-(1) the humanist view of no survival after death, (2) the Western and Christian view of heaven or hell, (3) the Eastern view of reincarnation-Hick ends up having a combination of the latter two as his eschatological model, that is, resurrection and reincarnation (ibid., 28).

${ }^{66}$ Ibid., 22. 
from conventional eschatology in the sense that the former is less remote and may be less incommensurate with the present life than the latter. Though admitting the obscure nature of the subject matter of pareschatology, Hick argues that "there may be degrees of obscurity. ${ }^{, 67}$ Here, Hick seems to claim that pareschatololgy is more easily accessible than eschatology as if there exist degrees of ambiguity in knowledge of the future. And he adds, "If there is life after death there may be a better possibility of picturing its more proximate than its more ultimate phases." ${ }^{\text {68 }}$ Regardless of his distinction between them, the bottom line is that they both deal with the human future, which is the unknown world. Nevertheless, Hick insists that the fact that relative nearness of the subject matter of pareschatology to our present existence convinces him that his speculation about it is "not wholly misleading." ${ }^{69}$ In other words, he wants to claim his pareschatology is looking in “a right direction, or ... not looking in a totally wrong direction." ${ }^{, 70}$ This claim seems more than a possibility, and more like an assured claim, which seems inconsistent with Hick’s general method of dealing only with possibilities.

A further example that Hick presents more than just possibilities is evident in his book entitled, Death and Eternal Life. In this volume Hick presents a theory represented as a global theology of death, which trumps all other eschatologies and pareschatologies. The manner of his writing in Death and Eternal Life is not merely spelling out a potential direction or a possibility, but rather a well-developed theory or strong conviction. He dismisses some theories and beliefs as less probable, while he accepts others as more
${ }^{67}$ Ibid.
${ }^{68}$ Ibid.
${ }^{69}$ Ibid.
${ }^{70}$ Ibid., 23. 
probable. In this Hick is charting a right way and in so doing seems to contradict his stated method of dealing only with possibilities.

Returning to the second principle of method that he calls "the principle of openness to all data,” Hick is inconsistent by limiting his discussion first to three then to two models concerning human future after death, namely, eschatologies from East and West. Hick says, “Taking seriously the variety of human views concerning man’s destiny does not necessarily require an encyclopedic treatment of after-life beliefs throughout the world and throughout ages." ${ }^{71}$ Though claiming in the sentence just quoted that he is not obliged to take every eschatological model into consideration, his all-data principle points toward an inconsistency in his acceptance of only three and later two options in eschatology. One would think that Hick should at least include some major eschatologies from, for example, Chinese, African, and South American religions. While Hick may feel that the rest of eschatological beliefs can be seen as "the details of the innumerable overlapping religious and philosophical thought-worlds,"72 which can, therefore, be categorized into these two major options, it seems to me that such uncritical theoretical enfolding of such large world religion eschatological views into two representative options from East and West seems like an act of overgeneralization, and one that is out of harmony with his idea that his pareschatology needs to be informed by an "all data" principle. For instance, I find little if any discussion of the eschatologies from Chinese, African, or South American religions.

\footnotetext{
${ }^{71}$ Ibid., 27.

72 Ibid.
} 


\section{Two: Anthropology, Pareschatology and \\ Coherence Theory}

It is important here to review again Hick's view of man in a slightly expanded version, because his anthropology, particularly how humans came to exist, will have a significant impact on Hick’s account of man’s future destiny beyond death. As a serious thinker Hick, of course, tries to be as consistent as possible in his theory of human being within the system of his religious pluralism. Hick argues, "I have tried not to be blinded by my own particular starting-point to insights and suggestions coming from beyond the Christian and Western traditions.”73 Though he claims in this sentence not to be blinded by a Christian perspective, his approach to anthropology is grounded upon a Christian foundation. In this sense, he is not completely free from a criticism of being inconsistent in his claim of not being influenced by a Christian vantage point.

Another point of inconsistency concerns Hick’s use of evolutionary science in his account of human origin. Hick understands humanity as God's creation whom God is forming into his own image and likeness as described in Gen 1 and 2. However, due to Hick’s alliance with the liberal theology which claims that when the Scriptures are properly understood and interpreted there is no conflict between science and theology, ${ }^{74}$ he reinterprets the Genesis account of human creation by changing the method of creation. Rather than interpreting the Genesis account as a literal and historical event, he understands it as mythology.

73 Ibid., 28.

${ }^{74}$ See Pierard, “Theological Liberalism,” 683. 
Accordingly, Hick argues that "man was brought into existence by the slow process of evolution out of lower forms of life" ${ }^{75}$ through the invisible hand of God. In other words, as he notes, “God’s creative work is progressive and continuous and that biological evolution is a part of it." ${ }^{76}$ He does not want to completely relinquish his Christian background, affording him a firm conviction in ultimate divine Reality. However, though acknowledging man as God's creature, Hick adopts a middle way between creationism and evolution in regard to human origin, ${ }^{77}$ known as theistic evolution. Keith Ward defines theistic evolution as a process in which "natural causal processes are influenced or modified (not violated or 'broken') by specific divine intentions. ... [Thus] God causally influences evolution.”78 This is a compromise position respecting both creationism and evolution. From the creationist point of view, Hick's God is subordinated to the power of natural laws. From an evolutionist point of view, which excludes any teleological supernatural action within the realm of natural

75 John Hick, "The Problem of Evil in First and Last Things," The Journal of Theological Studies 19, no. 1 (Apr. 1968): 597.

${ }^{76}$ Hick, “A Remonstrance in Concluding,” 212.

${ }^{77}$ Regarding the basic issue of the method of origins, John T. Baldwin notes that while some writers laud Darwin's insight of natural selection and its "effectiveness in the clearly obvious process of microevolution as it accumulates small variations in populations ... . [they] question whether we can properly extrapolate microevolution as capable of producing the large and complex change evident between biological forms considered, for example, at the taxonomic ordinal level” (John T. Baldwin, "Introduction," in Creation, Catastrophe, and Calvary, ed. John T. Baldwin [Hagerstown, MD: Review and Herald, 2000], 7).

${ }^{78}$ Keith Ward, “Theistic Evolution,” in Debating Design, ed. William A. Dembski and Michael Ruse (Cambridge: Cambridge University Press, 2004), 273. Hick uses words such as "divine intervention," and "programming” to describe God's influence in creation. See Hick, Death and Eternal Life, 44, 48, 457. According to this theory, as Warren C. Young notes, "Evolution became simply the methodology used by God to bring to pass the various forms of life" (Warren C. Young, A Christian Approach to Philosophy, Twin Books Series [Grand Rapids, MI: Baker Book House, 1973], 92). 
laws, the idea of divine creative action that Hick assumes to be operative within the evolutionary process is simply unacceptable. To conventional evolutionists there is no place for in any sense to be guiding or teleologically influencing the evolutionary process. In a naturalistic evolutionary model, man is the sheer result of a wholly natural process called evolution without any supernatural Reality involved.

According to the above analysis, it seems inconsistent or incoherent for Hick to claim that biological evolution, conventionally understood, is part of God's creative work, because Hick does not actually accept the evolutionary process per se, since he allows God to guide in the so-called evolutionary process. As noted above, wholly naturalistic evolution and theistic evolution represent mutually exclusive methodologies of origin. In the former, humans emerge without reference to or the need of divine action. In the latter, humans cannot emerge without reference to or the need of God's action.

A further point that needs to be noted is that Hick’s strong reliance on scientific theory in his anthropology may become problematic, because it involves a potential inconsistency currently contested. ${ }^{79}$ Knowing that scientific theories that were believed to be true have changed throughout time, the question is, How much can we rely on a

${ }^{79}$ The question is What is science? I think it is better to say, scientific knowledge rather than just saying science, because the word science can be too vague and broad to be defined. To Hick science roughly means "the physical sciences [or natural science] as distinguished from psychology and the social sciences” (Hick, Science and Religion, para. 1). This, however, does not mean what is usually called naturalism or physicalism which claims that "the physical universe constitutes the totality of reality" (ibid.). In the most general sense, science means natural (or physical) science which used to be understood as permanent truth due to the influence of Aristotle's or Newton's principles. But as Stephen Toulmin notes, "natural science no longer makes any claim to permanent or fixed ideas" (Stephen Toulmin, “The Historicization of Natural Science: Its Implications for Theology," in Paradigm Change in Theology, ed. Hans Küng and David Tracy [New York: Crossroad, 1991], 236.). If natural science is in constant radical change, Toulmin argues that "it will be better if theologians heed the skeptics, free themselves from the seduction of 'new paradigms,' and become frankly reconciled to being (in that sense) 'paradigmless'” (ibid., 237). 
particularly scientific theory ${ }^{80}$ Hick's evolutionary approach in anthropology, ${ }^{81}$ which is based essentially on a nineteenth-century scientific hypothesis, is now becoming in some academic circles an unconvincing hypothesis that requires major revisions. ${ }^{82}$ The way Hick has treated other issues ${ }^{83}$ shows that he would change his views whenever convincing new scientific findings become available. It is evident that historically scientific theories have been modified and changed in proportion to the amount of scientific knowledge people have acquired. By adopting the basic nineteenth-century

${ }^{80}$ In regard to continuous modification of evolutionism throughout history, Gregory P. Elder rightly notes, "To accept any current scientific position as the sole basis for doctrine is to doom any such doctrinal system to eventual obsolescence" (Gregory P. Elder, Chronic Vigour: Darwin, Anglicans, Catholics, and the Development of a Doctrine of Providential Evolution [Lanham, MD: University Press of America, 1996], 184).

${ }^{81}$ Hick, "The Problem of Evil in First and Last Things," 596, 597. Hick considers the story of Genesis as "the Hebrew myth of the beginning." And he says, "All the evidence that we have suggests man's continuity with lower forms of life and indeed with nature as whole, and his complete involvement from the beginning in the harsh necessities of the struggle for survival” (ibid., 596).

${ }^{82}$ William A. Dembski, "Introduction: The Myths of Darwinism," in Uncommon Dissent, ed. William A. Dembski (Wilmington, DE: ISI Books, 2004). William A. Dembski claims that evolutionism (or Darwinism) is not a convincing argument anymore. Thus he says that "Darwinism will be history" (ibid.). Thus, John Polkinghorne, a theistic evolutionist, notes, "At the scientific level, there were contemporary biological critics of the idea of evolution by natural selection, like Sir Richard Owen, the greatest anatomist of the day, who pointed to difficulties in Darwin's thesis. ... The greatest British physicists of the nineteenth century, such as Faraday, Maxwell and Strokes, were silent in public but privately had doubts about the unaided adequacy of natural selection to explain the development of life in the timescale available" (John Polkinghorne, Science and Theology: An Introduction [Minneapolis, MN: Fortress Press, 1998], 7). See also William A. Dembski and James M. Kushiner, eds., Signs of Intelligence: Understanding Intelligent Design (Grand Rapids, MI: Brazos Press, 2001); Michael Ruse, Darwin and Design: Does Evolution Have a Purpose? (Cambridge, MA: Harvard University Press, 2003); Howard J. van Till, Davis A. Young, and Clarence Menninga, Science Held Hostage: What's Wrong with Creation Science and Evolutionism (Downers Grove, IL: InterVarsity Press, 1988).

${ }^{83}$ For instance, he has changed his views on Christology several times as his theological journey matured. 
evolutionary model as the fundamental basis for his understanding of human origin, death, and pareschatology, Hick may find himself in a dilemma of being tied to a scientific theory which may be doomed to possible "eventual obsolescence," ${ }^{84}$ and thus to incoherence unless Hick would be willing to change his views.

\section{Three: Theology of Death, Pareschatology and Coherence Theory}

In dealing with an issue universal to every religion, namely the reality of death, Hick shows his pluralistic approach in an apologetic tone by not only discussing it in the realm of religions but in the realm of other disciplines such as science, philosophy, anthropology, sociology, biology, etc. This open attitude to all available data leads Hick to have a global approach in doing theology, particularly a global theology of death. The global theology of death is a very important task in Hick's whole agenda of doing religious pluralism, because his theology of death is a good test case revealing whether one component fits coherently into his entire system of religious pluralism.

In the section discussing "The Idea of a Global Theology of Death," ${ }^{85}$ Hick mentions the distinction between religions' central affirmations and the mythology which comes with them. Whereas central affirmations of religions are mainly a matter of either true or false, Hick argues that the mythology in the religions is not in the same sense true or false. ${ }^{86}$ Thus, Hick divides religious beliefs into two classes, one class being central,

${ }^{84}$ Elder, Chronic Vigour: Darwin, Anglicans, Catholics, and the Development of a Doctrine of Providential Evolution, 185.

${ }^{85}$ Hick, Death and Eternal Life, 29-34.

${ }^{86}$ Ibid., 29. 
thus either true or false, and the other class being myth or marginal. ${ }^{87}$ Criteria formation for this distinction seems fluid. Some ideas which are central at times become marginal, thus often being treated as "poetic elaborations . . . cultic expressions" 88 in Hick's model. ${ }^{89}$ For instance, to a conservative Christian the story of the Fall and death described in Gen 3 are literal and historical events; thus they are considered as central Christian doctrines, but they are understood and categorized as mythology by Hick. By applying this method of distinguishing between these two categories, Hick opens the way to anticipate the possibility of constructing a global theology. ${ }^{90}$

According to the distinction between what is central and what is marginal, theological differences between religions regarding death appear not to be religiously critical. Thus, Hick finds no difficulty in doing "a comprehensive global theology,"91 in which agreements and disagreements can coexist. As long as "both correct and incorrect trans-historical beliefs . . . can form part of a religious totality" 92 and allow us to experience the Real and salvific transformation, Hick thereby renders all religions valid. Evidently, according to this understanding, the correctness or incorrectness of theology

${ }^{87}$ He uses the words "two aspects of a religion" to describe this distinction between central and marginal truths (Hick, Death and Eternal Life, 29).

${ }^{88}$ Ibid.

${ }^{89}$ The doctrine of incarnation is one of the most important doctrines in Christianity, but it is understood as myth in Hick's system.

${ }^{90}$ Though Hick pursues the possibility of a global theology, he does not look for a global religion that will dominate all world religions. The question is, then, What is the purpose of theology? Is it only for understanding each other's differences or also for achieving better relationships among world religions?

${ }^{91}$ Ibid.

${ }^{92}$ Hick, An Interpretation of Religion: Human Responses to the Transcendent, 370. 
seems to be of little importance. In other words, Hick's theological view, that correctness or incorrectness in theology is not significant as long as these conflicting concepts form part of a religious totality, suggests to me that Hick believes that differences between the theologies of death among world religions appear not to be religiously critical. However, this view seems to be inconsistent with his own effort to develop what he considers to be a true hypothesis of death.

Looking at the reality of death from a different angle inspired by Irenaean theology, Hick introduces a new vision regarding death. Whereas traditional Christianity understands death as the result of sin, thus seen as "a divinely inflicted punishment for sin," ${ }^{93}$ Hick understands death as part of the original will of God for humans. This understanding allows people to move from one world to another, and enables personal growth in the likeness of God after death. If at the moment of death people move from this world to another to have another and better chance than they now have, death is something to be seen not only positively but something desirable. As Robison notes, Hick "almost glorifies death. He sees death as a point of transition, a progress report on one's journey toward God." 94 This line of argument is presented in his Evil and the God of Love, where the Irenaean model is favored over the Augustinian in theodicy. Then the question can be raised in response to Hick's position: Why in reality do the majority of people fear death rather than facing it with joy? ${ }^{95}$ Empirically speaking, it is very unlikely to say that death is something people desire. On the contrary, if Hick is willing 179.

${ }^{93}$ Hick, Death and Eternal Life, 190.

${ }^{94}$ Robison, Life after Death? Christian Interpretation of Personal Eschatology,

${ }^{95}$ This question also involves the correspondence issue because it is not what we normally perceive in the real world. 
to be open to all possible data including the general negative experience of people toward death, ${ }^{96}$ it seems incoherent, as Hick proposes, that all people should reject the idea that death is something to be avoided and feared by everyone. The theories of death held by these other people groups declare otherwise. For example, in Oriental culture where death is sometimes interpreted as offering another chance, death is still regarded as an undiscovered realm and thus remains a fearful experience that takes away everything from us.

\section{Four: Afterlife, Pareschatology and Coherence Theory}

Though Hick seems to be somewhat uncertain about empirical evidence concerning life after death, relying largely on parapsychology ${ }^{97}$ in the form of spirit communications through mediums, he tries to provide some evidences. His use and acknowledgment of parapsychology shows the mystic and meta-scientific nature of his thinking, which is rather surprising to be found in the work of one who gives such high credit to the conventional scientific method. Admitting the uncertain nature of empirical evidence of life after death, Hick contends that this situation "does not mean that there is no life after death.”98

${ }^{96}$ Hick, Death and Eternal Life, 28.

${ }^{97}$ See ibid., $129-146$.

${ }^{98}$ Hick, Disputed Questions in Theology and the Philosophy of Religion, 187. In regard to the life after death, as Harry Buis notes, "Hick rejects the secular view that there is no life after death in favor of the religious view that there is" (Harry Buis, review of Death and Eternal Life, by John Hick, Reformed Review 49, no 2 [Wint. 1995-1996]: 139). See also James W. Woelfel, review of Death and Eternal Life, by John Hick, Dialog 16, no. 4 (Aut. 1977): 309. 
Hick presents a line of argument for the existence of a soul-making afterlife upon the rational and moral argument that the idea of an eternal hell following a short sinful earthly life is not morally acceptable. Hick thinks the concept is inconsistent with the idea of a loving God. ${ }^{99}$ I suggest that Hick’s pareschatology represents his response to the classical theodicy problem, the existence of evil in the presence of the perfectly good God, or in his Kantian term, in view of his "cosmic optimism.” As Wilko van Holten notes, "the idea of eternal punishment is not compatible with the perfect goodness of God.” ${ }^{100}$ Hick’s pareschatological soul-making process ideationally solves the hell problem in an effort to support the perfect goodness of the Real, which will be discussed more fully later.

While Hick's motive to preserve the goodness of the Real is commendable, I will briefly spell out one criticism concerning his views on the issue. The criticism comes from recent New Testament research suggesting that Hick misunderstands the biblical teaching about hell. ${ }^{101}$ In his interpretations of biblical accounts, whenever Hick finds

${ }^{99}$ For more about the eternal torment of hell and the God of infinite love see Hick, Death and Eternal Life, 200-201. For the traditional doctrine of hell, see Peter Geach, Providence and Evil (Cambridge: Cambridge University Press, 1977), 123; Richard Swinburne, "A Theodicy of Heaven and Hell," in The Existence of God, ed. Alfred J. Freddoso (Notre Dame: University of Notre Dame Press, 1983), 52; Wilko van Holten, "Hell and the Goodness of God," Religious Studies 35 (Mar. 1999): 39.

${ }^{100}$ van Holten, "Hell and the Goodness of God," 38.

${ }^{101}$ Hell in the Bible, as conditionalists note, is not an actual place where the eternal fire is burning sinners forever. Rather it is understood as a state of punishment that the lost will face at the time of judgment. The extermination of sinners will occur and its result will be eternal. Thus, Donald Guthrie says, "The doctrine of eternal punishment is not an attractive doctrine and the desire to substitute for it the view that, at the judgment, the souls of the wicked will cease to exist, is understandable" (Donald Guthrie, New Testament Theology [Leicester: IVP, 1981], 892). For more about the traditional understanding of hell see Jaime Clark-Soles, Death and the Afterlife in the New Testament (New York: T \& T Clark, 2006); Tony Gray, "The Nature of Hell: Reflections on the Debate between Conditionalism and the Traditional View of Hell," in Eschatology 
conflicts between the Bible and science, he simply reinterprets the biblical texts in order not to be in conflict with science. The mythological interpretation of biblical texts is his way of getting rid of these apparent conflicts. However, in the case of the notion of hell as it appears in the Bible and is interpreted in his Calvinistic tradition as a literal place where the lost would suffer forever right after death, ${ }^{102}$ Hick does not apply the mythological interpretation as he does with other texts, which could have saved him from several difficulties regarding hell as classically understood. This shows an inconsistency in Hick's biblical interpretation of hell and the afterlife. Thus, the inconsistency of Hick's biblical hermeneutic along with his resultant misunderstanding of hell leads him to develop his pareschatology as the solution to the original theodicy issue.

\section{Five: Soul-Making, Pareschatology and Coherence Theory}

As one who inherits the theological legacy of Irenaeus and later of

Schleiermacher, ${ }^{103}$ Hick emphasizes the importance of the soul-making aspect of the

in the Bible and Theology: Evangelical Essays at the Dawn of a New Millennium, ed. Kent E. Brower and Mark W. Elliott (Downers Grove, IL: InterVarsity Press, 1997); Xavier Léon-Dufour, Life and Death in the New Testament: The Teachings of Jesus and Paul (New York: Harper \& Row, 1979); René Pache, The Future Life (Chicago: Moody, 1962); Geoffrey Rowell, Hell and Victorians (New York: Oxford University Press, 1974); Daniel P. Walker, The Decline of Hell: Seventeenth-Century Discussions of Eternal Torment (Chicago: University of Chicago Press, 1964).

${ }^{102}$ The reason behind this thought is that the idea of hell is incompatible with God's goodness (Hick, Death and Eternal Life, 201). Hick's Irenaean theodicy is based upon his Christian understanding of God and his goodness. Ironically, however, he considers this whole idea of theodicy proposed in Evil and the God of Love as mythology in his An Interpretation of Religion. This does not mean that Hick has relinquished his theodicy as a whole. By claiming that it is "a true myth," he has kept the basic structure of theodicy that evil contributes something in our soul-making in the view of his "cosmic optimism" (ibid., 360, 361).

${ }^{103}$ See Hick, Evil and the God of Love, 201-235. 
present world. ${ }^{104}$ Hick says that "our present world is not intended to be a paradise . . . but rather a place of soul-making, an environment in which creatures made as rational and personal in the image of God can grow towards the finite likeness of their maker.” ${ }^{105}$ Furthermore, as Mesle notes, Hick suggests that "the world is designed to begin a process of soul-making that continues into eternal life.”106 That is, Hick’s process of soul-making will continue to take place until it will be completed at the point of perfection in the intermediary state involving many afterlives if needed. The basic idea is that the Real, who exercises infinite love toward us in eternity, can and will bring everyone to the salvific relationship with him at last.

The notion of soul-making is crucial to Hick’s project of pareschatology because it helps us to understand the meaning of life and its toilsome journey with a different view. In other words, Hick’s theology of soul-making does not emerge merely from his

${ }^{104}$ As Graves notes, “Basic to Hick’s position is the developmental stance of Irenaeus who pictures the creation of person as an ongoing process. The early church father pictured Adam created not as a finished product, but as an immature being in need of moral development” (Thomas H. Graves, “A Critique of John Hick's Theodicy from an African Perspective,” Perspectives in Religious Studies 18, no. 1 [Spr. 1991]: 31). See also Helen Oppenheimer, review of Death and Eternal Life, by John Hick, Theology 81, no. 681 (May 1978): 209.

105 John Hick, “God, Evil and Mystery,” Religious Studies 3 (Apr. 1968): 540. Here Hick shows that he has applied the principle of evolution that human beings evolve from dust to a rational being to a perfected being at last. According to Hick, human beings are not created as perfect beings as Augustinian claims. As noted earlier in the dissertation, Hick adopts Ireneaus's distinction between "the image and likeness" of God in Gen 1:26. Though Hick says human beings are endowed with "the image of God" at creation, they do not yet have "the likeness of God" which would be acquired in time.

${ }^{106}$ C. Robert Mesle, “The Problem of Genuine Evil: A Critique of John Hick’s Theodicy,” The Journal of Religion 66, no. 4 (Oct. 1968): 414. Regarding the vale of soul-making, Roland Puccetti says: "To achieve a likeness to God men must perfect themselves, or at least begin to perfect themselves, in this life" (Roland Puccetti, "The Loving God: Some Observations on John Hick's Evil and the God of Love,” Religious Studies 2 [Apr. 1967]: 259). 
intellectual exercise but from a totality of religious, academic, and social struggles concerning human existence. People often see life as full of unfairness, injustice, and suffering, which seems to torture us and block our steps to the Real. However, with an insight that he received from Irenaeus, who sees, in the words of Hick, "moral evil as an inevitable result of God's creation of man as an immature creature," ${ }^{107}$ Hick offers a different view of the meaning of life and as Graves notes, "emphasizes the positive and educative value of evil." ${ }^{108}$ Hick points out that the traditional Christian view of evil leads us to overlook "the positive reality in moral evil.." ${ }^{109}$ He even says that "morally evil actions are authentically and positively evil, not only as causes of pain and suffering but also as expressions of the evil willing that produces them." ${ }^{110}$

All of these arguments noted above bring us to the anthropological issue of how human beings emerged as God's creatures. Based on Irenaean theology and a mythological understanding of Genesis, ${ }^{111}$ Hick seems to argue that if God purposely created us as fallen beings, because such a condition is necessary to achieve salvation

${ }^{107}$ Hick, Evil and the God of Love, 369, quoted in Panthanmackel, "Problem of Evil: Hick’s Sublimation of Plantinga,” 256. 31.

${ }^{108}$ Graves, “A Critique of John Hick’s Theodicy from an African Perspective,”

${ }^{109}$ John Hick, Evil and the God of Love (London: Macmillan, 1966), 64.

${ }^{110}$ Ibid. For more about the current discussion of evil see Gaymon Bennett et al., eds., The Evolution of Evil (Göttingen: Vandenhoeck \& Ruprecht, 2008).

${ }^{111}$ In regard to the state of human beings at creation, Hick says: "If we use the mythological language of Genesis we have to say that man was created in a fallen state. He was not created as a righteous and holy being who later fell into animal selfcentredness in the struggle for survival within a harsh environment, but he was created in these conditions, and yet with a potentiality to transcend them. He was brought into existence as an immature creature, at the beginning of a long spiritual pilgrimage" (Hick, "Coherence and the God of Love Again," 523-524.). 
through pareschatological soul-making, we must say that it is not only positive but good that we are sinful. Hick himself applies the "O flex culpa” (in his own translation "O fortunate crime”) ${ }^{112}$ principle in his treatment with evil and human suffering, thus making evil as a part of human existence. This line of reasoning leads us to think that evil is not only positive, but instrumental, and is necessary for the soul-making process. ${ }^{113}$ In order to emphasize the instrumental value of evil, Hick claims that "some forms of environmental challenge and danger are needed if the world is to function as a place of person-making for morally and spiritually immature creatures.”114 The same conditions would seem to pertain also to the intermediate or to the pareschatological state. Clearly, evil, as Illtyd Trethowan states, “is a necessary means to an end.” 115 However, if, as Hick claims, a morally perfect, infinitely good, and powerful God must use evil instrumentally in soul-making, it seems that God does so on pain of moral inconsistency.

In this context, the question can be raised whether the Law of God itself or any state of God itself, not evil, can sufficiently test free agents in an evil-free environment. If so, this renders evil instrumentally unnecessary for the soul-making process. However,

${ }^{112}$ Hick, Evil and the God of Love, 400. See also Robert J. Russell, “The Groaning of Creation,” in The Evolution of Evil, ed. Gaymon Bennett et al. (Göttingen: Vandenhoeck \& Ruprecht, 2008), 138.

${ }^{113}$ Mesle's argument of malaria gives an insightful response to the argument of evil as instrumental in the world. He says that such an argument "begs the question in exactly the same way that some people do when they insist that we ought to praise the Lord for malaria since without it we would not have developed malaria vaccine. The problem with the argument is obvious: we would rather do without both the vaccine and the malaria. That is the whole point of having the vaccine" (Mesle, "The Problem of Genuine Evil: A Critique of John Hick’s Theodicy,” 426).

${ }^{114}$ Hick, Evil and the God of Love, 380.

115 Illtyd Trethowan, “Dr. Hick and the Problem of Evil,” The Journal of Theological Studies 18 (Oct. 1967): 411. 
Hick’s mythological interpretation of Gen 1-3 prevents him from considering or adopting such a world view.

\section{Six: Universal Salvation, Pareschatology and Coherence Theory}

An inevitable notion that emerges out of Hick’s pareschatology is the doctrine of universal salvation that everyone will eventually be saved after many repeated lives as "a gradual move toward God.”116 Hick develops his doctrine of universalism on the basis of two ideas: the goodness of God (or the Real) ${ }^{117}$ and the omnipotence of God. ${ }^{118}$ It is important to recall Hick’s attitude toward such qualities of the Real. Hick makes the following comment regarding these qualities: “[W]hen it is said that God is wise or that God is good, these qualities are thought to be analogous to rather than identical with human wisdom and goodness."119

The basic reasoning is that if God is good and all-powerful, he can and will save all. These two attributes of God guarantee the salvation of all no matter how wicked they are. Thus, as van Holten notes, "Hick repudiates the idea of eternal punishment for this doctrine has as its implied premise either that God is only limitedly good (he does not 186.

${ }^{116}$ Robison, Life after Death? Christian Interpretation of Personal Eschatology,

${ }^{117}$ Hick, Death and Eternal Life, 250-251.

118 Ibid., 251. See also Richard Swinburne, “The Problem of Evil,” in Contemporary Philosophy of Religion, ed. Steven M. Cahn and David Shatz (New York: Oxford University Press, 1982), 3. 351.

${ }^{119}$ Hick, An Interpretation of Religion: Human Responses to the Transcendent, 
want to save all) or he is only limitedly sovereign (he cannot save all)." ${ }^{120}$ In doing so, Hick confronts the problem of human freedom. Does God overrule the will of rebellious human beings, so that all humanity will be saved? As van Holten observes, “Genuine human freedom seems to prohibit drawing the universalist conclusion” that everyone will be saved eventually. ${ }^{121}$

In response to this apparent "antinomy"122 Hick provides a twofold solution mainly by giving a new interpretation of human freedom ${ }^{123}$ and the postulation of multiple afterlives. Concerning the first dimension of the solution, Hick, as one who espouses the minority view of Irenaean theodicy against the majority view of Augustinian theodicy, adopts at least one significant point in Augustinian anthropology that, in Hick's

${ }^{120}$ van Holten, "Hell and the Goodness of God,” 45. See John Hick’s "Afterword," in R. Douglas Geivett, Evil and the Evidence for God: The Challenge of John Hick's Theodicy (Philadelphia, PA: Temple University Press, 1993), 229.

${ }^{121}$ van Holten, "Hell and the Goodness of God," 46. See also Wainwright, Review of Death and Eternal Life, 345. Stephen H. Davis rightly notes that while Hick is "right to assert that God's will is to draw all men to himself, he underplays man's freedom-which is itself a gift of God's love-to resist him” (Stephen H. Travis, "The Problem of Judgment,” Themelios 11, no. 2 [Jan. 1986]: 55).

${ }^{122}$ Hick, Death and Eternal Life, 243. Hick thinks the New Testament does not completely rule out the idea of universalism (ibid., 243-250).

123 Though he tries to solve the problem by providing a new meaning of freedom, Hick is not able to do away with the basic meaning of freedom, as Plantinga notes: "If a person is free with respect to a given action, then he is free to perform that action and free to refrain from performing it; no antecedent conditions and/or causal laws determine that he will perform the action, or that he won't. It is within his power, at the time in question, to take or perform the action and within his power to refrain from it” (Alvin Plantinga, God, Freedom, and Evil, Essays in Philosophy, ed. Arthur C. Dante [London: George Allen \& Unwin, 1975], 29). See also Hick, "Freedom and the Irenaean Theodicy Again," 420. 
words, "God has so made us that the inherent gravitation of our being is towards him.",124 Hick argues that because of God's image in us, “man’s nature is not neutral or alien towards his maker . . . but is inwardly structured towards him.” ${ }^{125}$ However, Hick also indicates that in this world the whole life of some individuals represents a "regress”"126 from the Real. Hick's thought that some never progress toward the Real in this life, but regress, is in conflict with his idea of the inherent gravitation of our being toward the Real and that humans are naturally not alien toward their maker.

Nevertheless, according to Hick, our natural inward gravity towards God means that God does not have to coerce us to save us, for he has already created us in such a way that all humans will come to love and worship him. Thus, Hick offers the following conclusion: "The faith that God has made us for fellowship with himself, and that he so works in his creative power as to enable us to reach that fulfillment, carries with it the faith that in the end all human life will . . . be saved."127 In this way, Hick’s pareschatology leads to universal salvation in a real sense. However, this result seems to

${ }^{124}$ Hick, Death and Eternal Life, 251. Hick argues that within a “dual nature”-”a basic instinct for self-preservation" and the inherent gravitation of human beings "toward God”-humans exercise their freedom (Hick, “Afterword,” 235.).

${ }^{125}$ Hick, Death and Eternal Life, 252.

${ }^{126}$ Ibid., 155.

${ }^{127}$ Ibid., 259. As John M. Rist notes, "Hick is prepared to admit that there must be logical possibility that all men may not respond to God's desire for universal salvation, but claims that God will with His infinite resourcefulness be able to re-establish those who have consistently chosen vice in preference to virtue on the true path. This, Hick claims, is a practical certainty” (John M. Rist, "Coherence and the God of Love,” Journal of Theological Studies 23, no. 1 [Apr. 1972]: 100). For more about God’s saving power and human freedom, see Hick, "Freedom and the Irenaean Theodicy Again," 527; G. Stanley Kane, "Freedom and the Irenaean Theodicy,” The Journal of Theological Studies 20, no. 1 (Apr. 1969): 249; Keith Ward, "Freedom and the Irenaean Theodicy," The Journal of Theological Studies 20, no. 1 (Apr. 1969): 210-220. 
place Hick's notion of universal salvation into the category of a certainty, and not only a possibility, and so stands in conflict with Hick's method of advancing only possibilities.

The second aspect of the solution comes in the form of his core idea of pareschatology, which can be expressed as follows. An "intermediate state" or the multiple repetitions of life after death allow God's salvific presence to act upon us until we reach the final perfection of humanity. Assuming the reality of an intermediate state, Hick contends, "If there is continued life after death, and if the Real is ceaselessly at work for the salvation of his children, it follows that he will continue to be at work until the work is done."128

By acknowledging the gap between the individual's imperfection at death and the person’s needed perfect heavenly state, I suggest that Hick in effect argues that there must be an intermediate state or bridge similar to purgatory in which "progressive sanctification after death" is to take place before the final perfection of being. ${ }^{129}$ In other words, Hick's notion of an intermediate state is a revised and expanded version of the Roman Catholic idea of purgatory that he characterizes as "the period between this life and man's ultimate state.” ${ }^{130}$ Whereas the Catholic notion of purgatory limits its efficacy to some, Hick's pareschatology is efficacious for all. This means that the notion of “intermediate state” has an assumption that there are, as van Holten notes, “afterlife possibilities of reform for all those not yet saved.”131 This intermediate state between death and the ultimate salvation is a core part of Hick's pareschatology, in which the Real

\footnotetext{
${ }^{128}$ Hick, Death and Eternal Life, 258.

${ }^{129}$ Ibid., 202.

130 Ibid.

${ }^{131}$ van Holten, "Hell and the Goodness of God," 46.
} 
continues to work for his beloved people to save them all. Thus, Hick's pareschatology, which originally had emerged from his struggle with the problem of theodicy, now expands the Roman Catholic notion of purgatory to solve the original problem of evil. ${ }^{132}$

Concerning the temporal aspect of pareschatology, Hick argues that the duration of the intermediate state is different among people depending on their personal distance from the Real in their soul-making process. ${ }^{133}$ Hick does not provide an answer regarding why it takes almost an infinite time of afterlives for some, if God wills to save them. Hick's notion of almost infinite duration of afterlives for some humans seems inconsistent with the efficaciousness of God's love and omnipotence.

As a final consideration in this section, I return to the fundamental antinomy, and respond to a rhetorical question by Hick in support of an intermediate state for universalism: "Why should he (man) ever desire to reject the Lordship of the infinite Love in which, above all else, he rejoices?" ${ }^{134}$ For Hick, "it seems morally . . . impossible that the infinite resourcefulness of infinite love working in unlimited time would be eternally frustrated, and the creature reject its own good, presented to it in an endless range of ways." ${ }^{135}$ However, Hick’s appeal to universal salvation can also be posed in exactly the opposite way: Why should rebellious and wicked humans wish to accept the Lordship of the Real? The question then is, If the omnipotent God works successfully for the salvation of all, does this divine effort actually include all humans such as vicious

${ }^{132}$ Hick's creative use of the Roman Catholic insight of purgatory is only one of numerous examples of Hick applying his principle of religious pluralism.

${ }^{133}$ Hick, Death and Eternal Life, 419.

${ }^{134}$ Hick, Evil and the God of Love, 314.

135 Ibid., 380. 
criminals and even fallen angels? ${ }^{136}$ In other words, Hick’s argument in favor of universalism with the postulate of an intermediate state in the context of the theodicy problem, whether the intermediate state is short or almost infinitely long, does not seem to be coherent with the idea of genuine human freedom. Though Hick himself may not wish God to coerce human freedom, and though Hick’s use of a nearly infinite amount of time may be his attempt of enabling God to avoid overruling human freedom, and assuming that the human mind can become hardened in rebellion against God, it seems inevitable that in order for universal salvation to be accomplished, the omnipotent God sooner or later must overrule the will of hardened rebellious humans. This can be seen as a divine act of coercion. In other words, a God who brings all humanity, both repentant and unrepentant, to a state of loving God, must inevitably coerce those who reject him constantly which nullifies their freedom to choose him with their own will. In short, while Hick's universalism seems to offer a desirable answer for the theodicy problem, yet as a result, it has an internal incoherency problem with human freedom.

\section{Conclusion: Criticism of Hick's Religious Pluralism as a Whole}

By way of introduction, the fact that Hick's pareschatology has not received sufficient attention by philosophers and theologians has been a leading factor prompting me to write this dissertation. It has been my purpose to take a critical look at Hick's religious pluralism as a whole. As the purpose of the dissertation notes, my goal is to criticize Hick's religious pluralism as a whole in light of his pareschatology through two

${ }^{136}$ It seems to me that Hick does not mention anything about fallen angels and the possibility of soul-making in the future for them. This suggests that Hick demythologizes fallen angels and the figure of Satan. 
major theories of truth that he himself uses. Though this final section is rather short, it is a crucial part of the chapter and dissertation.

Since one’s theology is a result of one's personal as well as one’s theological experience, it must be seen in one’s lifelong context rather than as a disconnected issue. Thus we must consider Hick’s theology as a whole to be the result of his spiritual pilgrimage from a conservative Christian, to a liberal theologian, and finally to a religious pluralist, to understand Hick’s theological views. From this perspective, Hick’s theological pluralism seems to reflect a general coherence. However, this whole process of changing views seems to suggest that his theory is open to further revision and change at any time as he develops his theological understanding. Hick claims that his writings, which were produced over several decades, may embody "considerable developments, and even reversals of viewpoint,” which represents “a continuing intellectual pilgrimage.”137 Therefore, his pareschatology may be revised and changed in the future if he reaches additional theological insights.

Moreover, according to Hick’s religious pluralism, Christianity is only one of many different yet equally valid "perceptions and conceptions of ... the real or the ultimate.”138 Therefore, all religions are only different responses to the ultimate Real and thus have different perceptions of human destinies after death. Within this theological framework, Hick’s postulate of pareschatology is fitting. However, Hick’s pareschatology itself shows lack of solidity due to its own correspondence difficulties and internal inconsistency challenges, as I have elaborated in this chapter.

${ }^{137}$ Hick, “Straightening the Record: Some Response to Critics,” 188.

${ }^{138}$ Hick, “Religious Pluralism and Absolute Claims,” 194. 
In sum, because Hick's pareschatology is not free from critical correspondence and coherence problems, I conclude that Hick's religious pluralism as a whole is weakened. Accordingly, this whole circumstance can be compared with a building structure with several columns supporting the entire structure. If one foundational column—pareschatology—is disintegrating, the whole building—Hick’s religious pluralism per se—-sooner or later collapses. 


\section{CHAPTER VI}

\section{SUMMARY AND CONCLUSIONS}

In the previous chapters I have discussed possible issues regarding Hick’s pareschatology. In this concluding chapter, I turn first to a review of my findings regarding Hick’s life, religious pluralism and the nature of Hick’s pareschatology. Then I summarize my main criticisms of pareschatology in as sharp and succinct detail as possible. After discussing these major issues, I draw some final conclusions for the dissertation.

\section{Summary of Findings}

Hick’s Life and Religious Pluralism

Hick's life sketch shows that his religious pluralism was not merely a fruit of his intellectual experience, but of a lifelong struggle with his multidimensional religious, academic, and social life experiences. Accordingly, Hick’s religious pluralism must be seen in the light of his spiritual pilgrimage, from a conservative Christian, to a liberal theologian, and finally to a religious pluralist. This journey forms the context of the development of his pareschatology.

Hick’s pluralism combines four central theological themes such as theocentrism, theology of the Real, Christology, and soteriology. These theological foci are addressed in this dissertation, because they all together, along with pareschatology, form Hick's religious pluralism as a whole. 
At the center of Hick's theology of world religions lies the notion of the Real. Hick calls this theocentric approach in doing theology a “Copernican revolution,” which marks a major shift from emphasis on ecclesiology and Christology to a focus on theocentrism. By this concept of the Real, who is at the center of the universe of faiths, Hick finds a solution for conflicts among world religions.

Though Hick acknowledges that the Real an sich is unknown and unknowable, he postulates it on the basis of its multiple phenomenal appearances in various world religions through his adoption of Kantian epistemological insight of distinction between noumenon and phenomenon. However, I suggest, in so doing, Hick's notion of the Real, the unknowable or the ultimate noumenon, becomes knowable only as a hypothetical construct, about which I comment in the section below entitled, “Criticisms of Hick's Pareschatology.”

Hick’s theocentrism inevitably leads him to reinterpret the classic doctrine of the Incarnation. No matter how subtly Hick articulates Christology, the final result of Hick’s theocentrism is a denial of the Incarnation, which in turn is one factor leading him to a mythological reinterpretation of the Scriptures.

Finally, Hick’s soteriology reveals his religious pluralism which claims that all religious traditions offer salvation by their own responses to the Real. Hick's notion of the process of human salvation involves not only present salvific transformation but also Hick's notion of pareschatology, that is, afterlife soul-making. This latter concept will be the topic of review in the next section.

\section{Hick’s Pareschatology}

Hick’s pareschatology forms a major center of his theological contributions and also forms the special concept addressed by in this dissertation. I review my findings of 
pareschatology under four headings: anthropology, death, afterlife, and pareschatology as a product of pluralism.

\section{Anthropology}

Hick’s anthropology serves as a prerequisite to the understanding of his pareschatology, because it deals with the possibility of human existence after death. Though arguing that man is created in the image of God, Hick's man is not a completed creature as described in Gen 1 and 2. Rather Hick applies the evolutionary principle to man's creation and adopts Irenaean anthropology. This means that humans remain in the process of being created finally into God's likeness. Thus, Hick claims that humans are involved in person-making in this life and in future lives, if necessary, until God's likeness is fully realized.

\section{Death}

On the basis of his Irenaean anthropology, Hick presents a unconventional understanding of death, as discussed in his Death and Eternal Life, which is integral to his understanding of pareschatology. The whole approach on the issue of death in Death and Eternal Life is global in nature. This attempt of doing a global theology of death is an example of putting his religious pluralism into practice. In doing so, in order to deal with apparent conflicts and contradicting views of death among the world religions, Hick distinguishes religious claims into two classes, one central, the other marginal. While the former is a matter of true or false, the latter is a matter of mythology.

Furthermore, applying Irenaean anthropology, Hick views death as a necessary part of man's existence of acquiring the likeness of God, rather than a divine punishment for sin. Thus, the moment of death is not understood as a moment of eternal judgment, 
but as a moment of transition to a higher level of existence, which opens the discussion of pareschatology. This new idea of death leads Hick to the discussion of the possibility of an afterlife which is the central issue of the general agenda of his pareschatology.

\section{Afterlife}

Hick suggests three possible options regarding afterlife: the materialist view of non-afterlife, the Western notions of heaven or hell, and the Eastern concept of reincarnation. Hick indicates that the latter two are useful options to be considered.

Though acknowledging that eschatologies from East and West are mutually exclusive, Hick argues that, nevertheless, they point to some reality beyond themselves. Hick supports the Eastern model of afterlife, which suggests a series of several afterlives, because the concept offers a response to the present life situation about which Hick claims that one short life is not enough for a complete transformation of humanity.

In regard to the possibility of an afterlife, applying a moral argument, Hick argues that it would be only fair if there is afterlife or afterlives in which earthly injustices or acts of unfairness are remedied. In response to this need Hick articulates an afterlife soulmaking process which represents his pareschatology.

\section{Pareschatology as a Product of Pluralsim}

Hick differentiates his pareschatological model from conventional eschatologies in the sense that the former is less remote and may be less incommensurate with the present life than the latter. After considering three major possible options such as Price's psychological survival hypothesis, his own version of Christian resurrection as replica theory, and Eastern reincarnation, Hick finally accepts the latter two models from East and West. Though he acknowledges that they are two mutually exclusive models, one 
suggesting only one life before final salvation and the other model suggesting many lives after death before the final human state, Hick finds something in common which renders their coexistence as a possible model. Hick contends that the two models seem to be mutually exclusive to each other, yet they agree, for instance, in their view that a human being is "a psycho-physical unity," which can be said to live again as an embodied being. In this fashion, Hick argues that while his notion of resurrection and the Eastern notion of reincarnation are superficially different, they are essentially in agreement.

As a result, combining eschatologies from East and West, Hick articulates his own model of “many lives in many different worlds” before the final perfection of humanity as his solution for conflicting views of different eschatologies. This account shows how Hick's pareschatology is a product of his pluralism.

\section{Criticisms of Hick’s Pareschatology}

I have discovered seven aspects integral or related to pareschatology which are open to a total of twenty criticisms by correspondence and coherence theories of truth. The seven aspects regarding pareschatology include: methodology, the Real, anthropology, death, afterlife, soul-making, and universal salvation.

\section{Principles of Method: Two Criticisms}

Two coherence criticisms can be noted regarding Hick’s principles of method. In his discussion of a global theology of death in relationship to pareschatology, Hick employs the following two principles of method: suggest possibilities rather than certainties, and be open to all data. I refer to Hick’s first methological principle as the "possibilities only" principle, and to the second methodological principle as the "all data" principle. 
The first criticism deals with Hick’s “possibilities only” principle. I find that Hick could have followed this principle much more closely than he does. For example, concerning the first principle, as the dissertation shows, Hick in effect suggests that his pareschatology is not leading us completely in a "wrong” direction but in the "right" direction. A right direction seems more like a clear and certain direction than a possible one. This circumstance seems to exclude other directions as possible directions, thereby transforming Hick’s own pareschatological direction into a theological construct that could more appropriately be called a certainty than a possibility.

In addition, in Death and Eternal Life, the way Hick sorts out eschatological options into two accounts, excluding some as less probable, and including others as more probable, seems to be crossing the line drawn by his first principle. Thus, Hick seems to step over the line of his "possibilities only” principle in the actual development of his pareschatology.

The second criticism concerns the second principle, namely the "all data" principle, in which Hick also seems to show inconsistency in his discussion of pareschatological options. Rather than including all major religious views on pareschatology, Hick ends with two major options from East and West. For example, Hick's theology of death does not include discussions of the eschatologies from Chinese, African, or South American religions. Because Hick considers some but not all major eschatologies, his “all data” principle could be applied more consistently than apparent in Hick’s exposition of pareschatology.

\section{The Real: Two Criticisms}

The discussion of pareschatology in its relationship with the Real is necessary, because it is a crucial key to understanding Hick’s pluralism as a whole. Two 
correspondence concerns can be identified in this context. One, while Hick never is able to clearly spell out the identity of the Real because of its inaccessibility, his soteriological and eschatological concerns lead him to postulate the notion of the Real as the center of the universe of the faiths. While on the one hand, the mature Hick considers religious experience as "a cognitive response to the ultimate nature of reality," ${ }^{1}$ he also insists that the descriptive terms such as good or evil, loving or hating cannot be applied literally to "the unexperiencable reality that underlies that realm." ${ }^{2}$ If this is the case, Hick's proposal seems to represent a generalization of tentative imaginary scenarios about human responses to a postulated Real an sich. Hick’s model appears unable to move beyond epistemic equivocation about the Real an sich.

Two, Hick's attempt to move beyond his earlier theocentrism leads him, particularly in his Kantian orientation in which he distinguishes between nounmenon and phenonomenon, to adopt the language of “an ultimate transcendent reality, the Real,”3 which has no theistic color in it. However, on the other hand, whatever terminology he may adapt for the Real, it seems that Hick has a tendency to describe the Real with theistic elements by connecting the word "divine” with the theistically colored word “God” in his most recent book, Who or What Is God? And Other Investigations (2008). For example, he refers to "the ultimate light of the universal divine presence" which seems to imply a theistic presence. This does not seem to fully correspond with Hick’s own attempt to describe the Real in nontheistic and impersonal terms.

\footnotetext{
${ }^{1}$ Hick, A Christian Theology of Religions: The Rainbow of Faiths, 75.

${ }^{2}$ Hick, An Interpretation of Religion: Human Responses to the Transcendent, 350.

${ }^{3}$ Hick, Who or What Is God? And Other Interpretations, 11.
} 


\section{Anthropology: Three Criticisms}

Hick's understanding of man is an issue which is integral to his account of pareschatology. His anthropology raises three internal concerns. First, Hick’s idea that humans, on the one hand, may survive bodily death in disembodied form and, on the other hand, that humans are inseparable psycho-physical unities are two mutually exclusive notions that cannot at the same time correspond with reality.

A second internal difficulty arises from the fact that Hick connects the Real as creator with the biological evolution of humanity. While Hick seems to embrace a wholly naturalistic biological evolutionary theory of human origins, his own account of human origins does not correspond to a wholly naturalistically interpreted biological evolutionary theory. In Hick’s accounts, the Real works creatively and teleologically in the emergence of humans in the evolutionary process in which divine action is excluded in wholly naturalistic evolutionary theory.

Third, Hick’s account of the biological evolution of humanity raises a potential difficulty. Hick bases his anthropology on a nineteenth-century hypothesis that is becoming unconvincing in some scientific circles. If this orientation becomes widespread, Hick may find himself in a dilemma of being tied to a scientific theory which may be doomed to possible eventual obsolescence, and thus to incoherence unless Hick would be willing to change his views.

\section{Death: Three Criticisms}

In his discussion concerning the issue of death, Hick’s new perspective suggests that death represents a moment of transition to another higher existence. Three criticisms can be raised. One, from a correspondence point of view, we can note that though providing a very optimistic and positive notion of death inspired by Irenaean 
anthropology, in the real world there seems to be no corresponding fact that the real character of death is like that which is described by Hick. In this respect, correspondence theory uncovers a difficulty of correspondence verification in Hick's theory of death and pareschatology.

Two, Hick's theological view, that correctness or incorrectness in theology is not significant as long as these conflicting concepts form part of a religious totality, suggests to me that Hick believes that differences between the teachings of death among world religions appear not to be religiously critical. However, this view seems to be inconsistent with his own effort to develop what he considers to be a true hypothesis of death.

Three, because in Hick's account of death people move from one world to another thus enabling personal growth toward the Real, death is seen not only positively but as something desirable. However, the theories of death held by other major religious people groups declare otherwise. Therefore, if Hick is willing to be open to all possible data including the general negative experience of people toward death, it seems to be incoherent for Hick to effectively suggest that death should not be avoided and feared but embraced by everyone.

\section{Afterlife: Three Criticisms}

The notion of the Real as infinite love and goodness is terminus a quo of Hick's theology of the afterlife. In light of this starting point, the idea of eternal conscious torment in hell, adopted from a literal understanding of hell from Augustinian and Calvinistic ideas, which Hick strongly believes is incompatible with the perfect goodness of God, leads him to present his own account of the afterlife. While this morally based argument for intermediate afterlives providing sufficient opportunities for the final 
perfection of humanity seems to be a more attractive view than the idea of an eternal hell, three concerns involving correspondence and coherence can be identified.

First, since the afterlife is outside of our knowledge as Hick himself acknowledges, his speculation regarding the nature of the afterlife has no corresponding reality with which it can be compared, thus underscoring a verification limitation. For instance, an implication flowing from Hick's concept of afterlife that millions of people who have died in the past and who are now supposedly in the process of being perfected in other worlds cannot to be confirmed by being shown to correspond with reality.

Second, Hick's notion that in the afterlives people may have more opportunities for soul-making because this life is too short to experience moral and spiritual growth faces another correspondence limitation including a coherence difficulty. Because Hick acknowledges that some people do not progress but on the contrary regress in this life under the influence of God's salvific activity, and if Hick assumes that the strength of God's salvific influence is the same in this life as it is in the afterlives, on what compelling grounds can we expect Hick's claim, that those who "regress" in this life will be healed in the afterlife, will correspond to reality in the future? In other words, it seems inconsistent for Hick to claim that if the application of God's salvific action causes a person to regress in this life, then simply more application of the same salvific action will make this regressor perfect in the afterlife.

Third, Hick bases his criticism of hell upon the Calvinistic literalistic interpretation of the biblical teaching of hell. He does not apply his mythological interpretation principle to the Calvinistic understanding of hell as he does with other cosmological biblical texts, which could have saved him from several difficulties regarding hell as classically interpreted. This hermeneutical inconsistency serves as one 
factor which leads Hick to develop his pareschatology as the solution to the original theodicy issue.

\section{Soul-making: Three Criticisms}

According to Hick, this world is a realm in which a process of person-making is only begun for most of humanity. This means that more afterlives will follow after this world, as needed. In this process of soul-making, evil has a key function. Stressing the instrumental and positive value of evil, Hick claims that evils are needed and even necessary if the world is to function as a place of person-making for morally and spiritually immature humans. In so doing, Hick applies the idea of the traditional " $\mathrm{O}$ felix culpa" theology in his own way and claims that it is "the heart of Christian theodicy." Thus, according to Hick, in a way God needs sin, that is, evil is a necessary means to an end. Three concerns can be raised regarding the issue of soul-making in this regard.

One, does a good end justify evil means?

Two, the soul-making theology that necessitates the existence of evil seems to face the problem of internal consistency. The evil described by Hick does not seem to be compatible with Hick's conception of the infinite goodness of the Real. If, as Hick claims, a morally perfect, infinitely good, and powerful God must use evil instrumentally in soulmaking, it seems that God does so on pain of moral inconsistency.

Three, in this context, the question can be raised whether the Law of God, or any stated will of God itself, not evil, can sufficiently test free agents in an evil-free environment. If so, this renders evil instrumentally unnecessary for the soul-making

\footnotetext{
${ }^{4}$ Hick, Evil and the God of Love, 400.
} 
process. However, Hick’s mythological interpretation of Gen 1-3 forecloses the possibility of considering or adopting such a worldview.

\section{Universal Salvation: Four Criticisms}

The terminus ad quem of Hick's pareschatology is the actuality of universal salvation, the condition in which "all human life will . . . be saved."5 Four internal criticisms can be raised in regard to this notion of universal salvation.

One, Hick’s pareschatology leads to universal salvation in a real and practical sense. However, this result seems to place Hick's notion of universalism into the category of a certainty, and not only a possibility, and so stands in conflict with Hick's method of advancing only possibilities.

Two, Hick claims that in this world the whole life of some individuals represents a "regress" from the Real. Hick’s thought that some never progress toward the Real in this life, but regress, is in conflict with his idea of the inherent gravitation of our being toward the Real and that humans are naturally not alien toward their maker.

Three, if Hick’s Real is infinitely good, and also humans are created as naturally gravitating toward the Real, Hick does not provide an answer as to why, for some, it takes nearly an infinite time to come to the salvific relationship with the Real. Hick’s notion of an almost infinite duration of afterlives for some humans, and that these

${ }^{5}$ Hick, Death and Eternal Life, 259. As John M. Rist notes, "Hick is prepared to admit that there must be logical possibility that all men may not respond to God's desire for universal salvation, but claims that God will with His infinite resourcefulness be able to re-establish those who have consistently chosen vice in preference to virtue on the true path. This, Hick claims, is a practical certainty" (Rist, "Coherence and the God of Love," 100). For more about God's saving power and human freedom, see Hick, "Freedom and the Irenaean Theodicy Again,” 527; Kane, "Freedom and the Irenaean Theodicy," 249; Ward, "Freedom and the Irenaean Theodicy." 
humans are created as gravitating toward God, seems inconsistent with the efficaciousness of God’s love and omnipotence as characterized by Hick.

Four, in articulating the issue of universal salvation, Hick confronts the problem of human freedom. Does the Real overrule the will of rebellious human beings, so that all humanity will be saved? Hick’s argument in favor of universalism with the postulate of an intermediate state in the context of the theodicy problem, whether the intermediate state is short or almost infinitely long, is not coherent with the idea of genuine human freedom. In order for universal salvation to be accomplished, and assuming that the human mind can by free choices become hardened against the Real, the omnipotent God must overrule the will of hardened rebellious humans. This can be seen as a divine act of coercion. In other words, a good and omnipotent God, who wishes to save all humanity, must inevitably sooner or later coerce those who reject him constantly, thereby nullifying their freedom to choose him with their own will. In short, while Hick’s universalism seems to offer a desirable answer for the theodicy problem, yet as a result, it has an internal incoherency problem with human freedom.

\section{Conclusions}

Before drawing my conclusions, I wish to articulate my appreciation of Hick as a philosopher of religion. From my research for this dissertation I have observed that Hick’s pluralism, particularly his pareschatology, has been the result of Hick’s own honest struggle concerning the questions of human existence, such as unfairness, injustice, and suffering. I laud his effort to find theodical answers for life problems not only with his academic expertise, but also with his spiritual and social dimensions of life as a whole. As a true lover of wisdom and as one who shows a real search for the truth, Hick tries to be open to all possible data available. As one with a Christian background, Hick shows 
bravery by moving beyond conventional thinking on certain theological issues. I admire his temerity in standing for his views in face of other people's severe criticisms from both liberal and conservative sides, and from both Christian and non-Christian circles. This encourages me to stand for my own Christian view of biblical truths in the face of this irreligious world. I turn now to the conclusions of the dissertation.

It has been my purpose in this dissertation to address and critically evaluate the external correspondency and internal consistency of Hick's pareschatology, which in turn may form the basis for a critical evaluation of his religious pluralism as a whole.

Regarding pareschatology, as discussed in the summary of findings in this chapter and in detail in chapter 5, Hick's pareschatology is open to various criticisms when judged by correspondence and coherence theories of truth. From my research of pareschatology, I have discovered and present reasons which back twenty criticisms of Hick's concept of pareschatology. Based upon these twenty criticisms stated above in the concluding chapter, the first general conclusion of my dissertation is that Hick's notion of pareschatology does not show sufficient internal coherence and, also, it is not fully coherent with his pluralistic model of world religions. The second general conclusion is that there is lack of external correspondence with the noumenal Real and with the phenomenal pareschatological manifestations of religious experiences in the particular religions. As a result, questions may be raised whether his pareschatological model can be regarded as a convincing theological philosophical scientific construct.

These considerations also have important implications for Hick's religious pluralism, which lead to the final conclusion of my dissertation. I find Hick's religious pluralism as a whole to be weakened by the problematic condition of his pareschatology. This whole circumstance can be compared with a building with several columns 
supporting the entire structure. If one foundational column—Hick's pareschatology—is problematic, the whole building-Hick's religious pluralism per se-is sooner or later open to collapse.

In closing the dissertation, as one standing in the Seventh-day Adventist theological community, I have gained from my study of Hick's theology of world religions some theological insights which are not conventional Christian concepts. For example, I appreciate Hick's understanding and rejection of hell which is different from the traditional Christian view. I have been encouraged and benefited by Hick’s insight of the human being as a psycho-physical unity rather than as two separable entities. Thus, in Hick’s religious, academic, and social struggles concerning human existence, there are areas where we can share the same burdens and further develop our theological understanding.

\section{Some Suggestions for Further Study}

Having been involved in focused research regarding Hick’s religious pluralism in general and his pareschatolical model in particular, I have found three areas that have drawn my attention to possible further study. One, a comparative project could be done on Hick's soteriology in relationship to the various aspects of the traditional central Christian concept of grace. Two, regarding Hick’s understanding of man as a psychophysical unity, a research project could study the relationship between Hick's understanding in this regard, with the recent "embodiment movement" as exemplified by Nancey Murphy's book Whatever Happened to the Soul? Scientific and Theological 
Portraits of Human Nature ${ }^{6}$ Three, a comparative study could be undertaken regarding Hick's notion of hell with biblical and the Seventh-day Adventist understanding of the concept of hell. Such further research holds promise of fruitful advancement of the theological understandings of these issues.

${ }^{6}$ Nancey Murphy, Warren S. Brown, and H. Newton Malony, eds., Whatever Happened to the Soul? Scientific and Theological Portraits of Human Nature (Güttingen: Vandenhoeck \& Ruprecht, 1998). 


\section{BIBLIOGRAPHY}

Abe, Masao. “God and Absolute Nothingness.” In God, Truth and Reality: Essays in Honour of John Hick, edited by Arvind Sharma, 33-45. New York: St. Martin's, 1993.

Adams, Marilyn M. “Hell and the God of Justice.” Religious Studies 11, no. 4 (Dec. 1975): 433-447.

Almond, Philip. “John Hick’s Copernican Revolution.” Theology 86, no. 709 (Jan. 1983): 36-41.

Alston, William P. "Religious Diversity and Perceptual Knowledge of God.” In The Philosophical Challenge of Religious Diversity, edited by Philip L. Quinn and Kevin Meeker, 193-207. New York: Oxford University Press, 2000.

Angeles, Peter A. “Coherence Theory of Truth.” Dictionary of Philosophy. Edited by Peter A. Angeles. New York: Barnes \& Noble Books, 1981, 297-298.

. “Correspondence Theory of Truth.” Dictionary of Philosophy. Edited by Peter A. Angeles. New York: Barnes \& Noble Books, 1981. 298.

. "John Hick and the Human Response to Transcendent Reality.” Dialogue \& Alliance 5, no. 2 (Sum. 1991): 43-51.

Badham, Roger A. “Redeeming the Fall: Hick’s Schleiermacher Versus Niebuhr's Kierkegaard.” The Journal of Religion 78, no. 4 (Oct. 1998): 547-570.

Bage, M., Lesslie Newbigin, and Church Growth Research Centre McGavran Institute (Madras, India). Many Other Ways? Questions of Religious Pluralism. New Delhi [India]: Ispck, 1992.

Baillie, Donald. God Was in Christ: An Essay on Incarnation and Atonement. New York: C. Scribner's Sons, 1948.

Baldwin, John T. “Introduction.” In Creation, Catastrophe, and Calvary, ed. John T. Baldwin. Hagerstown, MD: Review and Herald, 2000.

Barbour, Ian G. When Science Meets Religion. New York: HarperCollins, 2000. 
Basinger, David. "Hick's Religious Pluralism and 'Reformed Epistemology': A Middle Ground.” In The Philosophical Challenge of Religious Diversity, edited by Philip L. Quinn and Kevin Meeker, 161-171. New York: Oxford University Press, 2000.

Bellotti, Tony. Does Kant's Theory of Knowledge Lead to Solipsism? http://www.philosophypathways.com/essays/bellotti3.html, 2006. Accessed March 21, 2008.

Benjamin, A. Cornelius. "Coherence Theory of Truth.” Dictionary of Philosophy. Edited by Dagobert D. Runes, 74. Savage, MD: Littlefield, Adams Quality Paperbacks, 1983.

Bennett, Gaymon, Martinez J. Hewlett, Ted Peters, and Robert J. Russell, eds. The Evolution of Evil. Göttingen: Vandenhoeck \& Ruprecht, 2008.

Black, Max. "Correspondence Theory of Truth.” Dictionary of Philosophy. Edited by Dagobert D. Runes. Savage, MD: Littlefield, Adams Quality Paperbacks, 1983. 84

Blackburn, Simon. "Coherence Theory of Truth.” The Oxford Dictionary of Philosophy. Edited by Simon Blackburn. New York: Oxford University Press, 1996. 67. . "Correspondence Theory of Truth." The Oxford Dictionary of Philosophy. Edited by Simon Blackburn. New York: Oxford University Press, 1996. 84-85.

Blanshard, Brand. The Nature of Thought. 2 vols. New York: Macmillan, 1941.

Braaten, Carl E. "The Problem of the Absoluteness of Christianity.” Interpretation 40, no. 4 (Oct. 1986): 341-353.

Brannigan, Michael. "Problems of Religious Pluralism.” Cross Currents 36, no. 2 (1986): 242-244.

Buis, Harry. Review of Death and Eternal Life, by John Hick. Reformed Review 49 (Win. 1995-1996): 139.

Byrne, Peter. "Disputed Questions in Theology and the Philosophy of Religion.” Religious Studies 31, no. 3 (1995): 399-400.

Calvin, Jean. The Institutes of Christian Religion. Edited by Tony Lane and Hilary Osborne. Grand Rapids, MI: Baker Book House, 1987.

Canale, Fernando. Basic Elements of Christian Theology: Scripture Replacing Tradition. Berrien Springs, MI: Andrews University Lithotech, 2005. 
Cheetham, David. John Hick: A Critical Introduction and Reflection. Idershot: Ashgate, 2003.

Clarke, Peter B., and Peter Byrne. Religion Defined and Explained. New York: St. Martin's, 1993.

Clark-Soles, Jaime. Death and the Afterlife in the New Testament. New York: T \& T Clark, 2006.

Darwin, Charles. Origin of Species. New York: P. F. Collier \& Son, 1909.

Davis, Stephen T. “Comment on John Hick.” In Concepts of the Ultimate, edited by Linda J. Tessier, 163-164. New York: St. Martin’s, 1989.

Dawe, Donald G. “The End of the Silent Consensus.” Interpretation 32, no. 1 (Jan. 1978): 93-95.

D’Costa, Gavin. “Christian Theology and Other Faiths.” In Companion Encyclopedia of Theology. Edited by Peter Byrne and Leslie Houlden. New York: Routledge, 1995. 291-313.

. "John Hick and Religious Pluralism." Problems in the Philosophy of Religion: Critical Studies of the Work of John Hick, edited by Harold Hewitt. New York: St. Martin’s 1991.

. John Hick's Theology of Religions: A Critical Evaluation. Lanham, MD: University Press of America, 1987.

. Review of The Metaphor of God Incarnate: Christology in a Pluralistic Age, by John Hick. Religious Studies 31(1995): 136-138.

. "The Impossibility of a Pluralist View of Religions.” Religious Studies 32, no. 2 (1996): 223-232.

. "The New Missionary: John Hick and Religious Plurality." International Bulletin of Missionary Research 15, no. 2 (Apr. 1991): 66-69.

, ed. Christian Uniqueness Reconsidered. Maryknoll, NY: Orbis Books, 2004.

de Silva, Lynn A. The Problem of the Self in Buddhism and Christianity. New York: Barnes \& Nobles, 1979.

Dean, Thomas. Religious Pluralism and Truth: Essays on Cross-Cultural Philosophy of Religion. New York: State University of New York Press, 1995. 
Dembski, William A. "Introduction: The Myths of Darwinism.” In Uncommon Dissent, edited by William A. Dembski, xviii-xxxvii. Wilmington, DE: ISI Books, 2004.

Dembski, William A., and James M. Kushiner, eds. Signs of Intelligence: Understanding Intelligent Design. Grand Rapids, MI: Brazos Press, 2001.

Dilley, Frank B. “Resurrection and the 'Replica Objection’.” Religious Studies 19, no. 4 (Dec. 1983): 459-474.

Draper, John W. History of the Conflict between Science and Religion. New York: Appleton, 1874.

Duncan-Jones, Austin. “Man’s Mortality.” Analysis 28, no. 3 (1968): 86.

Dupré, Louis. Review of Death and Eternal Life, by John Hick. The Journal of Religion 58 (Apr. 1978): 217-219.

Eddy, Paul "John Hick’s Pluralist Philosophy of World Religions: An Exposition and Response.” Ph.D. diss., Marquette University, 1999.

"Religious Pluralism and the Divine: Another Look at John Hick’s NeoKantian Proposal.” Religious Studies 30, no. 4 (Dec. 1994): 467-478.

. "John Hick and the Historical Jesus." The Convergence of Theology, edited by Daniel Kendall and Stephen T. Davis. New York: Paulist Press, 2001.

Eitel, Keith E. “'The Way': Christ's Uniqueness and Its Bearing on Modern Missions.” Criswell Theological Review 4, no. 2 (Spr. 1990): 279-293.

Elder, Gregory P. Chronic Vigour: Darwin, Anglicans, Catholics, and the Development of a Doctrine of Providential Evolution. Lanham, MD: University Press of America, 1996.

"Ezekiel.” Seventh-day Adventist Bible Commentary. Edited by Francis D. Nichol. Washington, DC: Review and Herald, 1978.

Ferre, Nels Fredrick S. Christ and the Christian. New York: Harper, 1958.

Firestone, Chris L. “Kant and Religion: Conflict or Compromise?” Religious Studies 35, no. 2 (June 1999): 151-171.

Flew, Antony. "Coherence Theory of Truth.” A Dictionary of Philosophy. Edited by Antony Flew. New York: St. Martin’s, 1984. 66.

. "Correspondence Theory of Truth.” A Dictionary of Philosophy. Edited by Antony Flew. New York: St. Martin’s, 1984. 76-77. 
Forrester, Duncan. "Professor Hick and the Universe of Faiths.” Scottish Journal of Theology 29 (Feb. 1976): 65-72.

Forward, Martin. "The Rainbow of Faiths: Critical Dialogues on Religious Pluralism.” Expository Times 107, no. 7 (1996): 222.

Geach, Peter. Providence and Evil. Cambridge: Cambridge University Press, 1977.

Geivett, R. Douglas. Evil and the Evidence for God: The Challenge of John Hick's Theodicy. Philadelphia: PA: Temple University Press, 1993.

Gillis, Chester. A Question of Final Belief: John Hick's Pluralistic Theory of Salvation. New York: St. Martin’s, 1989.

. Review of Disputed Questions in Theology and the Philosophy of Religion, by John Hick. Theological Studies 54 (1993): 778.

Gooch, Paul W. "On Disembodied Resurrected Persons: A Study in the Logic of Christian Eschatology.” Religious Studies 17, no. 2 (June 1981): 199-213.

Goulder, Michael, and John Hick. Why Believe in God? London: SCM, 1983.

Grant, Colin. "The Threat and Prospect in Religious Pluralism.” The Ecumenical Review (Jan. 1989): 50-63.

Graves, Thomas H. "A Critique of John Hick’s Theodicy from an African Perspective.” Perspectives in Religious Studies 18, no. 1 (Spr. 1991): 23-38.

Gray, Tony. "The Nature of Hell: Reflections on the Debate between Conditionalism and the Traditional View of Hell.” In Eschatology in the Bible and Theology: Evangelical Essays at the Dawn of a New Millennium, edited by Kent E. Brower and Mark W. Elliott, 231-242. Downers Grove, IL: InterVarsity Press, 1997.

Green, Garrett. Review of An Interpretation of Religion: Human Responses to the Transcendent, by John Hick. Theology Today 46 (1990): 461-462.

Green, Michael, ed. The Truth of God Incarnate. London: Hodder \& Stoughton, 1977.

Gustafson, James M. Review of Evil and the God of Love, by John Hick. Union Seminary Quarterly Review 22 (1967): 182-184.

Guthrie, Donald. New Testament Theology. Leicester: IVP, 1981.

Hartt, Julian Norris. Review of Evil and the God of Love, by John Hick. Theology Today 24 (1967): 112-115. 
Hasel, Gerhard F. “The "Days” of Creation in Genesis 1: Literal "Days” or Figurative “Periods/Epochs” of Time?” In Creation, Catasrophe, and Calvary, edited by John T. Baldwin. Hagerstown, MD: Review and Herald, 2000.

Hebblethwaite, Brian. “John Hick and the Question of Truth in Religion.” In God, Truth and Reality, edited by Arvind Sharma. New York: St. Martin’s, 1993.

Heim, S. Mark. “The Pluralistic Hypothesis, Realism, and Post-Eschatology.” Religious Studies 28, no. 2 (Jan. 1992): 207-219.

Helm, Paul. "Universalism and the Threat of Hell.” Trinity Journal 4, no. 1 (Spr. 1983): 35-43.

Hick, John. “Afterword.” In Evil and the Evidence for God: The Challenge of John Hick's Theodicy, edited by R. Douglas Geivett, 229-237. Philadelphia: PA: Temple University Press, 1993.

. Arguments for the Existence of God. New York: Herder and Herder, 1971.

. Believable Christianity. http://www.johnhick.org.uk/article16.html, 2006. Accessed February 7, 2008.

. Biology and the Soul. Cambridge: The Cambridge University Press, 1972.

. "Biology and the Soul.” In Language, Metaphsics, and Death, edited by John Donnelly. New York: Fordham University Press, 1978.

. The Center of Christianity. San Francisco: Harper \& Row, 1978.

. A Christian Theology of Religions: The Rainbow of Faiths. Louisville, KY: Westminster John Knox, 1995.

. Christianity at the Center. London: SCM, 1968.

. "Christology at the Cross Roads.” In Prospect for Theology, edited by F. G. Healey. London: James Nisbet, 1966.

. “The Christology of D. M. Baillie.” Scottish Journal of Theology 11, no. 1 (Mar. 1958): 1-12.

. "Coherence and the God of Love Again.” Journal of Theological Studies 24, no. 2 (Oct. 1973): 522-528.

. Death and Eternal Life. London: Collins, 1976. 
. Disputed Questions in Theology and the Philosophy of Religion. New Haven: Yale University Press, 1993.

. “Eschatological Verification Reconsidered.” Religious Studies 13, no. 2 (Jan. 1977): 189-202.

. Evil and the God of Love. London: Macmillan, 1966.

. Faith and Knowledge. 2nd ed. Ithaca, NY: Cornell University Press 1966.

. The Fifth Dimension: An Exploration of the Spiritual Realm. Oxford:

Oneworld, 1999.

. "Freedom and the Irenaean Theodicy Again." The Journal of Theological Studies 21 (Oct. 1970): 419-433.

. God and the Universe of Faiths: Essays in the Philosophy of Religion. New York: St. Martin’s, 1973.

. “God, Evil and Mystery.” Religious Studies 3 (Apr. 1968): 539-546.

. God Has Many Names. Philadelphia: Westminster, 1982.

. An Interpretation of Religion: Human Responses to the Transcendent. New Haven: Yale University Press, 1989.

. John Hick: An Autobiography. Oxford: Oneworld, 2002.

. John Hick: Philosopher of Religion and Theologian.

http://www.johnhick.org.uk/, 2007. Accessed September 24, 2007.

. "Letters to the Editors: Incarnation.” Theology 80, no. 673 (Jan. 1977): 204206.

. The Metaphor of God Incarnate: Christology in a Pluralistic Age. Louisville, TN: Westminster, 1993.

. The New Frontier of Religion and Science: Religious Experience,

Neuroscience and the Transcendent. New York: Palgrave MacMillan, 2006.

. "The New Map of the Universe of Faiths." In Contemporary Philosophy of Religion, edited by Steven M. Cahn and David Shatz, 278-290. New York: Oxford University Press, 1982. 
. "The Non-Absoluteness of Christianity.” In The Myth of Christian

Uniqueness: Toward a Pluralistic Theology of Religions, edited by John Hick and Paul F. Knitter, 2005.

. "Pluralism and the Reality of the Transcendent." In Theologians in Transition, edited by James M. Wall, 60-66. New York: Crossroad, 1981.

. “The Philosophy of World Religions.” Scottish Journal of Theology 37, no. 2 (1984): 229-236.

. Philosophy of Religion. 4th ed. Englewood Cliffs, NJ: Prentice Hall, 1990.

. “A Pluralist View.” In More Than One Way? edited by Dennis L. Okholm and Timothy R. Phillips, 27-92. Grand Rapids, MI: Zondervan, 1995.

. "The Problem of Evil in First and Last Things.” The Journal of Theological Studies 19, no. 1 (Apr. 1968): 591-602.

. Problems of Religious Pluralism. New York: St. Martin’s, 1985.

. "The Real and Its Personae and Impersonae.” In Concepts of the Ultimate, edited by Linda J. Tessier, 143-158. New York: St. Martin’s, 1989.

. "Religious Pluralism and Absolute Claims.” In Religious Pluralism, edited by Leroy S. Rouner. Notre Dame, IN: University of Notre Dame Press, 1984.

. "Religious Pluralism and the Rationality of Religious Belief.” Faith and Philosophy 10, no. 2 (1993): 242-249.

. "The Reconstruction of Christian Belief for Today and Tomorrow: 1." Theology 73, no. 603 (Aug. 1970): 339-345.

. "The Reconstruction of Christian Belief for Today and Tomorrow: 2." Theology 73, no. 603 (Sept. 1970): 399-405.

. "A Remonstrance in Concluding." In Jesus in History and Myth, edited by R. Joseph Hoffmann and Gerald A. Larue. New York: Prometheus Books, 1986.

. "Response.” In Concepts of the Ultimate, edited by Linda J. Tessier, 171-176. New York: St. Martin’s, 1989.

. “Resurrection Worlds and Bodies.” Mind 82, no. 327 (July 1973): 409-412.

. Review of God, Pain and Evil, by George A. Buttrick. Theology Today 23 (1967): 583-584. 
. Review of The Freedom of the Will, by Austin Farrer. Theology Today. 17 (1960): 268-270.

. "Straightening the Record: Some Response to Critics.” Modern Theology 6, no. 2 (Jan. 1991): 187-195.

. Science and Religion. http://www.johnhick.org.uk/article5.html, 2002.

Accessed February 4, 2008.

. “Theology and Verification.” Theology Today 17, no. 1 (Apr. 1960): 12-31.

. What Does the Bible Really Say? http://www.johnhick.org.uk/articles13, html, 2005. Accessed February 5, 2008.

. Who or What Is God? And Other Investigations. London: SCM Press, 2008

Hick, John, ed. The Myth of God Incarnate. London: SCM, 1977.

Hick, John, and Paul F. Knitter, eds. The Myth of Christian Uniqueness: Toward a Pluralistic Theology of Religions. Maryknoll, NY: Orbis Books, 1987.

Horwich, Paul. “Truth.” The Cambridge Dictionary of Philosophy. Edited by Robert Audi. Cambridge; New York: Cambridge University Press, 1999. 929-931.

Hospital, Clifford G. "The Contribution of Keshub Chunder Sen toward a Global and Inductive Christology.” Journal of Ecumenical Studies 19, no. 1 (Win. 1982): 117

Huang, Yong. "Religious Pluralism and Interfaith Dialogue: Beyond Universalism and Particularism.” International Journal for Philosophy of Religion 37, no. 3 (June 1995): 127-144.

Hughes, Richard. “Bereavement and Pareschatology.” Encounter 43, no. 4 (Aut. 1982): 361-376.

Hull, David L. "Darwinism.” The Cambridge Dictionary of Philosophy. Edited by Robert Audi. New York: Cambridge University Press, 2006. 204-206

Irenaeus. Against Herecies. Ante-Nicene Fathers. Edited by A. Robert and J. Donaldson. Vol. 1. Grand Rapids, MI: Eerdmans, 1956.

Kane, G. Stanley. "Freedom and the Irenaean Theodicy.” The Journal of Theological Studies 20, no. 1 (Apr. 1969): 249-254.

. "The Failure of Soul-Making Theodicy.” International Journal for Philosophy of Religion 6 (Spr. 1975): 1-22. 
Kant, Immanuel. Critique of Pure Reason. London: Dent \& Sons, 1959.

Kärkkäinen, Veli-Matti. An Introduction to the Theology of Religions. Downers Grove, IL: InterVarsity, 2003.

Kaufman, Gordon D. God-Mystery-Diversity: Christian Theology in a Pluralistic World. Minneapolis: Fortress, 1996.

Kirkham, Richard L. “Coherence Theory of Truth.” Routledge Encyclopedia of Philosophy. Edited by Edward Craig. London; New York: Routledge, 1998. 9: 470-472.

. “Correspondence Theory of Truth.” Routledge Encyclopedia of Philosophy. Edited by Edward Graig. New York: Routhledge, 1998. 9.

Knitter, Paul. “Theocentric Christology.” Theology Today 40, no. 2 (July 1983): 130_ 149. . Theologies of Religions. Maryknoll, NY: Orbis Books, 2004.

Kvanvig, Jonathan L. The Problem of Hell. New York: Oxford University Press, 1993.

La Due, William J. The Trinity Guide to Eschatology. New York: Continuum, 2004.

Lampe, Geoffrey. God as Spirit: The Bampton Lectures. Oxford: Clarendon Press, 1976.

Léon-Dufour, Xavier. Life and Death in the New Testament: The Teachings of Jesus and Paul. New York: Harper \& Row, 1979.

Lerner, Berel Dov. “Interfering with Divinely Imposed Suffering.” Religious Studies 36, no. 1 (Mar. 2000): 95-102.

Lyden, John C. "Why Only 'One’ Divine Reality? A Critique of Religious 'Pluralism'.” Dialogue \& Alliance 8, no. 1 (Spr./Sum. 1994): 60-74.

Marias, Julian. History of Philosophy. New York: Dover Publications, 1967.

Mathis, Terry R. “The Place of Eschatological Verification in John Hick’s System of Thought.” Ph.D. diss., Claremont Graduate University, 1984.

McCready, Douglas. “The Disintegration of John Hick’s Christology.” Journal of the Evangelical Theological Socieity 39, no. 2 (June 1996): 257-270.

Meacock, Heather. An Anthropological Approach to Theology. New York: University Press of America, 2000. 
Merrigan, Terrence. “The Image of the Word.” In Newman and the Word, edited by Terrence Merrigan and Ian T. Ker. Grand Rapids, MI: Eerdmans, 2000.

Mesle, C. Robert. “The Problem of Genuine Evil: A Critique of John Hick's Theodicy.” The Journal of Religion 66, no. 4 (Oct. 1968): 412-430.

. "Suffering, Meaning, and the Welfare of Children: What Do Theodicies Do?" American Journal of Theology \& Philosophy 25, no. 3 (Sept. 2004): 247-264.

Mesle, C. Robert, and John Hick. John Hick's Theodicy: A Process Humanist Critique. New York: St. Martin’s, 1991.

"Metempsychosis.” The Oxford Dictionary of the Christian Church. Edited by F. L. Cross. New York: Oxford University Press, 1958.

Ministrial Association, General Conference of Seventh-day Adventists. Seventh-day Adventists Believe . . . : A Biblical Exposition of 27 Fundamental Doctrines. Hagerstown, MD: Review and Herald, 1988.

Moore, LeRoy. Review of Death and Eternal Life, by John Hick. Journal of the American Academy of Religion 46 (Mar. 1978): 90.

Moyers, Bill D., and Derek Davis. Genesis and the Millennium: An Essay on Religious Pluralism in the Twenty-First Century. Waco, TX: J.M. Dawson Institute of Church-State Studies Baylor University, 2000.

Mozley, John K. The Impassibility of God. Cambridge: University Press, 1926.

Murphy, Nancey, Warren S. Brown, and H. Newton Malony, eds. Whatever Happened to the Soul? Scientific and Theological Portraits of Human Nature. Güttingen:

Vandenhoeck \& Ruprecht, 1998.

Nah, David S. “A Critical Evaluation of John Hick’s Theology of Religious Pluralism.” Ph.D. diss., Claremont Graduate University, 2005.

Netland, Harold A. Dissonant Vocies: Religious Pluralism and the Question of Truth. Grand Rapids, MI: Eerdmans, 1991.

. “Exclusivism, Tolerance, and Truth.” Evangelical Review of Theology 12, no. 3 (July 1988): 240-260.

Nielsen, Kai. “A Response to John Hick.” In Death and Afterlife, edited by Stephen T. Davis, 97-203. New York: St. Martin’s, 1989.

Olding, Alan. "Resurrection Bodies and Resurrection Worlds.” Mind 79, no. 316 (Oct. 1970): 584-585. 
Oppenheimer, Helen. Review of Death and Eternal Life, by John Hick. Theology 81 (May 1978): 208-210.

Pache, René. The Future Life. Chicago: Moody, 1962.

Pannenberg, Wolfhart. "Constructive and Critical Functions of Christian Eschatology.” Harvard Theological Review 77, no. 2 (1984): 119-139.

Panthanmackel, George. "Problem of Evil: Hick’s Sublimation of Plantinga.” Journal of Dharma 23, no. 2 (Apr.-June 1998): 250-265.

Perry, Michael. Review of Death and Eternal Life, by John Hick, Churchman 91 (July 1977): 266-268.

Pierard, Richard V. “Theological Liberalism.” Evangelical Dictionary of Theology. Edited by Walter A. Elwell. Grand Rapids, MI: Baker Academic, 2001. 682-686.

Pittenger, Norman. The Word Incarnate: A Study of the Doctrine of the Person of Christ. New York: Harper, 1959.

Plantinga, Alvin. God, Freedom, and Evil. Essays in Philosophy. Edited by Arthur C. Dante. London: George Allen \& Unwin, 1975.

Polkinghorne, John. Science and Theology: An Introduction. Minneapolis, MN: Fortress Press, 1998.

Price, Henry H. "Personal Survival and the Idea of Another World." In Classical and Contemporary Readings in the Philosophy of Religion, edited by John Hick, 370393. Englewood Cliffs, NJ: Prentice-Hall, 1970.

Prior, A. A. “Correspondence Theory of Truth.” The Encyclopedia of Philosophy. Edited by Paul Edwards. New York: The Macmillan Company \& The Free Press, 1967. 2: 223-232.

Puccetti, Roland. "The Loving God: Some Observations on John Hick's Evil and the God of Love.” Religious Studies 2 (Apr. 1967): 255-268.

Race, Alan. Christians and Religious Pluralism: Patterns in the Christian Theology of Religions. 2nd ed. London: SCM, 1993.

Rahner, Karl. "Christianity and Other Religions.” In Christianity and Other Religions, edited by John Hick and Brian Hebblethwaite. London: William Collins Sons, 1980.

Rice, Richard. Review of Death and Eternal Life, by John Hick. Andrews University Seminary Studies 17 (Aut. 1979): 216-218. 
Rist, John M. “Coherence and the God of Love.” Journal of Theological Studies 23, no. 1 (Apr. 1972): 95-105.

Robinson, John A. T. Review of The Myth of God Incarnate-The Truth of God Incarnate, by John Hick and Michael Green, Journal of Theology for Southern Africa 21 (Dec. 1977): 67-70.

Robison, Jay D. Life after Death? Christian Interpretation of Personal Eschatology. New York: Peter Lang, 1998.

Rose, Kenneth T. "Knowing the Real: John Hick on the Cognitivity of Religions and Religious Pluralism.” Ph.D. diss., Harvard University, 1992.

Roth, John K. “Reply: Can John Hick Say What He Said?” In Concepts of the Ultimate, edited by Linda J. Tessier, 159-162. New York: St. Martin’s, 1989.

Rowe, William L. “Religious Pluralism.” Religious Studies 35, no. 2 (June 1999): 139 150.

Rowell, Geoffrey. Hell and Victorians. New York: Oxford University Press, 1974.

Ruse, Michael. Darwin and Design: Does Evolution Have a Purpose? Cambridge, MA: Harvard University Press, 2003.

Russell, Bertrand. A History of Western Philosophy. New York: A Touchstone Book, 1972. . Logic and Knowledge. New York: Macmillan, 1964.

.The Problems of Philosophy. 35. Home University Library of Modern Knowledge. New York: Henry Holt and Company, n.d.

Russell, Robert J. “The Groaning of Creation.” In The Evolution of Evil, edited by Gaymon Bennett, Martinez J. Hewlett, Ted Peters, and Robert J. Russell. Göttingen: Vandenhoeck \& Puprecht, 2008.

Scheid, Edward G. "Scripture and Theology of the Religions: On the Theological Interpretation of Sacred Scripture in Christian Attitudes toward World Religions." Ph.D. diss., Duquesne University, 1992.

Schmitt, Keith R. Death and After-Life in the Theologies of Karl Barth and John Hick. Amsterdam Studies in Theology. Amsterdam: Rodopi, 1985.

Schrag, Calvin O. "Pluralism.” The Cambridge Dictionary of Philosophy. Edited by Robert Audi. New York: Cambridge University Press, 1999. 714. 
Scott, J. Julius. “Literalism.” Evangelical Dictionary of Theology. Edited by Walter A. Elwell. Grand Rapids, MI: Baker Academic, 2001. 694-695.

Seeman, Brad. "What If the Elephant Speaks? Kant’s Critique of Judgment and an Ubergang Problem in John Hick's Philosophy of Religious Pluralism.” International Journal for Philosophy of Religion 54, no. 3 (Dec. 2003): 157-174.

Segal, Alan F. Life after Death: A History of the Afterlife in the Religions of the West. New York: Doubleday, 2004.

Seymour, Charles. "Hell, Justice and Freedom.” International Journal for Philosophy of Religion 43, no. 2 (Apr. 1998): 69-86.

Shinn, Larry D. “Death and Eternal Life.” Religion in Life 46, no. 3 (Aut. 1977): 386388.

Smart, Ninian. “A Contemplation of Absolutes.” In God, Truth and Reality: Essays in Honour of John Hick, edited by Arvind Sharma, 176-188. New York: St. Martin’s, 1993.

Stevenson, Ian. Twenty Cases Suggestive of Reincarnation. Proceedings of the American Soceity for Psychical Research. New York: American Society for Psychical Research, 1966.

Stumpf, Samuel Enoch. Socrates to Sartre: A History of Philosophy. New York: McGraw-Hill, 1966.

Swinburne, Richard. Review of Death and Eternal Life, by John Hick. Religious Studies 13 (Spr. 1977): 355-357.

. “The Problem of Evil.” In Contemporary Philosophy of Religion, edited by Steven M. Cahn and David Shatz, 3-19. New York: Oxford University Press, 1982.

. “A Theodicy of Heaven and Hell.” In The Existence of God, edited by Alfred J. Freddoso. Notre Dame: University of Notre Dame Press, 1983.

Talbott, Thomas. “The Doctrine of Everlasting Punishment.” Faith and Philosophy 7, no. 1 (Jan. 1990): 19-42.

. “Punishment, Forgiveness, and Divine Justice.” Religious Studies 29, no. 2 (June 1993): 151-168.

Tavard, George H. “The Myth of God Incarnate.” Theological Studies 39, no. 1 (Mar. 1978): 163-166. 
Temple, William. Readings in St. John's Gospel. London: Macmillan, 1945.

Toulmin, Stephen. "The Historicization of Natural Science: Its Implications for Theology.” In Paradigm Change in Theology, edited by Hans Küng and David Tracy. New York: Crossroad, 1991.

Travis, Stephen H. “The Problem of Judgment.” Themelios 11, no. 2 (Jan. 1986): 52-27.

Trethowan, Illtyd. "Dr. Hick and the Problem of Evil.” The Journal of Theological Studies 18 (Oct. 1967): 407-416.

van der Leeuw, G. Religion in Essence and Manifestation. New York: Harper \& Row, 1963.

van Holten, Wilko. "Hell and the Goodness of God.” Religious Studies 35 (Mar. 1999): 37-55.

van Till, Howard J., Davis A. Young, and Clarence Menninga. Science Held Hostage: What's Wrong with Creation Science and Evolutionism. Downers Grove, IL: InterVarsity Press, 1988.

Wainwright, William J. Review of Death and Eternal Life, by John Hick. Anglican Theological Review 63 (July 1981): 344-346.

Walker, Daniel P. The Decline of Hell: Seventeenth-Century Discussions of Eternal Torment. Chicago: University of Chicago Press, 1964.

Ward, Keith. "Divine Ineffability." In God, Truth and Reality: Essays in Honour of John Hick, edited by Arvind Sharma, 210-220. New York: St. Martin’s, 1993.

. “Theistic Evolution.” In Debating Design, edited by William A. Dembski and Michael Ruse, 261-274. Cambridge: Cambridge University Press, 2004.

. "Freedom and the Irenaean Theodicy." The Journal of Theological Studies 20, no. 1 (Apr. 1969): 249-254.

Whaling, Frank, ed. The World's Religious Traditions. New York: Crossroad, 1986.

White, Andrew D. A History of the Warfare of Science with Theology in Christendom. 2 vols. New York: Appleton, 1896.

White, Alan R. “Coherence Theory of Truth.” The Encyclopedia of Philosophy. Edited by Paul Edwards. New York: Macmillan Company and The Free Press, 1967.

Woelfel, James W. Review of Death and Eternal Life, by John Hick. Dialog 16 (Aut. 1977): 308-309. 
Yandall, Woodfin. Review of Death and Eternal Life, by John Hick. Southwestern Journal of Theology 20 (Spr. 1978): 95.

Yates, John C. “Survival as Replication.” Sophia 27, no. 2 (July 1988): 2-9.

Young, Frances. “A Cloud of Witnesses.” In The Myth of God Incarnate, edited by John Hick and Michael Goulder, 13-47. London: SCM, 1977.

Young, Warren C. A Christian Approach to Philosophy. Twin Books Series. Grand Rapids, MI: Baker Book House, 1973. 